\title{
RACHEL PROCHOROFF
}

O patrimônio geológico de llhabela - SP: estratégias de geoconservação

Dissertação apresentada ao Instituto de Geociências da Universidade de São Paulo para obtenção do título de Mestre em Geologia.

Área de concentração: Mineralogia Experimental e Aplicada

Orientador: Maria da Glória Motta Garcia

São Paulo 
Ficha catalográfica preparada pelo Serviço de Biblioteca e Documentação do Instituto de Geociências da Universidade de São Paulo

Prochoroff, Rachel

Patrimônio geológico de Ilhabela-SP.: estratégias de geoconservação / Rachel Prochoroff.

-- São Paulo, 2014.

ex.: 176 p. : il.

Dissertação (Mestrado): IGc/USP

Orient.: Garcia, Maria da Glória Motta

1. Ilhabela-SP : Geoconservação 2. Geoturismo I. Título 
Aos meus muitos amigos, tutores e esteios de Aruanda 


\section{AGRADECIMENTOS}

À minha orientadora Prof ${ }^{\mathrm{a}} \mathrm{Dr}^{\mathrm{a}}$ Maria da Gloria Motta Garcia, por insistir, guiar, discutir, elogiar, empurrar e mais do que tudo, acreditar.

Ao CNPq por financiar meu estudo com a concessão da bolsa de mestrado.

À Pró-Reitoria de Pós-Graduação da USP e ao GeoHereditas por viabilizar minha presença na $X$ Reunión Nacional de la Comisión de Patrimonio Geológico da Sociedade Geologica da Espanha e o estágio junto ao Prof. Dr. José Bernardo Rodrigues Brilha, acompanhando as atividades de campo e acadêmicas do Mestrado em Patrimônio Geológico e Geoconservação da Universidade do Minho, de maio a agosto de 2013.

Aos meus incríveis amigos Fernando Spinelli, Joana Bohner, Pedro Simões, Deyna Pinho e Vinícius Ribau por acariciarem meu coração, já há tantos anos.

À colega de mestrado e amiga tão querida Priscila Lopes, ouvidos e coração sempre abertos para o apoio gigante em todos os momentos da Iniciação Científica e deste mestrado.

Ao Sidney Gouveia, amigo de longa data, que estendeu a mão com sua ajuda preciosa e todo o seu conhecimento vasto em SIG, solucionando meu problema com as imagens do Google Earth.

Aos colegas de departamento e programa de pós, Letícia Guimarães, Liza Polo, Tabata Hoeger, Marcelo Freimann e Eva K. Mori, pelas discussões importantes e pelos momentos de diversão inestimáveis.

Ao Prof. Dr. Gergely Szabó, por ter-me direcionado, em 2005, indicando a saída que me trouxe para onde estou hoje.

Ao Prof. Dr. Daniel Atêncio e ao Prof. Dr. Paulo C. F. Giannini, pela paciência e diligência em discutir minha pesquisa e pelos momentos de tranquilidade, que trouxeram à tona ideias extremamente valiosas.

Ao Prof. Renato de Moraes, pelo apoio e "punhos firmes" em momentos de decisões importantes.

À Gina G.M. Pimentel, do COSEAS, por estender a mão e empunhar um espelho em um momento crucial.

Aos funcionários do Instituto de Geociências, sempre prestativos e sorridentes, pelo carinho e pela inestimável ajuda todas as vezes que precisei. 
À Carol Marto e Paula Bolta, pelo acolhimento, carinho, força e forró, durante os períodos que passei em llhabela, e que se transformaram em amizade.

Aos funcionários do PElb, e, em especial, à gestora Joana F. Alves, Ivomar, Winny, Bicudo, Walter, por tornarem possível minha estada na sede do parque e por me guiaram às cachoeiras e trilhas da ilha, contando histórias às vezes divertidíssimas e às vezes muito tristes de seus anos na luta pela preservação ambiental.

À Niède Guidon, modelo e inspiração, que tornou possível meu acesso a uma perspectiva totalmente nova.

Ao Prof. Dr. José B. R. Brilha, da Universidade do Minho, que, esbanjando bom humor, muitas vezes me trouxe de volta ao chão, quando as asas da imaginação ameaçavam colocar-me em órbita.

A meus pais, Felippe e Maria Helena, e aos meus irmãos, Thais e Guilherme, por sempre me exortarem a dar o melhor de mim.

Ao Big Guy Upstairs, que sabia de tudo, muito antes de eu mesma cogitar, e abriu as portas, janelas, caminhos, meu coração e minha mente. 
"Creio haver lido em Tácito que as éguas iberas concebiam pelo vento; se não foi nele, foi noutro autor antigo, que entendeu guardar essa crendice nos seus livros. Neste particular, a minha imaginação era uma grande égua ibera; a menor brisa lhe dava um potro, que saía logo cavalo de Alexandre (...)."

Machado de Assis

(Dom Casmurro) 


\section{RESUMO}

PROCHOROFF, R. O patrimônio geológico de Ilhabela - SP: estratégias de geoconservação. 2014. 175p. Dissertação (Mestrado) - Instituto de Geociências, Universidade de São Paulo, São Paulo, 2014.

A ilha de São Sebastião, situada no litoral norte do estado de São Paulo, abriga o município de llhabela, estância balneária famosa por suas praias, trilhas e cachoeiras e o Parque Estadual de Ilhabela (PElb). A visitação e utilização deste local sem estratégias de conservação e manutenção podem se revelar danosas em médio e longo prazo. Por isso, é importante proceder ao inventário e à proteção de sua geodiversidade. Norteado pelo conceito apresentado pelo Serviço Geológico do Brasil (CPRM, 2006), este trabalho realizou o levantamento do patrimônio geológico de valor científico. Localizada no Terreno Serra do Mar, as rochas da ilha ilustram eventos geológicos importantes da região. Porém, o acesso aos afloramentos pode ser difícil, pois grande porcentagem do terreno apresenta desníveis intensos e é coberta por mata atlântica. Por isso, foi necessário percorrer trilhas ou acessar os locais pelo costão rochoso. $O$ framework utilizado foi a história geológica da região costeira do estado, no contexto da evolução do Supercontinente Gondwana. Nesta categoria temática foram selecionados nove geossítios: Pedra do Sino, Pico do Baepi, Cachoeira do Gato, Praia da Figueira, Praia de Enchovas, Buraco do Cação, Diques da Ponta da Sela, Gabros Estratiformes e Praia do Portinho. Para a quantificação, foram utilizados os métodos de Brilha (2005) e da plataforma Geossit, desenvolvido pelo Serviço Geológico do Brasil (CPRM), que combina parâmetros e quesitos dos métodos de Brilha (2005) e Garcia-Cortés \& Carcavilla Urquí (2009). Os resultados foram comparados e discutiu-se seu uso na área de estudo, concluindose que é necessária a extensa aplicação do Geossit com contínuo trabalho de desenvolvimento de alternativas e parâmetros que contemplem integralmente a grande diversidade de ambientes brasileiros. Ao final, são sugeridas iniciativas de gestão e interpretação dos geossítios, como o desenvolvimento de sites, painéis e guias geológicos, de modo a valorizar a área e seu patrimônio geológico e incentivar o geoturismo para o desenvolvimento social. Os resultados deste trabalho fornecem dados acerca da relevância científica, da vulnerabilidade e das ameaças do patrimônio geológico de llhabela, revelam locais com necessidade de maiores pesquisas científicas, apontam destinos didáticos universitários, bem como oferecem subsídios para a implementação de iniciativas de gestão que valorizem e protejam a geodiversidade enquanto alavancam o desenvolvimento social da região.

Palavras-chave: Geoconservação, Geoturismo, llhabela, Litoral Norte de São Paulo, Patrimônio Geológico. 


\section{ABSTRACT}

PROCHOROFF, R. Geoheritage in Ilhabela - SP: strategies for geoconservation. 2014. 175p. Dissertação (Mestrado) - Instituto de Geociências, Universidade de São Paulo, São Paulo, 2014.

The Island of São Sebastião, on the northern coast of the state of São Paulo, comprises the city of Ilhabela, famous for its beaches, waterfalls and trails, and the State Park named after the city (PElb). The high-use rate of this place without conservation and management strategies may cause damage in the medium and long term. It's important that the inventory of its geodiversity be done and protection measures be taken. Under the light of the definition coined by the Geological Service of Brazil (CPRM, 2006), this work aimed at inventorying the island's geoheritage of scientific value. The rocks of Ilhabela, part of the Terreno Costeiro tectonic domain, illustrate important geological events of this portion of the continent. However, the access to the bedrocks is usually hard, since most of the island is covered with rain forest and slopes. To get to the rocks it was necessary to explore jungle trails and climb the coastal boulders. The places of geological interest were appointed using as framework the geological history of the state coastline, with focus on the evolution of the Gondwana supercontinent. Nine scientific geosites were selected: Pedra do Sino, Pico do Baepi, Cachoeira do Gato, Praia da Figueira, Praia de Enchovas, Buraco do Cação, Diques da Ponta da Sela, Gabros Estratiformes and Praia do Portinho. The quantification of the geosites was done using two methods: the one devised by Brilha (2005) and the one developed by the Geological Service of Brazil (CPRM), presented on their website as Geossit, and which was based on Brilha's (2005) and GarciaCortés \& Carcavilla Urquí 's (2009) methods. Results were compared and its application on the area of this study was discussed. It was possible to conclude that the extensive use of Geossit and the development of continuous changes to the alternatives and parameters are necessary so as to encompass the large diversity of the Brazilian environments. To conclude, ideas for the geosites management and interpretation - such as websites, panels and geoguides - are suggested, aiming at valuing the area and its geoheritage as well as encouraging geoturism for social development. Results of this work provide data on the scientific relevance of the geoheritage in Ilhabela, reveal places in need of deeper investigation, suggest places for college studies and offer ground on which the organs of government and society may base geoheritage management plans in order to value and protect the island's geodiversity as well as boost social development.

Keywords: Geoconservation, Geoheritage, Geotourism, Ilhabela, Northern Coast of São Paulo 


\section{ÍNDICE DE FIGURAS}

Figura 1.1 Localização da ilha de São Sebastião, no Litoral Norte de $\mathrm{SP}$

Figura 1.2 Seção do mapa do Estado de São Paulo representando o litoral norte e as principais cidades próximas a llhabela (GUIA GEOGRÁFICO, 2010)

Figura 2.1 Os limites de abrangência do PElb (11) e da APA Marinha Litoral Norte, setor Maembipe (13), (FUNDAÇÃO FLORESTAL, 2012)

Figura 2.2 O guaiamú (Cardissoma guanhumi Laitrelle - EOL, 2012), espécie típica do mangue, e o cururuá (Phyllomys thomasi - ICMBIO, 2012), endêmico: espécies que dependem da geodiversidade da llha de São Sebastião.

Figura 2.3.1a Províncias estruturais de Almeida et. al. (1977, apud Dantas, 1980)

Figura 2.3.1b Os orógenos que compõem a Província Mantiqueira e sua subdivisão em segmentos: Setentrional (Araçuaí), Central (Brasília Sul, Ribeira e Apiaí) e Meridional (Dom Feliciano e São Gabriel).(HEILBRON et al., 2004).

Figura 2.3.2 As entidades tectono-estratigráficas do estado de São

Paulo (CPRM, 2006)

Figura 2.4.2a O contexto da llha de São Sebastião no recorte do mapa da CPRM (Perrotta et al., 2005), que não contempla a geodiversidade da ilha

Figura 2.4.2b Mapa geológico da ilha de São Sebastião, por Hennies e Hasui (1977)

Figura 2.4.2c Recorte do Mapa Geológico do Estado de São Paulo mostrando a área da llha de São Sebastião (IPT, 1981) ....

Figura 2.4.2d Mapa geológico da llha de São Sebastião de Bellieni et al (1990)

Figura 3.5.3 Dentre todos os elementos da geodiversidade, somente aqueles que apresentam características que se sobressaem em valor cultural, educativo ou outro, são considerados patrimônio geológico. (PEREIRA, 2010). 
Figura 4.1 Localização pontual dos geossítios da llha de São Sebastião: Pedra do Sino, Pico do Baepi, Portinho, Gabros estratiformes, Diques da Ponta da Sela, Buraco do Cação, Praia de Enchovas, Praia da Figueira, Cachoeira do Gato... 42

Figura 4.1.1 Localização do geossítio Pedra do Sino na llha de São Sebastião.

Figura 4.1.2 Afloramento visto de dentro do restaurante. Os blocos são atingidos pelas ondas e parcialmente submersos quando a maré sobe

Figura 4.1.3 Os blocos que ficam mais tempo em contato com a água do mar apresentam caneluras mais pronunciadas e certa coloração rósea, que os difere dos blocos não alcançados pela água.

Figura 4.1.4a Alguns blocos maiores apresentam-se rachados. A vegetação aproveita o menor espaço que se abra para procurar luz, causando, com o tempo, uma separação ainda maior entre os dois pedaços (intemperismo biológico)

Figura 4.1.4b Alguns blocos apresentam arestas e pouco arredondamento; outros já se encontram bastante retrabalhados. No afloramento todo a diferença de dimensões entre os blocos é notável.

Figura 4.1.5 A prefeitura instalou duas passarelas que levam aos dois blocos mais sonoros do afloramento.

Figura 4.1.6a Em um momento de alta temporada, a visitação ao local é intensa. As pessoas sentem-se curiosas a respeito do som e das formas diferenciadas dos blocos e ficam um longo tempo tecendo hipóteses.

Figura 4.1.6b A marreta oferecida pelo restaurante passa de mão em mão. Todos ficam ávidos para martelar a rocha e produzir o som metálico

Figura 4.1.7a A principal Pedra do Sino, ao final da passarela. Pode-se observar que suas bordas estão lascadas devido aos golpes repetidos de marreta pelos turistas. 
Figura 4.1.7b Os turistas ficam empolgados com o som metálico e utilizam a marreta fornecida pelo restaurante para bater em outros blocos, a fim de investigar se eles também produzem som. Nesta foto, outro bloco do afloramento também foi lascado pelo processo.

Figura 4.2.1 O Pico do Baepi, no topo do maciço alcalino Serraria, ao norte da ilha. O pico apresenta duas lajes, sendo a sul, a mais alta, com $1048 \mathrm{~m}$ de altitude

Figura 4.2.2 O Pico do Baepi visto do ponto de início da trilha, ao final do dia. (Foto: Maria da Glória Motta Garcia).

Figura 4.2.3a A porção sul do canal de São Sebastião, avistado pela laje norte do Pico do Baepi. Ao longe, a silhueta da ilha de Alcatrazes (indicada pela seta). (Foto: Maria da Glória Motta Garcia).

Figura 4.2.3b A porção central do canal de São Sebastião e o porto, vistos da laje norte do Pico do Baepi. (Foto: Vanessa Mucivuna)

Figura 4.2.3c A porção norte do canal de São Sebastião, vista da laje norte do Pico do Baepi, com o litoral de Caraguatatuba ao fundo. (Foto: Maria da Glória Motta Garcia).

Figura 4.2.3d Em condições de excelente visibilidade, a área passível de ser avistada do mirante natural que é o Pico do Baepi ultrapassa $800 \mathrm{~km}^{2}$, de acordo com os cálculos de área efetuados através do Google Earth

Figura 4.2.4 Compartimentação fisiográfica de larte do litoral norte do estado de São Paulo (modificado de SOUZA, 2006)

Figura 4.2.5 Vista panorâmica das porções Sul, central e Norte do Canal de São Sebastião a partir da laje norte do Pico do Baepi. O mirante fornece um ótimo ponto de observação para o estudo de processos geomorfológicos associados ao litoral norte do estado de São Paulo. (Foto: Vanessa Mucivuna)

Figura 4.3.1 Localização da Cachoeira do Gato na llha de São Sebastião. 
Figura 4.3.2 A localização da Cachoeira do Gato em relação à Praia de Castelhanos.

Figura 4.3.3 O paredão da cachoeira se eleva por cerca de $50 \mathrm{~m}$ e a queda da água forma uma piscina natural que é atrativo turístico do local.....

Figura 4.3.4a A instalação de uma passarela pelo Parque Estadual facilita o acesso à água e a segurança dos turistas. 62

Figura 4.3.4b A declividade do terreno aumenta e a água segue seu caminho em direção ao oceano por entre blocos de grandes dimensões.

Figura 4.3.5 A rocha aflorada está degradada, devido à exposição contínua, ou já coberta por musgos que aceleram sua degradação por intemperismo biológico.

Figura 4.3.6a Remanescente de dique no paredão. O formato empresta o nome à cachoeira, já que os moradores locais enxergam nele as feições de um gato.

Figura 4.3.6b Outro remanescente de dique, desta vez no canto inferior esquerdo do paredão. Infere-se que os dois "restos" tenham sido parte constituinte do mesmo corpo intrusivo..... 63

Figura 4.4.1 Localização do ponto médio do geossítio Praia da Figueira, na llha de São Sebastião.

Figura 4.4.2 As Praias Vermelha e da Figueira em relação uma à outra. A distância em linha reta entre as duas é de aproximadamente $1.700 \mathrm{~m}$

Figura 4.4.3a A Praia da Figueira, uma faixa de cerca de $300 \mathrm{~m}$ de areia com porções avermelhadas devido à grande concentração de granada (Foto: Christine Bourotte).

Figura 4.4.3b Areia da Praia da Figueira, cuja concentração de granada chega a cerca de $90 \%$ (Foto: Christine Bourotte). 66

Figura 4.4.4a Os cristais centimétricos de feldspatos no clorita-biotitagranada monzogranito que cerca a praia toda (Foto:

Christine Bourotte)

Figura 4.4.4 b Detalhe do granitoide que envolve toda a praia da Figueira, mostrando os cristais subcentimétricos de granada (Foto: Christine Bourotte). 
Figura 4.5.1 A localização do geossítio Praia de Enchovas na ilha de São Sebastião.

Figura 4.5.2 A Praia de Enchovas dista cerca de $2200 \mathrm{~m}$ em linha reta da Praia do Bonete. Por esta imagem aérea pode-se ver o alinhamento de blocos na direção NE/SW que delimita um dos lados da praia.

Figura 4.5.3 Praia de Enchovas vista em ponto alto da trilha de acesso, que sai da Praia do Bonete.

Figura 4.5.4 A alta concentração de minerais pesados opacos e semi opacos $(57 \%)$ conjugada a minerais transparentes de cores mais escuras, como a hornblenda marrom e a hornblenda verde, faz com que a areia tenha grandes porções com aparência bastante escura.

Figura 4.5.5 Zona de tormenta da Praia de Enchovas, coberta de seixos e blocos de tamanhos e tipos litológicos diversos.

Figura 4.5.6a Bloco de granito profirítico cortado por um veio de quartzo, de cerca de $35 \mathrm{~cm}$ em seu eixo longitudinal e arredondado pelo retrabalhamento das ondas na zona de tormenta.

Figura 4.5.6b Seixo de basalto bem retrabalhado, com $5 \mathrm{~cm} \times 11 \mathrm{~cm}$ de dimensão, apresentando cristais sub-centimétricos de plagioclásio. Indicado pela seta vermelha da escala, um cristal geminado.

Figura 4.5.7 Contato entre granito porfirítico e gabro, no ponto além do alinhamento de rochas que marca o final leste da Praia de Enchovas, já no início do costão rochoso. (Foto: Erick Mota).....

Figura 4.6.1 Localização do geossítio Buraco do Cação na llha de São Sebastião.

Figura 4.6.2. O Buraco do Cação visto do mar. A altura deste paredão é de aproximadamente $60 \mathrm{~m}$ e a separação entre as duas partes, no ponto mais alto, é de cerca de $5 \mathrm{~m}$.

Figura 4.6.3 A água do mar ficam azuis e claras ao pé do paredão, oxigenadas pelo movimento constante das ondas. 
Figura 4.6.4a Sobreposição do mapa geológico (IPT, 1981) sobre a imagem de satélite da llha de São Sebastião, com a localização da Praia da Fome e do Buraco do Cação. A observação do remanescente de dique no boqueirão da Praia da Fome, de orientação NE/SO, faz supor que o Buraco do Cação tenha sido formado pelo mesmo processo

Figura 4.6.4b O boqueirão da Praia da Fome com o dique remanescente, ambos orientados na direção NE/SO, como a maioria dos diques principais da ilha.

Figura 4.6.5a Vista da parte superior do Buraco do Cação. A direção preferencial de fraturas, NE/SO, condiz com a dos outros sistemas de diques e fraturas da ilha. (Foto: Fernanda Palhares).

Figura 4.6.5b O Buraco do Cação, em sua interface com a água, é mais largo. As ondas que atingem a ilha são preferencialmente de sul e leste e este pode ser um dos motivos pelo qual o dique hipotético foi totalmente cominuído, sem sobrar vestígios. (Foto: Fernanda Palhares).

Figura 4.6.6a A disposição dos blocos no topo do Buraco do Cação sugere que a rocha era um bloco único, que fraturou em duas direções quase ortogonais entre si, por onde os agentes de intemperismo agiram.

Figura 4.5.6b A fratura da rocha segue preferencialmente direções quase ortogonais entre si, e o intemperismo molda blocos de rochas que se assemelham a cubos de arestas arredondadas. (Foto: Erick Mota)

Figura 4.6.7 As diferenças do intemperismo em rochas graníticas e nefelina sientíticas: A) No granito, a água se infiltra ao longo de fraturas de resfriamento magmático; B) na nefelina sienito, ocorre o case hardening, que protege 0 interior da rocha do intemperismo superficial. (MOTOKI et al, 2008)

Figura 4.6.8 Caneluras pronunciadas em blocos de rocha sienítica no bairro da Siriúba (esquerda) e na Praia do Jabaquara, no extremo norte da ilha (direita). 
Figura 4.7.1 A localização do geossítio Diques da Ponta da Sela na ilha de São Sebastião

Figura 4.7.2 Porção da rocha encaixante com indícios de milonitização ( esquerda) e dique pegmatítico félsico (direita). (Foto: Maria da Glória Motta Garcia).

Figura 4.7.3 Parte do costão de granito porfirítico, cortado pelos diques, visto pelo mar.

Figura 4.7.4 Desenho esquemático do afloramento modificado de Higa (2011) com todos os diques máficos. I: rocha encaixante dos diques. J: blocos de rocha não in situ. Diques em F1: A, B, D.. Diques em F4: C, E. F: F4. G: F1. H: F2

Figura 4.7.5 Contato retilíneo entre o dique a rocha encaixante (esquerda). À direita, feição de borda no dique (chifre), indica o fluxo magmático (para a esquerda, na foto) na ocasião em que o dique se instalou. (Foto: Maria da Glória Motta Garcia).

Figura 4.7.6 Estrias nas paredes do dique de lamprófiro, que indicam direção de movimento subhorizontal na direção N40. (Foto: Eliane Del Lama) O dique lamprófiro interrompe e desloca o dique de diabásio, como se pode ver na próxima figura.... 86

Figura 4.7.7 Os diques entrecortantes: neste ponto, o dique de diabásio é interrompido e deslocado pelo dique lamprófiro.

Figura 4.8.1 Localização do geossítio Gabros Estratiformes na ilha de São Sebastião.

Figura 4.8.2 O gabro estratiforme, com bandamentos félsicos e máficos, que podem indicar filter pressing na câmara magmática...... 91

Figura 4.8.3 Dique intrudindo dique, com contatos definidos e com texturas diferentes (o interno e mais novo, afanítico, e o externo e mais antigo, porfirítico) (Foto: Maria da Glória Motta Garcia).

Figura 4.8.4 Enclave gabróico autolítico de aparente predominância félsica na rocha encaixante, também gabro: o estudo destas relações pode revelar mais sobre a dinâmica magmática que se estabeleceu ao redor dos maciços alcalinos 
Figura 4.8.5 O crescimento de anfibólio acicular preenchendo textura vuggy no gabro

Figura 4.8.6 Na ponta sul do geossítio, o contato entre granito porfirítico, presente em várias partes da ilha, e o gabro

Figura 4.8.7 Localização de pontos de coleta das amostras IBL-03, IBL04 e IBL-28 de gabro investigadas por Augusto (2003) e próximas ao local proposto para este geossítio

Figura 4.9.1 Localização do geossítio Portinho, na llha de São Sebastião

Figura 4.9.2a $\mathrm{O}$ início do costão do Portinho visto de cima do afloramento de gnaisse bandado. A faixa de areia é coberta por blocos de rocha, o que faz com que a praia seja usada principalmente para pesca e mergulho e pouco por banhistas.

Figura 4.9.2 b Veios leucocráticos no gnaisse bandado, de espessura subcentimétrica a dezenas de centímetros 95

Figura 4.9.3 Camada leucogranito grosso, de cerca de $20 \mathrm{~cm}$ de espessura e concordante com o gnaisse, apresenta feldspatos subeuédricos e bem desenvolvidos e quartzo e muscovita em quantidade subordinada.

Figura 4.9.4 Ao fundo, parede de cerca de $10 \mathrm{~m}$ de largura: gnaisse bandado com intercalações de rochas calciossilicáticas....... 96

Figura 4.9.5 Dique máfico do afloramento, concordante com a foliação... 96

Figura 4.9.6 Rocha calciossilicatica com foliação de transposição no afloramento do Portinho.

Figura 4.9.7 A parede de gnaisse e rochas silicáticas, com os boudins indicados pelos círculos amarelos.

Figura 6.5.2 A sinalização utilizada para interpretação geológica no Geoparque da Costa Basca, que alia plaquetas nos locais (abaixo) com um código que remete às explicações em um guia (acima). As plaquetas têm cerca de $10 \mathrm{~cm}$ de lado e estão afixadas no solo. 
Figura 6.5.3a Vermiculita proveniente dos sedimentos do Lago Dourado. A presença do mineral em suspensão faz a água reluzir sob a luz do sol, incentivando o folclore de que haveria um tesouro enterrado nas redondezas. Escala: $1 \mathrm{~mm}$

Figura 6.5.6 Um pedaço de "chocolate de pirita" (dimensões: $3 \mathrm{~cm} \times 3$ $\mathrm{cm}$ aproximadamente), feito com chocolate e amêndoas (acima), imitando o mineral que até 1988 era extraído na Mina do Lousal, Portugal (abaixo)

Figura 6.6.1a Bloco de rocha localizado próximo ao início da passarela que leva aos blocos sonoros da Pedra do Sino, na Praia de Garapocaia e o restaurante Pedra do Sino, no fundo à esquerda.

Figura 6.6.1b Sugestão de painel para o geossítio Pedra do Sino 140 


\section{ÍNDICE DE TABELAS}

Tabela 3.4 As várias e mais influentes definições de geodiversidade desde 1995 (Modificado de NIKITINA, 2012) ..................... 34

Tabela 3.5.3 Os valores da geodiversidade, segundo Brilha (2005)........ 40

Tabela 5.2.1a Os parâmetros de quantificação no método de Brilha (2005), separados por critérios de valor intrínseco, uso potencial e necessidade de proteção dos geossítios.

Tabela 5.2.1b Exemplo de como são as alternativas em um parâmetro da quantificação do método de Brilha (2005) 105

Tabela 5.2.2a Os parâmetros e seus pesos correspondentes no método de Garcia-Cortés \& Carcavilla Urqui (2009)

Tabela 5.2.2b Exemplo de alternativas e valores numéricos possíveis para o parâmetro "Raridade" no critério de valor intrínseco de um LIG no método de Garcia-Cortés \& Carcavilla Urqui (2009)

Tabela 5.2.2c Os parâmetros para a quantificação da vulnerabilidade de um geossítio e seus respectivos pesos, no método de Garcia-Cortés \& Carcavilla Urqui (2009).

Tabela 5.2.2d Cálculo da prioridade de proteção de um geossítio em sua vertente científica $(P P c)$, didática $(P P d)$, turística $(P P t)$ e global (PP) e o significado dos números obtidos, no método de Garcia-Cortés \& Carcavilla Urqui (2009)

Tabela 5.2.3a Parâmetros para quantificação da vulnerabilidade no Geossit (CPRM) 109

Tabela 5.2.3b Parâmetros para quantificação das características intrínsecas de um geossítio no Geossit (CPRM).

Tabela 5.2.3c Os parâmetros e seus pesos relativos para cálculo de Interesses científico, didático e turístico no sistema da plataforma Geossit (CPRM). 
Tabela 5.3.1a Resultados finais dos critérios A, B e C e posição no ranking final dos geossítios pela quantificação do método de Brilha (2005)

Tabela 5.3.1b Valores atribuídos a cada um dos parâmetros para a quantificação dos geossítios pelo método de Brilha (2005) 114

Tabela 5.3.2a Valores dos interesses científico (Ic), didático (Id), turístico (It) global (Ig), vulnerabilidade (V) e valor final da prioridade de proteção (PP) de cada geossítio, bem como sua posição na lista de prioridade de intervenção, calculados através do Geossit (CPRM)

Tabela 5.3.2b Cálculo da vulnerabilidade (V) dos geossítios de llhabela no Geossit (CPRM)

Tabela 5.3.2c Valores atribuídos aos parâmetros e cálculo final de A (características intrínsecas) dos geossítios no Geossit (CPRM)

Tabela 5.3.2d Valores atribuídos aos parâmetros e cálculo final de B (uso potencial) dos geossítios no Geossit (CPRM).

Tabela 5.3.2d Valores atribuídos aos parâmetros e cálculo final de C (necessidade de proteção) dos geossítios no Geossit (CPRM)

Tabela 5.3.2e Cálculo do interesse científico dos geossítios no Geossit.... 119

Tabela 5.3.2f Cálculo do interesse didático dos geossítios no Geossit...... 120

Tabela 5.3.2g Cálculo do interesse turístico dos geossítios no Geossit...... 121

Tabela 5.3.2h Cálculo do interesse global (lg), a partir da média aritmética das médias dos interesses didático (Id), científico (Ic) e turístico (It) no Geossit.

Tabela 7.2 Os geossítios de llhabela, os valores de cada um, quais processos ou eventos geológicos importantes ilustram e as eventuais características adicionais que agregam valor e interesse a eles. 


\section{ÍNDICE DE GRÁFICOS}

Gráfico 4.4.4 Composição da assembleia de minerais pesados na areia da Praia da Figueira (contagem em lâmina), com predominância de granada (ARAMAQUI, 2013).

Gráfico 7.3.3a Resultados da quantificação dos critérios A, características intrínsecas dos geossítios, no método de Brilha (2005), à esquerda e no Geossit, à direita.

Gráfico 7.3.3b Resultados da quantificação dos critérios B, uso potencial dos geossítios, no método de Brilha (2005), à esquerda e no Geossit, à direita.

Gráfico 7.3.3c Resultados da quantificação dos critérios C, necessidade de proteção dos geossítios, no método de Brilha (2005), à esquerda e no Geossit, à direita.

Gráfico 7.3.3d Resultados da quantificação de vulnerabilidade dos geossítios no Geossit.

Gráfico 7.3.3e Resultados da quantificação do interesse científico dos geossítios no Geossit

Gráfico 7.3.3f Resultados da quantificação do interesse didático dos geossítios no Geossit.

Gráfico 7.3.3g Resultados da quantificação do interesse turístico dos geossítios no Geossit..... 
SUMÁRIO

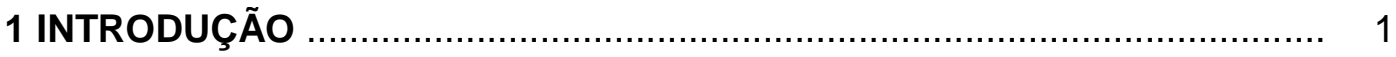

1.1 A IMPORTÂNCIA DE UM INVENTÁRIO DE ILHABELA.............. 2

1.2 LOCALIZAÇÃO DA ÁREA ................................................................. 4

1.3 METODOLOGIA........................................................................ 4

1.3.1 Inventário........................................................................ 5

1.3.2 Quantificação e classificação.................................................... 7

1.3.3 Gestão ...................................................................... 7

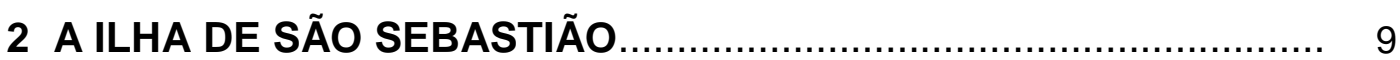

2.1 LOCALIZAÇÃO........................................................................... 9

2.2 - CARACTERÍSTICAS DA ILHA.................................................... 10

2.3 CONTEXTO GEOLÓGICO................................................. 11

2.3.1 A Província Mantiqueira ........................................ 11

2.3.2 O Orógeno Ribeira.................................................... 14

2.3.3 Terreno Serra do Mar (Domínio Costeiro).................... 17

2.4. A GEODIVERSIDADE DE ILHABELA.................................... 18

2.4.1 A geologia da ilha .............................................. 19

2.4.2 Mapas geológicos da ilha ....................................... 21

3 GEODIVERSIDADE E GEOCONSERVAÇÃO: CONCEITOS ........... 25

3.1 EM BUSCA DE EXPLICAÇÕES ............................................ 25

3.2 USUFRUTO DO HOMEM: UM EQUÍVOCO DE BASES HISTÓRICAS ANTIGAS...................................................... 26

3.3 A NECESSIDADE DE PRESERVAR .................................... 28

3.4 BIODIVERSIDADE VERSUS GEODIVERSIDADE.................. 30

3.5 PATRIMÔNIO GEOLÓGICO: QUANDO A GEODIVERSIDADE DEVE SER CONSERVADA ...................................................... 35

3.5.1 Geodiversidade ................................................. 35

3.5.2 Geoconservação ....................................................... 36

3.5.3 Patrimônio geológico........................................... 37 
4.1 GEOSSÍTIO PEDRA DO SINO............................................................ 43

4.2 GEOSSÍTIO PICO DO BAEPI............................................................ 50

4.3 GEOSSÍTIO CACHOEIRA DO GATO................................................... 58

4.4 GEOSSÍTIO PRAIA DA FIGUEIRA - AS AREIAS VERMELHAS........... 64

4.5 GEOSSÍTIO PRAIA DE ENCHOVAS - AS PEDRAS ROLADAS........... 68

4.6 GEOSSÍTIO BURACO DO CAÇÃO........................................................... 73

4.7 GEOSSÍTIO DIQUES DA PONTA DA SELA....................................... 82

4.8 GEOSSÍTIO GABROS ESTRATIFORMES............................................ 87

4.9 GEOSSÍTIO PRAIA DO PORTINHO................................................. 93

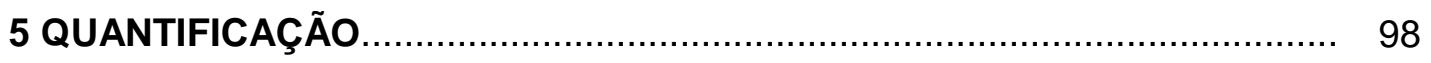

5.1 A IMPORTÂNCIA DA ESCOLHA DO MÉTODO...................................... 98

5.2 OS MÉTODOS UTILIZADOS PARA A QUANTIFICAÇÃO DO PATRIMÔNIO GEOLÓGICO DE ILHABELA................................................. 100

5.2.1 O método de Brilha (2005) ....................................................... 101

5.2.2 O método de Ángel Garcia-Cortés \& Luis Carcavilla Urquí (2009)

5.2.3 Geossit - o sistema do Serviço Geológico do Brasil

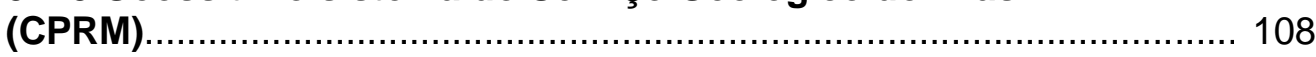

5.3 RESULTADOS DA QUANTIFICAÇÃO................................................... 113

5.3.1 Método de Brilha (2005)........................................................ 113

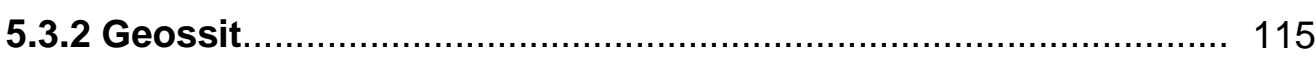

6 SUGESTÕES DE GESTÃO DO PATRIMÔNIO GEOLÓGICO DE

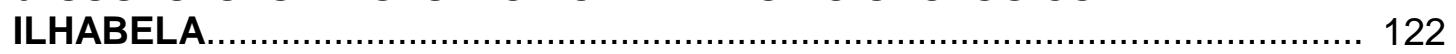

6.1 POR QUE PROCEDER À GESTÃO? ...................................................... 123

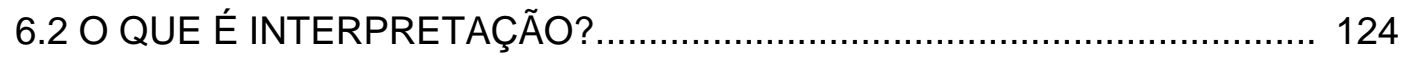

6.3 O QUE ESPERAR DAS INICIATIVAS DE GESTÃO? .............................. 127

6.4 QUEM SERÁ O RESPONSÁVEL? ....................................................... 130

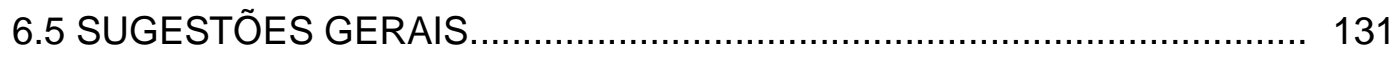

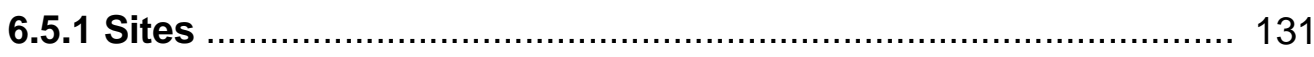

6.5.2 Guia geológico e roteiros geoturístico …………………........ 132

6.5.3 Capacitação de guias turísticos ………………………............. 134

6.5.4 Capacitação de educadores ………………………………..... 135 
6.5.6 Envolvimento dos setores comerciais: alimentação, hotelaria, artesanato

6.6 INTERVENÇÕES PONTUAIS NOS GEOSSÍTIOS ................................. 138

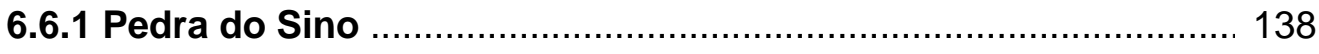

6.6.2 Pico do Baepi ...................................................................... 141

6.6.3 Cachoeira do Gato ................................................................. 142

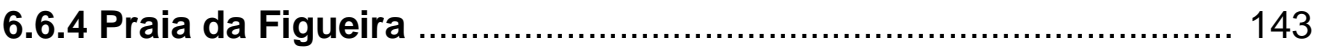

6.6.5 Praia de Enchovas ............................................................. 144

6.6.6 Buraco do Cação ...................................................................... 144

6.6.7 Diques da Ponta da Sela, Gabros Estratiformes e Praia do

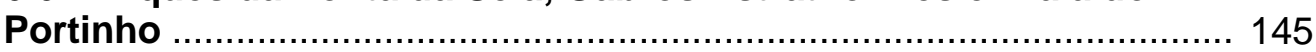

7 DISCUSSÃO E CONCLUSÕES ........................................................... 148

7.1 METODOLOGIA DO INVENTÁRIO ................................................. 148

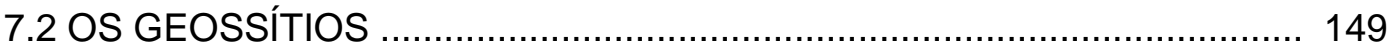

7.3 O PROCESSO DE QUANTIFICAÇÃO ........................................... 151

7.3.1 Método de Brilha (2005) ...................................................... 151

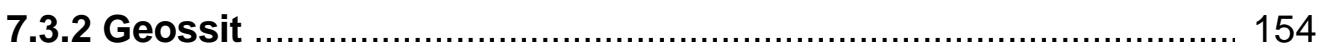

7.3.3 Resultados das quantificações ........................................... 156

7.3.4 Conclusões sobre a quantificação .......................................... 160

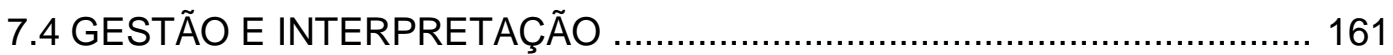

7.5 CONCLUSÕES GERAIS E PANORAMA FUTURO ............................. 162

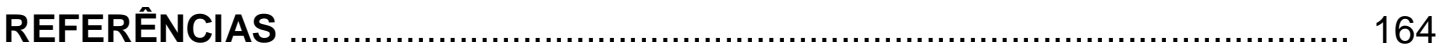





\section{INTRODUÇÃO}

Discussões sobre a preservação da geodiversidade têm conquistado espaço cada vez maior no Brasil, seguindo a tendência mundial, que teve seu início na Europa, na década de 1990. Países como Portugal e Espanha já concluíram seus inventários nacionais de patrimônio geológico, possuem leis de respaldo e proteção a este patrimônio e há anos se dedicam à geoconservação, através da educação e de projetos de geoparques bem estabelecidos.

Em 2013, Portugal estabeleceu seu quarto geoparque, Terras de Cavaleiros. No mesmo país, Arouca, Naturtejo e Açores são geoparques membros da Rede Global de Geoparques, GGN, sob os auspícios da UNESCO (GGN, 2013). A Espanha aprovou em 2007 a lei nacional do Patrimônio Natural e da Biodiversidade, que inclui a proteção ao patrimônio geológico (CARCAVILLA URQUI; MARTINEZ; VALSERO, 2007) e atualmente o país tem oito geoparques em seu território, também membros da GGN.

Em consonância com esta tendência, desde 1997 o Brasil vem cadastrando sítios de interesse geológico e paleobiológico através da SIGEP (Comissão Brasileira de Sítios Geológicos e Paleobiológicos). O projeto, iniciado em 1996 pelo Departamento Nacional de Produção Mineral (DNPM), conta com a colaboração de inúmeros órgãos, como a ABEQUA (Associação Brasileira para Estudos do Quaternário), IPHAN (Instituto do Patrimônio Histórico e Artístico Nacional) e o Serviço Geológico do Brasil-CPRM, entre outros (SIGEP, 2013).

Pesquisadores de diversas universidades brasileiras estão desenvolvendo projetos de inventário do patrimônio geológico de suas localidades. O Serviço Geológico do Brasil delineia, neste instante, uma plataforma online para descrição e quantificação de geossítios e lugares de interesse geológico de nosso território (GEOSSIT, 2013). Em 2012, o mesmo órgão lançou um compêndio de 33 sugestões de projetos de geoparques, cujos inventários foram feitos por geólogos da própria CPRM (SCHOBBENHAUS E SILVA, 2012), sendo também responsável pela iniciativa, ainda germinando, de um Fórum de Geoparques Brasileiros.

É consenso entre os pesquisadores brasileiros da área de Geociências a necessidade de aprofundar as pesquisas no assunto, para conhecer, valorizar e preservar o patrimônio geológico do nosso país. 


\subsection{A IMPORTÂNCIA DE UM INVENTÁRIO DE ILHABELA}

No litoral Norte do Estado de São Paulo localiza-se a ilha que abriga o município de Ilhabela (Fig.1). Conta-se que os primeiros exploradores portugueses aportaram em Maembipe, em 1502, no dia de São Sebastião, assim denominando a ilha na ocasião (ILHABELA, 2012; LUPO \& BORTOLUSSO, 2012; SIMÕES, 2005). Conhecida popularmente pela alcunha que também é o nome da cidade que a contém, Ilhabela se tornou, a partir dos anos de 1980, um dos destinos preferidos para o turismo dos habitantes das regiões próximas, especialmente de classes sociais mais abastadas, bem como de estrangeiros que tomam a balsa para apreciar suas praias e se aventurar pelas trilhas no meio da Mata Atlântica (MERLO, 2005).

Nem o sol forte do verão, tampouco a importunação dos insetos, muitas vezes dolorosa, desanima os visitantes que assomam à ilha na alta temporada. Ilhabela faz jus, indubitavelmente, ao nome que recebeu.

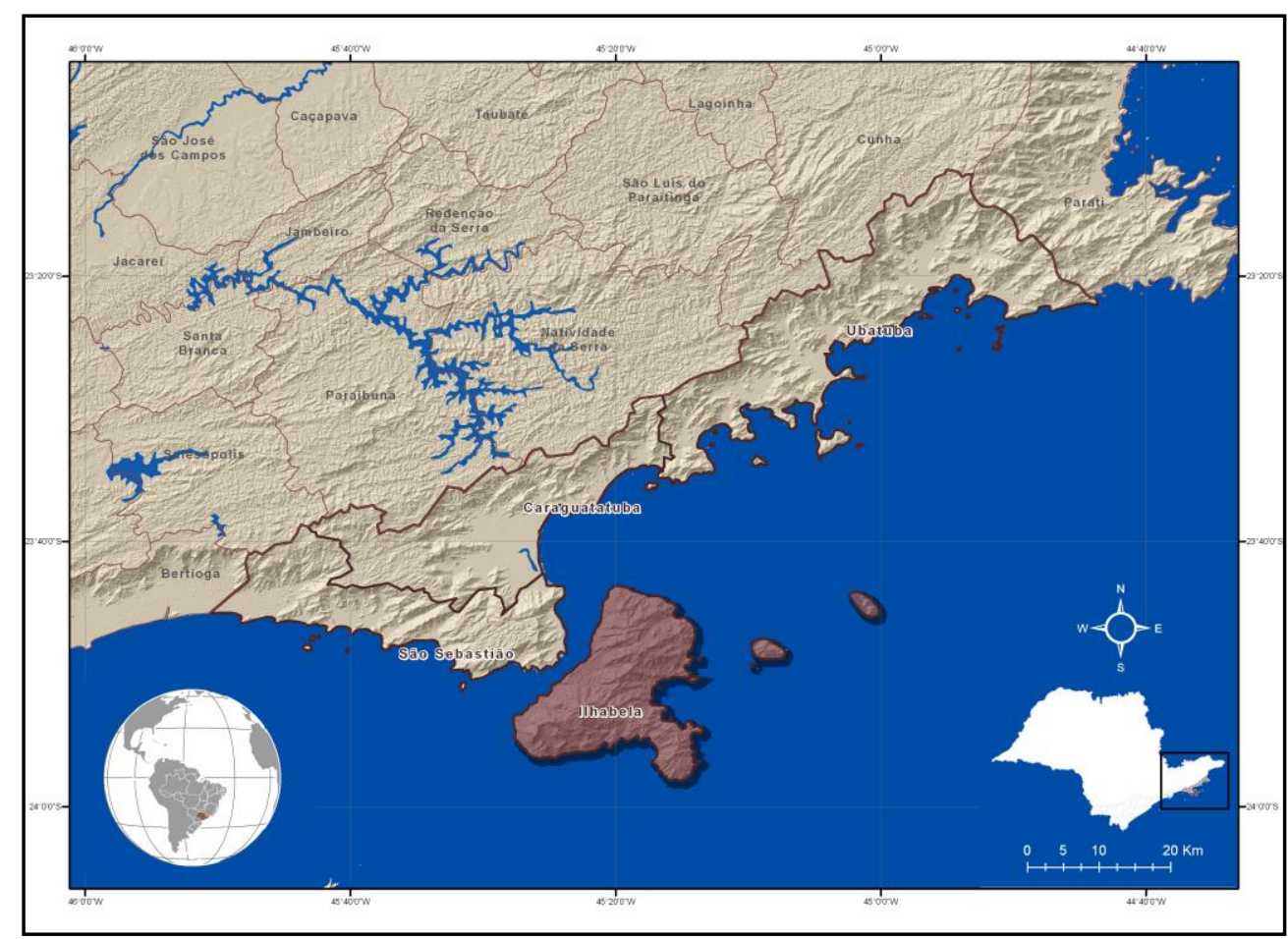

Figura 1.1 - Localização da ilha de São Sebastião, no Litoral Norte de SP.

O que os visitantes, em sua quase totalidade, não atinam, é que debaixo da vegetação exuberante, escondem-se tipos litológicos de alto valor para a história geológica desta região. Aflorando ao longo dos costões rochosos e também em 
pontos específicos no interior, que não raro, sempre foram de difícil acesso (HENNIES \& HASUI, 1977; LUPO \& BORTOLUSSO, 2012) as rochas que formam a ilha testemunham ao menos três momentos diferentes da história do planeta e comprovam sua dinâmica:

i) o embasamento é composto majoritariamente de gnaisses em vários graus de migmatização, tal qual grande parte do litoral no Complexo Costeiro e data do Pré-Cambriano; a direção preferencial dos diques e fraturas nas rochas, a NE-SW, afere a formação do supercontinente Gondwana;

ii) grandes stocks alcalinos mesozóicos rasgaram este embasamento e deram origem às feições geomorfológicas que hoje sustentam mirantes naturais de mais de 1000m de altitude, como o Pico do Baepi;

iii) enxames de diques máficos e lamprófiros adornaram a porção central e setentrional da ilha, na reativação das falhas, quando da gestação do Oceano Atlântico Sul, (DIAS NETO, 2001; GARDA, 1995; HASUI \& SADOWSKI, 1976), podendo ser comparados a registros de "um exame de ultrassom 3D daquele feto marinho". Além disso, não somente Ilhabela, mas também Búzios e Vitória, ilhas participantes do arquipélago, são parte da Província Alcalina da Serra do Mar, atestando o segundo e o terceiro estágios da Reativação Wealdeniana de Almeida (1967).

A diversidade da região e a preocupação em proteger e garantir a longevidade destas feições motiva um detalhado trabalho de inventário dos principais pontos de interesse geológico que poderão sagrar-se "patrimônio", devido ao alto valor científico, educacional e social. Para tanto, é necessário proceder ao levantamento destes geossítios, inicialmente. Porém, como aquilatar o que interessa, geologicamente, em vista das noções mais atuais de geodiversidade? É necessário avaliar o contexto interdisciplinarmente, mantendo em vista que um afloramento conversa com a biota, com as condições atmosféricas, com os turistas e com os habitantes locais e suas manifestações culturais (BRILHA, 2005).

A ilha é considerada estância balneária e por isso recebe milhares de turistas todos os anos. A visitação e utilização de suas praias e trilhas, sem estratégias de conservação e manutenção apropriadas, no que concerne à geodiversidade, promete ser danoso em médio e longo prazo. Por isso, torna-se premente aferir, quantificar e valorar a geodiversidade da Ilha de São Sebastião, para que seja 
conservada e possa continuar: (i) a ilustrar, elucidar ou ser objeto de pesquisas e estudos, tanto em nível superior, quanto nos ciclos fundamentais e médio do ensino escolar e (ii) a promover a manutenção do valor geoturístico da ilha, que fundamenta grande parte dos processos econômicos e sociais locais.

\subsection{LOCALIZAÇÃO DA ÁREA}

A cidade de Ilhabela está localizada na ilha de São Sebastião, no litoral norte do estado de São Paulo. Faz limite a oeste com o Canal de São Sebastião e a leste com o Oceano Atlântico e está próxima das cidades de São Sebastião, Ubatuba e Caraguatatuba. Dista cerca de $210 \mathrm{~km}$ da capital do estado e $440 \mathrm{~km}$ da cidade do Rio de Janeiro e seu acesso se dá, a partir da cidade de São Sebastião, por travessia de balsa pelo canal (Fig. 1.2).

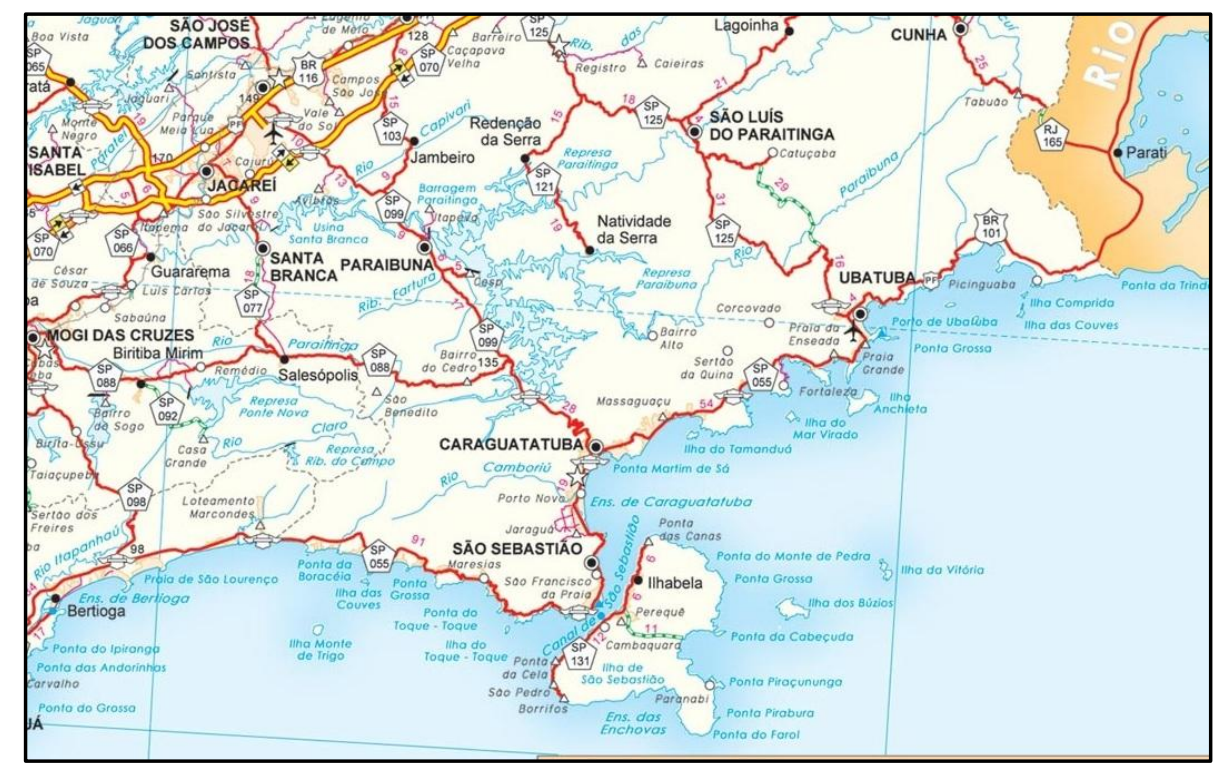

Figura 1.2 - Seção do mapa do Estado de São Paulo representando o litoral norte e as principais cidades próximas a llhabela (GUIA GEOGRÀFICO, 2010)

\subsection{METODOLOGIA}

O inventário do patrimônio geológico de um local é o primeiro passo dos cinco (inventário, quantificação, classificação, conservação, valorização e divulgação) que, 
segundo Brilha (2005), compõem as estratégias de geoconservação. Neste trabalho foram feitas as primeiras três fases, inventário, quantificação e classificação, baseando-se essencialmente na metodologia de Brilha e, quando necessário, foram feitas modificações ou inserções, conforme exposto a seguir.

\subsubsection{Inventário}

Um inventário da geodiversidade de um determinado local deve ser iniciado com a consulta à bibliografia (teses, artigos e dissertações) que versem sobre a área. Concomitantemente, a verificação destas informações e outras, adicionais, são feitas com profissionais (professores, pesquisadores e geólogos de campo) que tenham estudado ou trabalhado no local a ser inventariado. Estas consultas permitem ao pesquisador (ou grupo de pesquisadores) que efetua o inventário a determinação de pontos onde a geologia e a geomorfologia podem apresentar características que justifiquem a delimitação de geossítios.

Para a averiguação destas informações, é necessário proceder-se a estudos de campo, percorrendo os locais previamente delimitados e outros, que vão sendo descobertos ou apontados por moradores locais, turistas e visitantes. Com isso, um trabalho de campo de inventário às vezes requer várias visitas à mesma área, quando possível, para averiguação de pontos que, inúmeras vezes, não foram descritos na bibliografia.

No presente trabalho de mestrado, não sendo a bibliografia profícua, foi necessária a consulta a professores que estudam ou haviam estudado as rochas da ilha, a moradores locais e aos guardas do Parque Estadual de Ilhabela, os quais, muito prestativos, possibilitaram a aferição de parte da geodiversidade da ilha, auxiliando-nos no acesso aos locais remotos, especialmente em casos onde se depende de conhecimentos das trilhas locais.

A área estudada apresenta relevo bastante variado, com picos de altitudes de mais de 1000 m, vales, cachoeiras e rios caudalosos em épocas de chuvas contínuas (verão), cuja travessia é perigosa. Além disso, sua maior parte é coberta por vegetação e, por isso, muitas vezes as rochas estão parcialmente ou totalmente inacessíveis, exceto em locais desmatados e através dos costões rochosos. Desse 
modo, foi necessário percorrer trilhas já abertas para o levantamento da geodiversidade local, ou galgar os matacões onde o costão prometia exibir litologia de interesse e o acesso era de alguma forma possível (GARCIA et al. ${ }^{1}$, 2014).

Os trabalhos de campo foram feitos visando à descrição de pontos de interesse geológico, com subsequente caracterização das rochas e dos processos geológicos e geomorfológicos que contemplam os locais visitados. No total, foram feitas duas viagens de campo, de uma semana cada, onde, além de percorrer algumas trilhas na mata atlântica, os pontos já levantados na bibliografia e nas comunicações orais foram visitados e descritos.

Devido ao clima predominantemente úmido, localização próxima ao oceano e relevo acidentado, as rochas em evidência apresentam-se bastante intemperizadas. Quando necessário e possível, foram amostradas, tomando-se o cuidado para que este procedimento não interferisse na beleza ou apresentação do local. Para minimizar o impacto visual, as amostras de rochas foram retiradas de locais mais afastados das trilhas ou em lados dos matacões que não fossem diretamente observáveis pelo transeunte corriqueiro.

Foram feitas seções delgadas de algumas destas amostras, que atualmente são objeto de estudo do projeto de iniciação científica executado pelo aluno Fabio Pileggi. O projeto, intitulado "Banco de Dados Petrográficos dos Geossítios do Litoral Norte do Estado de São Paulo", é orientado pela Prof ${ }^{\mathrm{a}}$ Dr $^{\mathrm{a}}$ Eliane Aparecida Del Lama e forneceu alguns dados citados nesta dissertação.

As trilhas percorridas foram "trackeadas" para posterior confecção de mapas e guias geoturísticos que pudessem auxiliar na manutenção e proteção da geodiversidade local. Além disso, a localização dos pontos de campo, os dados coletados em cada ponto e o traçado das trilhas percorridas foram incorporados ao banco de dados do Núcleo de Apoio à Pesquisa em Patrimônio Geológico e Geoturismo (GeoHereditas) e serão oportunamente utilizados em outros projetos da área.

1 GARCIA, M.G.M; MARTINS, L.; DEL LAMA, E.A.; BOUROTTE, C. O inventário do patrimônio geológico da região costeira do estado de São Paulo: base metodológica, adaptações e considerações. Trabalho aceito para o $47^{\circ}$ Congresso Brasileiro de Geologia, Salvador, 21 a 26 set 2014. 
O valor selecionado para este inventário foi o científico e o "framework" é a história geológica da região costeira do estado, no contexto da evolução do Supercontinente Gondwana. Esperou-se, com isso, definir os locais da ilha onde a geodiversidade exibe maior relevância para a pesquisa, em primeiro lugar, e para a educação, em segundo. Desse modo, pretende-se que não só estes locais sejam conservados por instâncias públicas diretamente voltadas para este fim, mas que sejam valorizados e cuidados pela população local que, se apropriando do significado destes elementos de geodiversidade e se relacionando com eles mais diretamente, encontrem identificação no patrimônio geológico.

O valor turístico, embora não prioritário, também foi levado em conta como adicional em pontos onde se faz fortemente aferível, como o do afloramento da Praia de Garapocaia (Pedra do Sino). Sendo Ilhabela uma estância balneária, consideramos difícil, desde as primeiras fases do projeto, olvidar o apelo geoturístico que alguns pontos apresentam.

\subsubsection{Quantificação e classificação}

Para a quantificação dos geossítios, foram utilizados o método de Brilha (2005) e aquele desenvolvido pelo Serviço Geológico do Brasil - CPRM, disposto no sistema GEOSSIT, que conjuga os métodos de Brilha (2005) e Garcia-Cortés \& Carcavilla Urquí (2009). Após a quantificação, os métodos foram comparados e seus resultados, discutidos.

Os geossítios foram então classificados de acordo com sua pontuação. O número de geossítios é pequeno e as ameaças à integridade deles são restritas, devido a características como dimensão e tipos litológicos. Por isso, a quantificação não seria necessária, já que é feita quando a intenção é hierarquizar os geossítios que receberão intervenções para proteção e preservação. Contudo, este trabalho é integrante de um projeto de maior abrangência: "O Patrimônio Geológico Do Litoral Norte Do Estado De São Paulo: Proposta De Geoconservação", sob a responsabilidade da Prof $^{\mathrm{a}} \mathrm{Dr}^{\mathrm{a}}$ Maria da Glória Motta Garcia, justificando, desse modo, a necessidade de quantificar dos geossítios de Ilhabela. 


\subsubsection{Gestão}

A fim de garantir a conservação do patrimônio geológico, torna-se necessário desenvolver estratégias de gestão. As etapas de valorização e divulgação fazem parte da gestão um geossítio.

As diversas iniciativas neste sentido devem priorizar a proteção do patrimônio geológico sem impedir o acesso público (BRILHA, 2005). Porém, muitas vezes é necessário tomar medidas para a restrição de acesso, especialmente quando o risco de vandalismo é alto. Outras medidas de gestão podem ser a modificação dos regimes de propriedade do local, iniciativas no âmbito educacional e mudança nas políticas públicas (GRAY, 2004). Também é importante citar a instalação de infraestrutura para a visitação e segurança.

A interpretação do patrimônio geológico também é uma iniciativa de gestão. Dias \& Brilha (2004) citam entre as formas mais comuns de interpretação os painéis interpretativos, os folhetos e guias turísticos ou geológicos, websites, trilhas, instalação de mirantes e treinamento de monitores. A escolha das estratégias que serão implementadas deve ser feita no intuito de valorizar o patrimônio geológico, além de garantir sua integridade. Por isso, a empreitada deve ser precedida de estudos e levantamentos para delinear o tipo de visitantes, decidir as características que se pretende interpretar nos geossítios e levar em consideração as políticas administrativas do local.

No capítulo 6 encontram-se ideias e estratégias de geointerpretação para os geossítios levantados e que foram surgindo ao longo do tempo da pesquisa. Visando divulgar e proteger a geodiversidade, foram levados em conta a diversidade de idade e o nível de escolaridade do público que visita a ilha, bem como a necessidade de incentivar o geoturismo como alternativa ao turismo centrado nas praias e cuja sazonalidade é desfavorável à economia local. 


\section{A ILHA DE SÃo SEBASTIÃo}

\subsection{LOCALIZAÇÃO}

A cidade de llhabela, classificada com estância balneária e único municípioarquipélago marinho brasileiro, está localizada no litoral norte do estado de São Paulo, especificamente entre as latitudes $23^{\circ} 43^{\prime} 20^{\prime \prime} S$ e $23^{\circ} 58^{\prime} 05^{\prime \prime} \mathrm{S}$ e longitudes $45^{\circ} 00^{\prime} 25^{\prime \prime} \mathrm{O}$ e $45^{\circ} 27^{\prime} 43^{\prime \prime O}$. A ilha faz limite a oeste com o Canal de São Sebastião e a leste com o Oceano Atlântico. Sua área abrange cerca de $340 \mathrm{~km}^{2}$, e, junto com as Ilhas de Búzios, Vitória e Pescadores, 9 outras ilhas, 2 ilhotes e 2 lajes, compõe o Arquipélago de llhabela.

Cerca de $84 \%$ de sua área é protegida pelo PElb - Parque Estadual de Ilhabela. (LUPO \& BORTOLUSSO, 2012), com limites definidos por cotas altimétricas: $200 \mathrm{~m}$ (ao longo do canal), $100 \mathrm{~m}$ (partindo da Ponta da Sela, ao Sul e da Ponta das Canas, ao Norte) e 0 m (próximo da Ponta do Boi, no extremo sul da ilha). A figura 2.1 é um recorte do mapa de Unidades de Conservação Estaduais sob a gestão da Fundação Florestal, onde se podem ver os limites do PEIB e da APA Marinha Litoral Norte, Setor Maembipe, que define a região como área de proteção ambiental marinha de uso sustentável.

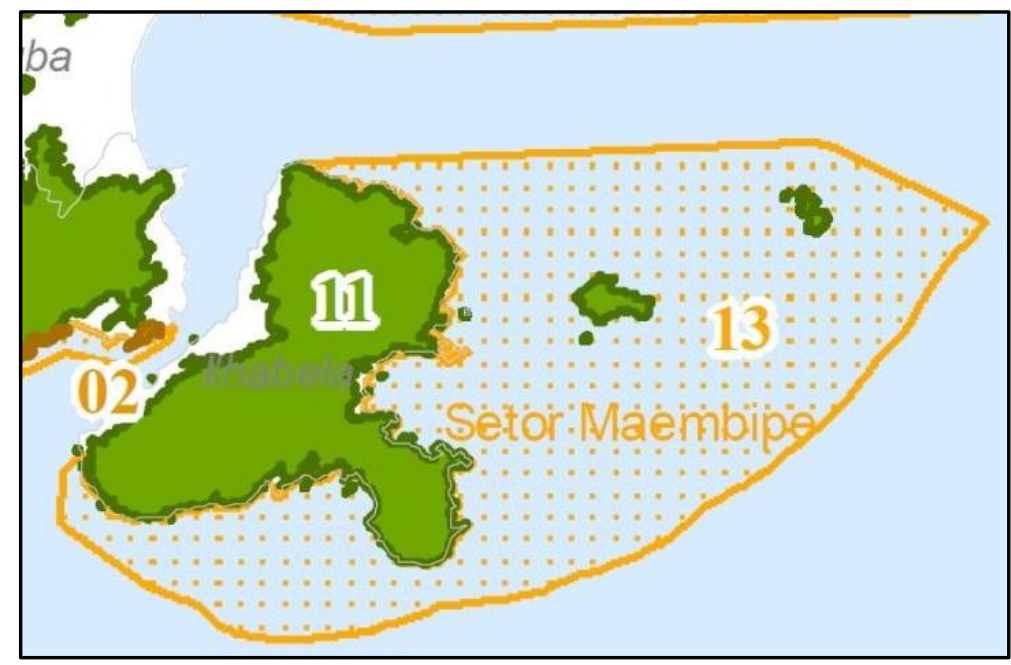

Figura 2.1 - Os limites de abrangência do PEIb (11) e da APA Marinha Litoral Norte, setor Maembipe (13). (FUNDAÇÃO FLORESTAL, 2012) 


\section{2 - CARACTERÍSTICAS DA ILHA}

A região apresenta clima tropical quente e úmido, com volume pluviométrico que oscila entre 1300 e $1500 \mathrm{~mm}$ e temperatura média de 22,5으. O relevo, montanhoso, reflete as características geológicas da ilha, que tem dois de seus maiores picos localizados sobre maciços sieníticos: Pico do Baepi, com $1017 \mathrm{~m}$, sobre o Maciço Serraria, ao Norte, e os Picos do Papagaio (1302m) e de São Sebastião (1379m), sobre o Maciço do mesmo nome, a sudoeste (ILHABELA, 2012; LUPO \& BORTOLUSSO, 2012; SIMÕES,2005).

A área é quase toda recoberta por Mata Atlântica com presença de Floresta Ombrófila Densa, campos e savanas de altitude, restingas e mangues, sendo importante reserva biológica e reduto do cururuá (Phyllomys thomasi), espécie endêmica e ameaçada de extinção (ICMBio, 2012) e do guaiamu (Cardissoma guanhumi Laitrelle), espécie de caranguejo ameaçada de sobre-explotação (GIL, 2009), (Fig.2.2). Algumas das ilhotas do arquipélago servem de refúgio para espécies de aves migratórias.

A população de moradores fixos da cidade flutua em torno de 30 mil, mas aproximadamente 100.000 pessoas compõem uma população flutuante que assoma à ilha nos meses de verão. Segundo levantamentos feitos em março de 2012, a população caiçara está organizada em cerca de 14 comunidades, com 899 moradores, alguns morando em ilhas distantes da cidade, nas ilhas secundárias e no lado leste da ilha, cujo acesso se dá somente por trilhas a pé, por barcos ou veículos $4 \times 4$.
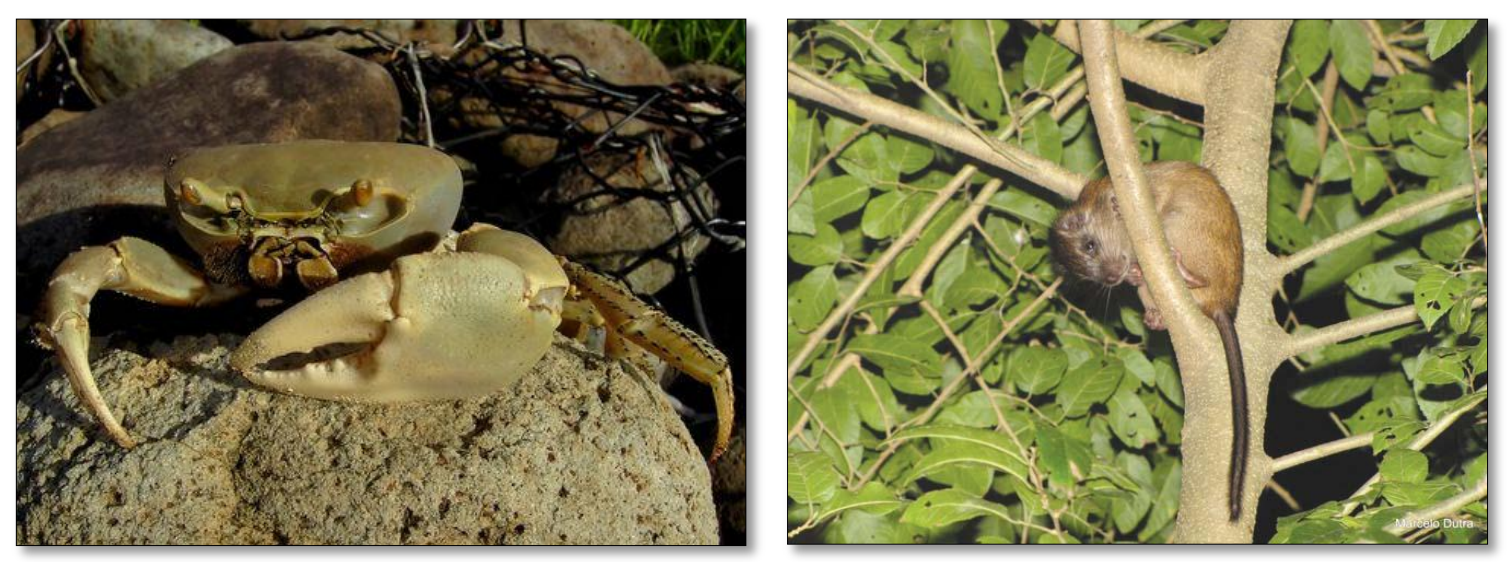

Figura 2.2 - O guaiamú (Cardissoma guanhumi Laitrelle - EOL, 2012), espécie típica do mangue, e o cururuá (Phyllomys thomasi - ICMBIO, 2012), endêmico: espécies que dependem da geodiversidade da llha de São Sebastião.

Finalmente, a ilha apresenta 73 praias, 38 quedas d'água catalogadas ( tendo sido recém-descoberta a Cachoeira do Grande Areado, de cerca de $200 \mathrm{~m}$ e talvez a maior de uma ilha brasileira), 13 trilhas de variados níveis de dificuldade (sendo 6 
mantidas pelo PElb), o entorno pontuado por costões rochosos e uma das maiores grutas de granito do país. Além destas características, que atraem turistas nos meses de alta temporada, a região apresenta inúmeros naufrágios, cavernas submersas, variada fauna marinha e águas transparentes, calmas e cuja temperatura média é $22^{\circ} \mathrm{C}$, propícias para a prática de mergulho (LUPO \& BERTOLUSSO, 2012; PEIb, 2012).

\subsection{CONTEXTO GEOLÓGICO}

A Ilha de São Sebastião está localizada no Terreno Serra do Mar, um dos domínios tectônicos que compõem a Província Mantiqueira. Para efeito de melhor contextualização geológica e de demonstração da importância da geodiversidade do local objeto do presente trabalho, optou-se por descrever, ainda que sucintamente, as características que determinam cada uma destas unidades, partindo da macro para a mesoescala.

\subsubsection{A Província Mantiqueira}

A Província Mantiqueira, tal qual descrita por Almeida (1977), é uma das 10 (15, segundo SCHOBBENHAUS \& BRITO NEVES, 2003) províncias estruturais brasileiras, que assim se caracterizam por apresentar grandes feições de evolução estratigráfica, tectônica, metamórfica e magmática que contrastam daquelas que a circundam (Fig.. 2.3.1a). É um sistema orogênico neoproterozóico desenvolvido durante o evento Brasiliano-Pan Africano que deu origem ao Paleocontinente Gondwana Ocidental (HEILBRON et al., 2004), cuja fase de pico de eventos orogênicos se deu ao redor de 630 Ma (SCHOBBENHAUS \& BRITO NEVES, 2003; HASUI \& OLIVEIRA, 1984). Constitui, juntamente com a extremidade meridional da Província Tocantins, o arcabouço pré-cambriano do sudeste brasileiro desenvolvido em resposta ao "Ciclo Brasiliano" de Almeida (DELGADO et al., 2003).

A província é subdividida em Setentrional, Central e Meridional (HEILBRON et al., 2004), ocupando $450.000 \mathrm{~km}^{2}$ em uma faixa de $3.000 \mathrm{~km}$ de direção NE-SW ao 
longo da região costeira oriental do continente, desde o sul da Bahia até o Uruguai (ALMEIDA, 1977; HASUI \& OLIVEIRA,1984; HEILBRON et al., 2004) e encontra limites nas províncias Tocantins, São Francisco e Paraná, e nas bacias costeiras do Espírito Santo, Campos, Santos e Pelotas (Fig. 2.3.1b).

Constituem a província os orógenos Araçuaí, Ribeira, Dom Feliciano e São Gabriel e a zona de interferência entre os orógenos Brasília e Ribeira. Um conjunto de unidades que se estendem da zona de interferência para sul até o craton Luis Alves é agrupado nos terrenos Apiaí-Guaxupé e Embu, pois suas relações geotectônicas com um e outro orógenos que participam da zona de interferência ainda não foram totalmente esclarecidos.

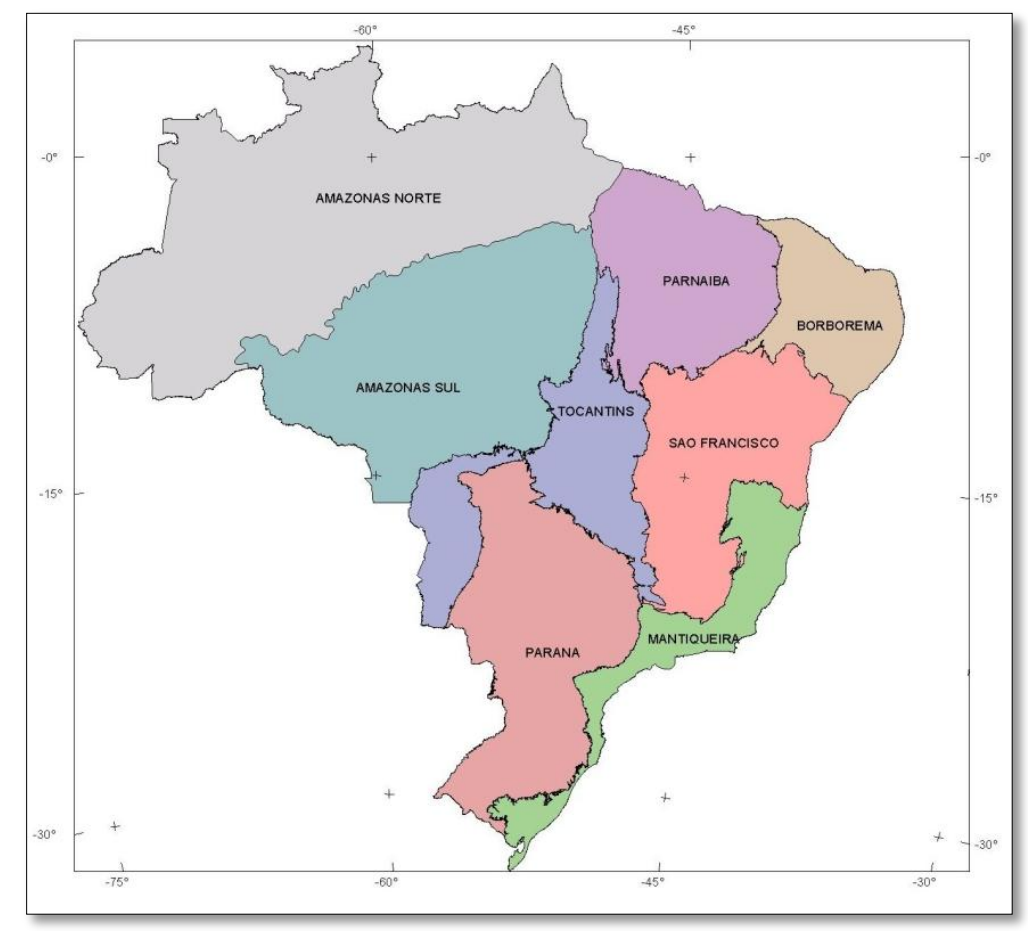

Figura 2.3.1a - Províncias estruturais de Almeida et al. ${ }^{1}$ (1977, apud Dantas, 1980). Fonte: http://www.dnpm.gov.br/dstpe/trabalhos/Sint_PE/SintesePE_02.htm

A evolução orogênica da Província foi diacrônica: houve o desaparecimento dos oceanos Goianides e Adamastor, seguido por processos de subducção que geraram suítes de arcos magmáticos. A esta subducção, seguiram-se colisões arco-

\footnotetext{
${ }^{1}$ Almeida, F.F.M. O Cráton do São Francisco. Revista Brasileira de Geociências, v.7, p. 349-
} 364, 1977. 
continente e continente-continente e, finalmente, houve o colapso tectônico dos orógenos contidos na província.

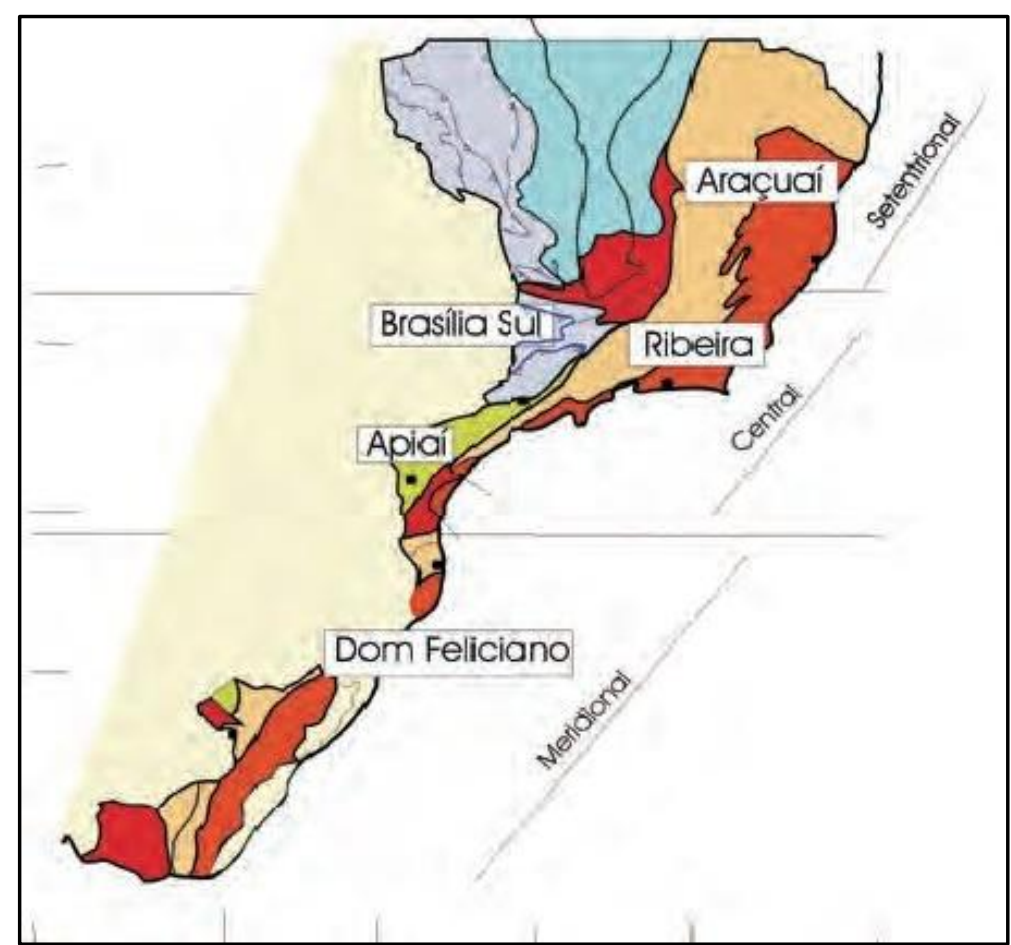

Figura 2.3.1b - Os orógenos que compõem a Província Mantiqueira e sua subdivisão em segmentos:

Setentrional (Araçuaí), Central (Brasília Sul, Ribeira e Apiaí) e Meridional (Dom Feliciano e São Gabriel).(HEILBRON et al., 2004).

Em seu último estágio de evolução, a região alojou pequenas e numerosas bacias, que receberam sedimentos molássicos e lavas de composição ácida a intermediária. Esta região também é cortada por falhas transcorrentes, longitudinais e que parecem ter sofrido reativação ao final do Pré Cambriano e início do Paleozoico (ALMEIDA, 1977).

A delimitação da província foi auxiliada pelo surgimento dos Arcos de Ponta Grossa e Riograndense, bordejando a Bacia do Paraná, no Paleozóico. Posteriormente, enxames de diques de diabásio e numerosos stocks alcalinos intrudiram a Província, na ocasião da reativação meso-cenozoica da Plataforma Sulamericana, que permitiu também o alojamento de bacias tafrogênicas, as quais receberam sedimentos lacustres e fluviais durante o Cenozoico (ALMEIDA, 1977; HASUI, 2010; HEILBRON et al., 2004). 


\subsubsection{O Orógeno Ribeira}

Comumente chamado de Faixa ou Cinturão Ribeira e assim denominado devido a uma unidade geotectônica que aflora no vale do Ribeira, este orógeno foi resultado do fechamento do Oceano Adamastor, na convergência dos crátons São Francisco, Congo e um terceiro, inferido, cujos remanescentes se escondem abaixo dos sedimentos fanerozoicos da Bacia do Paraná, durante o Estágio Colisional II do Ciclo Brasiliano, entre 590 e 560 Ma (HEILBRON et al., 2008, TROUW et al., 2000),

A Faixa Ribeira apresenta trend estrutural NE-SW e o resultado da Colisão II (supra citada), oblíqua, resultou em empilhamento de terrenos de leste para oestenoroeste, com a deformação principal claramente separada entre duas zonas, uma com encurtamento frontal e outra com componente transpressivo destral. Zonas de cisalhamento oblíquas transpressivas e falhas de empurrão separam os cinco terrenos que constituem a faixa: Ocidental, Paraíba do Sul, Embu, Oriental (Costeiro ou Serra do Mar), que apresentam idade de colagem de 580 Ma, e Cabo Frio, cuja amalgamação se deu há ca 520 Ma (HEILBRON et al., 2004).

Devido à presença de sistemas de nappes, zonas de cisalhamento dúcteis de alto ângulo (e sua associação a granitoides foliados em escala regional), ocorrência de rochas miloníticas, dobras isoclinais e em bainha e o comportamento oblíquo das estruturas lineares, o Cinturão tem sido interpretado como um cinturão transpressivo. Maffra (2000) interpretou a existência de estruturas em flor associadas às zonas de cisalhamento dúcteis em São Sebastião como prova dessa inferência, pois há forte incidência de plutonismo na região, na presença de corpos graníticos de forma alongada, ocupando o eixo XY do elipsoide de deformação. Por estas evidências, acredita-se que o modelo mais apropriado para interpretação do tectonismo da região seja o de subducção de crosta oceânica, cujo sentido de mergulho é ainda controverso.

É digna de nota a segmentação da Faixa Ribeira feita por Dias Neto et al. (2006), para efeito de estudo, devido às suas grandes dimensões: i) setor norte, localizado no estado do Espírito Santo e a oeste de Minas Gerais, com tectônica oblíqua em relação à direção regional e cavalgamentos para oeste; setor central, no estado do Rio de Janeiro e no leste do estado de São Paulo, com metamorfismo de grau médio a alto e predominância de deformação por cisalhamentos verticalizados; 
e iii) setor sul, no sul do estado de São Paulo e norte do estado do Paraná, com rochas metassedimentares de grau metamórfico baixo.

Maffra (2000), no entanto, cita uma outra divisão do Cinturão Ribeira que foi motivada pela predominância de certas estruturas: i) parte interna, com movimentos horizontais e zonas de cisalhamento transcorrentes de alto ângulo; ii) porção intermediária, com cavalgamentos e dobras; e iii) parte externa, com a deformação afetando unidades supra-crustais (EBERT; HASUI; SENA COSTA, 1991, apud ${ }^{2}$ MAFFRA, 2000)

O evento de Reativação da Plataforma Brasileira, com a consequente abertura do Oceano Atlântico no Neocretáceo (ca.130 Ma) causou intensas mudanças na região devido ao regime distensional, desde fase pré-rift, com magmatismo toleítico intenso na Bacia do Paraná (Fm. Serra Geral) e enxames de diques controlados pelo lineamento estrutural do Arco de Ponta Grossa (COUTINHO, 2008; GARDA \& SCHORSCHER,1996; RICCOMINI, VELÁZQUEZ, GOMES, 2005; ZALÁN, 2004).

No início do Paleógeno (Neo-Paleoceno), com novos movimentos distencionais, há a formação do Rifte Continental do Sudeste, concomitante à formação de pequenas bacias e novos episódios de magmatismo alcalino, e o soerguimento crustal que compensou isostaticamente o afundamento da Bacia de Santos e que perdurou até o Neo-mioceno (ALMEIDA \& CARNEIRO, 1998; RICCOMINI, 1989; ZALÁN, 2004;). O evento distencional também atuou sobre o que foi um grande planalto soerguido no Sudeste Brasileiro, elevando os blocos adjacentes, delimitando montanhas separadas entre si por grábens continentais e formando, com isso, as Serras da Mantiqueira e do Mar e o Maciço Carioca.

Ainda sobre o evento de abertura do Atlântico, Garda e Schorscher (1996) definem duas fases, sendo a primeira representada por diques e sills de caráter intermediário a básico e a segunda, por stocks e chaminés de rochas alcalinas. $\mathrm{O}$ magmatismo alcalino nas fases rift e oceano também é defendido por Riccomini et al. (2005) e Almeida (1983). Almeida pontua que, ao contrário do magmatismo toleítico, que se deu em grandes volumes em derrames, enxames de diques e sills, o alcalino aconteceu em pequenas ocorrências pontuais. Essas expressões do

${ }^{2}$ EBERT, H.D.; HASUI, Y.; SENA COSTA, J.B. 0 caráter transpressivo do Cinturão Transcorrente Rio Paraíba do Sul. In SBG, Simpósio National De Estudos Tectônicos, v.3, Anais, p.139-141, 1991. 
magmatismo alcalino, presente nas fases rift, oceano, e logo depois, no Cenozoico (quando acontece o desenvolvimento das bacias tafrogênicas e as derradeiras manifestações deste vulcanismo alcalino), ocorreram em todo o redor da Bacia do Paraná e foram sistematicamente divididas em 13 províncias alcalinas pelo autor. A Ilha de São Sebastião, com três grandes maciços alcalinos, faz parte da Província Alcalina Serra do Mar (ALMEIDA, 1983; ENRICH, 2005).

Em sua parte central, no Estado do Rio de Janeiro, a faixa Ribeira é composta pelos Terrenos Ocidental, Oriental (ou Microplaca Serra do Mar) e Cabo Frio, e a klippe Paraíba do Sul (HEILBRON et al., 2004). No Terreno Oriental se localizam os domínios estruturais Cambuci, Italva e Costeiro

Em São Paulo, a região da Faixa Ribeira que envolve o Sudeste conta com os terrenos Serra do Mar (Domínio Costeiro), Embu e São Roque, separados por expressivas zonas de cisalhamento e apresentando características (idade dos protólitos crustais e assembleias litológicas) distintas entre si (TASSINARI \& CAMPOS NETO, $1988^{3}$ apud DIAS NETO et al, 2006), (Fig.2.3.2).

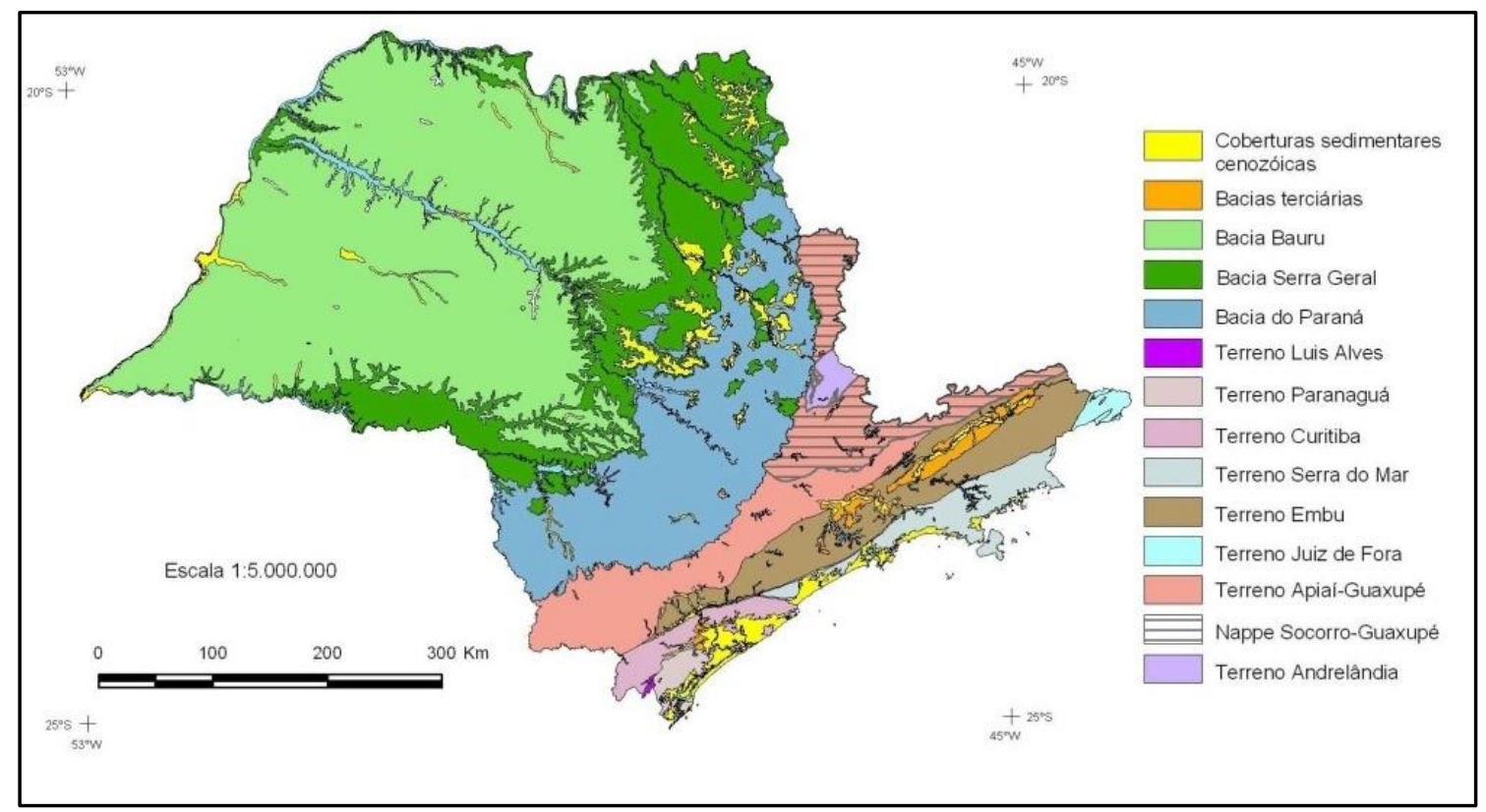

Figura 2.3.2 - As entidades tectono-estratigraficas do estado de São Paulo (PERROTTA et al., 2005)

${ }^{3}$ TASSINARI, C.C.G.; CAMPOS NETO, M. Precambrian continental crust evolution of Southeastern São Paulo State, Brazil: Based on isotopic evidences. Geochimica Brasiliensis, v. 2, n. 2, p. $175-183,1988$. 


\subsubsection{Terreno Serra do Mar (Domínio Costeiro)}

Limitado ao norte pela Falha de Cubatão, e ao sul pela linha de costa, o Domínio Costeiro é densamente controlado por falhas tardibrasilianas que se distribuem em feixes de descontinuidades subparalelas e oblíquas, por vezes anomostosantes. O mais imponente destes feixes é o que constitui a Faixa de Cisalhamento São Paulo. Este feixe de falhas, com largura de 70 a 100 km surge na região de Juiz de Fora (MG) e Santo Antônio de Pádua (RJ) e segue na direção $S E$, para desaparecer por sob os sedimentos da Bacia do Paraná na região próxima a Itu. Dele fazem parte importantes falhas que regulam a compartimentação litoestratigráfica: falhas de Cubatão, Taxaquara, Monteiro Lobato, Itu e Jundiuvira.

Composto por rochas metamórficas de alto grau e granitos bastante deformados, o Domínio Costeiro apresenta três conjuntos litológicos distintos: rochas gnássico-migmatíticas, rochas paraderivadas e rochas granulíticas. Dias Neto (2001) faz uma revisão das litologias predominantes no Domínio Costeiro, que estão sumarizadas na tabela 2.3.3.

\begin{tabular}{|c|c|}
\hline Litologia & Características \\
\hline $\begin{array}{l}\text { Conjunto } \\
\text { gnáissico- } \\
\text { migmatítico }\end{array}$ & $\begin{array}{l}\text { Paleossoma de hornblenda-biotita gnaisse } \\
\text { Neossoma de composição granodiorítica }\end{array}$ \\
\hline Metassedimentos & $\begin{array}{l}\text { Rochas síltico-argilosas } \\
\text { Quartzitos arcosianos e rochas calciossilicáticas subordinadas } \\
\text { Ocorrem boudins máficos-ultramáficos ( } \mathrm{cm} \text { a m) no interior dos } \\
\text { paragnaisses }\end{array}$ \\
\hline Rochas granulíticas & $\begin{array}{l}\text { Charnoquitos e noritos } \\
\text { Gnaisses oftalmíticos associados }\end{array}$ \\
\hline Outros & $\begin{array}{l}\text { Batólitos graníticos (Natividade da Serra e Caraguatatuba) } \\
\text { Charnoquito de Ubatuba } \\
\text { Outros corpos granítico-porfirítcos, tardi a pós-tectônicos, álcali- } \\
\text { cálcicos }\end{array}$ \\
\hline
\end{tabular}

Tabela 2.3.3 - Principais litologias do Domínio Costeiro (com base em Dias Neto, 2001) 
Garda (1995), no entanto, reconhece no Complexo Costeiro, diversas sequências de gnaisses e migmatitos com severa heterogeneidade e irregularidade de tipos litológicos, e os divide em cinco unidades: quartzítica, ortognáissica, gnaisses peraluminosos, granito gnáissica migmatítica e gnaisses bandados.

O padrão de deformação da região é causado por grandes zonas de cisalhamento de direção NE-SW e, por isso, a foliação e a xistosidade das rochas metamórficas da região é forte e penetrativa. Além disso, estruturas em leque relacionadas às zonas de cisalhamento dúctil sugerem um regime transpressivo destral na evolução do Cinturão (SADOWSKI, 1991).

Tassinari (1988) sintetizou o padrão geocronológico regional para o Domínio Costeiro no estado de São Paulo: idades entre 650 - $600 \mathrm{Ma}$ (Rb-Sr), com corpos graníticos tardiorogênicos, com idade de instalação de $550 \mathrm{Ma}$. Os valores obtidos tanto em rochas metamórficas quanto nos corpos graníticos sugere processos de fusão parcial e remobilização de materiais mais antigos (DIAS NETO, 2001). Idades $\mathrm{Sm}-\mathrm{Nd}$ ao redor de $2.000 \mathrm{Ma}$ sugerem que as rochas do Complexo Costeiro se originaram no Paleoproterozoico e as idades K-Ar, entre 500 e $450 \mathrm{Ma}$, apontam para um resfriamento regional perdurando até o Ordoviciano Médio (TASSINARI, 1988).

\subsection{A GEODIVERSIDADE DE ILHABELA}

A llha de São Sebastião está assentada sobre litologias representativas e de relevante valor científico, pois ilustram com propriedade os eventos tectônicos que a porção sudeste da Província Mantiqueira testemunhou nos últimos 650 milhões de anos: o Ciclo Brasiliano, com os terrenos que se amalgamaram na formação do Gondwana; a quebra de Pangea e abertura do Oceano Atlântico; os sistemas de falhas e zonas de cisalhamento, reativadas durante o Cretáceo; o magmatismo alcalino que sugerem a ideia da migração da Pluma mantélica de Trindade. Sendo parte integrante da Província da Serra do Mar, as rochas alcalinas também testemunham não só o reajuste isostático por soerguimento para contrapor a então ocorrente subsidência da Bacia de Santos, mas também o subsequente surgimento 
de blocos adernados da Serra do Mar (ALMEIDA, 1983; GARDA \& SCHORSCHER, 1996; RICCOMINI et al. 2005).

\subsubsection{A geologia da ilha}

A ilha faz parte do Domínio Costeiro, supracitado, e foi separada do continente durante o Cretáceo Inferior, quando da abertura do Oceano Atlântico Sul. Por isso, apresenta o embasamento cristalino neoproterozoico granito-gnássico e migmatítico (LIMA, 2001). As rochas pré-cambrianas estão representadas por granito-gnaisses grossos, biotita gnaisses, gnaisses bandados, rochas cálciosilicáticas, granitos porfiríticos foliados, gnaisses migmatíticos milonitizados e álcali sienitos (BARRETO, 2012).

Segundo Sato (2006), "as rochas metamórficas da ilha, apresentam a foliação milonítica marcada pela isorientação de micas e anfibólios. Os migmatitos são caracterizados por texturas estromáticas, com mesossoma gnáissico, leucossoma granítico e melanossoma formado por bandas centimétricas de minerais máficos.".

No Cretáceo superior, ca $80 \mathrm{Ma}$, com reativação dos falhamentos de orientação principal NE, o magmatismo alcalino teve sua expressão através de 3 grandes stocks de sienitos que sustentam a geomorfologia acidentada e os picos de elevada altitude da ilha. Os maciços são denominados Serraria (ao norte), Mirante (a sudeste) e São Sebastião (a sudoeste). A noroeste da ilha há também um pequeno stock, denominado "das Canas", de rocha básica alcalina. Freitas (1947) destacou que estas intrusões ocupam quase a totalidade da ilha $\left(300 \mathrm{~km}^{2}\right.$ de $\left.336 \mathrm{~km}^{2}\right)$ e por isso, a ilha é considerada uma das representações mais expressivas deste tipo de magmatismo.

Ainda no Mesozoico, enxames de diques cortaram a ilha, a maioria seguindo a direção preferencial das falhas, NE-SW. As relações entre os maciços, o embasamento e as duas gerações reconhecidas de diques são dadas por datações e por elementos estruturais e relações de prevalência, subordinação e interrupção. Intrusões gabroicas estratiformes completam o quadro do plutonismo mesozoico da ilha. Podem-se reconhecer três fases distintas no magmatismo mesozoico representado pelos diques, intrusões e maciços da ilha (BELLIENI et al. 1990; 
FREITAS, 1947; GARDA, 1995; GARDA \& SCHORSCHER, 1996; HENNIES \& HASUI, 1977; LIMA, 2001).

Magmatismo vulcânico inicial (120 a 140 Ma): diques cortam o embasamento, mas não os batólitos e stocks alcalinos. Predomínio de rochas básicas a andesíticas máficas, lamprófiros ultramáficos. Leucoandesitos e dacitos porfiríticos e ultrabasitos ricos em carbonato magmáticos são raros.

Estágio plutônico principal: Os três stocks já citados (ca 80 - $85 \mathrm{Ma}$ AMARAL et al., 1967; HENNIES \& HASUI, 1968) representam este estágio. Há o franco predomínio de rochas alcalinas intermediárias a ácidas (leucocráticas a hololeucocráticas de granulometria grossa, estrutura maciça a acamada e cor cinza claro a branco). Raros gabros, dioritos, piroxenitos e equivalentes alcalinos, encontrados na Ponta da Pacuíba, na Praia do Garapocaia (95 Ma para os essexitos da Pedra do Sino - AMARAL et al., 1967) e no Stock das Canas (86 Ma para um gabro rolado - HENNIES \& HASUI, 1968).

Magmatismo hipoabissal a subvulcânico final (81 a $55 \mathrm{Ma}$ ): diques, veios e corpos menores (não representados em mapas geológicos, devido à irregularidade e extensão minoritária) cortam os batólitos e stocks da fase anterior. As rochas abrangem desde ultramáficas a leucocráticas, em geral alcalinas, de muito grossas e pegmatóides (hipoabissais) a faneríticas médias e finas (subvulcânicas rasas) e porfiríticas. Incluem piroxenitos,microgabros, fonolitos, microsienitos diversos, teschenitos, diabásios raros e subordinados e traquitos.

Sedimentos quaternários marinhos (arenitos e siltitos) e continentais (depósitos de tálus e sedimentos coluvionares) ocorrem nas planícies litorâneas, devido à morfologia do terreno, que exibe declividade alta (MAFFRA, 2000). Estes sedimentos tem sua proveniência mais precisamente no intemperismo das rochas do pré-cambriano, pela maior erodibilidade. Nos pontos onde afloram as magmáticas mesozoicas, há a formação de costões, muitas vezes com sienitos apresentando caneluras bem pronunciadas (HENNIES \& HASUI, 1977). 


\subsubsection{Mapas geológicos da ilha}

Apesar de sua rica geodiversidade, a área somente começou a ser melhor estudada mais recentemente e ainda carece de mapeamentos completos, especialmente no que se refere aos contatos entre o embasamento e os sienitos, pois é gradacional, com zonas de assimilação e misturas de decímetros (BARRETO, 2013). O mapa mais recente é o publicado pela CPRM (PERROTTA et al., 2005)., que ainda não contempla toda a diversidade de tipos litológicos da ilha (Fig. 2.4.2a).

Freitas (1947) foi o pioneiro na empreitada, publicando um mapa bastante completo, (mas que hoje é visto com ressalvas, por apresentar pequenos corpos sieníticos inexistentes, descrever rochas quartzo-dioríticas pós-alcalinas não descritas por outros autores e não representar o stock das Canas). Hennies e Hasui publicaram uma versão preliminar somente 21 anos depois. Porém, em 1977, publicam um artigo sobre as rochas alcalinas da ilha, abordando a geologia e apresentando um mapa mais detalhado do local (Fig.2.4.2b).

O Mapa Geológico do Estado de São Paulo feito pelo IPT data de 1981, traz o texto explicativo sobre as rochas da região separadas por unidade de tempo geológico, e, apesar de simples, indica alguns diques (Fig.2.4.2c). Em 1990, Bellieni et al. estudaram a geoquímica e a petrologia do magmatismo da ilha e publicaram um mapa na escala de 1:200.000 (fig.2.4.2d). Finalmente, em 2005 a CPRM publicou a versão atualizada do mapa geológico do Estado de São Paulo, com notas explicativas, supra citado.

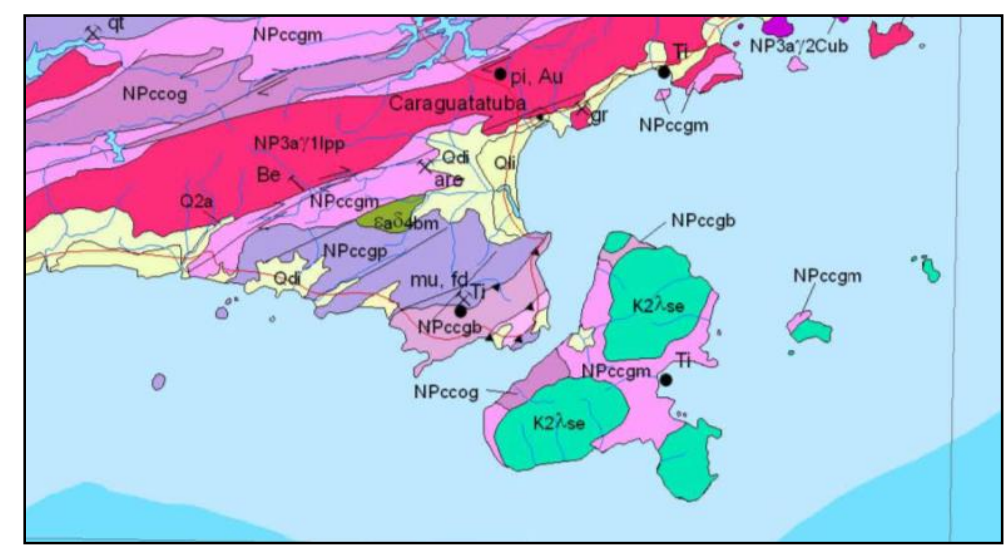

Figura 2.4.2a - O contexto da llha de São Sebastião no recorte do mapa da CPRM (PERROTTA et al., 2005), que não contempla a geodiversidade da ilha. 


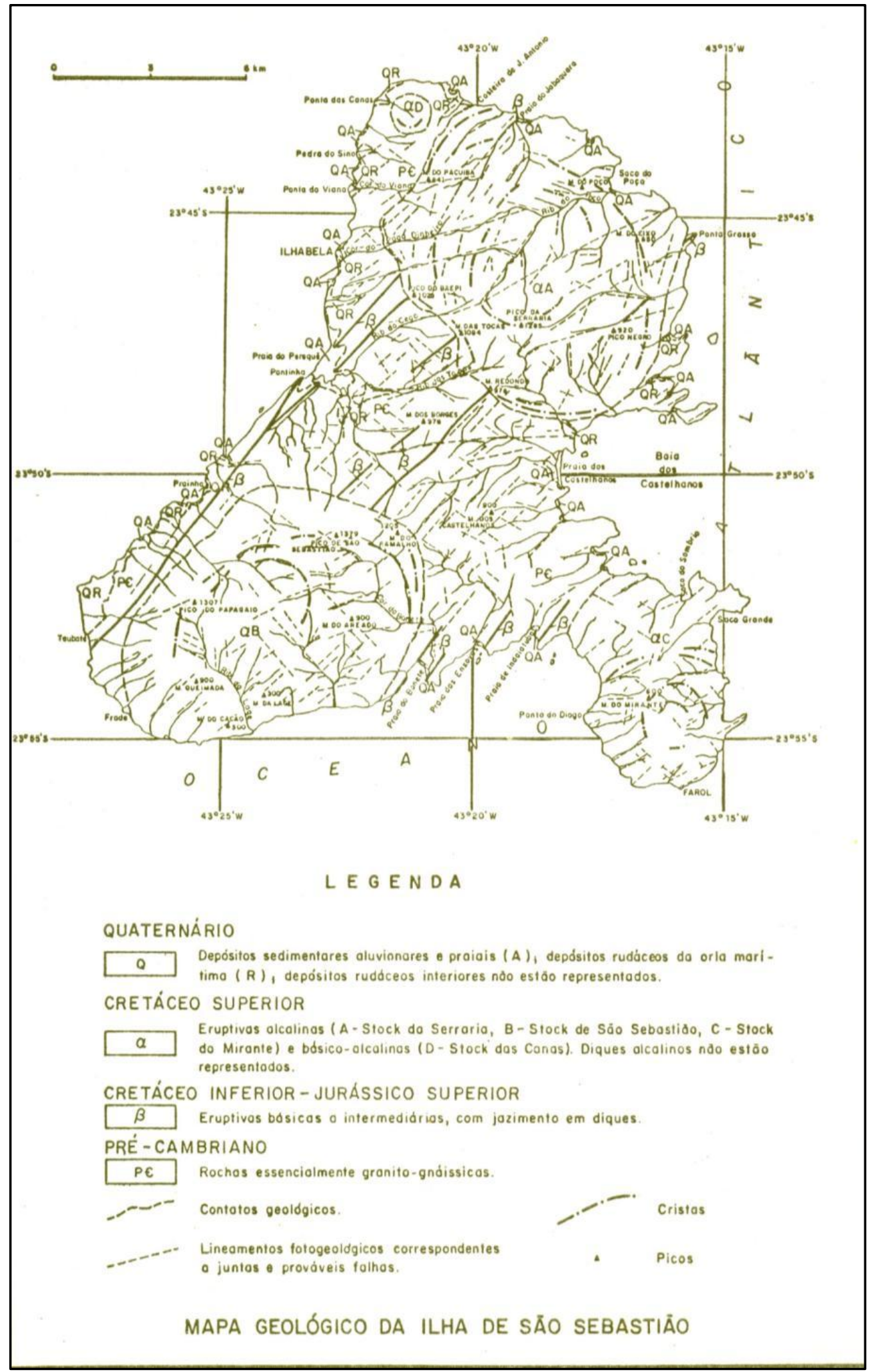

Figura 2.4.2b - Mapa geológico da ilha de São Sebastião, por Hennies e Hasui (1977) 


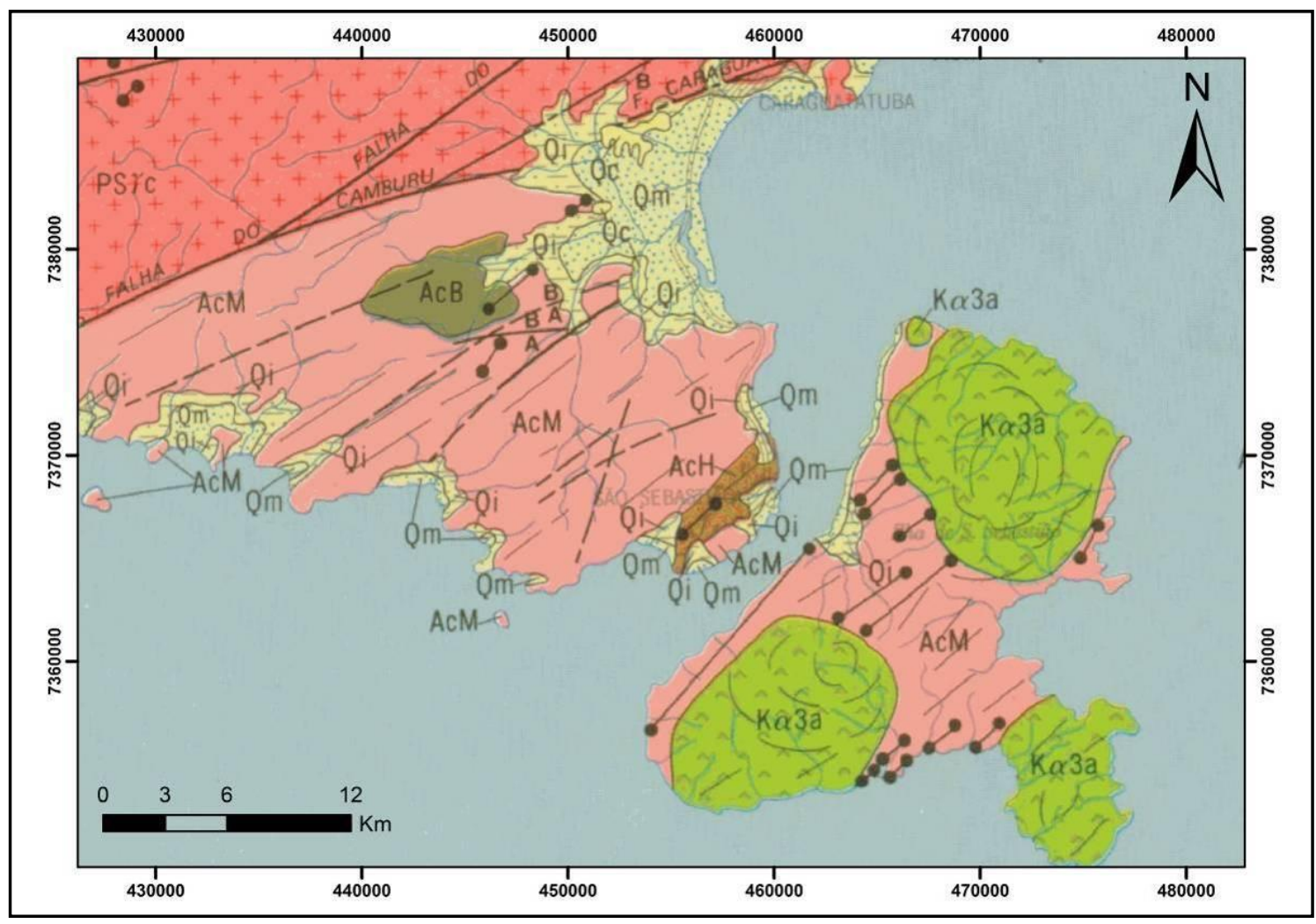

\begin{tabular}{|c|c|c|c|c|}
\hline \multicolumn{5}{|c|}{ LEGENDA: } \\
\hline Qm & \multicolumn{3}{|c|}{$\begin{array}{l}\text { Sedimentos Marinhos Mistos: Sedimentos atuais e subatuais, induindo termos arenosos } \\
\text { praiais, depósitos marinhos localmente retrabalhados por açáo fluvial elou eólica, termos } \\
\text { areno-sitico-argilosos de deposiçăo flúvio-marinho-lacustre edepósitos de mangue. }\end{array}$} & $\begin{array}{l}\text { Contato geológico } \\
\text { A. F F l In a me } n \text { tos de }\end{array}$ \\
\hline Q1- & \multirow{2}{*}{\multicolumn{3}{|c|}{$\begin{array}{l}\text { Sedimentos Continentais Indiferenciados: Depósitos continentais induindo sedimentos } \\
\text { elúvio-coluvionares de natureza areno-argilosa e depósitos de caráter variado associados a } \\
\text { encostas. } \\
\text { Sedimentos do Grupo Mar Pequeno / Formação Cananéia: Areias marinhas finas } \\
\text { inconsolidadas frequentemente limonitizados, com presença de esparsos leitosargilosos. }\end{array}$}} & $\begin{array}{l}\text { gravidade (encobertos } \\
\text { quando pontilhados) } \\
\text { movimento relativo dos } \\
\text { Blocos: } A=\text { atto; } B=\text { baixo. }\end{array}$ \\
\hline Pc & & & & $\begin{array}{l}\text { fraturas. } \\
\text { framentosinferidose }\end{array}$ \\
\hline \multicolumn{4}{|r|}{ MESOZÓICO } & $\begin{array}{l}\text { - Diques básicos } \\
\text { mesozóicos. }\end{array}$ \\
\hline$K a 3 a$ & \multicolumn{3}{|c|}{ 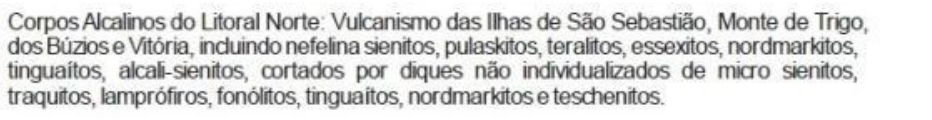 } & \\
\hline \multicolumn{4}{|r|}{ PRECAMBRIANO } & \\
\hline$P S T C$ & \multicolumn{3}{|c|}{$\begin{array}{l}\text { Suite Granitica Sintectônica - Fácies Cantareira - Correspondente ao Granito Pico do } \\
\text { Papagaio: Corpos paraautóctones e alóctones, foliados, granulaçâo fina a média, textura } \\
\text { porfirítica frequente; contatos parcialmente concordantes e composiçäo granodioritica a } \\
\text { granitica. }\end{array}$} & \\
\hline $\mathrm{AcM}$ & $\mathrm{ACH}$ & $A C B$ & \multirow{2}{*}{$\begin{array}{l}\text { Complexo Costeiro - AcM: Piroxênio granulitos, granulitos quartzo } \\
\text { fesdspáticos, kinzigitos, charnoquitos e rochas granito-gnaissicas a } \\
\text { hiperstênio, incluindo anfibolitos e serpentinitos localmente } \\
\text { migmatizados. AcH:Charnoquitos, kinzigitos e rochasgranito- } \\
\text { gnáissicas a hiperstênio com migmatizaçấo e feldspatização } \\
\text { sobrepostas. AcB: Metadioritos, quartzo gabrosequartzo dioritos. }\end{array}$} & \\
\hline & & & & \\
\hline
\end{tabular}

Figura 2.4.2c - Recorte do Mapa Geológico do Estado de São Paulo mostrando a área da llha de São Sebastião (IPT, 1981). 


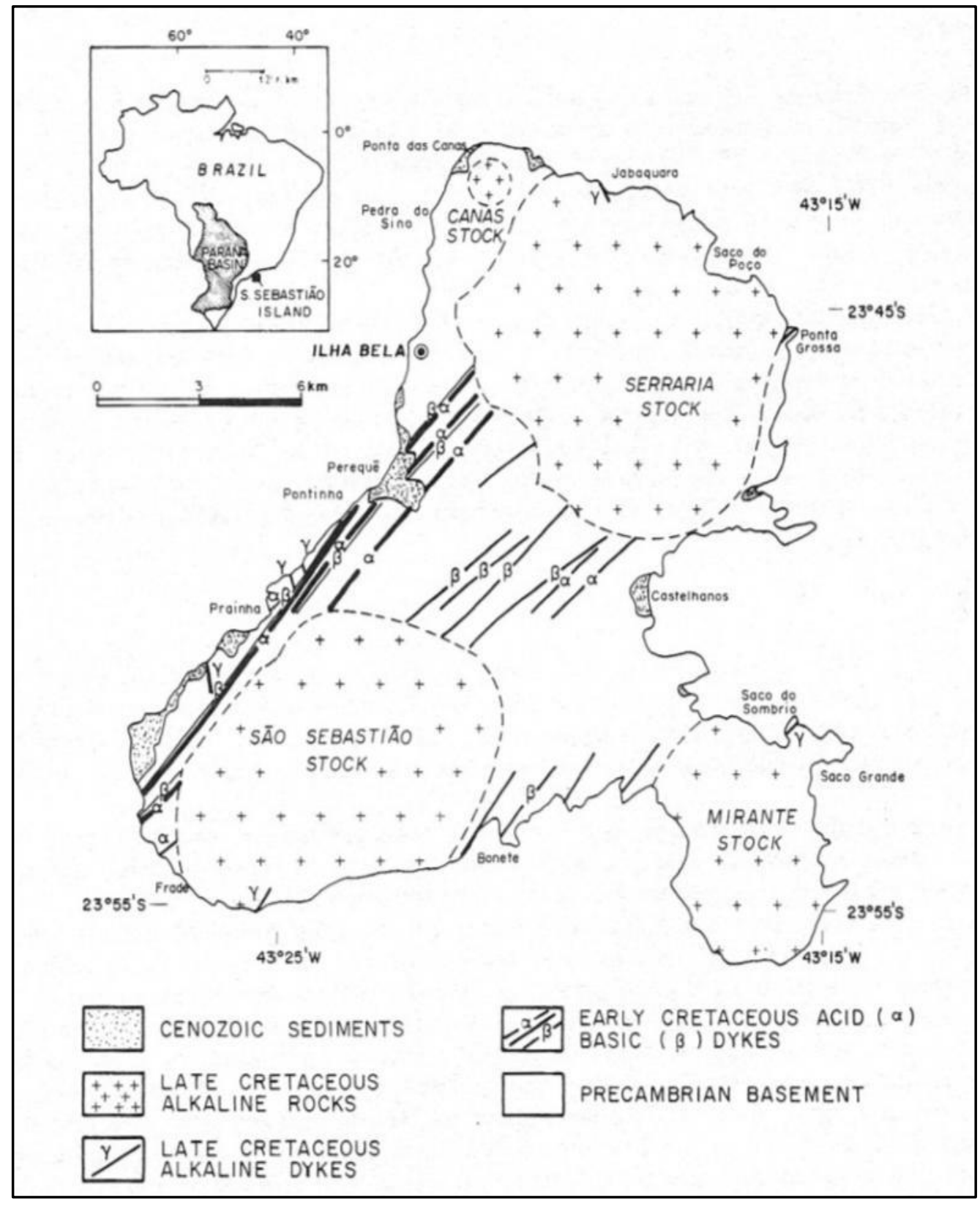

Figura 2.4.2d - Mapa geológico da llha de São Sebastião de Bellieni et al (1990). 


\section{GEODIVERSIDADE E GEOCONSERVAÇÃO: CONCEITOS}

\subsection{EM BUSCA DE EXPLICAÇÕES}

É inerente ao ser humano a urgência de formular explicações para o que o espanta. A história da humanidade é marcada pelas lutas que o humano travou com as intempéries e as difíceis condições de sobrevivência. Estando à mercê das manifestações do planeta, sofrendo fome, frio e desamparo, desde muito cedo aprendemos a venerar e respeitar o que convencionamos chamar de "deuses", personificados no vento, na chuva, nos astros, no chão que por vezes sacudia, ou nos mares que, raivosos em certas ocasiões, engoliam nossas frágeis embarcações com suas ondas gigantes (BOCZKO,1984; FRIAÇA et al., 2000).

Essas deidades receberam a culpa por nossos desesperos e alegrias cotidianas. Histórias fabulosas explicaram as estações do ano, a duração do dia e da noite, as pestes e as plantações que não vingavam. Com a criação do mundo e das formas de vida, não foi diferente. Em vista de uma miríade de expressões de vida e geomorfologias distintas, o ser humano não pôde encontrar outro modo de explicá-las, senão legando a um ou vários deuses a tarefa de desenhar o mundo e os seres vivos com imensa criatividade (LEEMING, 2005).

Entretanto, não foi sempre assim. Houve um tempo em que somente utilizávamos os recursos que a natureza nos oferecia. Mithen (2002) observou que "o $H$. habilis não apresentava processos de pensamento particularmente avançados para a manufatura de artefatos e o mundo natural". De maneira análoga, Neandertais tinham "consciência ondulante" ao fabricar suas ferramentas de pedra, algo similar ao que apresentamos quando dirigimos e conversamos ao mesmo tempo: ao final do trajeto não lembramos peculiaridades dele. Não há indícios de que existisse introspecção. A pedra, em si, não era um ente fantástico e a atividade de se confeccionar uma ferramenta era apenas uma percepção inconsciente e ação inteligente, com perda instantânea de memória.

O que os arqueólogos convencionam denominar "explosão cultural", se deu na transição do Paleolítico Médio ao Superior (45 a 30 mil anos), com o surgimento de artefatos de ossos e pinturas rupestres, pelo Homo sapiens sapiens, ou "homem 
moderno". Com isso, podemos perceber que a necessidade de explorar os recursos naturais se deu muito antes de inventarmos explicações para o surgimento deles.

Há cerca de 10 mil anos, os humanos iniciaram as atividades de agricultura, e se libertaram da sina de coletores e caçadores, resultado, segundo Mithen (2002), de uma evolução de um cérebro do tipo "canivete suíço", para outro com notável fluidez cognitiva. Ao contrário do que se pensa, essa mudança esteve longe de trazer benefícios nutricionais, mas pode ter sido uma alternativa para alimentar uma população crescente e menos móvel. É preciso lembrar que a troca de um modo de vida nômade para outro, mais sedentário, motivou uma produção agrícola cada vez maior. Assim, foi necessário domesticar animais e prever as condições do tempo, que mudavam constantemente (com um aquecimento considerável em poucas décadas, ao final da última glaciação).

O homem moderno passou a se utilizar da natureza conscientemente, a qual, em vários casos, fornecia elementos cujo acúmulo proporcionava status social. Rapidamente nos apossamos dos recursos naturais e passamos a utilizá-los de forma intensa. Porém, esta mudança de estilo de vida não acarretou problemas ambientais sérios, apesar de a população aumentar, já que havia um limite tecnológico para a extração desses recursos. Ainda assim, o homem, refém da natureza, precisou encontrar maneiras de explicar aquilo que o amedrontava e controlava sua existência.

\subsection{USUFRUTO DO HOMEM: UM EQUÍVOCO DE BASES HISTÓRICAS ANTIGAS}

Com o passar dos séculos e o estabelecimento da cultura, da escrita e da ciência, propagou-se uma noção de estética matemática, que teve um dos pilares fundamentados na Grécia antiga, em Aristóteles, para quem a ideia de perfeição da natureza se aliava à de funcionalidade (ABRANTES, 1998). Gray (2004) pondera que esta visão influenciou fortemente os pensadores da Idade Média e da Renascença, por quem a diversidade no planeta era vista com desespero, pois essa miríade de formas e conteúdos não se assemelhava ao círculo, que seria o símbolo da perfeição divina, o intuito do ser especial que havia criado tudo. 
Claramente, também, por ter sido criada por um deus, à sua imagem e perfeição, a espécie humana deveria estar acima de todas as coisas e usufruir da obra da criação. Esta mentalidade equivocada prevaleceu por muitos séculos e ainda hoje é arraigada na população em geral. Em 1780, Toulmin disse que "o grosso da espécie humana arrogantemente se eleva acima das inumeráveis existências que o cercam", enquanto Francis Bacon, cientista do séc.XVII, afirmou que "todas as criaturas foram feitas para o homem, sujeitas a seu governo e destinadas a seu uso", (Toulmin, 1780 apud THOMAS, 1989).

Esta criação, adiciona Thomas (1989, p.24), seria tão perfeita, que seu criador teria pensado em tudo:

\begin{abstract}
Foi tendo em mente as necessidades humanas que Deus criteriosamente projetou e distribuiu os animais. Os camelos, observou um pregador em 1696, foram sensatamente colocados na Arábia, onde não havia água, e as bestas selvagens "enviadas a desertos, onde podiam causar menos dano". Constituía um sinal da Providência Divina que os animais selvagens fossem menos prolíficos que os domésticos e que vivessem em covis durante o dia, geralmente saindo apenas à noite, quando os homens dormiam. Além disso, enquanto os indivíduos das espécies selvagens são muito parecidos entre si, as vacas, os cavalos e outros animais domésticos apresentam uma variação muito conveniente de cor e forma, providenciada para que "o homem pudesse distingui-los mais prontamente e saber de quem eles são propriedade".
\end{abstract}

A noção de diversidade, portanto, seria fruto de uma força criadora incontestável e harmoniosa, que teria legado ao homem tudo o que existe no planeta, e por alguma razão. Foi somente no séc.XIX, com a publicação de Origem das Espécie, de Darwin em 1859 e, pouco tempo mais tarde, com os trabalhos de Mendel, publicados nos anos de 1860, que a explicação para a diversidade biológica contou com o surgimento das primeiras noções de evolução e genética.

Com o estudo destas novas ciências e o desenvolvimento tecnológico, as décadas subsequentes observaram a minimização da abrangência do criacionismo e da ideia do Homem como espécie "escolhida". Seria uma questão de tempo até que o ser humano percebesse a necessidade de preservar o meio ambiente, a fim de garantir sua própria sobrevivência.

\footnotetext{
${ }^{1}$ TOULMIN, G.H. A antiguidade e duração do mundo. Londres, 1780. Ed. de 1824.
} 


\subsection{A NECESSIDADE DE PRESERVAR}

Desde há muito o ser humano é obrigado a reconhecer, mesmo que apresente ressalvas, que não pode seguir utilizando indiscriminadamente os recursos que o planeta lhe apresenta. A ideia de que a Terra seria uma fonte inesgotável de água potável, ar limpo e terras férteis, entre outras dádivas ditas "divinas", perpetrada por mitos antigos sobre a criação do mundo em muitas culturas - e não uma prerrogativa judaico-cristã, ao contrário do que se pensa (LEEMING, 2005; SARNA, 1997) - foi paulatinamente cedendo lugar à dúvida, que incentivou estudos científicos, substituiu a noção de um mundo criado para o desfrute do homem, e trouxe à baila e à mesa de discussão da sociedade uma questão chave: a espécie humana sobreviverá por quanto tempo mais, se continuar exaurindo e extenuando a Natureza?

Em meados do século passado e em vista de fortes evidências científicas (como o buraco na camada de ozônio, e fenômenos como a inversão térmica e as ilhas de calor), a sociedade passou a entender, após duas grandes guerras e defronte à imensa destruição ocasionada por elas - especialmente depois dos episódios lamentáveis de Hiroshima e Nagasaki - que havia muito a se fazer para tentar reverter o processo de dilapidação ao qual o planeta estava sendo submetido por ela mesma.

Essa ideia tomou forma, mais precisamente, em 1972, com a publicação do relatório do MIT "Os Limites do Crescimento" (The Limits to Growth), onde cinco variáveis (população mundial, industrialização, poluição, produção de alimentos e esgotamento de recursos) foram examinadas em um modelo matemático computacional. O resultado gerou um alerta, sentenciando o crescimento econômico mundial a zero, se quiséssemos evitar um colapso social, econômico e natural (LIMA, 2009; MACKENZIE, 2012).

No mesmo ano da publicação do livro supracitado, houve a Conferência de Estocolmo, onde 113 países (aliados a cerca de 400 instituições governamentais e não governamentais) confabularam sobre preservação da natureza e desenvolvimento sustentável, definindo que (Princípio 2, UNEP, 1972, tradução nossa): 
Os recursos naturais da Terra, incluindo o ar, a água, a terra, a flora e a fauna e especialmente as amostras representativas dos ecossistemas naturais devem ser preservados para o benefício das gerações presentes e futuras, através de planejamento e administração cuidadosos, como apropriado.

Também foi declarado, na mesma conferência, que (Princípio 4):

O homem tem a responsabilidade especial de preservar e administrar com sabedoria o patrimônio da fauna e do seu habitat, que está atualmente em grave perigo por uma combinação de fatores adversos. A conservação da natureza, incluindo a vida selvagem, deve receber importância no planejamento para o desenvolvimento econômico.

Alguns anos mais tarde, em 1987, o documento intitulado "Our Common Future" (ou, como é comumente chamado, Relatório Brundtland), escrito pela Comissão Mundial sobre Meio Ambiente e Desenvolvimento da ONU, trouxe em seu Anexo 1 (Resumo Das Propostas De Princípios Legais Para Proteção Ambiental E Desenvolvimento Sustentável, Aprovada Pelo Grupo De Peritos WCED De Direito Ambiental):

\footnotetext{
Estados-Membros devem manter os ecossistemas e os processos ecológicos essenciais para o funcionamento da biosfera, devem preservar a diversidade biológica, e devem observar o princípio do rendimento ótimo sustentável no uso dos recursos naturais vivos e ecossistemas. (UN, 2012)
}

Outras conferências e documentos de igual importância surgiram a seguir, como a Agenda 21 (1990), o Protocolo de Quioto (com vigência a partir de 2005) e a Declaração de Gaia (2009), corroborando a urgência do desenvolvimento sustentável e da preservação da diversidade no planeta. Durante este processo, as sociedades foram obrigadas a entender que não é o planeta quem precisa ser salvo, mas a espécie humana.

Bradar que um globo de 12.756,28 km de diâmetro equatorial, achatado em seus polos, com cerca de 4,5 bilhões de anos de idade, envolvido em uma atmosfera de aproximadamente $1000 \mathrm{~km}$ de espessura e portando um volume de água de 1,59 bilhões $\mathrm{km}^{3}$ (NASA, 2012; USGS, 2012) deve ser salvo por uma espécie extremamente adaptada - e que, justamente por isso, perece quando suas condições limitantes são minimamente modificadas - com uma média de vida que raríssimas vezes ultrapassa os 100 anos (ou $10^{7}$ vezes menor que a idade do 
planeta), soa onipotente e distante da realidade. Por isso, não convence. Ainda assim, em determinados momentos da História, foi possível comprovar o poder de destruição dos seres humanos ao causarem um desequilíbrio inominável ao meioambiente. Permanecem, como testemunhas silenciosas destas ocasiões, os resíduos nucleares dispensados em tambores no fundo do oceano, as explosões na área de testes de Nevada, durante o Projeto Manhattan, metais pesados resultado de processos de beneficiamento de minérios em condições irresponsáveis ou mesmo o descarte diário de toneladas de lixo industrial em corpos de água.

Felizmente, conforme os estudos científicos avançaram, assumiu-se que a espécie humana depende muito mais de outras espécies e do ambiente que a circunda e fornece os recursos, do que jamais se acreditou. Muitos foram compelidos ao erro de considerar o planeta um armazém de usufruto próprio, em grande parte por uma ideia criacionista romântica e ingênua. Porém, entende-se hoje que a espécie humana representa somente mais uma espécie em uma cadeia trófica; que esta cadeia tem suas bases em formas de vidas por vezes muito simples (e ainda assim, maravilhosamente complexas, como uma briófita); que estas vidas se correlacionam em um delicado equilíbrio interdependente; que todos estes sistemas são moderados pela quantidade de insolação, de evaporação, de precipitação, do substrato e das rochas que, degradadas no intemperismo de centenas a milhares de anos, o forma.

Conclui-se, inevitavelmente, que não há um "planeta a ser salvo", mas que a geo-bio-diversidade deve ser preservada, para que a espécie humana continue tendo chances de sobrevivência.

\subsection{BIODIVERSIDADE VERSUS GEODIVERSIDADE?}

A princípio representada somente por manifestações bióticas, a necessidade de conservação da diversidade foi ganhando importância e espaço tanto na comunidade científica como na mídia, quando se tomou consciência da importância dela e de sua rápida diminuição devido à atividade humana. Essa preocupação em preservar tanto o habitat quanto as espécies motivou convenções importantes a partir da década de 1970. Durante a década seguinte, a expressão "diversidade 
biológica" foi reduzida para "biodiversidade" e se tornou um forte sinônimo de diversidade (GRAY, 2004).

Essa noção criou raízes profundas e angariou a simpatia da opinião pública, em parte devido à campanhas publicitárias que tencionavam chocar o espectador, utilizando-se ad libitum de imagens fortes - e, sob o ponto de vista atual, um tanto equivocadas - perpetradas por organizações de caráter preservacionista, como o Greenpeace. Devido a essa movimentação midiática, o senso comum absorveu a ideia de que era preciso preservar os "bichos e as plantas".

O conceito de diversidade sempre priorizou a biota, pois, conforme dizem Crawford \& Black (2012), são com as formas vivas que tendemos a simpatizar e relacionar com a nossa própria natureza. A situação foi bem definida por Milton (2002), ao dizer que "a diversidade da natureza é geralmente compreendida como a diversidade da natureza viva". Esquecidos ficaram outros elementos igualmente importantes para a diversidade, como o solo, as rochas, as pessoas e sua interação com o ambiente que manipulam e do qual retiram sua subsistência.

Bernáldez (1985) justifica esta tendência através da seleção natural, por meio da qual teríamos desenvolvido a predisposição de enxergar o que se move e não prestar muita atenção ao que não se move, movidos pelo instinto de defesa. Assim, segundo o ecólogo, estaríamos predispostos a não enxergar os elementos geológicos.

Segundo Gray (2004), o embrião de um conceito de geodiversidade já havia vingado e dava seus primeiros sinais de vida no começo do séc XIX: a primeira reserva geológica da Alemanha foi definida em 1836, o Parque Nacional de Yellowstone foi fundado em 1872 e houve um caso de ação legal para preservar Salisbury Crags, na Escócia, em 1819. Ou seja, ainda que, no imaginário popular, a identidade da diversidade se dê mais com a biota do que com as manifestações geológicas, houve quem enxergasse ambas com igual importância na preservação do planeta.

É possível que o termo "geodiversidade" tenha sido usado por iniciativa e analogias próprias de cientistas da terra, em vários locais, muito antes de seu primeiro uso oficial, em 1993, quando foi citado durante a Conferência de Malvern sobre Conservação Geológica e Paisagística (GRAY, 2004). Sua utilização, portanto, não data de mais que 20 anos (SILVA, 2008). 
Durante este período, vários autores tentaram se aproximar de uma definição mais exata do que seria a geodiversidade. No entanto, tanto o termo quanto seu significado não encontraram ainda formatação, tampouco implementação consistente, mesmo entre os profissionais da área de Ciências da Terra (BRILHA, 2005). Não há um consenso quanto ao caráter e quantidade de variáveis que compõem a geodiversidade e a questão persiste, pendular, ora admitindo a presença do elemento antropogênico e suas manifestações sociais e culturais, ora a excluindo totalmente do âmbito da discussão; por vezes adicionando a influência biogênica em seu aspecto mais amplo, por vezes a ignorando completamente.

Eberhard (1997), por exemplo, definiu a geodiversidade como "a diversidade natural entre aspectos geológicos, do relevo e dos solos", enquanto Stanley (2001) a conectou à sociedade, aproximando o povo e sua cultura da diversidade ambiental e geológica do local. Stanley ainda foi mais longe, colocando a biodiversidade como parte integrante da geodiversidade, considerando que entender a relação entre as duas é imprescindível para que se possa conservá-las (STANLEY, 2002).

O início da década de 2000 assistiu ao debate do tema e à reivindicação dos geocientistas, que procuravam delimitar um conceito de geodiversidade que fosse aceito pela comunidade científica de todas as áreas e que abrangesse os elementos e processos geológicos. Gray (2004) mostrou que a situação era mundial, com ápices nos locais onde a ideia de preservação era mais presente: Austrália, Reino Unido e Estados Unidos. Pemberton (2001) atribuiu esta dificuldade da comunidade científica, do governo e das agências de conservação da natureza em englobar os elementos geológicos e geomorfológicos na definição de diversidade e em não ignorá-los como base para os processos bióticos, devido à falta de treino dos profissionais de Ciências da Terra em teoria, políticas e prática em geoconservação.

Paulatinamente se foi assentando uma ideia de comum essência, de que a geodiversidade abrange os processos e fenômenos geológicos e geomorfológicos que dão base para a vida no planeta. Em 2002 a Australian Heritage Comission assumiu a definição de Sharples (Tab 3.4). Importante adicionar que, no mesmo ano, Sharples (2002) complementaria sua definição, declarando a necessidade de se diferenciar os conceitos de geodiversidade (a qualidade do que se pretender conservar), geoconservação (o esforço para conservar a geodiversidade) e 
patrimônio geológico (exemplos concretos de elementos da geodiversidade que apresentam necessidade significativa de conservação).

Dois anos antes, em 2000, Gray utilizou o termo no título de um artigo e a Royal Society for Nature Conservation (RSNC) o adotou para seu periódico que foi lançado em janeiro de 2001 (mas terminou abruptamente um ano depois).e em cuja primeira edição, Stanley lança a pergunta: "o que é geodiversidade?". A resposta engloba a ligação entre as pessoas, paisagens e culturas (Tab. 3.4).

No entanto, a definição que a RSNC adotou e que figura em diversas referências exclui o elemento antropogênico seus desdobramentos sociais e culturais. Brilha (2005) cita a definição da RSNC e a adota como sendo:

A variedade de ambientes geológicos, processos e fenômenos ativos, que dão origem a paisagens, rochas, minerais, fósseis, solos e outros depósitos superficiais, que são o suporte para a vida na Terra.

Mais recentemente, Gray (2008) comenta que o termo tem sido cada vez melhor aceito e começa a ser utilizado em projetos e produções governamentais, como é o caso do primeiro Plano de Ação Nacional para a Geodiversidade, no Reino Unido ou a Scottish Natural Heritage, que utilizou a palavra largamente em seu livro sobre geologia e relevo da Escócia em 2007, intitulado Land of Mountain and Flood. A tabela 3.4, modificada de Nikitina (2012), apresenta um breve histórico das definições mais importantes de geodiversidade, desde 1995.

No Brasil, o Serviço Geológico - CPRM (2006) publicou a seguinte definição, que foi adotada neste trabalho, para nortear o presente inventário na llha de São Sebastião:

O estudo da natureza abiótica (meio físico) constituída por uma variedade de ambientes, composição, fenômenos e processos geológicos que dão origem às paisagens, rochas, minerais, águas, fósseis, solos, clima e outros depósitos superficiais que propiciam o desenvolvimento da vida na Terra, tendo como valores intrínsecos a cultura, o estético, o econômico, o científico, o educativo e o turístico. (SILVA, 2008, p.34) 


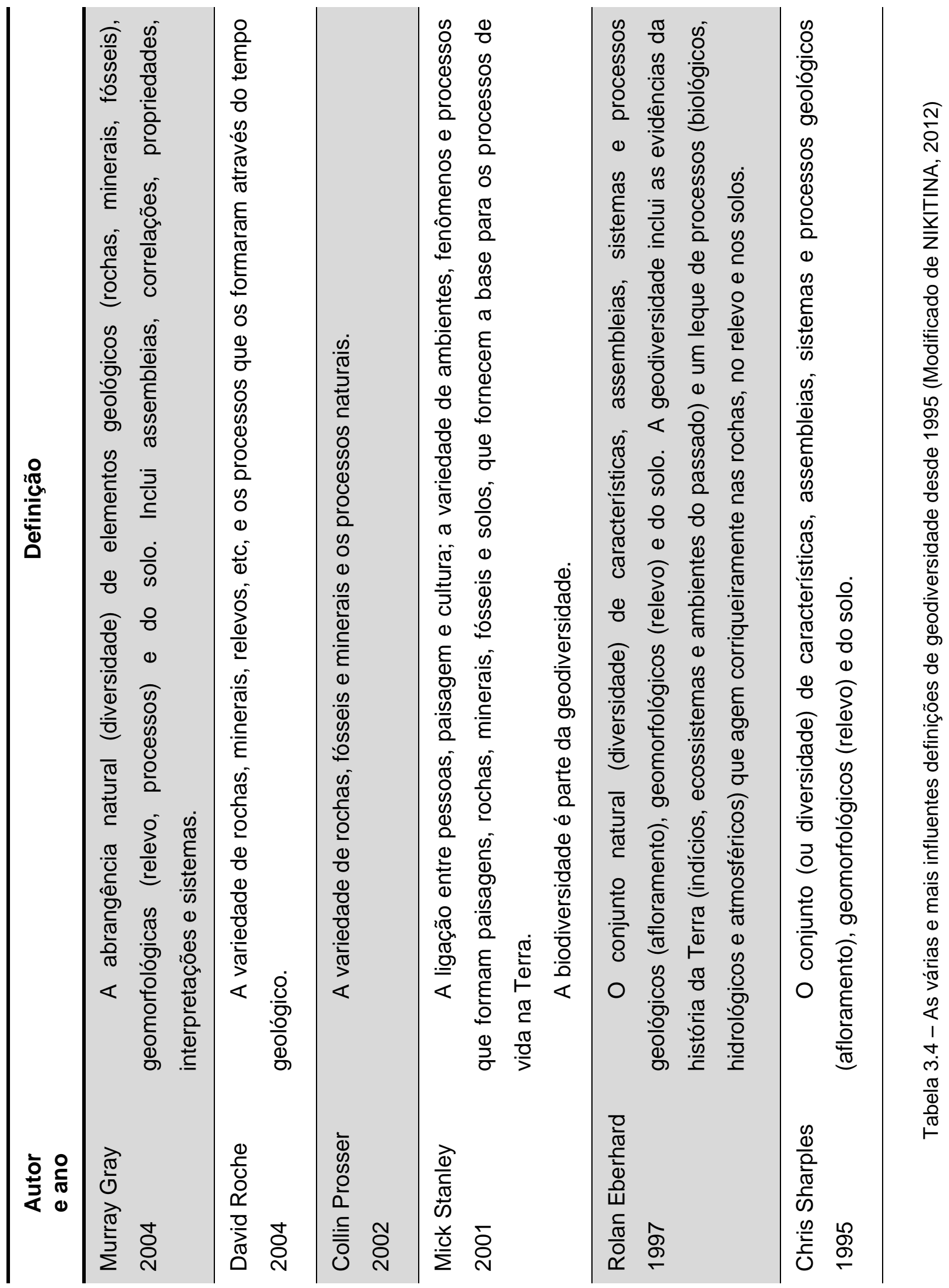




\subsection{PATRIMÔNIO GEOLÓGICO: QUANDO A GEODIVERSIDADE DEVE SER CONSERVADA}

As palavras utilizadas para definir cada um dos elementos desta área de patrimônio geológico têm sido utilizadas com certa desenvoltura por acadêmicos. No entanto, quando as definições de cada um desses termos são confrontadas, percebe-se que há um universo de possibilidades semânticas, que não necessariamente são percebidas por dois interlocutores, discutindo sobre o assunto e recorrendo ao jargão. Tencionando assegurar o bom entendimento deste capítulo e da discussão que pretendemos, torna-se necessário definir as palavras mais usadas na área: geodiversidade, geoconservação e patrimônio geológico.

\subsubsection{Geodiversidade}

Usar-se-á a definição supracitada do Serviço Geológico do Brasil - CPRM (2006):

O estudo da natureza abiótica (meio físico) constituída por uma variedade de ambientes, composição, fenômenos e processos geológicos que dão origem às paisagens, rochas, minerais, águas, fósseis, solos, clima e outros depósitos superficiais que propiciam o desenvolvimento da vida na Terra, tendo como valores intrínsecos a cultura, o estético, o econômico, o científico, o educativo e o turístico. (SILVA, 2008, p.34)

Esta definição acopla quatro dimensões à geodiversidade: i) os ambientes, fenômenos e processos; ii) os elementos (rochas, minerais, águas, fósseis, solos, clima e depósitos superficiais); iii) o desenvolvimento da vida no planeta e iv) os valores (intrínsecos a cultura, o estético, o econômico, o científico, o educativo e o turístico).

Os valores integrantes da definição são os componentes abstratos intrínsecos do elemento da geodiversidade que se pretende aquilatar e que nos causam o sentimento de urgência em proceder à preservação. Para Brilha (2005), "o ato de proteger e de conservar algo se justifica porque lhe é atribuído algum valor".

Quando esta ideia é aplicada à conservação de um elemento da geodiversidade, torna-se necessário definir qual o caráter deste valor que está 
sendo atribuído ao elemento, para que se possa aquilatar a real necessidade de uma possível intervenção (se emergencial, se incisiva, e de que natureza) e para que se consiga observar e valorar o elemento com o máximo de objetividade possível.

\subsubsection{Geoconservação}

Como se somente a sobrevivência biológica e física da espécie humana não bastasse, as culturas variadas com as quais o planeta é povoado nutrem a premente necessidade de preservação da identidade, através da sua história. Segundo François Hartog (2006), o patrimônio, como memória da história, se torna um vetor de identidade. E assim, tão lógico quanto pretendeu-se proteger as evidências dos processos os quais a espécie humana vivenciou, desde hominídeos ou antes, até Homo sapiens sapiens, tão lógico o é fazer-se o mesmo com as evidências históricas da Terra e com a sua diversidade.

Inúmeros elementos de geodiversidade seriam, então, registros importantes e ilustrativos dos eventos e processos relevantes da história da Terra e, sob este ponto de vista, suas conservação e gestão apresentam enorme interesse para a humanidade. (PEREIRA; BRILHA; MARTINEZ, 2008).

Sharples (2002, p.2) define o objetivo da geoconservação como sendo:

a preservação da diversidade natural (ou geodiversidade) de significativos aspectos e processos geológicos (substrato), geomorfológicos (formas de paisagem) e de solo, mantendo a evolução natural (velocidade e intensidade) desses aspectos e processos.

Esta definição, embora muito aceita pela comunidade acadêmica, não esclarece um equívoco comum e que causa toda a sorte de problemas: conservação não é preservação. Conservação, para Burek e Prosser (2008), é o "gerenciamento ativo de algo, de modo a garantir que sua qualidade seja retida". A ideia de conservação, no entanto, é comumente distorcida e transformada em algo parecido com "não utilizar mais o que se pretender preservar, para que o objeto não seja prejudicado (ou estragado)".

Essa noção equivocada do que é a geoconservação pode trazer inúmeros problemas, especialmente quando há a intenção de sagrar algum elemento da 
geodiversidade como "patrimônio geológico". Como exemplo, tomem-se os relatos orais sobre tentativas de destruição do elemento a ser preservado, por indivíduos que temeram perder "seus terrenos", "suas plantações", ou até o acesso à suas casas.

A geoconservação deve promover a gestão e o uso sustentável da geodiversidade sempre. Não se pode esquecer que o ser humano não está isolado da geodiversidade e depende dela para seu sustento e a manutenção de suas atividades (BRILHA, 2005). Assim, é impossível conceber a geoconservação isolada da sociedade.

O intuito do presente trabalho encontra bases sólidas na definição de Geoconservação apresentada por Burek \& Prosser (2008): "uma ação tomada com o objetivo de conservar e enaltecer características geomorfológicas, processos, sítios e espécimes".

Um dos pilares da Geoconservação é a conservação de locais e ocorrências que tenham valor geológico ou que testemunhem fortemente alguma das facetas da geodiversidade (Crawford \& Black, 2012). Contudo, não se costuma preservar ou enaltecer o que não se conhece. Por isso, para conservar é necessário que primeiramente se proceda ao reconhecimento, estudo e valoração destes locais de forma sistematizada e utilizando parâmetros que permitam a comparação e classificação não somente absoluta, mas também relativa a outros locais no resto do mundo.

\subsubsection{Patrimônio geológico}

Das noções de geoconservação expostas e as considerações subsequentes, decorre a conclusão de que há que se conservar certos elementos da diversidade "que são dotados de qualquer tipo de valor superlativo que se sobrepõe à média". (BRILHA, 2005). Estes são o que se costuma designar patrimônio geológico (Fig.3.5.3).

As definições de Brilha (2005), Gray (2004) e da CPRM (2006) convergem para dizer que patrimônio geológico é o elemento da geodiversidade que apresenta inegável valor científico, pedagógico, turístico, cultural, ou outro, e que por isso deve ser conservado e protegido, para não ser extraviado. Gray adiciona que a 
geoconservação existe para evitar a perda do elemento da geodiversidade, mas não é feita sem pesquisa de campo e "georestauro", que, juntos, devem procurar a manutenção e a melhora do elemento a ser preservado.

De um modo geral, podem-se relacionar os três conceitos da seguinte forma (Gray, 2004): Geodiversidade é a qualidade a ser conservada; geoconservação é o esforço para fazê-lo, e patrimônio geológico contempla exemplos concretos daquilo que foi interpretado como tendo importância de conservação.

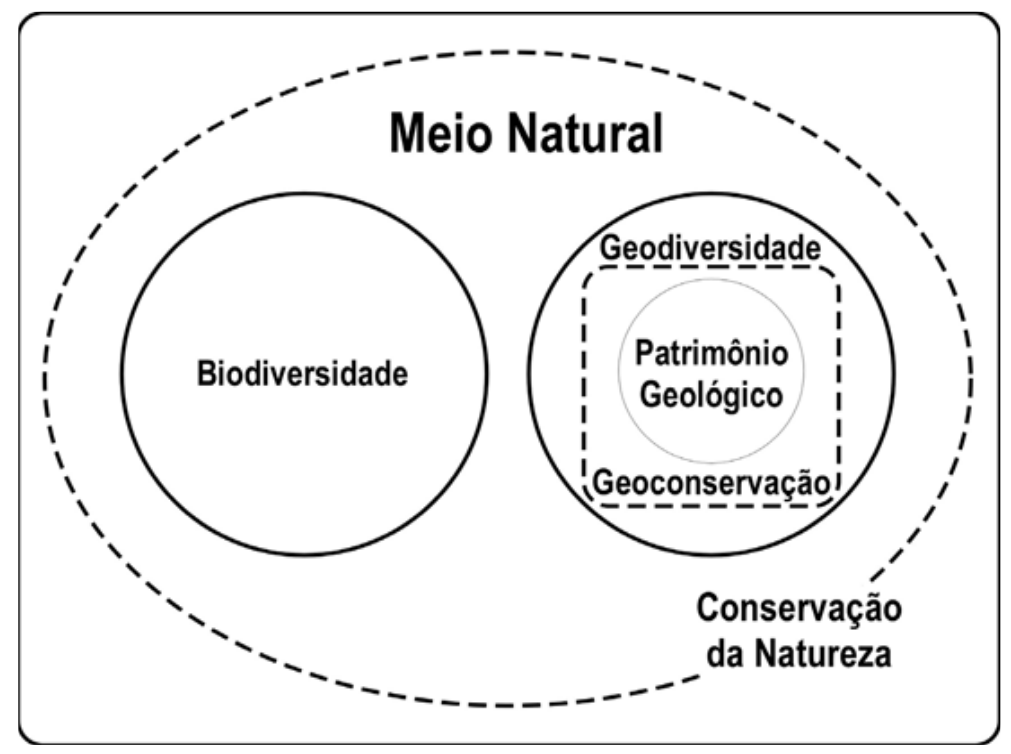

Figura 3.5.3 - Dentre todos os elementos da geodiversidade, somente aqueles que apresentam características que se sobressaem em valor cultural, educativo ou outro, são considerados patrimônio geológico. (PEREIRA, 2010)

Pode-se fazer uma analogia interessante para ilustrar melhor a questão, comparando a geodiversidade à coleção de joias de uma mulher. A geoconservação, seria a manutenção destas joias, que a mulher faz cuidadosamente, sem no entanto deixar de usá-las. Ela, porém, não as utiliza para ir a qualquer lugar, e com qualquer roupa, mas as combina com o que veste e as apropria à ocasião. O patrimônio geológico é, portanto, nesta analogia, cada uma das peças mais valiosas da coleção. O valor de cada uma é diferente: uma pulseira que ela ganhou em uma ocasião especial; um anel de diamante de alto quilate; um colar de ouro que foi assinado por um estilista famoso, ou até mesmo um par de brincos de quartzo rutilado onde o arranjo não intencional das fibras do metal no interior do cristal a faz enxergar um coração. A mulher certamente não usará 
qualquer uma destas joias para ir às compras de supermercado, fará a manutenção de cada peça cuidadosamente e as guardará de modo que não se estraguem. Mas não deixará de usá-las em uma festa ou um jantar.

Para definir um elemento como patrimônio geológico, é necessário proceder à avaliação sistemática da geodiversidade do local, seguindo um método de inventário e quantificação previamente determinado e que atenda às necessidades e características específicas do local e do contexto social e cultural. Diversos autores têm se preocupado em definir métodos de inventário do patrimônio geológico que sejam os mais objetivos possíveis. Há muitos já publicados, porém todos os modelos ainda carregam forte dose de subjetividade, mesmo que apresentem fórmulas para cálculos por vezes bastante rebuscadas.

Um passo de suma importância e prévio ao inventário propriamente dito é a definição de um framework, (ou categoria temática, que será definida pela comunidade acadêmica envolvida no processo e seguindo valores científicos). Assim, pode-se definir um framework ou vários no mesmo inventário, e eles servirão para balizar quais elementos da geodiversidade serão incluídos na lista de geossítios. Um exemplo de framework são as unidades geológicas ou eventos geológicos importantes da região perscrutada.

A investigação também é balizada por um ou mais valores da geodiversidade, que servirão de linha mestra para a avaliação desta. Gray (2004) define os valores da geodiversidade em seis vertentes que se completam para construir uma definição mais consistente dela: intrínseco, cultural, estético, econômico, funcional, científico e educativo (Tab. 3.5.3).

Por valor intrínseco, pode-se entender o valor de uma manifestação da geodiversidade, pura e simplesmente por sua existência, sem adicionar nenhum valor utilitário ao homem. O valor cultural, no entanto, adiciona ao elemento da geodiversidade um significado social ou comunitário (folclórico histórico ou arqueológico, por exemplo). O valor estético, mais tangível, se refere ao apelo visual. Por econômico, entende-se, de maneira bastante simplificada, o valor comercial e monetário (GRAY, 2004).

O valor funcional da geodiversidade pode ser visto segundo duas perspectivas (GRAY, 2004; BRILHA, 2005): in situ, de caráter utilitário para o homem e como pilar de sustentação para processos físicos e ecológicos. Por fim, os valores 
científico e educativo são o que define a importância do estudo e da interpretação da geodiversidade como evidência da história do planeta e cujo estudo exerce um papel importante na formação profissional do educando.

A definição de um framework pode auxiliar na obtenção de alguma objetividade durante $\mathrm{o}$ inventário. Por outro lado, por mais que se trabalhe visando 0 contrário, o inventário sempre pode ser fortemente prejudicado pela subjetividade inerente ao processo e da qual não se consegue isentar completamente, especialmente se for feito por um grupo de pessoas, com cada uma visitando e avaliando um local diferente.

\begin{tabular}{|c|c|}
\hline Valor & Significado \\
\hline Intrínseco & $\begin{array}{l}\text { O mais subjetivo. Remete à ligação com as perspectivas } \\
\text { filosóficas e religiosas de cada sociedade e cultura. }\end{array}$ \\
\hline Cultural & $\begin{array}{l}\text { Quando se reconhece uma forte interdependência entre o ser } \\
\text { social e o mundo físico que o rodeia. }\end{array}$ \\
\hline Estético & $\begin{array}{l}\text { Subjetiva e não passível de quantificação. } \\
\text { É o "bonito", "belo", "agradável". }\end{array}$ \\
\hline Econômico & $\begin{array}{c}\text { Inerente a elementos da geodiversidade como os recursos } \\
\text { minerais, energia geotérmica e eólica, e minerais radioativos, } \\
\text { por exemplo. }\end{array}$ \\
\hline Funcional & $\begin{array}{l}\text { O valor da geodiversidade in situ, de caráter utilitário para o } \\
\text { Homem, ou } \\
\text { O valor da geodiversidade como substrato para os sistemas } \\
\text { físico e ecológicos na Terra }\end{array}$ \\
\hline $\begin{array}{l}\text { Científico } \\
\text { e educativo }\end{array}$ & $\begin{array}{l}\text { A geodiversidade utilizada para investigação científica e uso } \\
\text { pedagógico. }\end{array}$ \\
\hline
\end{tabular}

Tabela 3.5.3 - Os valores da geodiversidade, segundo Brilha (2005)

O valor que orienta este trabalho de pesquisa é o científico e o framework é a história geológica da região costeira do estado de São Paulo, no contexto da evolução do Supercontinente Gondwana. No entanto, Ilhabela é uma estância 
turística e uma de suas principais atrações é a Pedra do Sino. Muito embora o ponto mencionado não seja strictu sensu um afloramento, pois a procedência dos matacões não é exata, ainda assim é de extrema importância para o geoturismo e a economia local e por isso, foi necessário considerar, em uma segunda varredura, o valor turístico, aplicando-o onde necessário. 


\section{GEOSSÍTIOS}

A seguir, são apresentados os locais selecionados como geossítios.

A respeito destas descrições, decidiu-se por um modelo que pudesse facilitar a visualização das características essenciais de cada local, de modo que qualquer um que resolvesse estudar os geossítios pudesse ter uma visão geral de seus elementos de geodiversidade e importância mesmo sem visitá-los.

É válido também lembrar que as descrições normalmente feitas para os inventários procuram contar com referências e trabalhos acadêmicos sobre as litologias estudadas e que, por isso, são citadas por vezes à exaustão, recurso que pouco pôde ser usado neste caso. Como já descrito no cap. 1, a abordagem desta pesquisa partiu do levantamento bibliográfico que não é vasto, tampouco detalhado sobre a geologia pontual da ilha, seguindo-se da consulta a professores e pesquisadores que conheciam a área, para iniciar os trabalhos de campo com direcionamento.

O levantamento feito nestes campos é preliminar, podendo ser acrescido de outros geossítios conforme novas investigações sobre a área forem feitas, pois como a ilha apresenta cobertura vegetal cerrada e topografia com muitos desníveis, não é possível acessar com liberdade o substrato rochoso, que, em sua maioria, se encontra escondido (GARCIA et al. ${ }^{1}$, 2014). Não obstante os percalços, foi possível selecionar e descrever pontos onde as características da rocha ilustram o framework que orienta este inventário: a história geológica da região costeira do estado de São Paulo, mais precisamente no que concerne à sua evolução geodinâmica em termos de Supercontinente Gondwana.

Ainda não há disponível um mapeamento geológico mais detalhado do que 0 da escala 1:750.000, do Serviço Geológico Brasileiro (PERROTTA et al., 2005). Assim, decidiu-se localizar os geossítios em imagens do software online Google Maps, utilizando as coordenadas obtidas em campo, com um único ponto central de referência, tanto nos geossítios pontuais como nos do tipo "perfil". Na figura 4.1

1 GARCIA, M.G.M; MARTINS, L.; DEL LAMA, E.A.; BOUROTTE, C. O inventário do patrimônio geológico da região costeira do estado de São Paulo: base metodológica, adaptações e considerações. P aceito para o 47ํㅡㄹ Congresso Brasileiro de Geologia, Salvador, 21 a 26 set 2014. 
estão indicados todos os geossítios deste trabalho, a fim de permitir sua localização espacial na ilha e em relação uns aos outros.

Para finalizar esta introdução, é preciso dizer que não é possível, neste momento, delimitar a área exata de cada um dos geossítios sugeridos, pois esse processo deve levar em consideração as legislações (ambientais, municipais, estaduais e também nacionais, já que as praias são bens pertencentes à União) que regulam o território estudado, bem como a ocupação humana e as atividades desenvolvidas no local. Sabemos, no entanto, que a delimitação de um geossítio é condição sine qua non para se proceder à geoconservação, através da implementação de estratégias de gestão. Não é o escopo deste trabalho, apesar de, no cap. 6 serem apresentadas sugestões neste sentido.

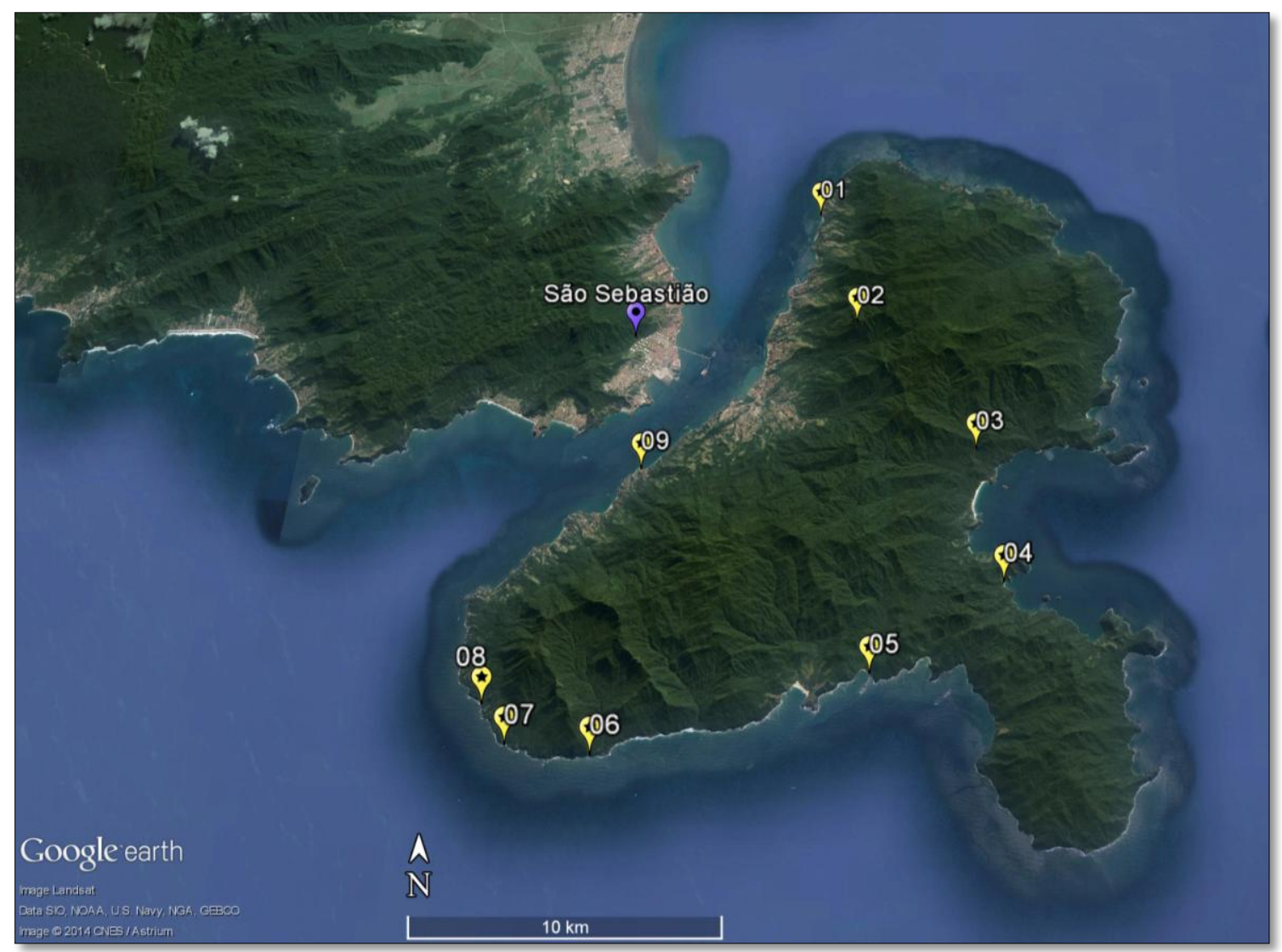

Figura 4.1 - Localização pontual dos geossítios da llha de São Sebastião: 1- Pedra do Sino, 2- Pico do Baepi, 3- Cachoeira do Gato, 4- Praia da Figueira, 5- Praia de Enchovas, 6- Buraco do Cação, 7- Diques da Ponta da Sela, 8- Gabros Estratiformes e 9- Portinho. 


\subsection{GEOSSÍTIO PEDRA DO SINO}

Localização (UTM):0464465/73733788 (Fig. 4.1.1)

Tipo: Pontual

Acesso: Rodovia SP-131, localmente denominada Av. Leonardo Reale, 3752. Passarelas construídas pelo restaurante do local dão acesso direto aos dois blocos mais importantes do local, sendo um deles a principal "Pedra do Sino".

Dimensão: blocos grandes dispostos aleatoriamente ao longo de cerca de $140 \mathrm{~m}$ de costa e avançando alguns metros pelo mar (Fig. 4.1.2).

Unidade dentro do mapa da CPRM (2006): O geossítio está localizado na praia, em local que coincide com o que o mapa da CPRM acusa como NPccgm (unidade granito-gnáisscamigmatíticahornblenda-biotita gnaisse granitoide porfiróide e augen gnaisse, de idade entre 647 e $578 \mathrm{Ma}$ - U-Pb). Porém, estes blocos rolados tiveram sua origem no maciço sienítico, de topologia mais alta, cuja unidade no mapa é K2 $\lambda$ se (complexo plutônico alcalino São Sebastião: nordmarkito; nas bordas dos stocks, sienito, localmente sienitonefelínico. Idade: $81 \mathrm{Ma} \mathrm{Rb}-\mathrm{Sr}$ ).

Justificativa do valor científico: Foi incluído no inventário pelo intenso apelo turístico relacionado à geologia e por ser um dos raros locais de fácil acesso com a presença de fonolitos.

Elementos principais de interesse: O local não pode ser caracterizado como um afloramento geológico per se, pois consiste em uma área de cerca de $140 \mathrm{~m}$ de blocos rolados de grandes dimensões, cuja origem não é determinada claramente.

O litotipo predominante é uma rocha alcalina - segundo Pileggi ${ }^{2}$ (2013), nefelina sienito. As caneluras, padrão de intemperismo típico de rochas alcalinas, são bem pronunciadas, especialmente nos blocos que se encontram dentro do mar. No imaginário popular, as caneluras "parecem ter sido cavadas com uma

2 PILEGGI, F. Banco de Dados Petrográficos dos Geossítios do Litoral Norte do Estado de São Paulo. Iniciação Científica - em andamento. 
colher" ou "arranhadas por uma onça" (comunicação oral com turistas e moradores locais). Não há explicações definitivas na literatura para a causa deste padrão de intemperismo, embora a hipótese mais aceita seja ainda a de processos químicos causados pela água da chuva que, ácida e escorrendo pela superfície da rocha, causa a dissolução seletiva de alguns minerais. Em rochas alcalinas félsicas, especialmente em nefelina-sienitos e fonolitos, a nefelina é lixiviada, produzindo cavidades na superfície da rocha (MOTOKI et al. 2007).

A coloração dos blocos parcialmente submersos é diferente daquela dos blocos que são atingidos pela água somente quando a maré sobe. Os que ficam sujeitos a este intemperismo causado pela água do mar por um maior espaço de tempo apresentam marcadamente, além da coloração acinzentada original, porções mais escuras e porções róseas (Fig.4.1.3).

O tamanho dos blocos varia e alguns chegam a ter aproximadamente 5 metros em sua maior extensão. Muitos deles já se encontram fraturados pelos intemperismos físico, químico e biológico. Neste caso, podem-se observar as duas porções do bloco separadas por alguns centímetros, mas ainda assim mantendo o padrão da quebra, mostrando perfeitamente como se encaixavam. Nestas fraturas é que costumam ocorrer evidências de intemperismo biológico, especialmente de vegetação que se aproveita do espaço para galgar à luz (Fig. 4.1.4a). Os blocos menores parecem ser mais trabalhados - exibem arredondamento - ou são partes fraturadas de blocos maiores, que despencaram e ainda conservam arestas pronunciadas. Ao se observar cuidadosamente os blocos, pode-se aferir o padrão de quebra de alguns dos pedaços e imaginar a posição original deles (Fig. 4.1.4b).

Não há trabalhos científicos sobre as características mineralógicas, geoquímicas e outras destas rochas em específico; somente de outras porções da ilha, onde a rocha, mesmo sendo alcalina, não apresenta essa particularidade sonora. Ainda assim, podemos supor que estes blocos tenham rolado do alto do maciço alcalino Serraria, por dois motivos: i) a localização deste ponto está nas proximidades da base do maciço; e ii) a composição alcalina da rocha, que faz com que acreditemos que o maciço possa ser a rocha-fonte.

O fenômeno que esses blocos apresentam, soando como sinos de igreja ao serem percutidos com uma ferramenta de metal ou outro pedaço de rocha, é digno de nota. A revisão bibliográfica não acusou nenhum estudo sobre a causa desta 
sonoridade. Os motivos mais prováveis podem ser a compacidade da rocha, que promoveria melhores condições para a propagação de ondas sonoras (TAIOLI, 2012, informação verbal ${ }^{3}$ ) ou a posição dos blocos no afloramento, com pontos de apoio tais que reproduzissem as condições de um litofone (MEDINA, 2012, informação verbal ${ }^{4}$ ) ou, ainda, as duas condições conjugadas.

As características sonoras desta rocha foram utilizadas didaticamente na tentativa de construção de um litofone no trabalho de graduação de Campos (2013), que descreveu a rocha como sendo holocristalina, leucocrática (cinza) com textura porfirítica. Pileggi (2013) aponta um nefelina sienito e observa, em seções delgadas, uma rocha de textura inequigranular seriada, com megacristais de plagioclásio zonado e nefelina e cristais finos e outros muito finos de feldspato potássico e nefelina.

O local tornou-se ponto turístico importante (senão o mais importante) da região e é chamado de Pedra do Sino, apesar de ser, na verdade, a Praia de Garapocaia. A "Pedra do Sino" propriamente dita são dois blocos maiores onde finalizam as duas passarelas que foram construídas pela prefeitura. (Fig. 4.1.5). Durante a execução deste trabalho, em conversa com moradores locais (caiçaras), soubemos que uma rocha aparentemente similar é comumente chamada de "pedra ferro" pela comunidade, pois, ao ser cortada em blocos menores e percutida, emite um som metálico.

Em vista dos motivos expostos acima, não podemos justificar este ponto com tendo relevância científica como os outros deste inventário. Porém, a existência desta rocha "musical" é um dos principais motivadores do intenso turismo local. A Pedra do Sino suscita a curiosidade dos mais de 30.000 visitantes anuais (na alta temporada) e a vontade de aprender mais sobre as características geológicas da região. Isto faz deste ponto um local bastante propício para a exploração educativa do tema.

Outros tipos de interesse: Cultural. Há duas crendices relacionadas à Pedra do Sino. Na primeira, diz-se que em idos de1647, certa noite, a população foi acordada por sons de sinos que repicavam, avisando a chegada de um navio pirata. Debelada a ameaça, depois de luta comandada pelo santo onomástico da ilha, São Sebastião,

\footnotetext{
${ }^{3}$ Informação fornecida pelo Prof. Dr. Fabio Taioli, Instituto de Geociências - USP, 2012.

${ }^{4}$ Informação fornecida pelo Prof. Dr. Nilberto Medina, Instituto de Física - USP, 2012.
} 
ninguém soube precisar de onde havia vindo o som que os prevenira. Os índios, então,apontaram para as pedras, dizendo "garapocaia, garapocaia!".

A segunda lenda inicia-se da mesma maneira, com os moradores sendo despertos pelo repicar de sinos. Ao chegar à praia, viram um caixão com quatro (ou seis, as versões divergem) velas descendo o canal em direção ao Sul, com a imagem de Bom Jesus, que foi depois encontrada em lguape e onde é venerada como Bom Jesus da Cana Verde (SIMÕES, 2005; PREFEITURA DE ILHABELA, 2012).

Uso potencial: Turístico e Didático.

Vulnerabilidade: Natural baixa. Antrópica moderada: o restaurante fornece uma marreta para que os turistas martelem a rocha e escutem o som metálico. Isso é feito de forma repetida, geralmente com força e por muitas pessoas na alta temporada (Fig. 4.1.6a / b e b, e 4.1.7a / b). Apesar da resistência da rocha, este hábito nos leva a prever a quebra de pedaços da rocha em longo prazo. Em um cenário bastante pessimista, se o som da Pedra do Sino for causado pela combinação de compacidade, forma do bloco e pontos de apoio, não sabemos como a eventual quebra poderá afetar a produção de som.

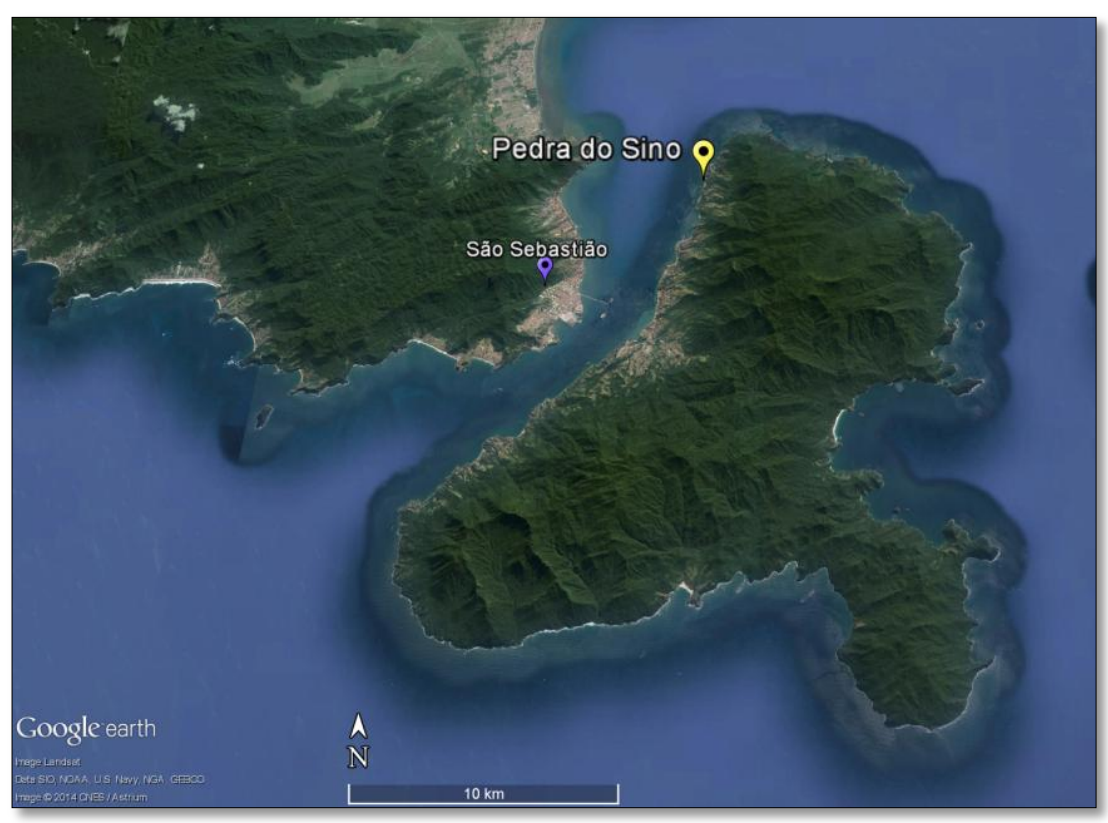

Figura 4.1.1 - Localização do geossítio Pedra do Sino na llha de São Sebastião. 


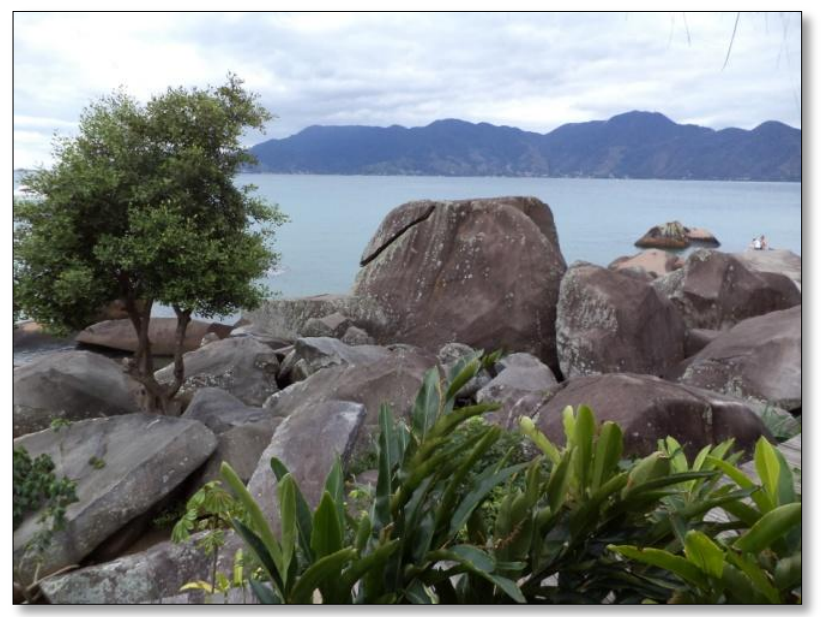

Figura 4.1.2 - Afloramento visto de dentro do restaurante. Os blocos são atingidos pelas ondas e parcialmente submersos quando a maré sobe.

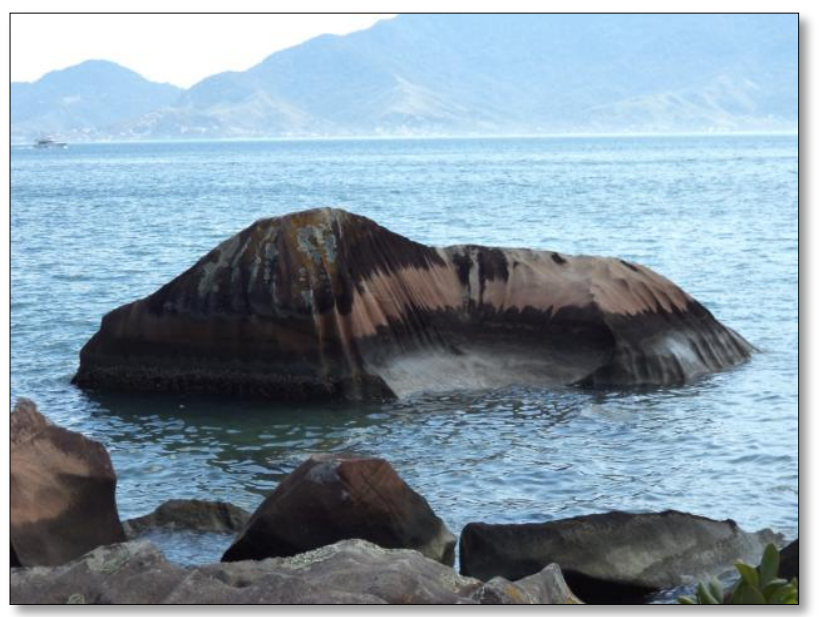

Figura 4.1.3 - Os blocos que ficam mais tempo em contato com a água do mar apresentam caneluras mais pronunciadas e certa coloração rósea, que os difere dos blocos não alcançados pela água.

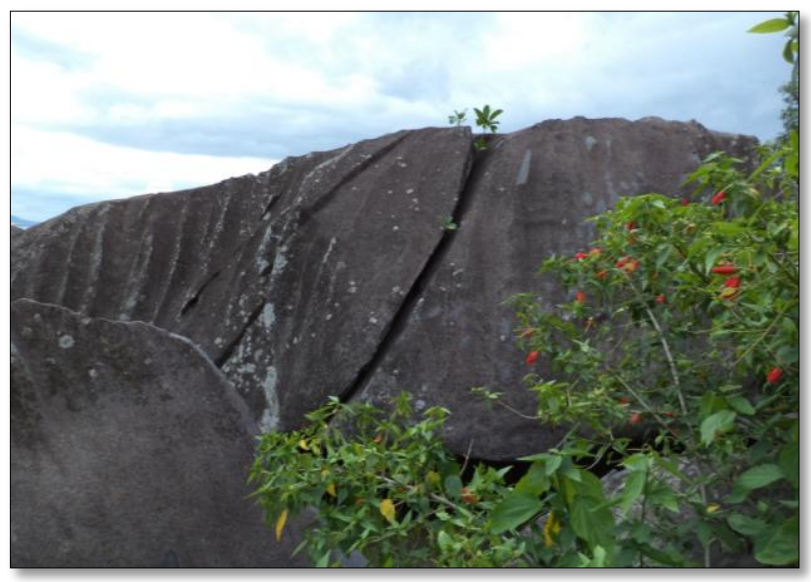

Figura 4.1.4a - Alguns blocos maiores apresentam-se rachados. A vegetação aproveita o menor espaço que se abra para procurar luz, causando, com o tempo, uma separação ainda maior entre os dois pedaços (intemperismo biológico). 


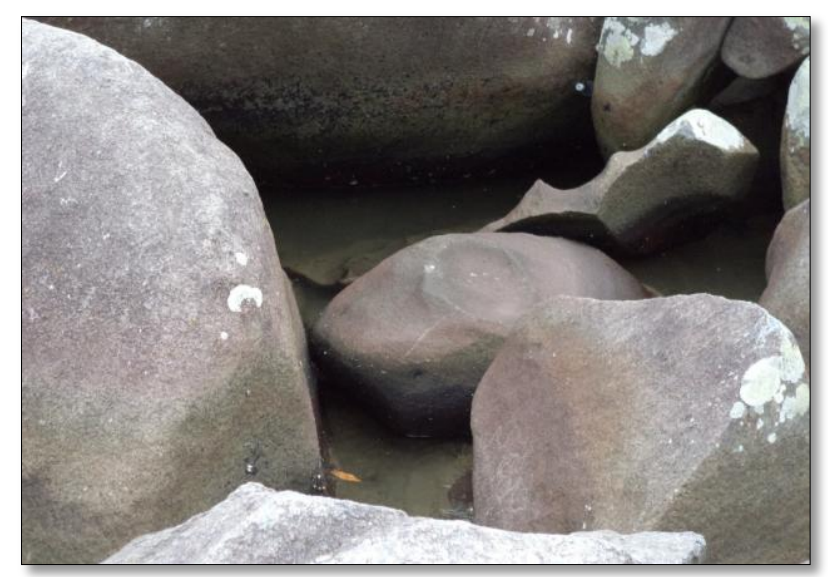

Figura 4.1.4b - Alguns blocos apresentam arestas e pouco arredondamento; outros já se encontram bastante retrabalhados. No afloramento todo a diferença de dimensões entre os blocos é notável.

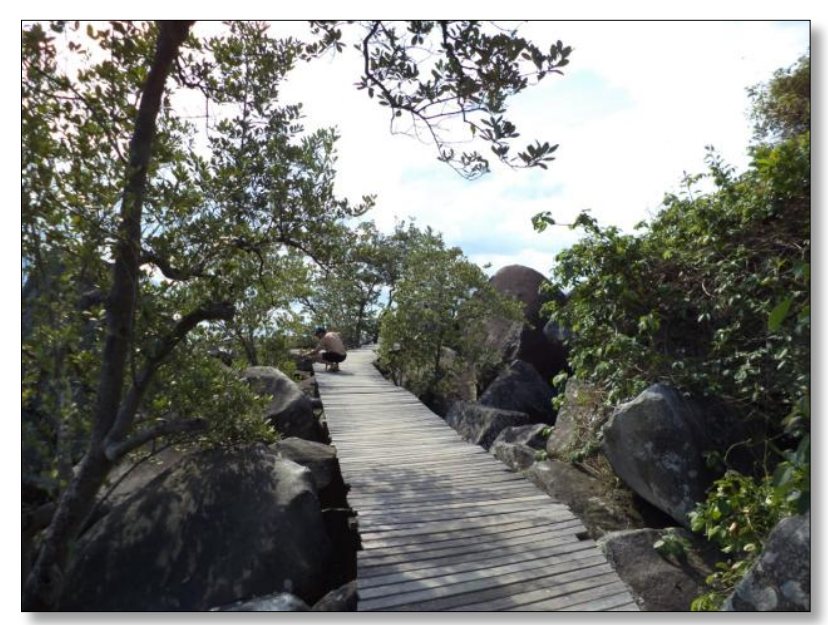

Figura 4.1.5 - O restaurante do local instalou duas passarelas que levam aos dois blocos mais sonoros do afloramento.

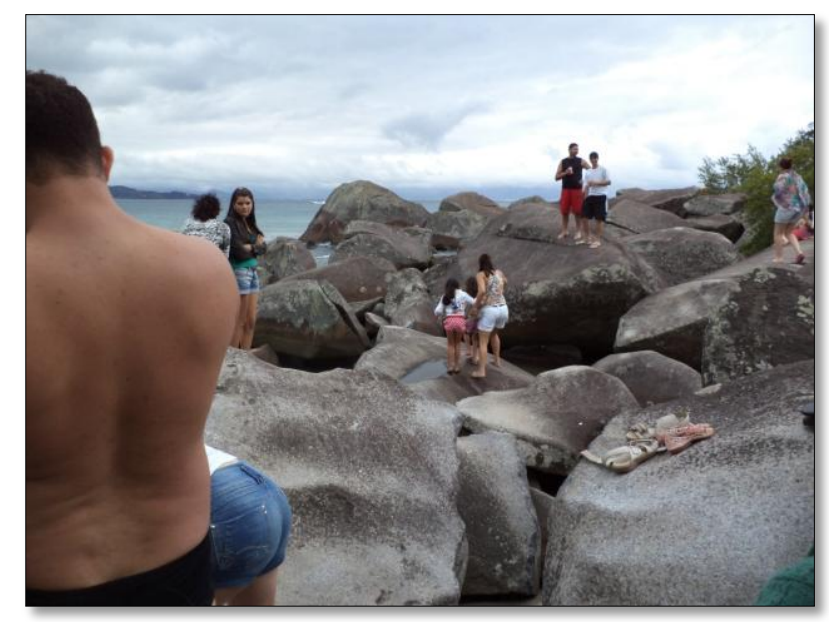

Figura 4.1.6a - Em um momento de alta temporada, a visitação ao local é intensa. As pessoas sentem-se curiosas a respeito do som e das formas diferenciadas dos blocos e ficam um longo tempo tecendo hipóteses. 


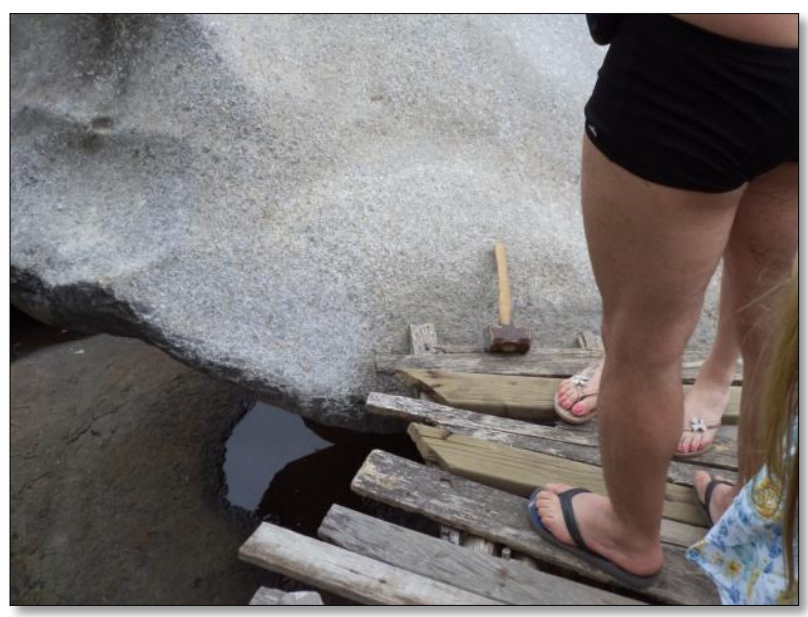

Figura 4.1.6b - A marreta oferecida pelo restaurante passa de mão em mão. Todos ficam ávidos para martelar a rocha e produzir o som metálico.

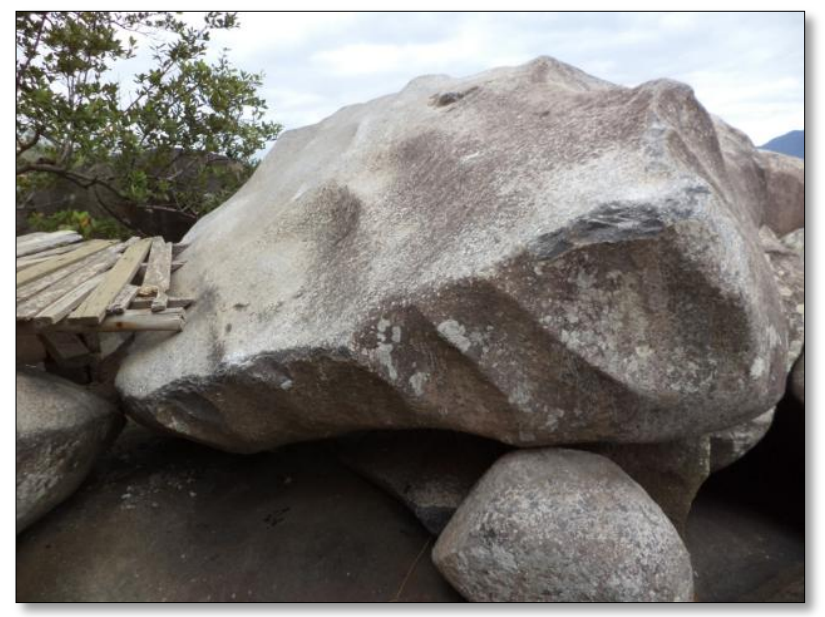

Figura 4.1.7a - A principal Pedra do Sino, ao final da passarela. Pode-se observar que suas bordas estão lascadas devido aos golpes repetidos de marreta pelos turistas.

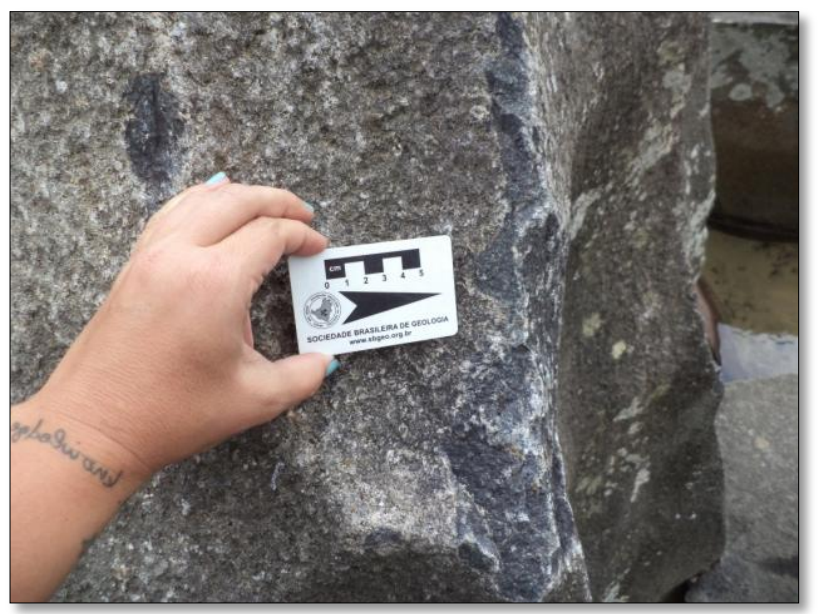

Figura 4.1.7b - Os turistas ficam empolgados com o som metálico e utilizam a marreta fornecida pelo restaurante para bater em outros blocos, a fim de investigar se eles também produzem som. Nesta foto, outro bloco do afloramento também foi lascado pelo mesmo processo. 


\subsection{GEOSSÍTIO PICO DO BAEPI}

Localização (UTM): laje sul: 0466197 / 7368625, laje norte: 0466154 / 7368709 (Fig. 4.2.1)

Tipo: Pontual

Acesso: A trilha que leva ao cume tem sua entrada no bairro do Itaguaçu, nas coordenadas 0463762/7367595 e é mantida pelo Parque Estadual de Ilhabela (Fig. 4.2.2). Apesar da constante manutenção (muitas vezes terceirizada para empresas especializadas unicamente nesse objetivo) a trilha apresenta nível de dificuldade alta e o acompanhamento por monitor credenciado pelo PElb é obrigatório. Tem 7,4 km de extensão, alta declividade em vários pontos e leva às duas lajes do topo, sendo a mais alta (Laje Sul), de 1048m de altitude.

Dimensão: piso de rocha de cerca de $150 \mathrm{~m}^{2}$ na Laje Sul e de cerca de $300 \mathrm{~m}^{2}$ na Laje Norte.

Unidade dentro do mapa da CPRM (2006): K2גse - Complexo plutônico alcalino São Sebastião: nordmarkito; nas bordas dos stocks, sienito; localmente, sienito nefelínico. Idade: $81 \mathrm{Ma} \mathrm{Rb-Sr}$.

Justificativa do valor científico: Excelente mirante natural para observar e estudar a geomorfologia do litoral norte do estado, bem como para ilustrar os processos geológicos pós rifteamento

Elementos principais de interesse: O Pico do Baepi é o ponto mais alto do maciço alcalino Serraria, ao Norte da ilha.

No início da trilha podem ser vistos blocos rolados de rocha vulcânica com fenocristais de plagioclásio e durante o trajeto encontram-se blocos de sienito. A partir de cerca de $700 \mathrm{~m}$ de altitude, os blocos de rochas tornam-se raros, a vegetação predomina e se torna densa. A inclinação e dificuldade da trilha aumentam e para atingir o cume é necessário primeiro cruzar agachado um bambuzal extenso e logo em seguida, galgar um terreno difícil, com rochas íngremes e pouco solo, tornando-se necessário agarrar-se às raízes, por vezes, para subir. 
As rochas voltam a aparecer completamente nas duas lajes do cume, pois a cobertura vegetal escasseia devido à falta de substrato; porém se encontram bastante alteradas pela exposição contínua aos agentes de intemperismo. A inferência óbvia é que sejam rochas alcalina do maciço.

O local é um importante mirante natural, de onde se podem observar e estudar a geomorfologia de uma extensa área do litoral do estado de São Paulo, bem como inferir os processos que estão aliados às geoformas. Da laje norte, de maior dimensão e piso mais horizontal, é possível enxergar, em dias claros e sem nebulosidade, a llha de Alcatrazes, pontos do litoral de Caraguatatuba e até Ubatuba (Fig. 4.2.3a /b / c / d).

A Serra do Mar é interpretada por Almeida \& Carneiro (1998) como um "grande fronte dissecado de falhas em que termina o Planalto Atlântico". Segundo os autores, o embasamento costeiro apresenta rochas e estruturas que ilustram os 3 eventos de amalgamação continental - os supercontinentes Atlântida (Paleoproterozóico), Rodínia (Mesoproterozóico) e Gondwana Ocidental (ao final do Neoproterozóico). Cada evento de amalgamação foi seguido de processos de quebra do continente, trafogênese, rifteamento e episódios de magmatismo anorogênico e sedimentação intracratônica. Por isso, durante a quebra do Gondwana, no Mesozóico, inúmeras falhas e fraturas foram reativadas. O controle litológico do relevo é bastante visível nessas zonas, com rochas menos resistentes, onde a erosão diferencial determinou a rede de drenagem; as escarpas são sustentadas por rochas com maior resistência, como os maciços alcalinos.

O final do Jurássico assistiu aos eventos magmáticos e tectônicos que culminaram na ruptura do Gondwana Ocidental e a abertura do Oceâno Atlântico no Cretáceo Inferior. O magmatismo toleítico intenso que antecedeu a quebra do supercontinente teve seu pico há ca. 132 milhões de anos. (MARQUES \& ERNESTO, 2004)

Acredita-se que o início dos processos que geraram a Serra do Mar se deu no Cretáceo, com o deslocamento da plataforma sul americana para oeste, sobre uma anomalia térmica, (que era difusa demais para ser chamada de hot spot e não era intensa o bastante para ser considerada uma pluma mantélica). Isto causou 0 soerguimento de uma "serra do mar cretácea" de $300.000 \mathrm{~km}^{2}$ de extensão, cujas 
bordas margeavam o que são atualmente as charneiras da Bacia de Santos e de Campos. Ainda no Cretáceo, houve a intrusão dos stocks alcalinos e a superfície de erosão Japi. Esta, que Riccomini et al (2004) dataram por derrame de lava alcalina em superfície em 65,65 \pm 0,05 Ma., aplainou o megaplanalto que se erguia a até $2.000 \mathrm{~m}$ acima do nível do mar e que era a principal área fonte de sedimentos das bacias adjacentes, de Campos, de Santos e do Paraná (ALMEIDA \& CARNEIRO, 1998; RICCOMINI et al. 2004; ZALAN \& OLIVEIRA, 2005). Assume-se que o término do aplainamento da superfície Japi tenha acontecido entre o final do Cretáceo e o início do Paleógeno (HIRUMA et al., 2010).

A situação deste megaplanalto era isostaticamente instável e foi dirimida através do colapso gravitacional de blocos, com a formação de corredores de grabens subparalelos à costa - que Almeida (1976) chamou de Sistema de Rifts da Serra do Mar e Riccomini (1990) denominou Rift Continental do Sudeste do Brasil (ZALAN \& OLIVEIRA, 2005). O rift continental, segundo Riccomini et al (2004), foi originado no Paleógeno resultado da reativação, como falhas normais, de zonas de cisalhamento neoproterozóicas.

Almeida \& Carneiro (1998), situam o surgimento das escarpas da Serra do Mar concomitante à deformação da Superfície Japi por falhamentos e flexuras, no Paleoceno. Este evento tectônico deu origem às bacias tafrogênicas do sudeste e à Serra da Mantiqueira, bem como fez soerguer o bloco ocidental da Falha de Santos e abater o oriental, dando efetivamente origem à Serra do Mar. Nas três ou quatro dezenas de milhões de anos seguintes, a Serra sofreu erosão diferencial regressiva, recuando até $40 \mathrm{~km}$, entalhando a superfície Japi e deixando ilhas próximas ao litoral.

Estas ilhas, completam Almeida \& Carneiro (1998), subsistiram à erosão devido à resistência de algumas rochas, especialmente dos corpos alcalinos que suportaram as grandes altitudes dos Picos do Papagaio, de São Sebastião e do Baepi, na ilha de São Sebastião, por exemplo.

Dividindo o litoral brasileiro em setores, Ab'Saber (2000) diz que, por ser estabelecido em rochas cristalinas, o litoral norte do estado de São Paulo é o mais recortado do país, sendo possível observar uma sequência sucessiva de baías e enseadas, com feixes de restingas em seus fundos, e separados por esporões florestados da Serra do Mar. 
Analogamente, Silveira ${ }^{1}$ (1964, apud SUGUIO, 2003) classifica a parte do litoral brasileiro que vai do sul do Espírito Santo à região de Laguna (e, portanto, engloba o litoral norte de São Paulo), como sendo o "litoral sudeste ou das escarpas cristalinas", com duas características principais: a presença de lagunas costeiras e 0 escudo cristalino que chega até a orla litorânea, representado por escarpas de falhas de até $800 \mathrm{~m}$, originadas no Pré Cambriano e reativadas em vários momentos da evolução geológica desta porção do continente e, finalmente, recuadas por erosão. De um modo geral, embora ocorram sedimentos terciários, é o escudo cristalino que define as feições gerais, delimitando as planícies litorâneas em trechos restritos com o que Silveira denomina "praias-de-bolso".

Souza (2006), tendo estudado o litoral norte, reconhece ambientes em sua maioria holocênicos a atuais "distribuídos em planícies costeiras e praias pequenas bordejadas por encostas íngremes da Serra do Mar, onde se desenvolvem depósitos continentais restritos". Devido ao pequeno porte dos rios, suas planícies de inundação são restritas e as desembocaduras apresentam pequenos estuários, com planícies de maré isoladas.

Segundo Souza (2006.), há três compartimentações fisiográficas que margeiam o canal de São Sebastião: i) LCR: depósitos coluviais, tálus e leques aluviais constituídos de sedimentos de matriz areno-síltico-argilosa (holocênicos a atuais); ii) LMP: depósitos mistos (fluviais e coluviais de baixada não individualizados - holocênicos e atuais) e iii) LHT: depósitos marinhos constituídos de areias muito finas a médias, muito bem a moderadamente selecionadas (holocênicas) (Fig. 4.2.4).

A figura 4.2.5 exibe uma visão panorâmica do Pico do Baepi em julho de 2012.

Outros tipos de interesse: Cultural.

Uso potencial: Turístico e Didático.

Vulnerabilidade: Natural baixa. Antrópica baixíssima.

${ }^{1}$ SILVEIRA, J. D. Morfologia do litoral. In: AZEVEDO, A. (ed.) Brasil: a terra e o homem. São Paulo: Cia. Editora Nacional, p. 253-305, 1964. 


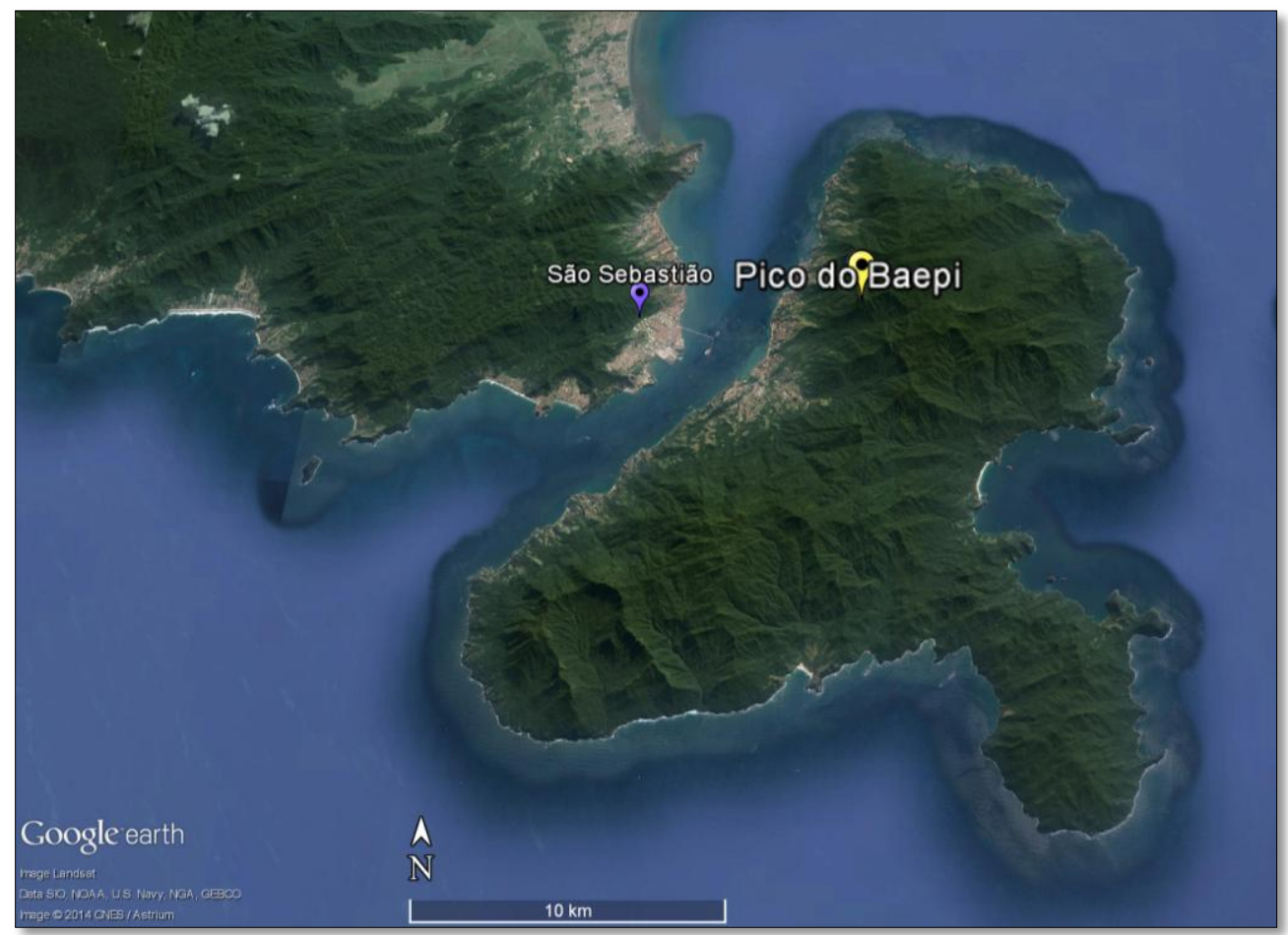

Figura 4.2.1 - O Pico do Baepi, no topo do maciço alcalino Serraria, ao norte da ilha. O pico apresenta duas lajes, sendo a sul, a mais alta, com $1048 \mathrm{~m}$ de altitude.

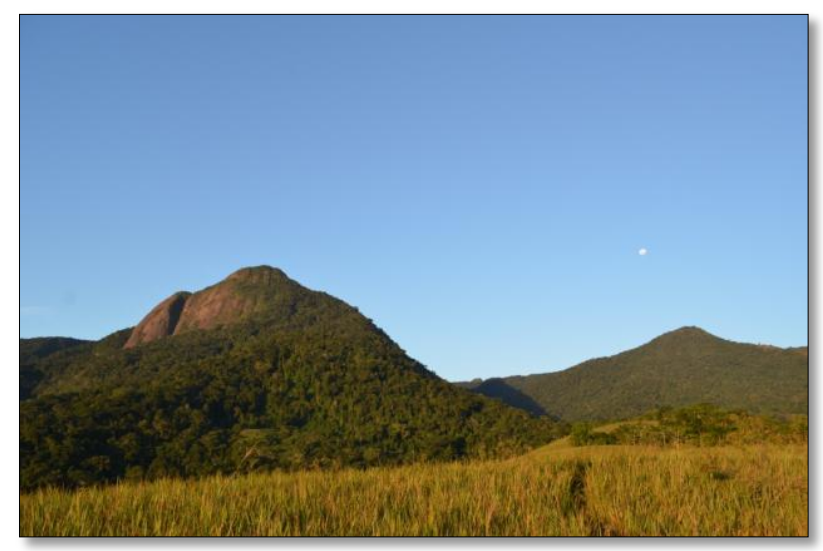

Figura 4.2.2 - O Pico do Baepi visto do ponto de início da trilha, ao final do dia. (Foto: Maria da Glória Motta Garcia) 


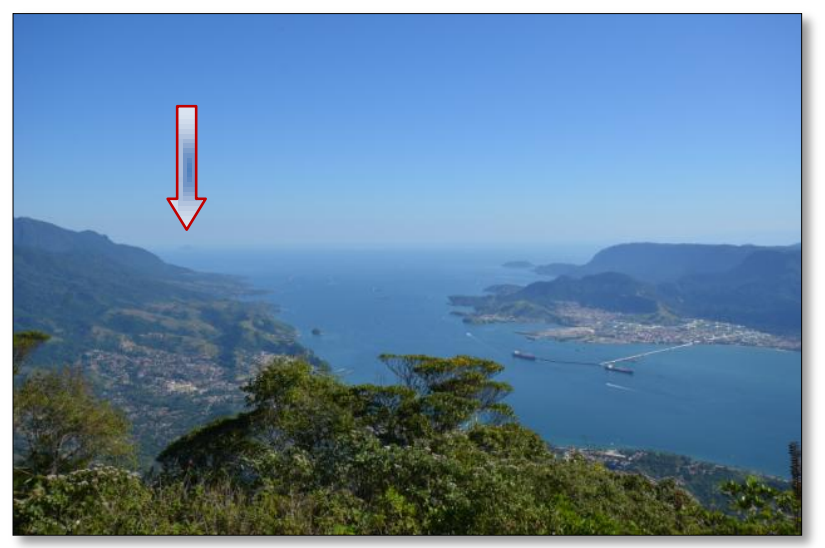

Figura 4.2.3a - A porção sul do canal de São Sebastião, avistado pela laje norte do Pico do Baepi. Ao longe, a silhueta da ilha de Alcatrazes (indicada pela seta). (Foto: Maria da Glória Motta Garcia)

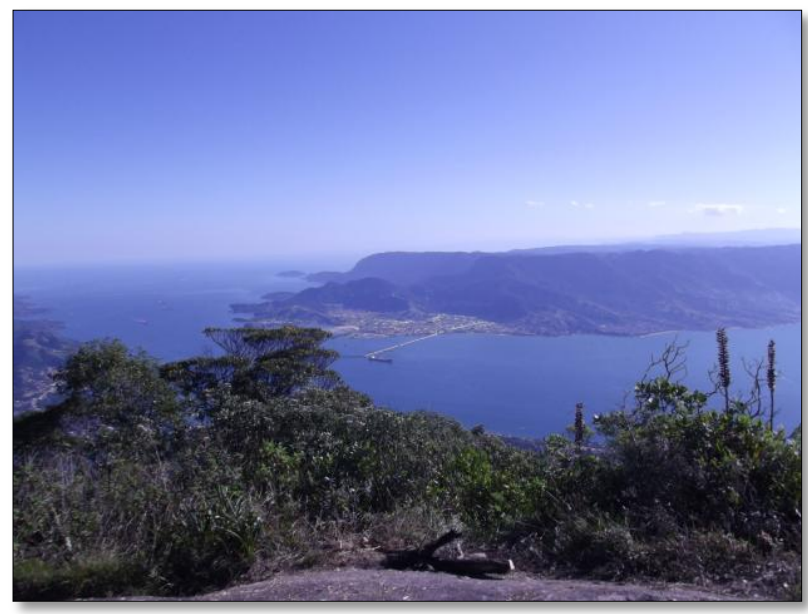

Figura 4.2.3b - A porção central do canal de São Sebastião e o porto, vistos da laje norte do Pico do Baepi. (Foto: Vanessa Mucivuna)

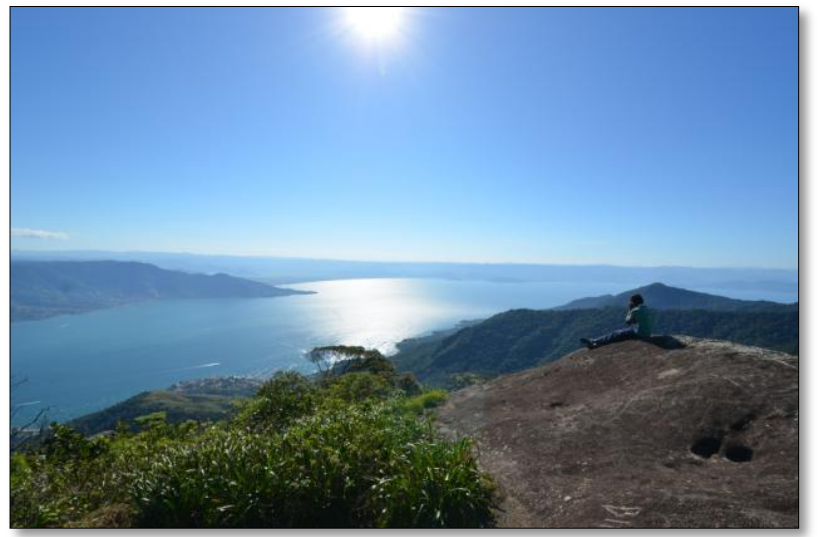

Figura 4.2.3c - A porção norte do canal de São Sebastião, vista da laje norte do Pico do Baepi, com o litoral de Caraguatatuba ao fundo. (Foto: Maria da Glória Motta Garcia) 


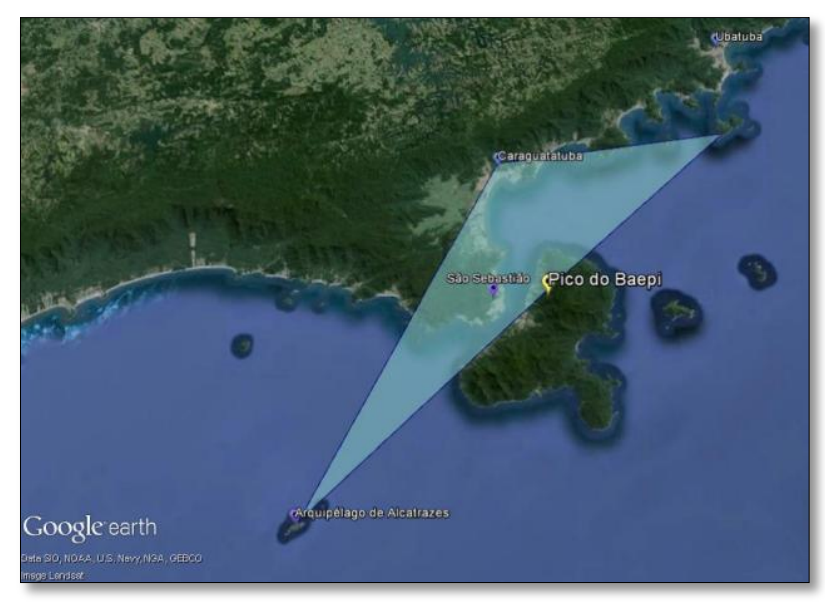

Figura 4.2.3d - Em condições de excelente visibilidade, a área passível de ser avistada do mirante natural que é o Pico do Baepi ultrapassa $800 \mathrm{~km}^{2}$, de acordo com os cálculos de área efetuados através do Google Earth.

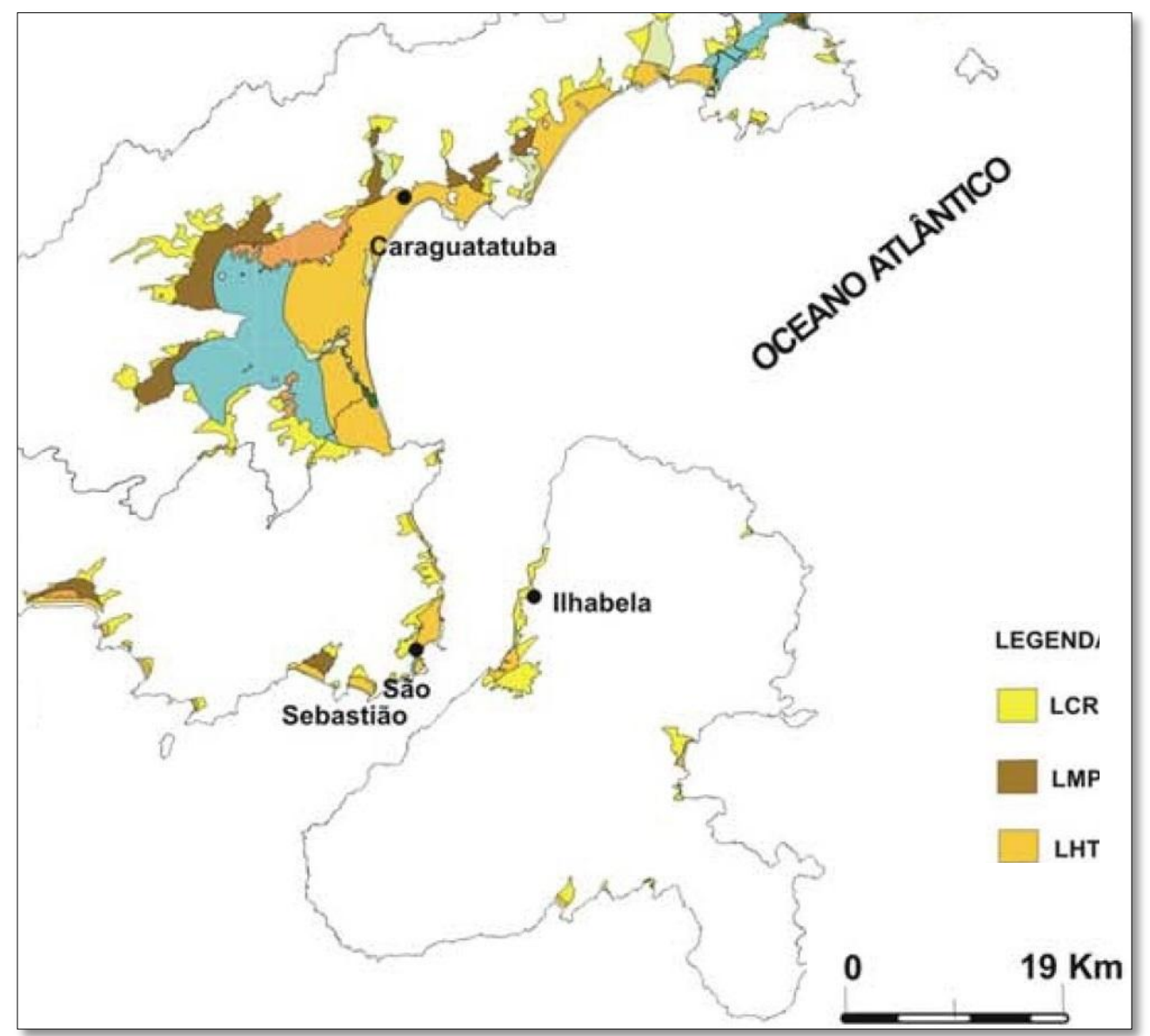

Figura 4.2.4 - Compartimentação fisiográfica de parte do litoral norte do estado de São Paulo (modificado de SOUZA, 2006). 


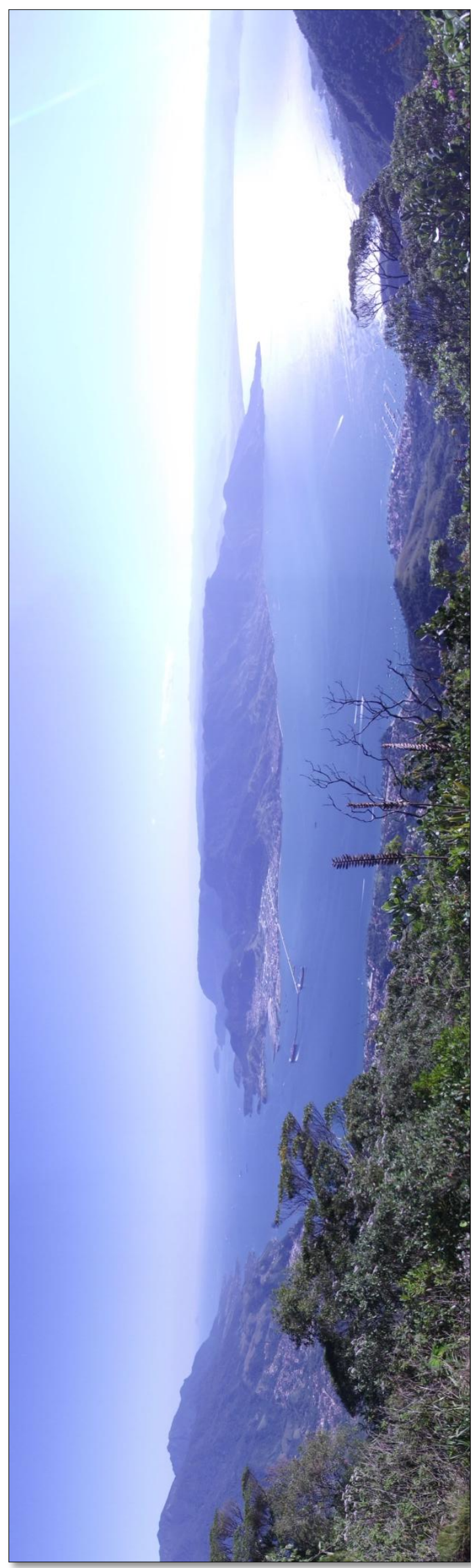

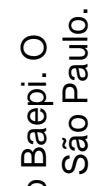

융

응응

음

응

흔

흠

즌

중 $\frac{\pi}{\frac{\pi}{\circ}}$

을

츙 이

สำ

요 $\frac{\pi}{0.0}$

$\frac{\pi}{5} \cdot \frac{\pi}{8}$

ช

क

잉

బ

응 응

주워ำ

ऽั

응 is

o

응

工

$\stackrel{0}{2}>$

$\stackrel{\pi}{=} \frac{0}{0}$

ญ 응 논

जँ

co 0

i。

닝 ํํํ

용

in

里

ชึ 2

要

흥

능

은유

홍

$>$ 을

เ 1 言

ํ

$\checkmark$

『ه

후 홍

离 


\subsection{GEOSSÍTIO CACHOEIRA DO GATO}

Localização (UTM): 0470661/7363660 (Fig. 4.3.1)

Tipo: Pontual

Acesso: através de trilha a pé, a partir do "Canto do Ribeirão" da Praia de Castelhanos (Fig. 4.3.2). A trilha tem extensão de cerca de $4.000 \mathrm{~m}$ e é considerada de dificuldade média, porém pode ser feita sem guia, embora dificilmente alguém o faça. Para chegar à Praia de Castelhanos, é necessário seguir em veículo off-road por uma trilha de terra bastante técnica, que corta a ilha e que tem início em uma guarita do PElb, no lado continental. A estrada tem horários regulados para ida e volta. Em dezembro de 2013 o PElb determinou um número máximo de veículos por dia (160), no intuito de minimizar os impactos causados pelo tráfego na estrada de terra e na praia pelo alto número de visitantes. Está em discussão a cobrança de taxa para o acesso à estrada.

Dimensão: trata-se de uma queda d'água com cerca de $50 \mathrm{~m}$ de altura, que alimenta uma piscina natural de cerca de $200 \mathrm{~m}^{2}$ (Fig. 4.3.3)

Unidade dentro do mapa da CPRM (2006): a localização no mapa faz crer que o paredão está localizado em NPccgm (unidade granito-gnáissico migmatítica hornblenda-biotita gnaisse granitoide porfiróide e augen gnaisse, de idade entre 647 e $578 \mathrm{Ma}$ - U-Pb). Porém, com a observação in situ do litotipo, há fortes indícios de

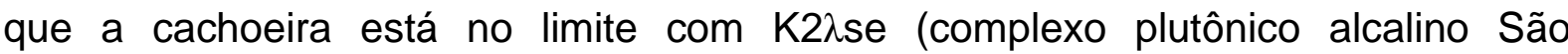
Sebastião: nordmarkito; nas bordas dos stocks, sienito; localmente, sienito nefelínico. Idade: $81 \mathrm{Ma} \mathrm{Rb}-\mathrm{Sr}$ ).

Justificativa do valor científico: É um raro afloramento de rocha alcalina de dimensões de centenas de metros na ilha. Apresenta remanescentes de diques e pode ajudar a ilustrar os processos que ocorreram após a intrusão dos stocks, nos eventos de magmatismo alcalino há cerca de $80 \mathrm{Ma}$, e mais recentes. Também auxilia a promover ilustração quanto à erosão diferencial. 
Elementos principais de interesse: A Cachoeira do Gato é um dos pontos turísticos mais importantes de Ilhabela. Sua trilha é de fácil acesso e o local apresenta uma passarela, instalada pelo PElb, para auxiliar o acesso à água doce. A queda d'água tem cerca de 50 metros e despenca por cima de um paredão de um tipo de rocha que os moradores locais costumam denominar "pedra sapo", formando uma piscina natural de fundo escorregadio que atrai muitos banhistas. A água então continua a escoar por outras quedas às quais o banhista não tem acesso devido à declividade acentuada e aos enormes blocos que ocupam todo o trajeto até o litoral (cerca de 1 km em linha reta) (Fig. 4.3.4a / b).

A rocha se encontra visível e descoberta pela vegetação e se mostra bastante alterada, estando à mercê dos agentes de intemperismo (Fig. 4.3.5). A observação da rocha fresca em ponto mais isolado mostra que é a mesma rocha que constitui os maciços alcalinos da ilha.

O afloramento apresenta os resquícios de um dique tanto no paredão da cachoeira quanto em seu canto inferior esquerdo (de orientação geral NE-SW) (Fig. 4.3.6a /b). Pode-se deduzir que a intrusão deste dique de grandes proporções tenha feito uso dos planos de fraqueza do corpo ígneo alcalino para intrudi-lo. Infere-se também que esta intrusão tenha auxiliado a formar a cachoeira, que acabou resultando da erosão diferencial do dique máfico e da outra parte constituinte do bloco original, simétrica à que contém o paredão, ao longo de muitos milhões de anos.

Trata-se de um dos raros afloramentos de rocha alcalina de proporções de centenas de metros quadrados de área cujo acesso é fácil, no lado oceânico da ilha. Também escassos são os locais onde há indícios de que os diques tenham cortado os corpos alcalinos, como ocorre neste geossítio.

Segundo Garda \& Schorscher (1996), os eventos de magmatismo da llha de São Sebastião são comumente divididos em três fases. A primeira coincide com o magmatismo da Bacia do Paraná, onde diques máficos de composição básica a intermediária, representados por lamprófiros, se estendem pelo litoral norte e provavelmente precedem os stocks (ca. $125 \mathrm{Ma}$ ). O caráter básico-ultrabásico alcalino dos lamprófiros difere do magmatismo alcalino de termos mais ácidos, (relacionado a traquitos e fonolitos) dos maciços de llhabela, (ca. $80 \mathrm{Ma}$ ). 
O terceiro magmatismo, hipoabissal a subvulcânico, produziu diques que cortaram os stocks alcalinos. Porém, há na literatura uma descrição (SILVA et al. ${ }^{1}$, 1977 apud GARDA \& SCHORSCHER, 1996) onde o maciço Serraria interrompe a N-NE um dique de andesito pórfiro. A investigação dos diques da Cachoeira do Gato pode, portanto, contribuir para determinar a que fase pertencem e as relações hierárquicas entre estes e o corpo alcalino.

Todas essas justificativas fazem da Cachoeira do Gato um objeto de estudos mineralógicos, geoquímicos e geocronológicos em potencial, para que se possa ajudar a elucidar as relações entre estes dois eventos de magmatismo de caráter distinto. Adicionalmente, poder-se-á investigar a colocação do dique no corpo alcalino e seu fluxo magmático, inferindo, assim, os processos tectônicos que deformaram a litosfera e posições relativas das fontes de magma e das fraturas, através dos estudos de anisotropia de susceptibilidade magnética (RAPOSO; DAGRELLA-FILHO; PINESI, 2007).

As relações hierárquicas e temporais aqui demonstradas, aliadas ao seu caráter ilustrativo de processos que formaram o litoral norte tal qual o conhecemos hoje faz com que este ponto apresente relevância científica e educativa.

Outros tipos de interesse: Turístico - os visitantes acessam o lugar para nadar na piscina natural.

Uso potencial: Científico, didático e turístico.

Vulnerabilidade: Natural baixa. Antrópica média a baixa, em relação ao lugar, que pode ser entulhado de lixo com o aumento da visitação sem estratégias de gestão. No entanto, devido às características da rocha, sua vulnerabilidade antrópica pode ser considerada baixíssima.

${ }^{1}$ SILVA, A.T.S.F.; CHIODI FILHO, C.; CHIODI, D.K.; PINHO FILHO, W.D. Projeto Santos - Iguape. v.1, Geologia. Convênio DNPM-CPRM, 1977, 639p. 


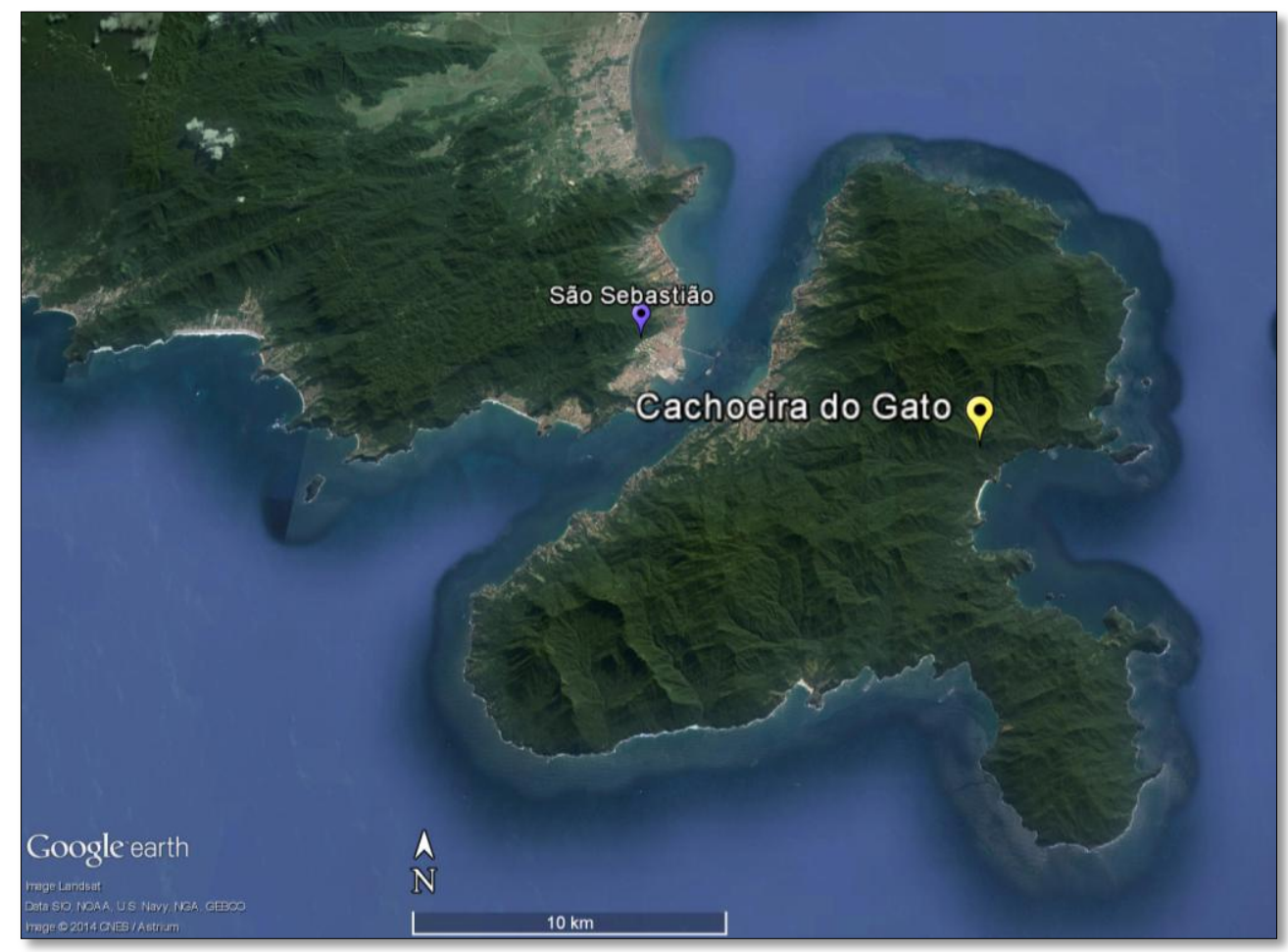

Figura 4.3.1 - Localização da Cachoeira do Gato na llha de São Sebastião.

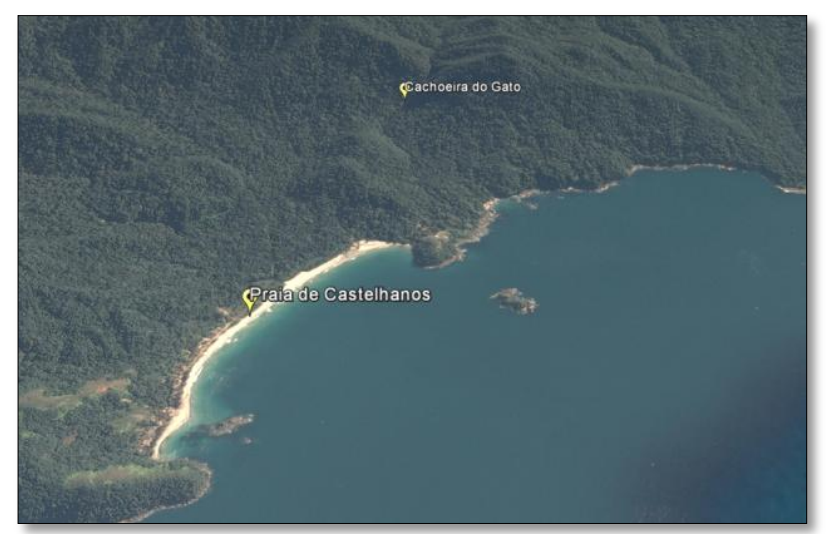

Figura 4.3.2 - A localização da Cachoeira do Gato em relação à Praia de Castelhanos. 


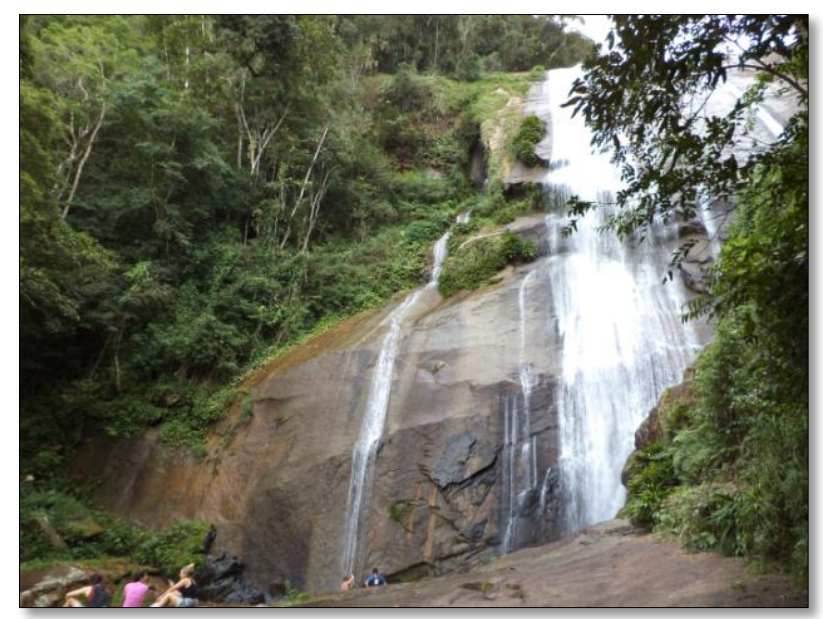

Figura 4.3.3 - O paredão da cachoeira se eleva por cerca de $50 \mathrm{~m}$ e a queda da água forma uma piscina natural que é atrativo turístico do local.

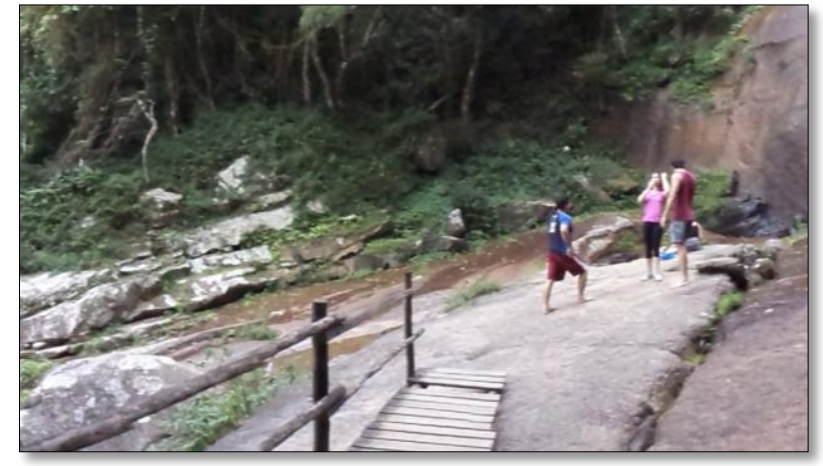

Figura 4.3.4a - A instalação de uma passarela pelo Parque Estadual facilita o acesso à água e a segurança dos turistas.

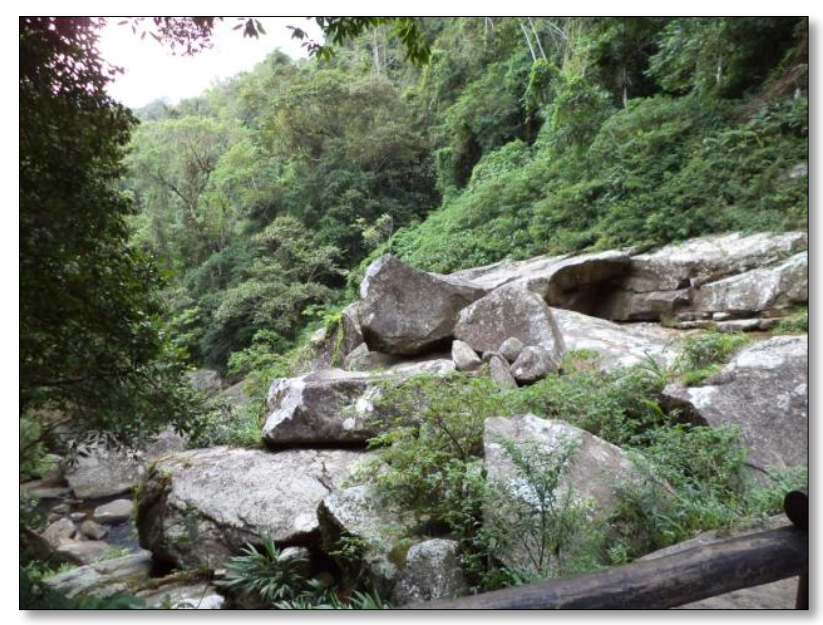

Figura 4.3.4b - A declividade do terreno aumenta e a água segue seu caminho em direção ao oceano por entre blocos de grandes dimensões. 


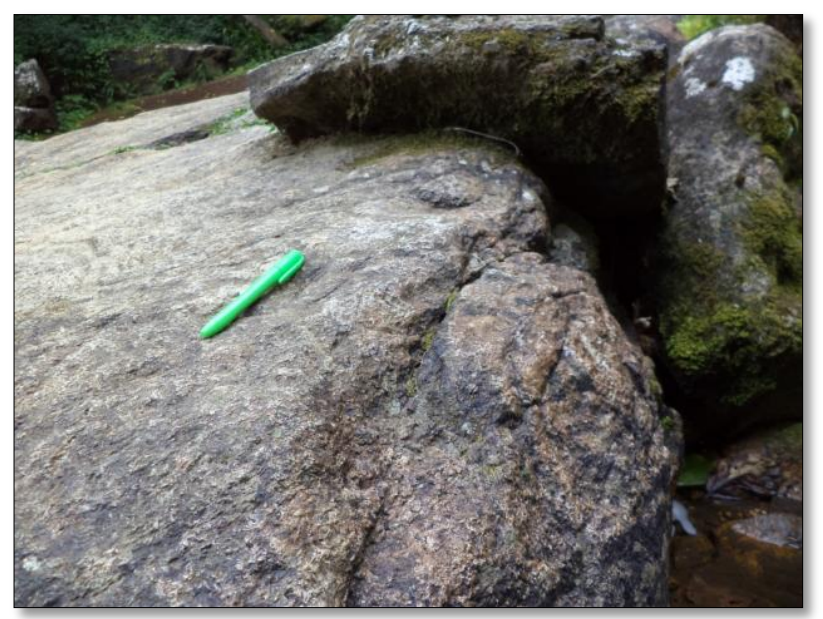

Figura 4.3.5 - A rocha aflorada está degradada, devido à exposição contínua, ou já coberta por musgos que aceleram sua degradação por intemperismo biológico.

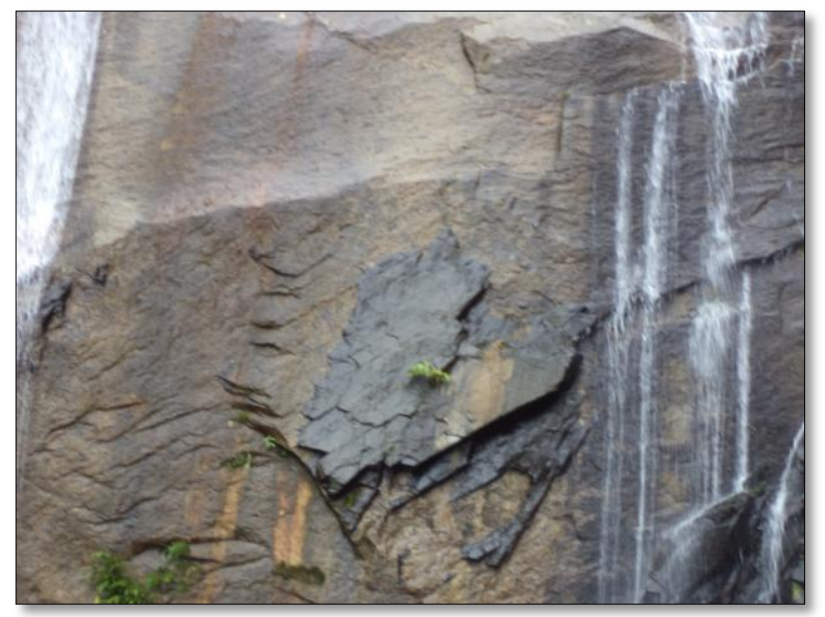

Figura 4.3.6a - Remanescente de dique no paredão. O formato empresta o nome à cachoeira, já que os moradores locais enxergam nele as feições de um gato.

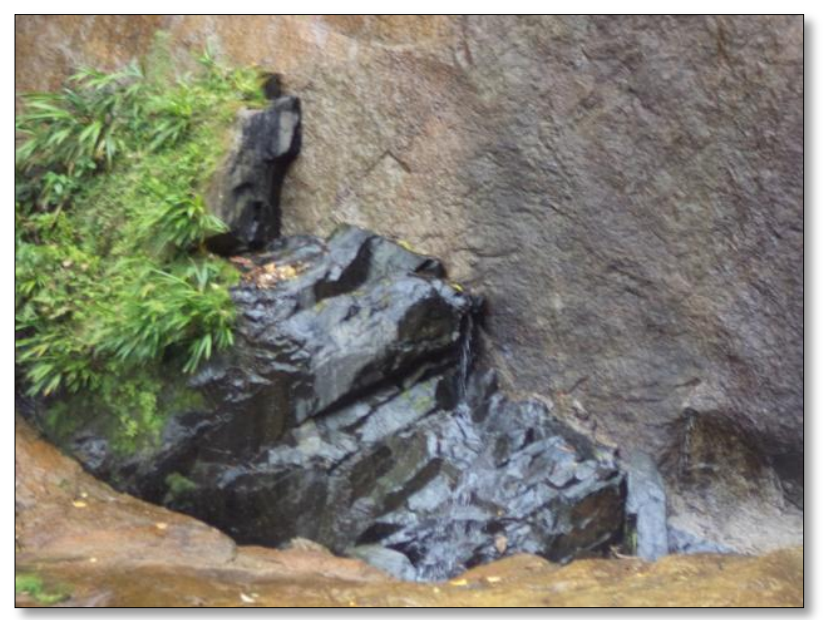

Figura 4.3.6b - Outro remanescente de dique, desta vez no canto inferior esquerdo do paredão. Infere-se que os dois "restos" tenham sido parte constituinte do mesmo corpo intrusivo. 


\subsection{GEOSSÍTIO PRAIA DA FIGUEIRA - AS AREIAS VERMELHAS}

Localização (UTM): 471707 / 7358582 (ponto médio da praia)

Tipo: Pontual

Acesso: De barco ou através de uma trilha de cerca de $2 \mathrm{~h}$ de duração, que sai da Praia de Castelhanos.

Dimensão: a praia tem aproximadamente $270 \mathrm{~m}$ de extensão

Unidade dentro do mapa da CPRM (2006): NPccgm - unidade granito gnáissica migmatítica: hornblenda-biotita gnaisse granitóide porfiróide e augen gnaisse, de idade entre 647 e578 Ma (U - Pb).

Justificativa do valor científico: apresenta areias de cor intensamente avermelhada, devido à grande concentração de granada (cerca de 90\% - ARAMAQUI, 2013).

Elementos principais de interesse:

A Praia está localizada em uma pequena enseada dentro da Baía dos Castelhanos e é atrativo turístico por suas águas calmas e ambiente propício para a pesca e mergulho. Não há comércio, somente uma casa colonial e uma outra, de pescadores. A praia dista cerca de $1700 \mathrm{~m}$ (em linha reta) da Praia Vermelha (Fig.4.4.2) que, apesar do nome, apresenta aspecto e coloração da areia menos avermelhadas que a Praia da Figueira. É dessa observação que decorre a escolha deste geossítio, em detrimento da Praia Vermelha (Fig. 4.4.3a/b)

Trata-se de uma praia intermediária reflexiva (estágio 4 ou 5 da escola australiana), com cúspides pronunciadas de cerca de $10 \mathrm{~m}$. A parte norte apresenta largura menor que a parte sul (14 m e 18,5 m respectivamente), do cristalino à zona de espraiamento. Há berma pronunciada na parte central, com falésia de 0,8m especialmente na parte norte (ARAMAQUI, 2013).

A areia da parte norte apresenta maior concentração de minerais pesados, destacando-se a granada, e, na parte sul, é mais grossa e cascalhosa. Por isso, pode-se concluir que, ao menos no momento da observação, (5/7/2013, às 10:05 da 
manhã), a parte norte era mais erosiva que a parte sul. (GIANNINI, 2014 informação verbal ${ }^{1}$ ), (Fig.4.4.4a/b e Gráfico 4.4.4).

Toda a praia é cercada por uma rocha granitoide com cristais centimétricos de feldspato cinza e subcentimétricos de granada. Uma amostra desta rocha, descrita por Pileggi ${ }^{2}$ (2013) revela um clorita-biotita-granada monzogranito, com textura inequigranular seriada, composta por biotita, granada, clorita (pós-magmática) e minerais acessórios (muscovita, apatita e opacos). A textura de mirmequita é característica em algumas porções da rocha, que apresenta ainda feldspato verde.

Outros tipos de interesse: Turístico (com atividades de pesca e mergulho).

Uso potencial: Científico e didático (nível universitário e ensino médio).

Vulnerabilidade: Natural baixa. Antrópica baixa.

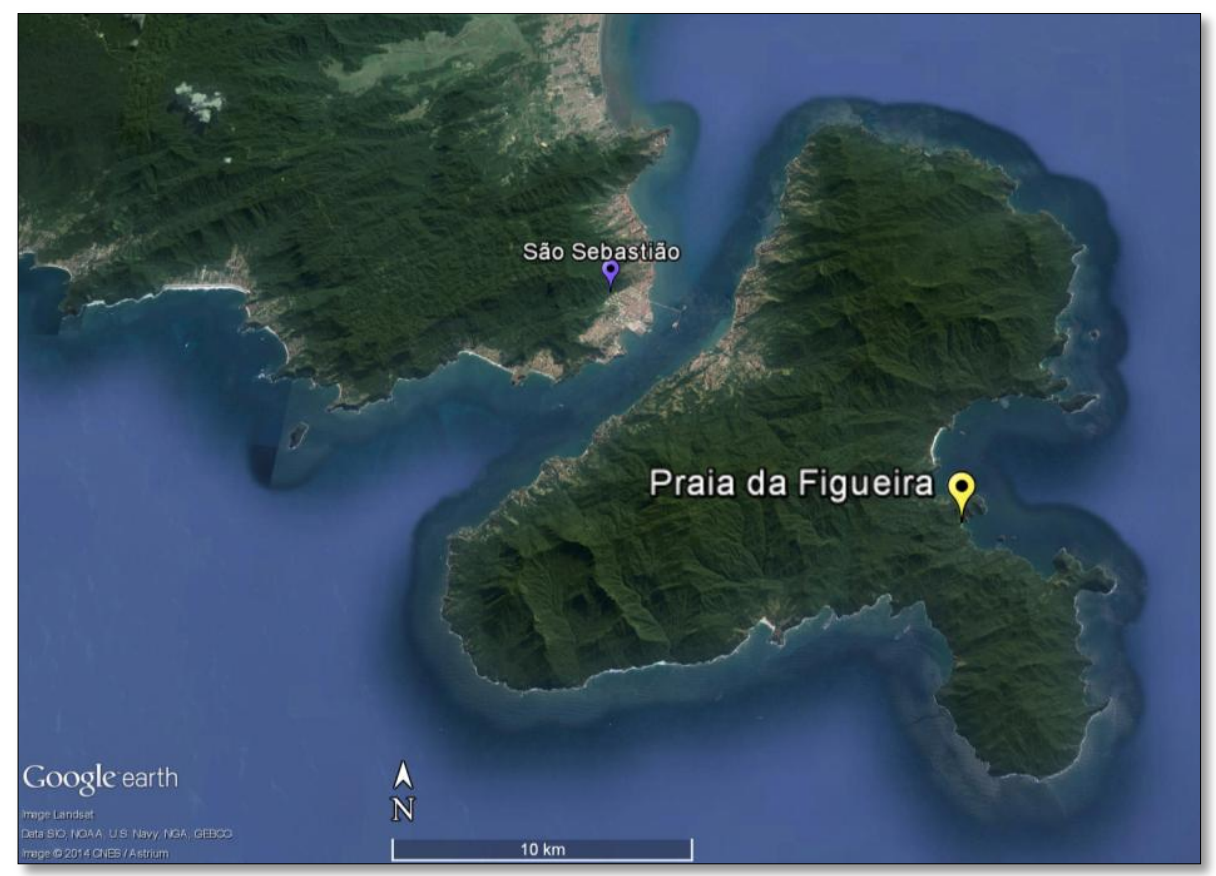

Figura 4.4.1 - Localização do ponto médio do geossítio Praia da Figueira, na llha de São Sebastião

${ }^{1}$ Informação fornecida pelo Prof. Dr. Paulo C.F. Giannini em fevereiro de 2014.
2 PILEGGI, F. Banco de Dados Petrográficos dos Geossítios do Litoral Norte do Estado de São Paulo. Iniciação Científica - em andamento. 


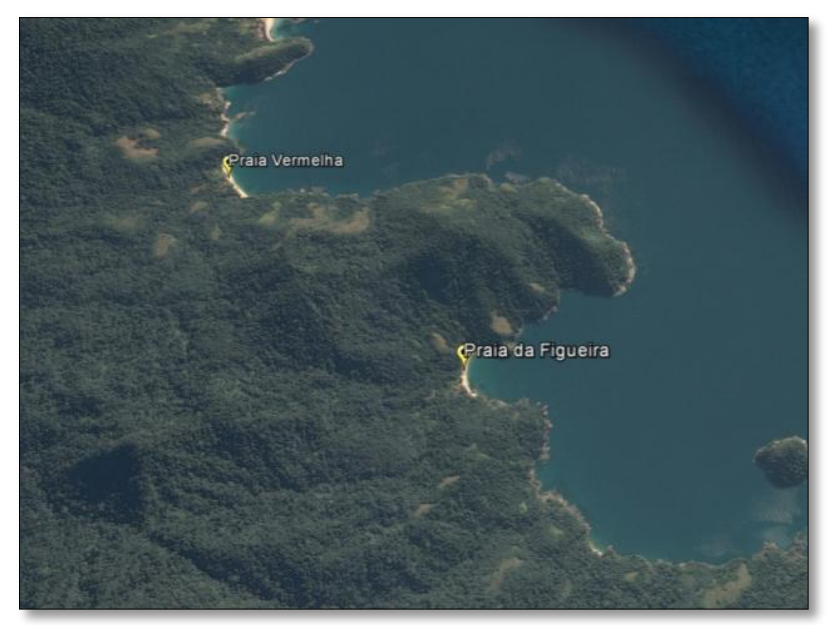

Figura 4.4.2 - As Praias Vermelha e da Figueira em relação uma à outra. A distância em linha reta entre as duas é de aproximadamente $1.700 \mathrm{~m}$.

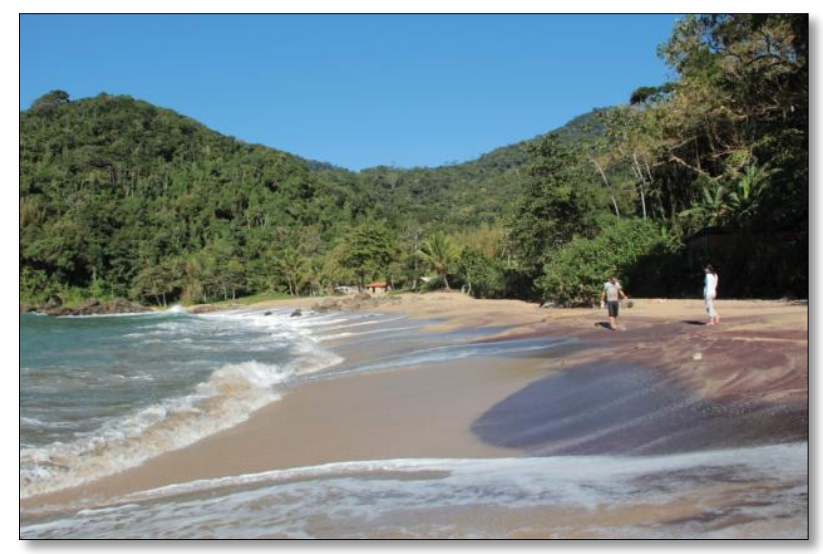

Figura 4.4.3a - A Praia da Figueira, uma faixa de cerca de 300m de areia com porções avermelhadas devido à grande concentração de granada (Foto: Christine Bourotte).

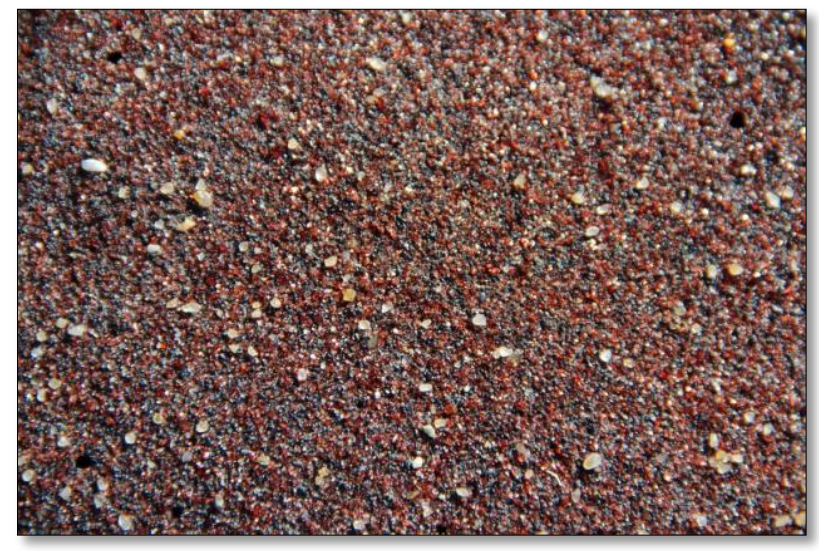

Figura 4.4.3b - Areia da Praia da Figueira, cuja concentração de granada chega a cerca de 90\% (Foto: Christine Bourotte). 


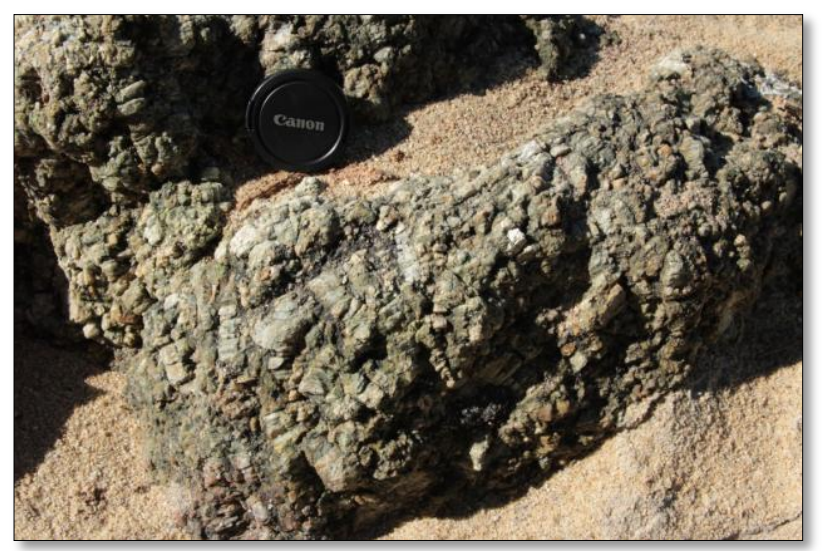

Figura 4.4.4a - Os cristais centimétricos de feldspatos no clorita-biotita-granada monzogranito que cerca a praia toda (Foto: Christine Bourotte).

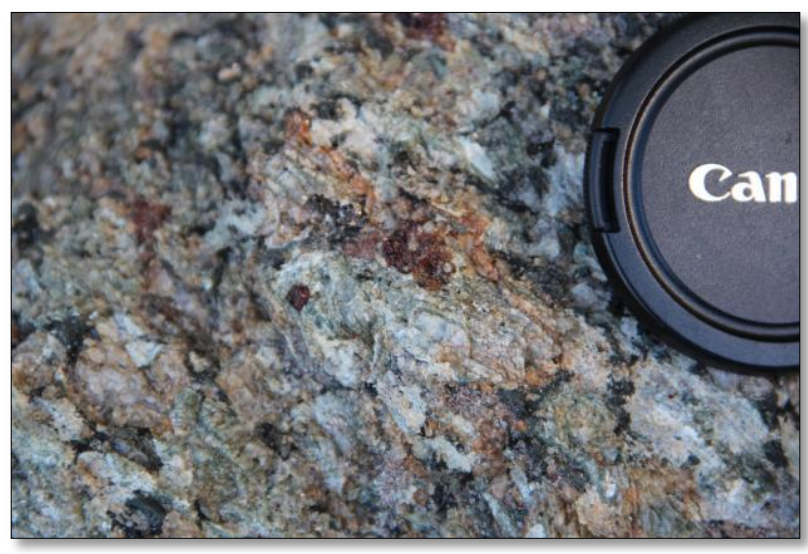

Figura 4.4.4 b - Detalhe do granitoide que envolve toda a praia da Figueira, mostrando os cristais subcentimétricos de granada (Foto: Christine Bourotte).

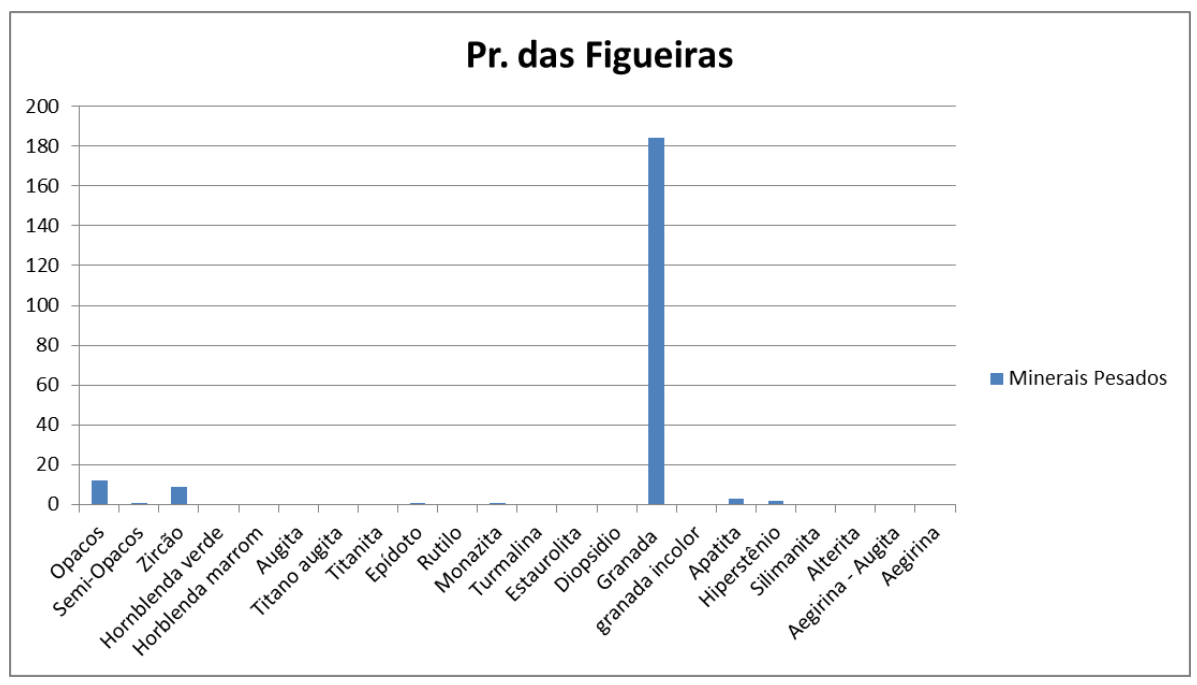

Gráfico 4.4.4 - Composição da assembleia de minerais pesados na areia da Praia da Figueira (contagem em lâmina), com predominância de granada (ARAMAQUI, 2013). 


\subsection{GEOSSÍTIO PRAIA DE ENCHOVAS - AS PEDRAS ROLADAS}

Localização (UTM): 467056 / 7355419 (ponto médio da praia - Fig.4.5.1)

Tipo: Perfil

Acesso: De barco ou através de uma trilha de cerca de 50 min de duração, que inicia na Praia do Bonete. A trilha do Bonete é uma trilha longa (12 km), de 4 a 6 horas de duração e nível alto, que sai da Ponta da Sepituba e só pode ser percorrida a pé.

Dimensão: a praia tem aproximadamente $350 \mathrm{~m}$ de extensão.

Unidade dentro do mapa da CPRM (2006): NPccgm - unidade granito gnáissica migmatítica: hornblenda-biotita gnaisse granitóide porfiróide e augen gnaisse, de idade entre 647 e578 Ma (U - Pb).

Justificativa do valor científico: apresenta seixos rolados de tamanhos variados, representativos de vários litotipos da ilha; é um exemplo didático ilustrativo de zona de tormenta; é um local possível de acessar e ilustrar didaticamente o contato entre gabro e granito porfirítico no sul da ilha, esclarecendo relações estruturais entre os litotipos presentes na ilha.

Elementos principais de interesse:

A Praia de Enchovas é a praia mais próxima da Praia do Bonete (aproximadamente $2200 \mathrm{~m}$ de distância em linha reta - Fig.4.5.2). O acesso se dá através de trilha de dificuldade média a fácil a partir do Bonete e que leva cerca de 50 minutos para ser percorrida (Fig.4.5.3).

Enchovas é uma praia reflexiva, com face praial íngreme, berma de $12 \mathrm{~cm}$ de largura e mergulho suave para o mar. No interior da berma pode-se apontar zona de tormenta declivosa e extensa (cerca de 6 graus de declive para o mar e $11 \mathrm{~m}$ de largura). Na porção interna dessa storm beach, onde o terreno sub-horizontal está coberto por vegetação arbustiva, a areia é rica em minerais pesados na metade inferior e por cascalho na metade superior. Esta porção interna da zona de tormenta 
apresenta segregação de minerais de diferentes cores, acompanhando a lineação de corrente (GIANNINI, 2014 - informação pessoal ${ }^{1}$ ).

Entre os minerais que constituem a assembleia de pesados, $55 \%$ de opacos, $2 \%$ de semiopacos, $5 \%$ de hornblenda marrom e $4,5 \%$ de hornblenda verde fazem com que a areia tenha porções de aspecto bem escuro (Aramaqui, 2013 - Fig.4.5.4).

A zona de tormenta está coberta de seixos bastante trabalhados, (alguns chegam a estar ovalados) que variam de tamanho, de 10 centímetros de comprimento em seu eixo maior até blocos mais pesados de 30 ou $40 \mathrm{~cm}$ (Fig.4.5.5). Entre os tipos litológicos observadas nestes blocos rolados, provavelmente transportados por agentes fluviais e retrabalhados pela energia das ondas, puderam ser aferidos: basalto com fenocristais de plagioclásio, granito deformado, granito com veios de quartzo, granito com fluxo magmático (refletido nos fenocristais de feldspato orientados), granito com feldspatos esverdeados e gabro (Fig. 4.5.6a/b).

Na ponta leste da praia, observa-se um promontório de dimensões métricas, (cujo tipo litológico não foi possível precisar, pois a rocha se encontra alterada e não conseguimos acessá-la devido à maré), que adentra o mar. Por conta deste posicionamento dos matacões, entende-se que são parte de um mesmo bloco muito maior, que foi intemperizado e "esculpido" pelas ondas. Sua disposição, com alinhamento na direção NE/SW está relacionada à fase de amalgamação do Gondwana e ao trend regional do Orógeno Ribeira (HEILBRON et al, 2004).

Além deste alinhamento se encontra o costão rochoso, com acesso restrito através de uma trilha por dentro da vegetação, utilizada pela família que reside no local. Neste ponto observa-se o contato de gabro com o granito porfirítico (Fig. 4.5.7). Não há trabalhos acadêmicos sobre estes tipos litológicos ou as relações entre eles neste ponto da ilha, tampouco se encontram figurados em mapas geológicos, sendo tema interessante para investigação futura.

Uso potencial: Científico e didático (nível universitário).

Vulnerabilidade: Natural baixa. Antrópica baixíssima.

${ }^{1}$ Giannini, P.C.F. Notas de campo sobre a Praia de Enchovas. Mensagem recebida por rprochoroff@gmail.com em 1 mar. 2014. 


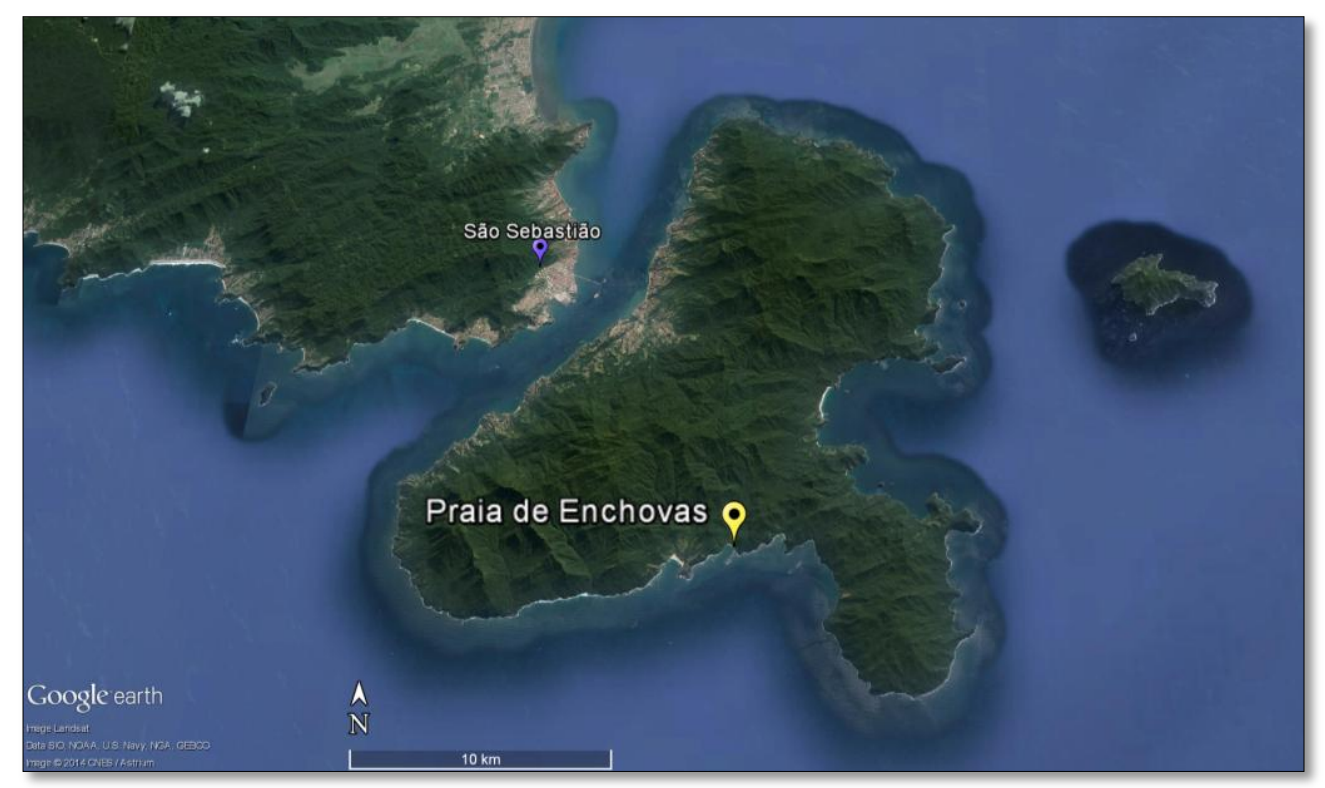

Figura 4.5.1 - A localização do geossítio Praia de Enchovas na ilha de São Sebastião.

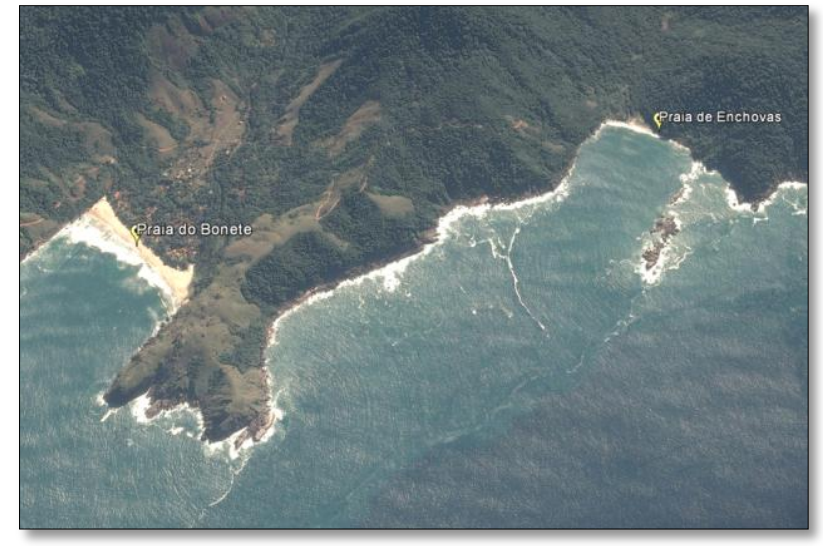

Figura 4.5.2 - A Praia de Enchovas dista cerca de 2200m em linha reta da Praia do Bonete. Por esta imagem aérea pode-se ver o alinhamento de blocos na direção NE/SW que delimita um dos lados da praia. 


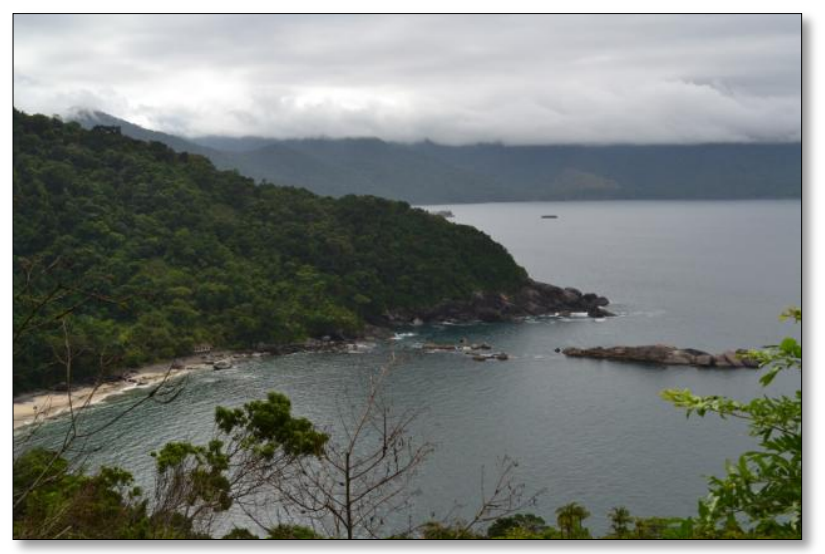

Figura 4.5.3 - Praia de Enchovas vista em ponto alto da trilha de acesso, que sai da Praia do Bonete.

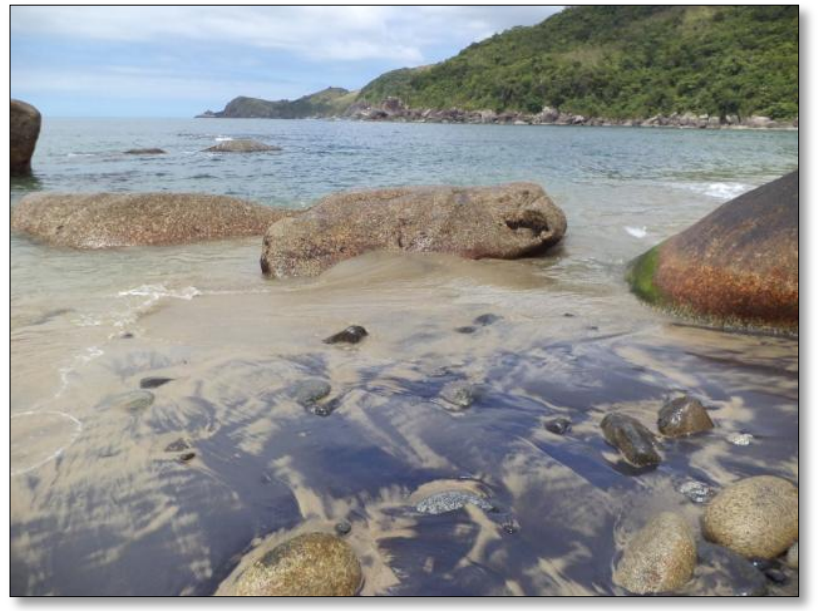

Figura 4.5.4 - A alta concentração de minerais pesados opacos e semi opacos (57\%) conjugada a minerais transparentes de cores mais escuras, como a hornblenda marrom e a hornblenda verde, faz com que a areia tenha grandes porções com aparência bastante escura.

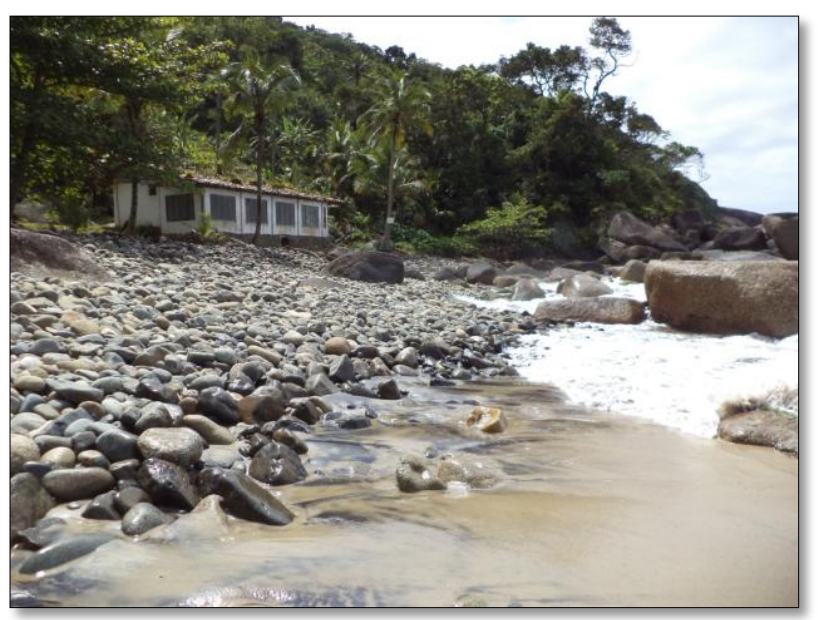

Figura 4.5.5 - Zona de tormenta da Praia de Enchovas, coberta de seixos e blocos de tamanhos e tipos litológicos diversos. 


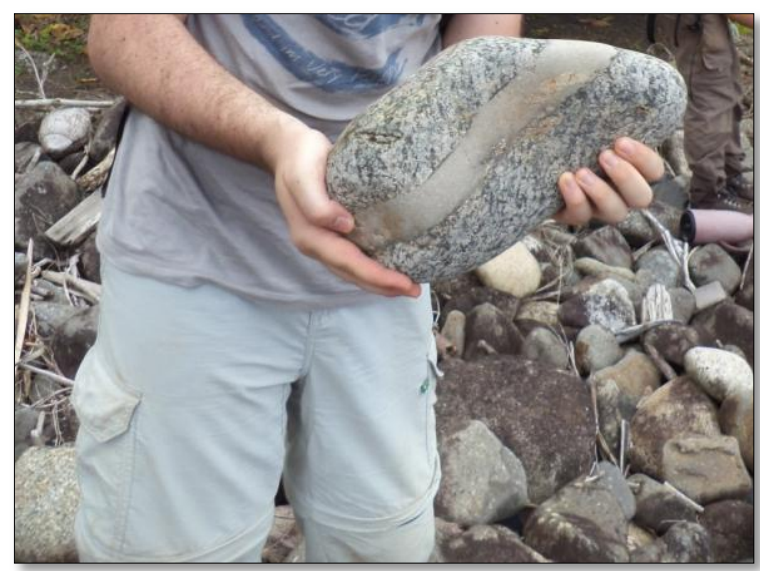

Figura 4.5.6a - Bloco de granito profirítico cortado por um veio de quartzo, de cerca de $35 \mathrm{~cm}$ em seu eixo longitudinal e arredondado pelo retrabalhamento das ondas na zona de tormenta.

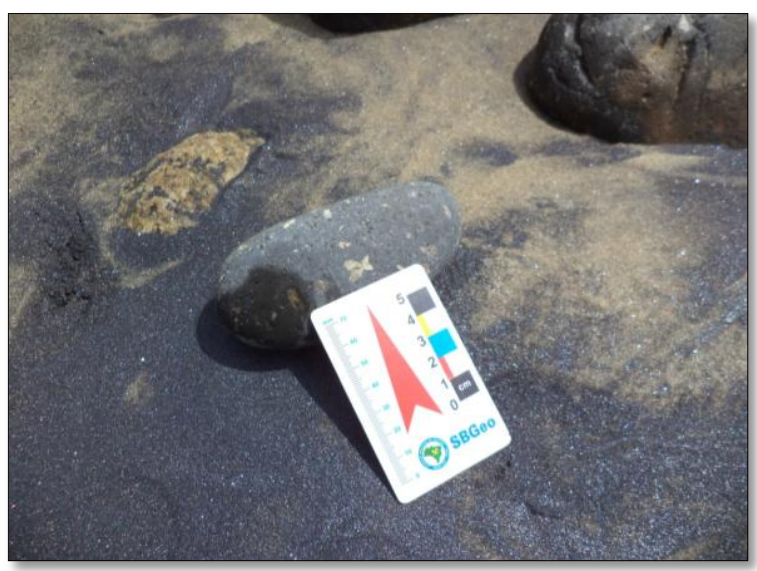

Figura 4.5.6b - Seixo de basalto bem retrabalhado, com $5 \mathrm{~cm} \times 11 \mathrm{~cm}$ de dimensão, apresentando cristais sub-centimétricos de plagioclásio. Indicado pela seta vermelha da escala, um cristal geminado.

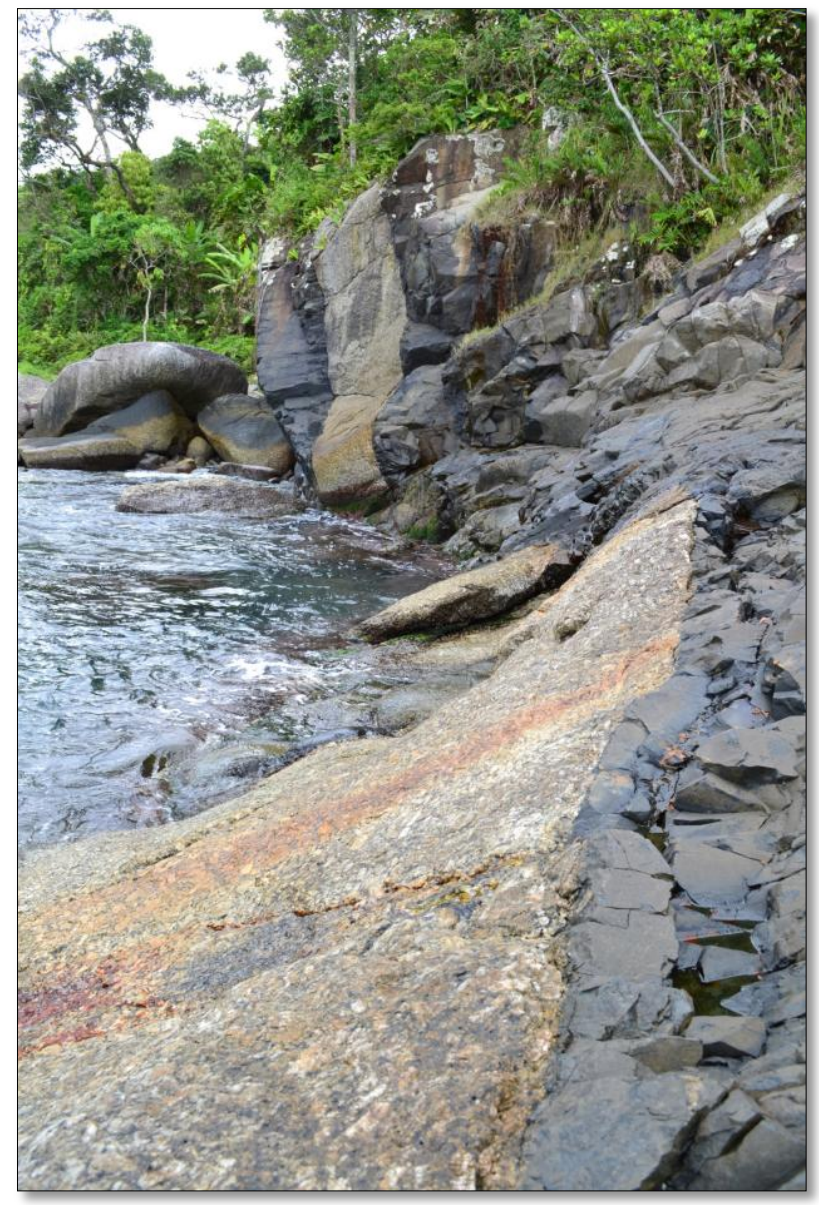

Figura 4.5.7 - Contato entre granito porfirítico e gabro, no ponto além do alinhamento de rochas que marca o final leste da Praia de Enchovas, já no início do costão rochoso. (Foto: Erick Mota) 


\subsection{GEOSSÍTIO BURACO DO CAÇÃO}

Localização (UTM): 0457950 / 7352560 (Fig. 4.6.1)

Tipo: Pontual

Acesso: por trilha a pé, local, que inicia no primeiro terço da Trilha do Bonete, logo após o Morro do Cação. O acesso para esta trilha menor é indicado por placas. As coordenadas da entrada desta trilha são: 0457804 / 7352731.

Dimensão: o paredão tem aproximadamente $60 \mathrm{~m}$ de altura. A área onde é possível se movimentar, próximo à beirada, é de cerca de $60 \mathrm{~m}^{2}$.

Unidade dentro do mapa da CPRM (2006): K2入se - Complexo plutônico alcalino São Sebastião: nordmarkito; nas bordas dos stocks, sienito, localmente sienito nefelínico. Idade: $81 \mathrm{Ma} \mathrm{Rb}-\mathrm{Sr}$.

Justificativa do valor científico: afloramento de dimensões de centenas de metros quadrados de rocha alcalina, com indicativo de existência prévia de um dique que intrudiu o stock na direção NE/SO e que foi posteriormente consumido por erosão diferencial. Este afloramento testemunha os processos de tectônica rúptil que ocorreram após a fragmentação do Gondwana.

Elementos principais de interesse: O local conhecido como Buraco do Cação está inserido no maciço alcalino São Sebastião, no sul da ilha. O local, um dos mais importantes atrativos turísticos da região, é um boqueirão de cerca de $60 \mathrm{~m}$ de altura (Fig. 4.6.2) e o acesso a ele pode ser pelo topo, através de uma trilha secundária que sai da Trilha do Bonete, logo após o Morro do Cação, ou de barco pelo mar.

De cima do paredão os turistas costumam observar o mar, onde não é raro avistar golfinhos e tartarugas marinhas (alguns moradores locais e guias turísticos reportaram baleias em poucas ocasiões). As águas que atingem o pé do paredão são bastante claras e frequentemente espumantes e por isso, bastante oxigenadas (Fig. 4.6.3).

Uma possível explicação para essa abertura na parede rochosa advém de sua direção, que é NE/SW e paralela aos principais diques da ilha (ALMEIDA, 1986; 
BELLIENI et al, 1990; IPT, 1981; RICCOMINI, 1995;- Fig 4.6.4a): analogamente ao resto do território de llhabela, esse local pode ter sido intrudido por um dique, que mais tarde sofreu erosão diferencial. Corrobora essa hipótese a observação de campo em outros locais da ilha, como, por exemplo, a Praia da Fome, no extremo norte, onde o boqueirão, também de direção NE/SO, ainda exibe remanescentes do dique que o formou, ao intrudir o maciço Serraria (Fig. 4.6.4b), aproveitando as fraturas da rocha para ser colocar.

Caso isso tenha realmente ocorrido no Buraco do Cação, o dique deve ter sido posteriormente intemperizado, sobrando somente a abertura entre as paredes, por onde o mar adentra. Suas paredes em ambos os lados apresentam um sistema de fraturas de direção preferencial NE, que condizem com a atitude dos sistemas preponderantes da ilha. A abertura entre as paredes é mais larga no contato com o mar, cujas ondas, principalmente vindas do sul, podem ter acelerado o intemperismo do dique hipotético, já que as ondas preferenciais que atingem Ilhabela são as de $S$ e E (LOURENÇO, 2012; PIANCA et al, 2010; - Fig. 4.6 .5 a/b).

A observação ao redor do pequeno promontório do topo revela blocos soltos, menores e de arestas mais arredondadas, ladeando blocos maiores e de formas e arestas mais preservadas. Isso sugere que a rocha sofreu fraturas em direções preferencialmente ortogonais, por onde a água percolou e outros agentes de intemperismo agiram, moldando os blocos que depois se separaram da rocha principal (Fig. 4.6.6a/b).

Sabe-se que o local está no maciço alcalino São Sebastião, mas não há trabalhos identificando qual o tipo litológico desta porção do stock. A observação de campo de matacões ao longo do caminho para o Buraco do Cação e a existência de blocos que foram cortados ilegalmente para fins de construção civil (que é proibida dentro dos limites do parque, pela regulamentação do PElb) sugerem uma rocha sienítica.

No tocante ao uso didático deste geossítio, supõe-se que seja possível explorar, além do tectonismo já mencionado, um pouco do intemperismo de rochas alcalinas. Para as seguintes inferências, meramente especulativas, utilizaram-se trabalhos que discutiram a questão, sem, no entanto ser possível afirmar com certeza absoluta qual tipo de rocha alcalina é a que encontramos no Buraco do Cação. 
Sabe-se que tipos litológicos distintos podem apresentar padrões de intemperismo diferentes, devido à textura e composição mineralógica. No intemperismo de rochas sieníticas, a nefelina é lixiviada, deixando espaços vazios que são conhecidos como caneluras. A decomposição da nefelina e dos feldspatos alcalinos de rochas traquíticas, sieníticas e nefelina sieníticas libera sílica que, fazendo a coesão dos materiais intempéricos, impermeabiliza a superfície da rocha (MOTOKI et al, 2007). Na verdade, o intemperismo ocorre ao longo das fraturas, mas não segue a mesma taxa das rochas graníticas (MOTOKI et al., 2008). Por isso, a subsuperfície continua pouco alterada, mesmo que seja intenso o intemperismo na superfície de rochas como sienito e nefelina sienito (Fig. 4.6.7)

Petrakis et al. (2010) fazem algumas inferências que talvez possam ser aplicadas a este local. Para eles, é interessante o uso de álcali sienito para a fabricação de concreto, já que este não sofre as reações de álcali agregados, tão danosas para a construção civil. O álcali sienito ocorre em fase final de separação continental, como nas llhas de São Sebastião, Vitória e Búzios (constituintes do arquipélago de São Sebastião), bem como em retroarco de zona de colisão continental. $\mathrm{Na}$ ocorrência do Maciço Tunas (PR), o álcali sienito é comercializado como rocha ornamental, o Granito Verde Tunas. A rocha fresca do Buraco do Cação é tão esverdeada, que 1994 o DNPM expediu um laudo afirmando que a rocha era um charnockito (nformação verbal ${ }^{1}$ ).

O local carece de estudos geoquímicos e mineralógicos para a caracterização do tipo litológico. Porém, podemos inferir que esta não é exatamente a mesma rocha que aflora a noroeste da ilha, pois os padrões de intemperismo são totalmente distintos. Na Praia do Jabaquara, na Pedra do Sino e no bairro da Siriúba, (contíguo à praia do Garapocaia), a nefelina lixiviada forma as caneluras pronunciadas (Fig 4.6.8). Ao contrário, a rocha do Buraco do Cação pode ser um álcali sienito com case hardening: em condições ideais, (alta temperatura, alta umidade e clima tropical) o manto de intemperismo composto de materiais argilosos originados do feldspato alcalino cobre a rocha e impossibilita a percolação de água por ela, como pôde ser visto na Fig. 4.6.7.

${ }^{1}$ Informação fornecida pela Sra.Maria Iranice Troncha, antiga dona do local, que apresentou o referido laudo, em 4 nov 2012. 
Em vista de tudo o que foi exposto, este local fornece um excelente e didático exemplo de como o intemperismo age nas rochas alcalinas, com os blocos do topo do Buraco do Cação, e de como se comporta a erosão diferencial (neste caso, do dique hipotético).

Outros tipos de interesse: Turístico.

Uso potencial: Científico e didático (nível universitário).

Vulnerabilidade: Natural baixíssima. Antrópica baixíssima.

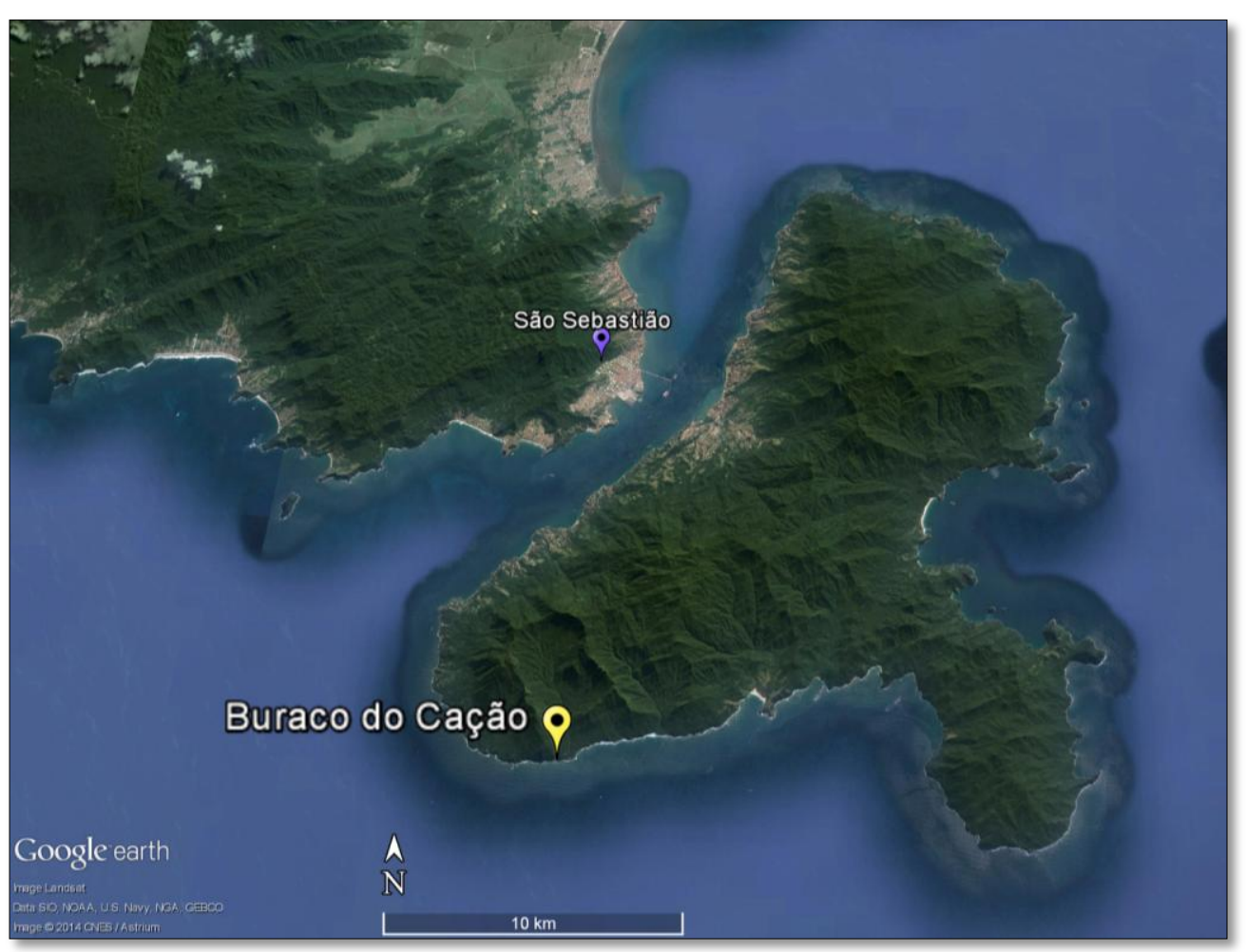

Figura 4.6.1 - Localização do geossítio Buraco do Cação na llha de São Sebastião. 


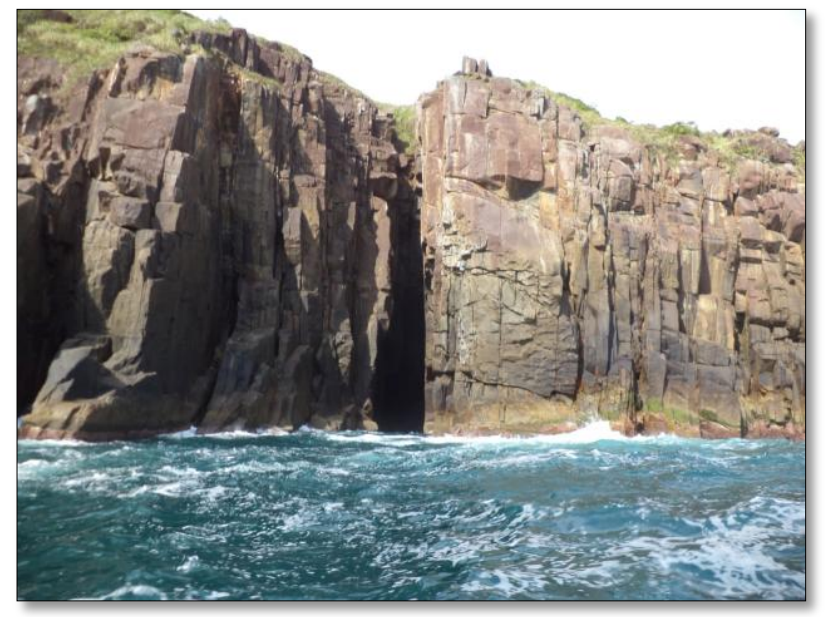

Figura 4.6.2. - O Buraco do Cação visto do mar. A altura deste paredão é de aproximadamente $60 \mathrm{~m}$ e a separação entre as duas partes, no ponto mais alto, é de cerca de $5 \mathrm{~m}$.

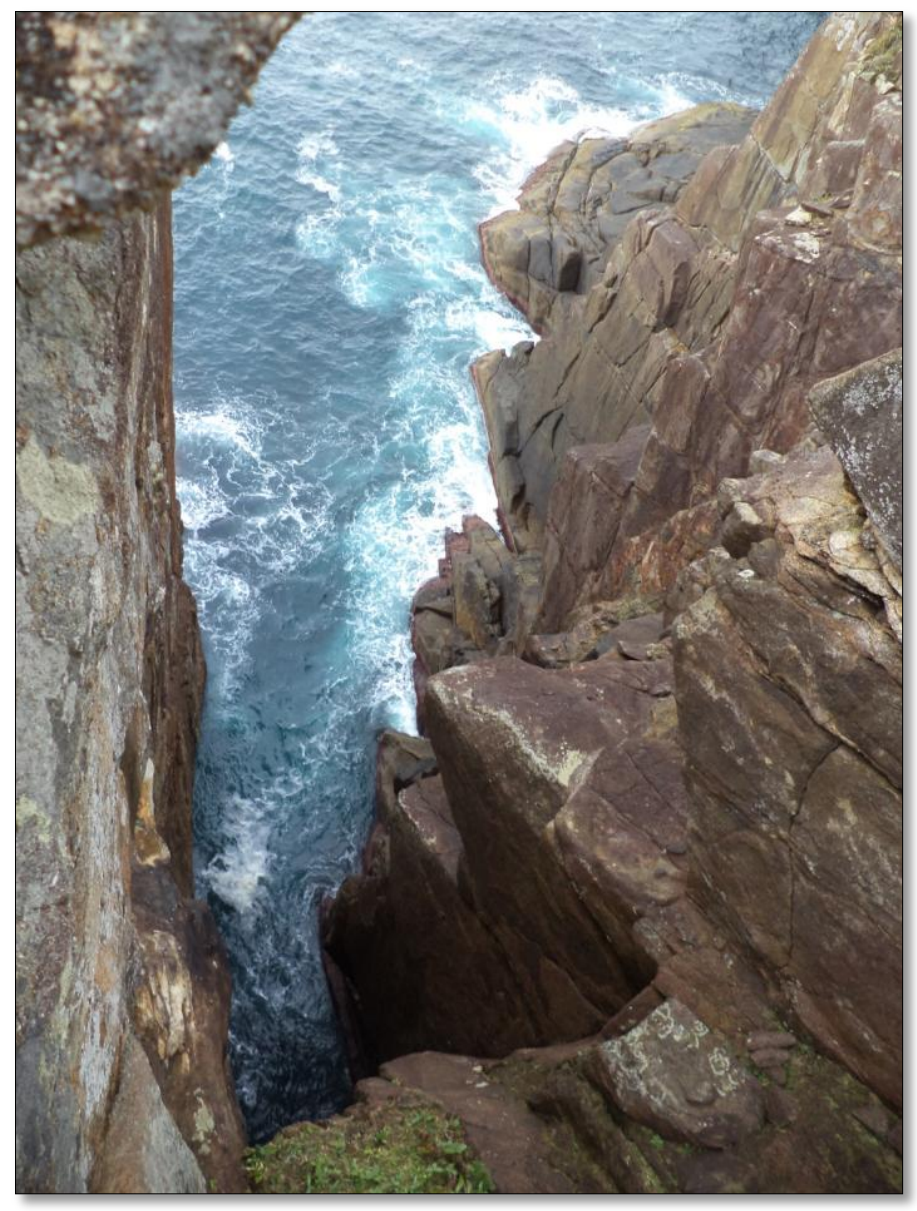

Figura 4.6.3 - A água do mar ficam azuis e claras ao pé do paredão, oxigenadas pelo movimento constante das ondas. 


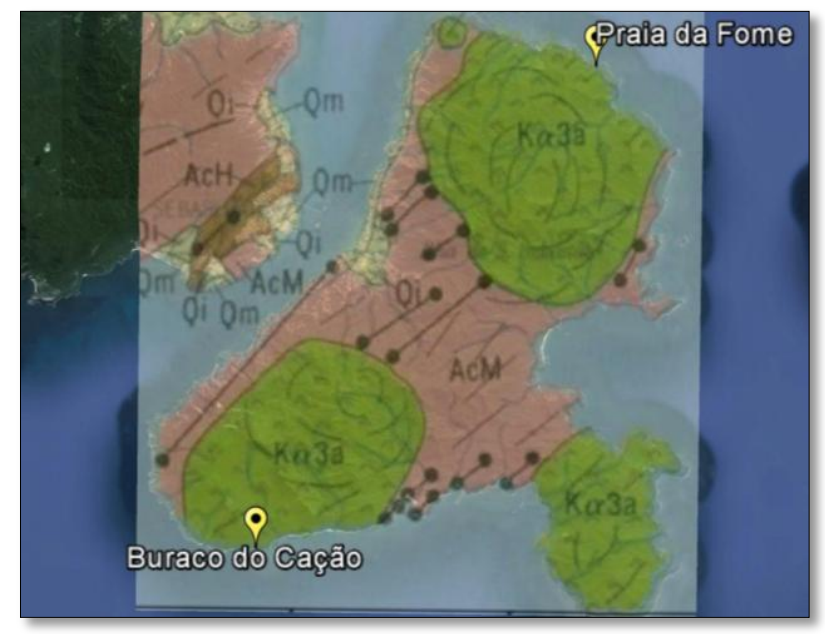

Figura 4.6.4a - Sobreposição do mapa geológico (IPT, 1981) sobre a imagem de satélite da llha de São Sebastião, com a localização da Praia da Fome e do Buraco do Cação. A observação do remanescente de dique no boqueirão da Praia da Fome, de orientação NE/SO, faz supor que o Buraco do Cação tenha sido formado pelo mesmo processo.

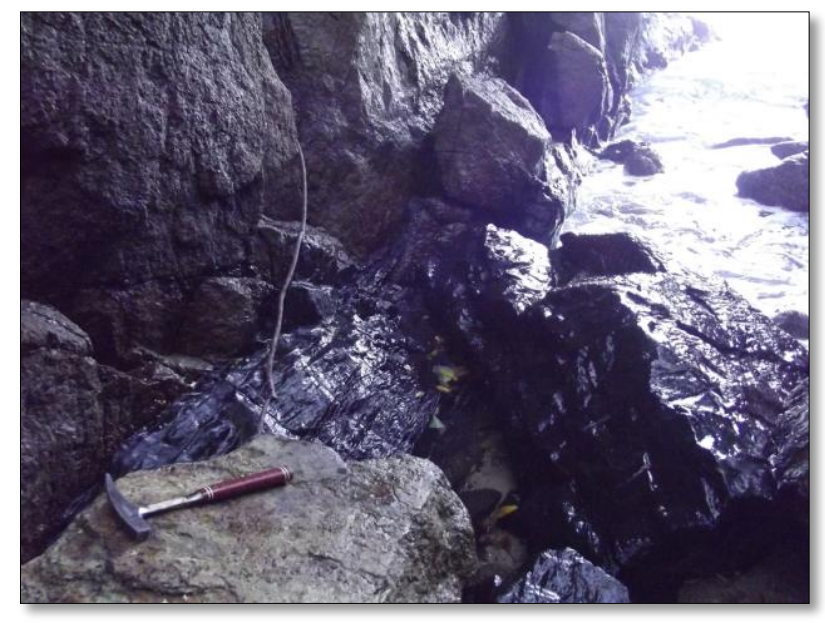

Figura 4.6.4b - O boqueirão da Praia da Fome com o dique remanescente, ambos orientados na direção NE/SO, como a maioria dos diques principais da ilha. 


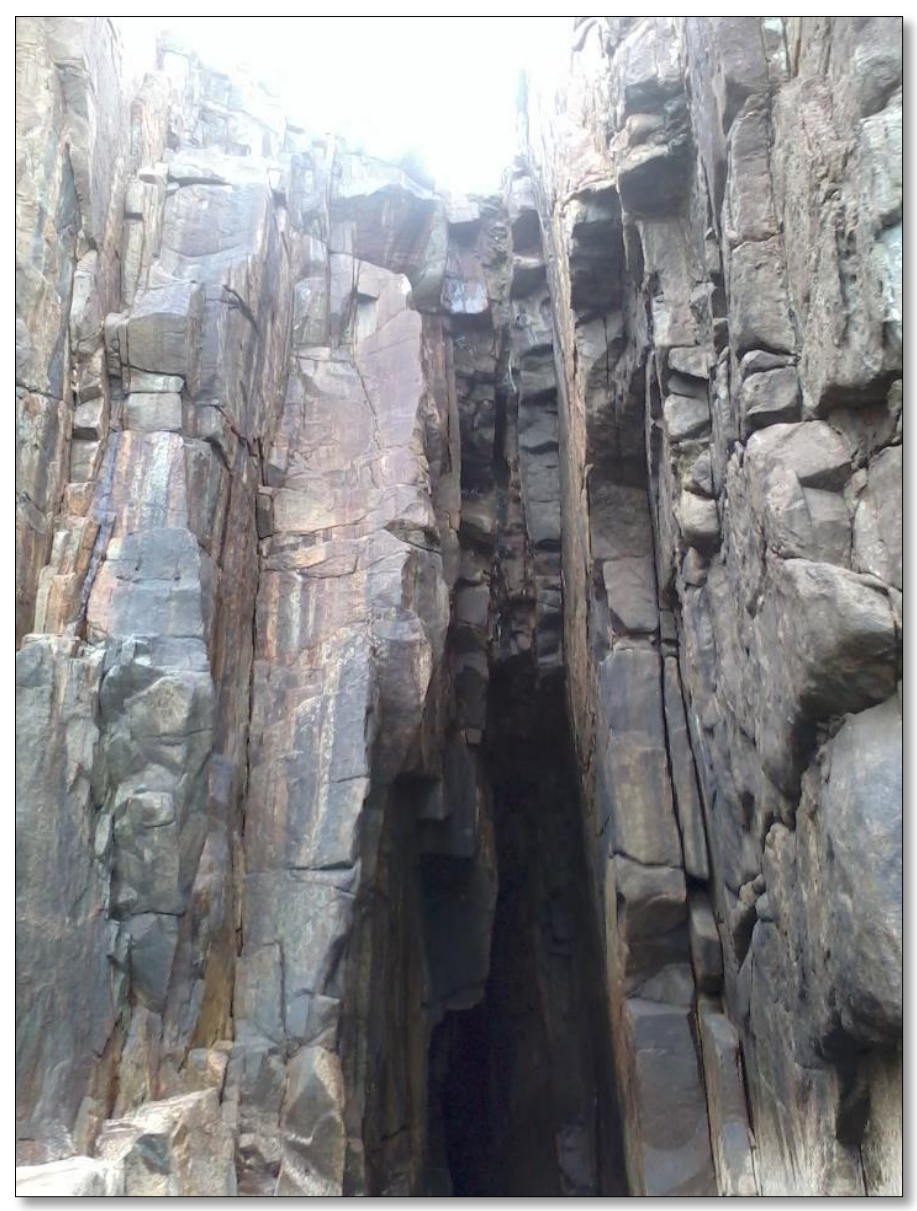

Figura 4.6.5a - Vista da parte superior do Buraco do Cação. A direção preferencial de fraturas, NE/SO, condiz com a dos outros sistemas de diques e fraturas da ilha. (Foto: Fernanda Palhares)

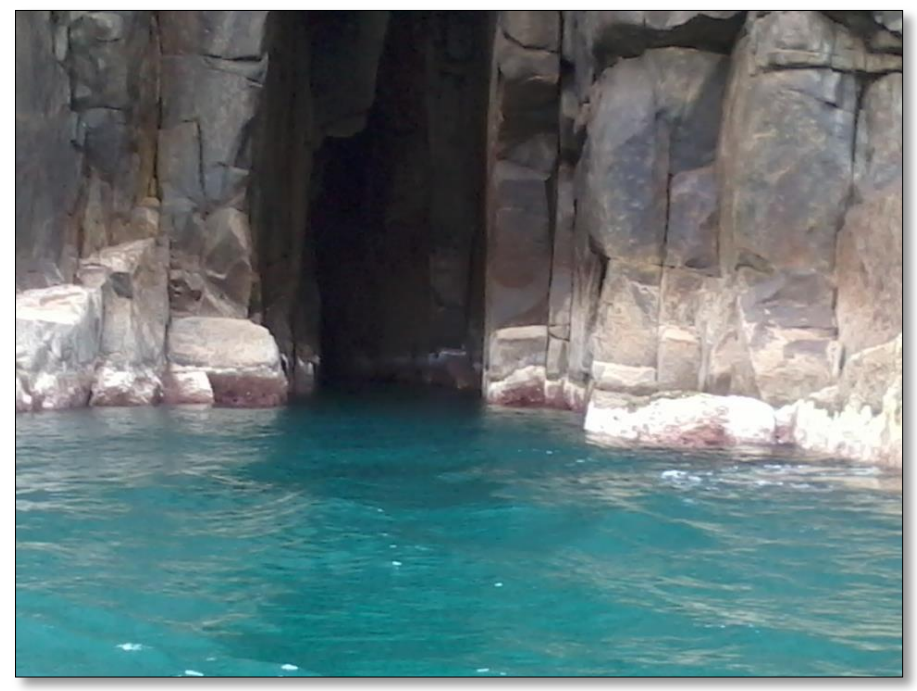

Figura 4.6.5b - O Buraco do Cação, em sua interface com a água, é mais largo. As ondas que atingem a ilha são preferencialmente de sul e leste e este pode ser um dos motivos pelo qual o dique hipotético foi totalmente cominuído, sem sobrar vestígios. (Foto: Fernanda Palhares) 


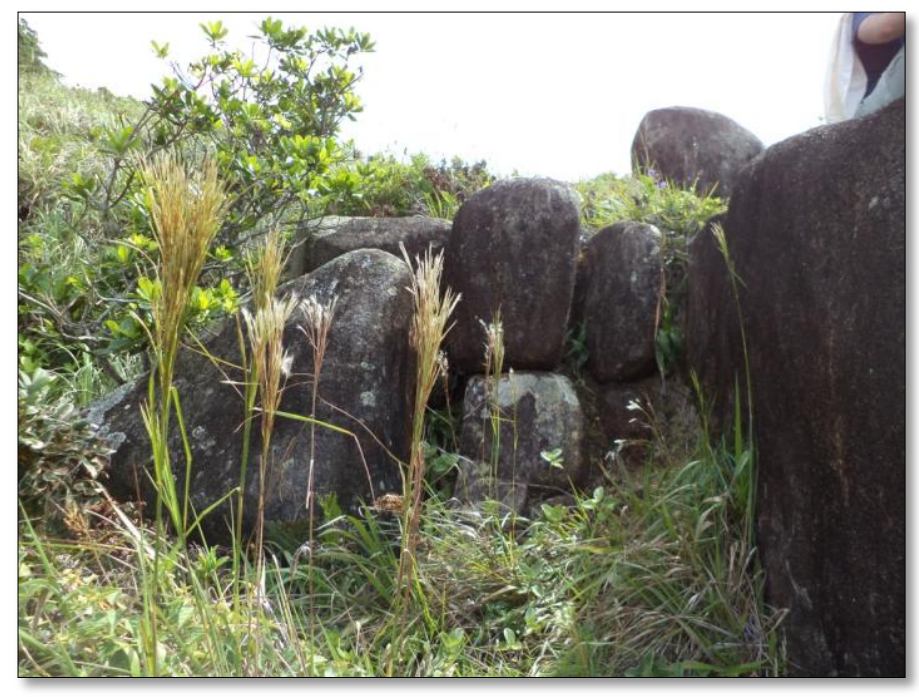

Figura 4.6.6a - A disposição dos blocos no topo do Buraco do Cação sugere que a rocha era um bloco único, que fraturou em duas direções quase ortogonais entre si, por onde os agentes de intemperismo agiram.

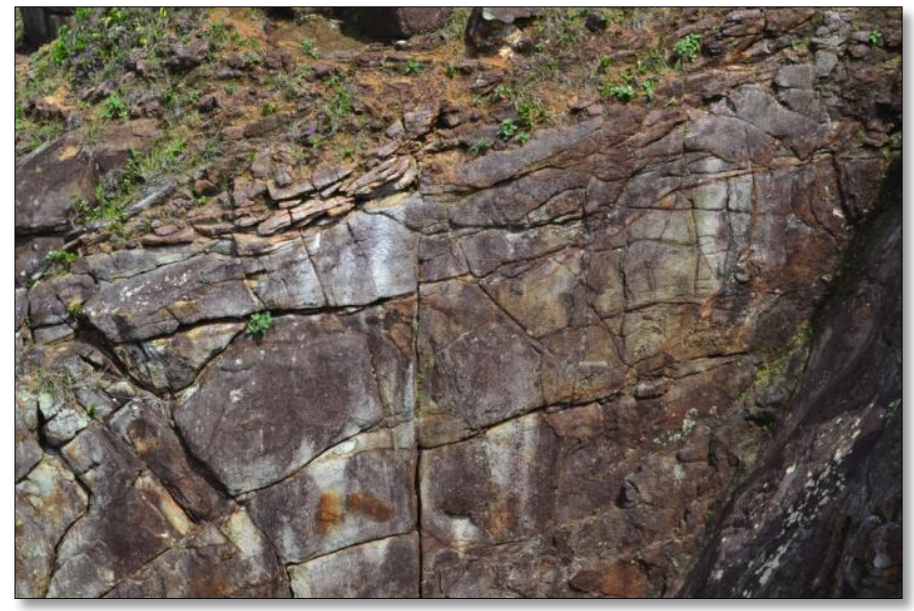

Figura 4.5.6b - A fratura da rocha segue preferencialmente direções quase ortogonais entre $\mathrm{si}$, e o intemperismo molda blocos de rochas que se assemelham a cubos de arestas arredondadas. (Foto: Erick Mota) 

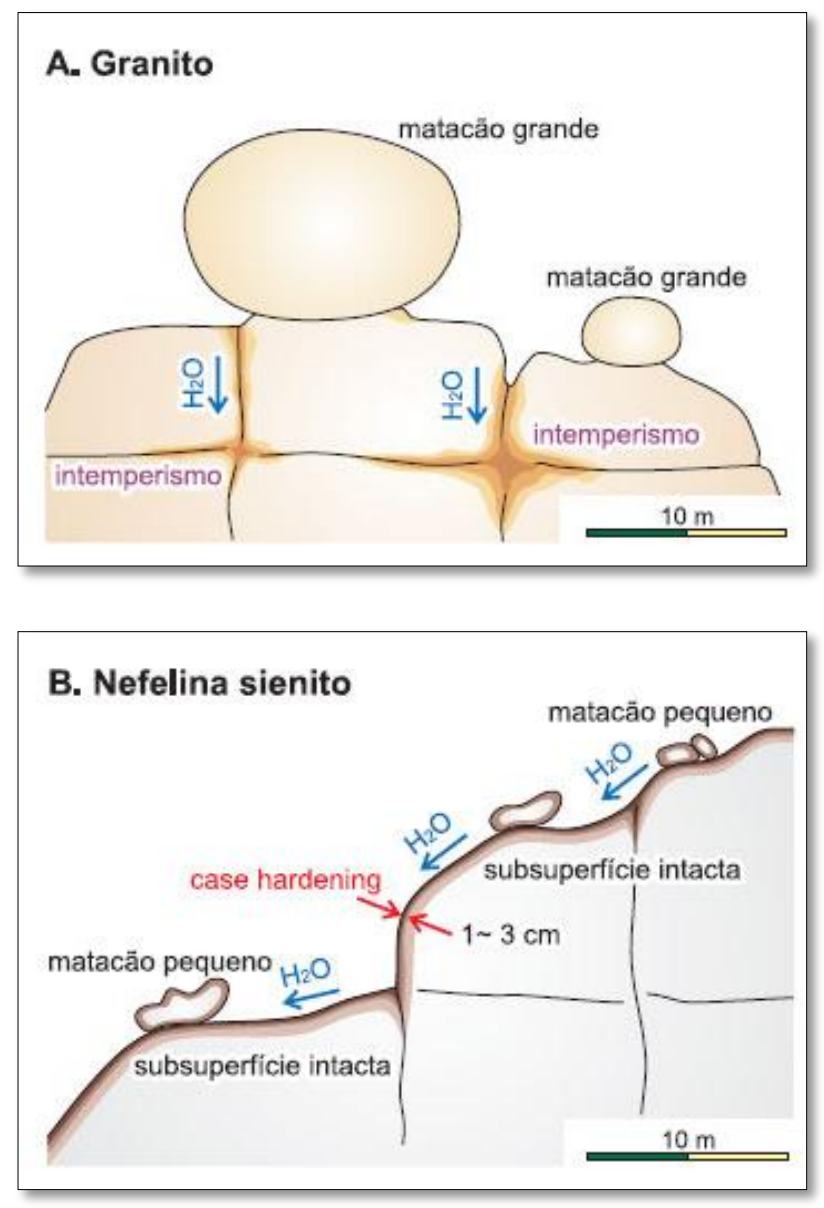

Figura 4.6.7 - As diferenças do intemperismo em rochas graníticas e nefelina sientíticas: A) No granito, a água se infiltra ao longo de fraturas de resfriamento magmático; B) na nefelina sienito, ocorre o case hardening, que protege o interior da rocha do intemperismo superficial. (MOTOKI et al, 2008)
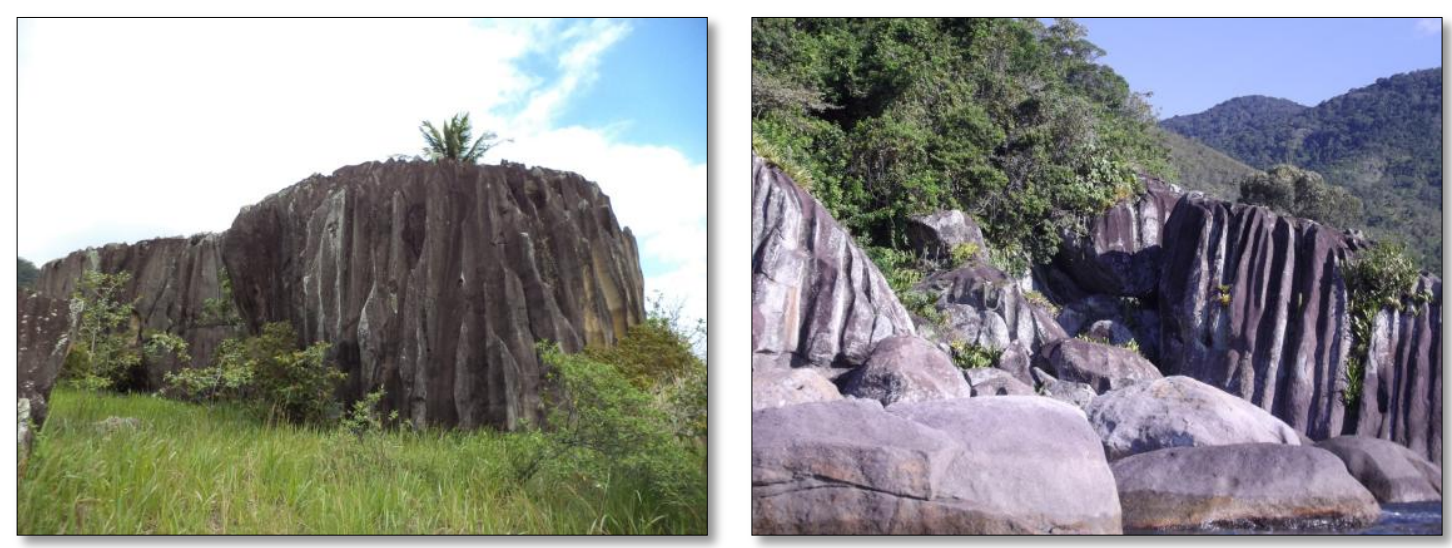

Figura 4.6.8 - Caneluras pronunciadas em blocos de rocha sienítica no bairro da Siriúba (esquerda) e na Praia do Jabaquara, no extremo norte da ilha (direita). 


\subsection{GEOSSÍTIO DIQUES DA PONTA DA SELA}

Localização (UTM): 455060 / 7352926 (Fig. 4.7.1)

Tipo: Pontual

Acesso: pela rodovia SP-131, no extremo sul da ilha. O acesso se encontra em propriedade particular e é preciso conseguir permissão para adentrar a propriedade com o proprietário do sítio, Sr. André Venco.

Dimensão: A área do costão onde se encontram os diques é de aproximadamente $4.000 \mathrm{~m}^{2}$

Unidade dentro do mapa da CPRM (2006): NPccgm - unidade granito gnáissica migmatítica do Complexo Costeiro: hornblenda-biotita gnaisse granitoide porfiróide e augen gnaisse. Idade entre 647 e $578 \mathrm{Ma}(\mathrm{U}-\mathrm{Pb})$.

Justificativa do valor científico: Nesta porção do costão rochoso, o granito porfirítico é cortado por diques de diabásio e um de lamprófiro, cujas relações hierárquicas são bastante didáticas e revelam informações a respeito do campo de esforços associado à abertura do Atlântico Sul.

Elementos principais de interesse: A rocha encaixante é um granito porfirítico com fenocristais de feldspatos de até $3 \mathrm{~cm}$ de comprimento. $\mathrm{O}$ granito apresenta diques pegmatíticos félsicos, enclaves básicos e orientados e algumas porções com indícios de milonitização (Fig. 4.7.2).

Os minerais essenciais do granito são quartzo e feldspato e biotita em menor quantidade. Há predomínio de plagioclásio sobre feldspato alcalino. O granito porfirítico é cortado por um dique lamprófiro e vários (cerca de 20) diques de diabásio (Fig. 4.7.3). Os diques de diabásio apresentam ripas de plagioclásio e piroxênio granular como minerais essenciais e biotita e opacos como minerais acessórios. O dique lamprófiro apresenta fenocristais de feldspato, e piroxênio, pagioclásio e opacos como minerais principais (HIGA, 2011).

Um diagrama contendo os diques e suas relações, extraído de Higa (2011) pode ser visto na Fig. 4.7.4. Os diques cortam a rocha encaixante segundo contatos 
retilíneos, sugerindo que se instalaram em regime rúptil. Também apresentam chifres e pontas quebradas como feições de borda (fig. 4.7.5), que podem indicar o sentido do fluxo do magma durante a colocação dos diques. É também possível observar indicadores cinemáticos em alguns diques, como estrias nas paredes (Fig. 4.7.6). Segundo Higa (2011), alguns indicadores cinemáticos dos diques sugerem principalmente movimentação dextral; ao passo que em juntas não preenchidas e no dique lamprófiro, sugerem movimentação sinistral.

Neste afloramento, há uma interação digna de nota entre diques de composições diferentes: o dique lamprófiro desloca o dique de diabásio, (Fig. 4.7.7), ilustrando o que é indicado por diversos autores, que afirmam que o magmatismo toleítico (onde se encaixam os diques de diabásio) ocorreu entre 102,5 e 73,5 Ma, enquanto o magmatismo alcalino (e, consequentemente, os diques lamprófiros), ocorreu há ca. 80 Ma (AMARAL et al, 1966; HENNIES \& HASUI, 1968; SONOKI \& GARDA, 1988).

Higa (2011) estudou as relações entre os diques deste afloramento e de mais outros 3 locais da ilha e as comparou. Com isso, identificou quatro famílias de juntas, F1 (NE), F2 (NW), F3 (N-S) e F4 (E-W), que conclui serem contemporâneas. Higa também concluiu as direções de compressão e distensão concordando com os dados já descritos na literatura por Riccomini (1995) e Silva \& Riccomini (2005): os enxames de diques cretáceos do segmento Santos-Rio de Janeiro e Florianópolis se colocaram na fase distensiva, respeitando as direções de compressão e distensão NNE-SSW (SHmáx) e SSE-WNW (SHmin).

Finalmente, Higa (2011), ao analisar as relações entre os diques deste afloramento, sugere que ele seja uma ilustração bastante didática desta parte da história geológica desta porção do continente.

Outros tipos de interesse: Didático (nível universitário) e turístico. O proprietário do local abriu uma trilha para garantir acesso ao afloramento, com a intenção de promover a visitação.

Uso potencial: Científico, didático e turístico.

Vulnerabilidade: Natural baixa. Antrópica baixa: o acesso a esse geossítio é através de propriedade particular, o que pode restringir a visitação. 


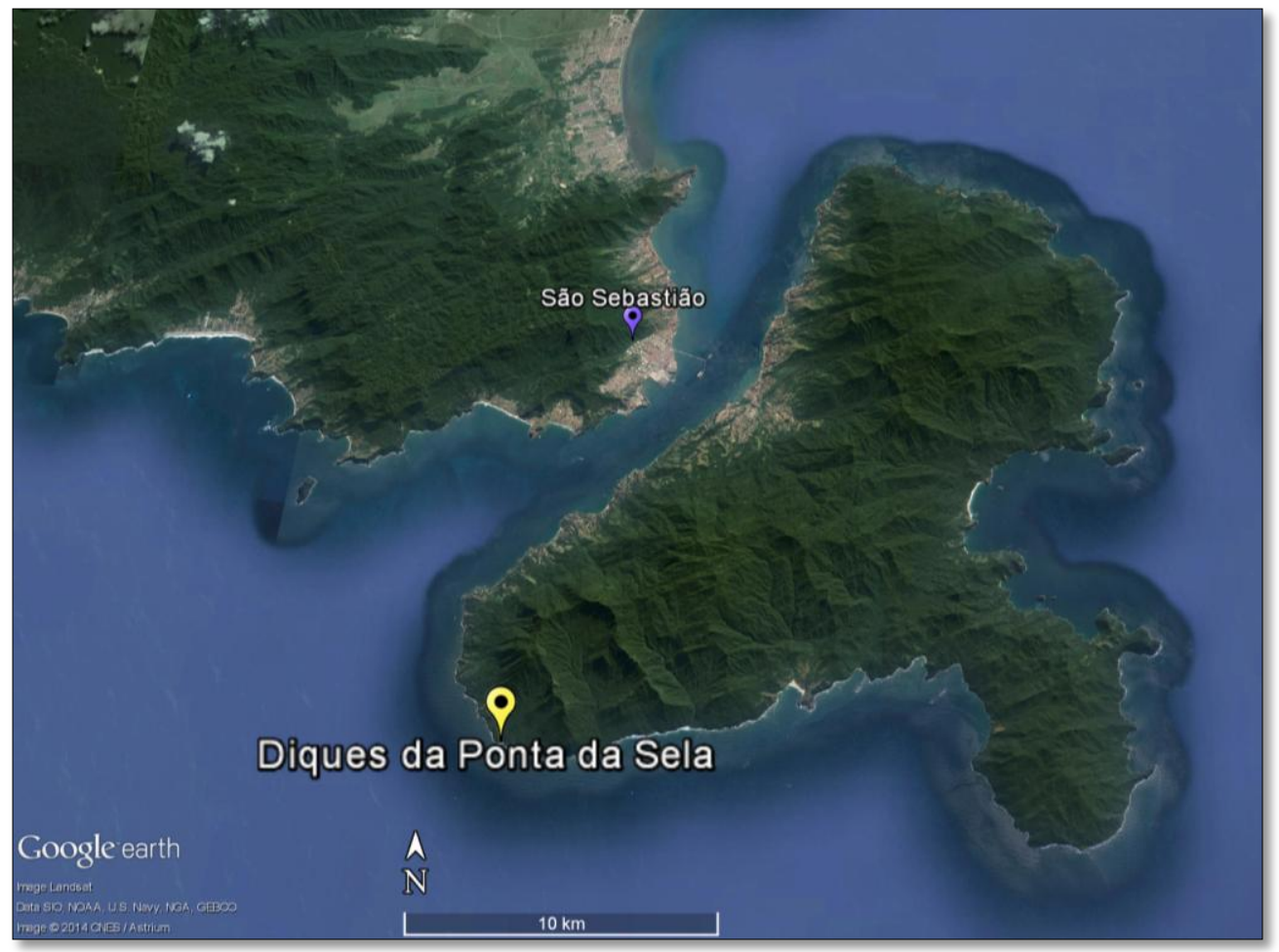

Figura 4.7.1 - A localização do geossítio Diques da Ponta da Sela na ilha de São Sebastião.
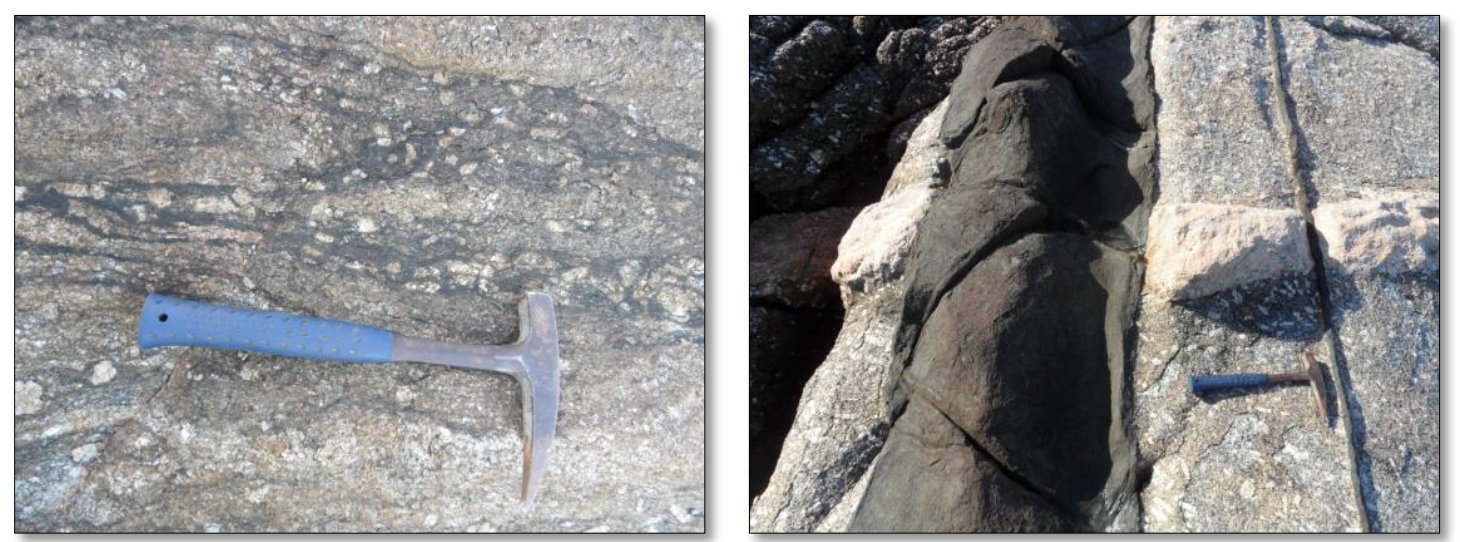

Figura 4.7.2 - Porção da rocha encaixante com indícios de milonitização ( esquerda) e dique pegmatítico félsico (direita). (Foto: Maria da Glória Motta Garcia). 


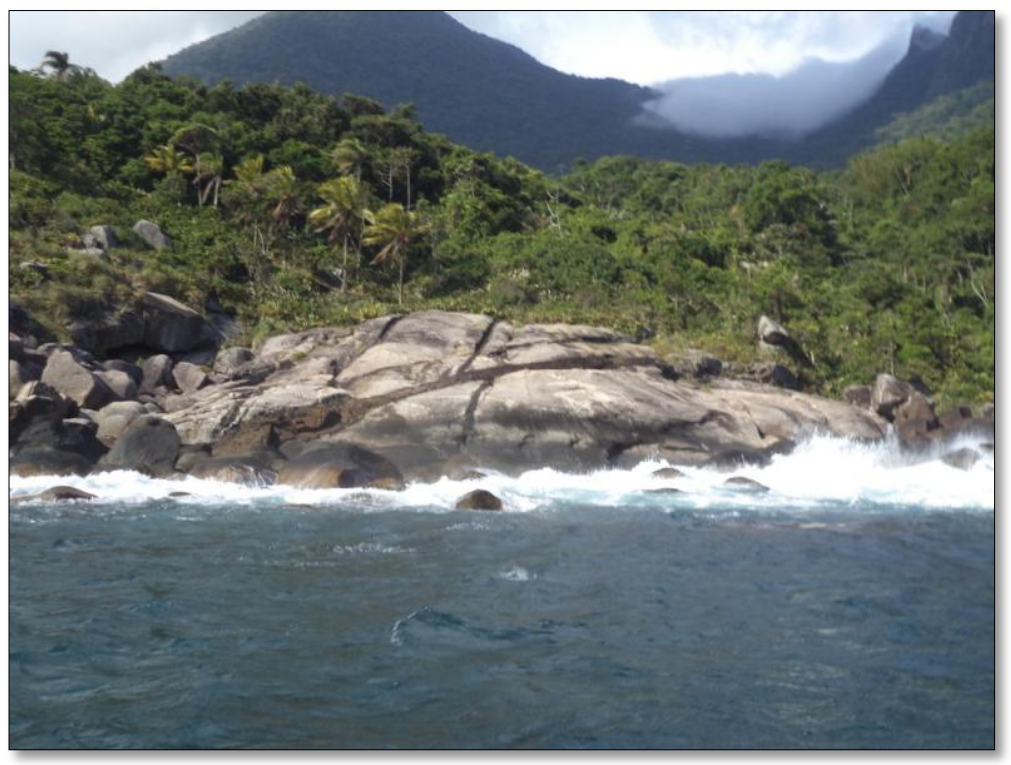

Figura 4.7.3 - Parte do costão de granito porfirítico, cortado pelos diques, visto pelo mar.

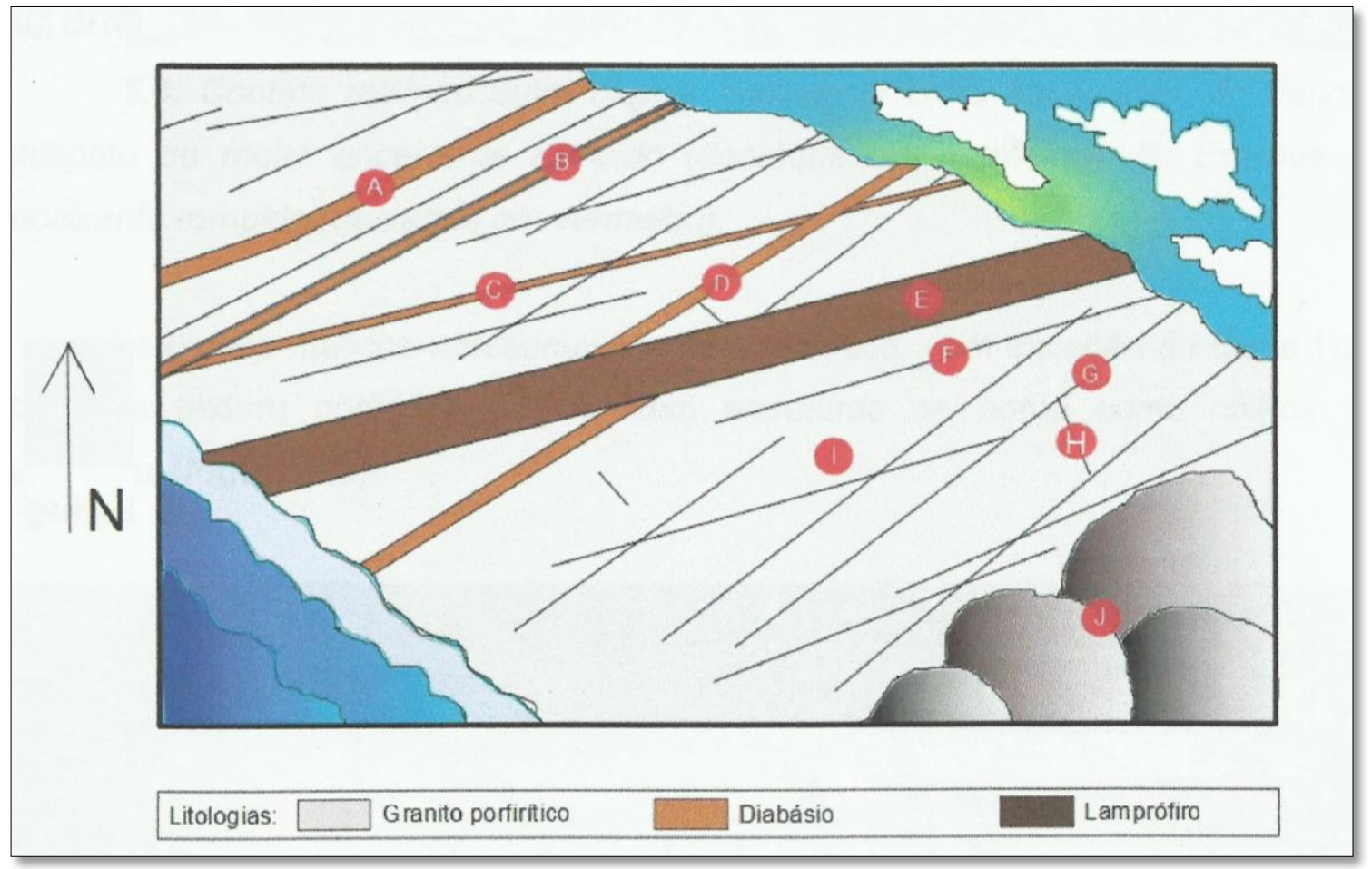

Figura 4.7.4 - Desenho esquemático do afloramento modificado de Higa (2011) com todos os diques máficos. I: rocha encaixante dos diques. J: blocos de rocha não in situ. Diques em F1: A, B, D.. Diques em F4: C, E. F: F4. G: F1. H: F2. 

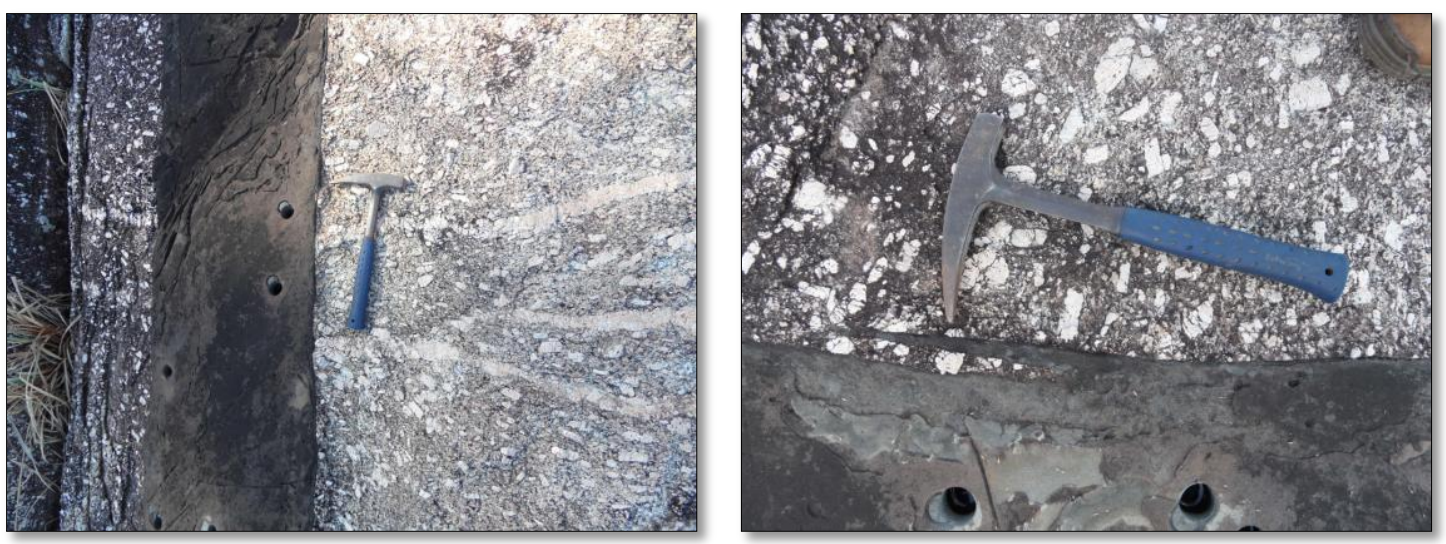

Figura 4.7.5 - Contato retilíneo entre o dique a rocha encaixante (esquerda). À direita, feição de borda no dique (chifre), indica o fluxo magmático (para a esquerda, na foto) na ocasião em que o dique se instalou. (Foto: Maria da Glória Motta Garcia).

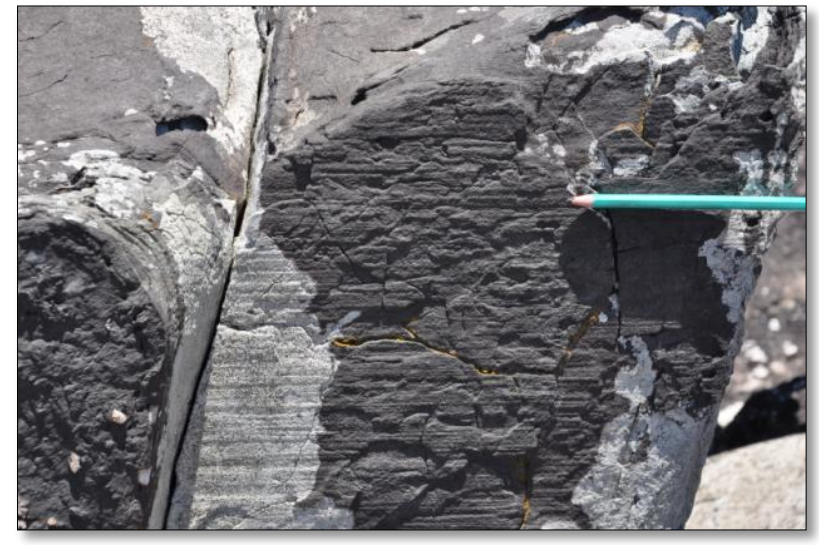

Figura 4.7.6 - Estrias nas paredes do dique de lamprófiro, que indicam direção de movimento subhorizontal na direção N40. (Foto: Eliane Del Lama) O dique lamprófiro interrompe e desloca o dique de diabásio, como se pode ver na próxima figura.

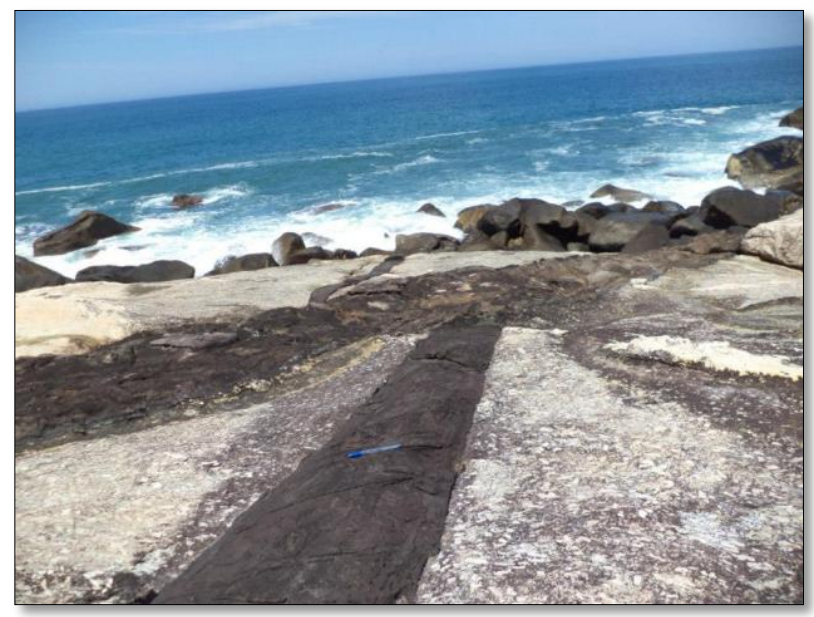

Figura 4.7.7 - Os diques entrecortantes: neste ponto, o dique de diabásio (D, na fig.4.7.4) é interrompido e deslocado pelo dique lamprófiro (E, na fig. 4.7.4) 


\subsection{GEOSSÍTIO GABROS ESTRATIFORMES}

Localização (UTM): 0454134 / 73554259 (Fig. 4.8.1)

Tipo: Perfil

Acesso: através de uma trilha que sai do fundo da Pousada Oito llhas, à Av. Gov. Mario Covas Jr, 17518.

Dimensão: a área de interesse do costão rochoso tem aproximadamente $5000 \mathrm{~m}^{2}$.

Unidade dentro do mapa da CPRM (2006): NPccgm - unidade granito gnáissica migmatítica do Complexo Costeiro: hornblenda-biotita gnaisse granitoide porfiróide e augen gnaisse. Idade entre 647 e $578 \mathrm{Ma}(\mathrm{U}-\mathrm{Pb})$.

Justificativa do valor científico: Neste local é possível observar o gabro estratiforme, seu contato com o granito porfirítico, enclaves gabróicos, um dique bandado e porções do gabro com textura vuggy preenchida por anfibólio acicular, exemplificando dinâmicas da câmara magmática, processos petrogenéticos e sugerindo a possibilidade de que este seja um ponto onde se possa investigar o magmatismo alcalino e suas associações na região, já que ainda não foi estudado. Além disso, é um afloramento de feições contínuas, diferentemente do que acontece com os gabros estratiformes do norte da ilha, que afloram em forma de blocos rolados.

Elementos principais de interesse: Partindo-se de sua porção norte, pode-se encontrar o gabro com textura cumulática e bandamento (Fig. 4.8.2) que podem ser sugestivos de processos como flotação, acumulação gravitacional, correntes de convecção e filter pressing. Pode-se observar ainda um dique intrudindo outro dique, exibindo contatos definidos e com texturas diferentes (o interno e mais novo, afanítico, e o externo e mais antigo, porfirítico) (Fig. 4.8.3) e enclaves gabróicos supostamente autolíticos e de aparente predominância félsica (Fig. 4.8.4).

Em um ponto acessível somente com a maré mais baixa, ainda mais ao sul, é visível o gabro com textura vuggy preenchida por anfibólio acicular (Fig. 4.8.5). Por quais formas a água entrou neste sistema, possibilitando a cristalização de anfibólio, 
somente investigações mais pontuais podem elucidar, porém pode-se supor algumas hipóteses. Este pode ter sido o topo da câmara magmática, onde o gabro, em estado semi-plástico, teria desenvolvido os vazios, preenchidos por líquidos hidrotermais da fase tardia de cristalização magmática. Outra possibilidade é a de que os diques mais recentes tenham trazido essa água, que então acessou o gabro, em estado rúptil, através de fraturas e possibilitou a cristalização do anfibólio.

Finalmente, próximo ao ponto mais a sul, encontramos o contato entre 0 gabro e um granito porfirítico, que é o mesmo que aflora ao longo da parte ocidental da ilha (Fig. 4.8.6). Este é um dos poucos contatos acessíveis entre o gabro estratiforme e o granito porfirítico da ilha conhecidos até o momento, em sua porção do extremo sul. Ao percorrer o geossítio de seu limite norte a seu limite sul, portanto, observam-se vários exemplos de dinâmicas da câmara magmática. Porém e infelizmente, nada se pode afirmar com certeza a respeito de cada ponto, pois é necessário que se façam estudos muito mais completos sobre as rochas deste local para que se saiba a relação entre elas.

A associação de elementos descritos neste afloramento também suscita a hipótese de que o lugar tenha sido formado por pulsos magmáticos sucessivos, sendo, por isso, um geossítio representativo de fases da evolução magmática dos principais pulsos. De qualquer forma, este local revela evidências de dinâmica de uma câmara magmática didaticamente.

Além disso, e sob a luz das investigações feitas no norte da ilha, há indícios de que a associação de tipos litológicos neste geossítio possivelmente ilustre processos relacionados ao magmatismo alcalino da província Serra do Mar e, em um contexto geotectônico mais abrangente, da abertura do Atlântico Sul, conforme foi sugerido por Lima (2001), Lima \& Schorscher (1999) e Schorscher \& Lima (2001).

O estudo das rochas alcalinas com suas associações é importante para a compreensão da evolução dos mantos asteno e litosférico e da margem continental SE do Brasil no Mesozóico (AUGUSTO, 2003). Segundo Ulbrich \& Gomes (1981), a associação das rochas alcalinas félsicas com rochas gábricas, em geral estratificadas e de filiação alcalina, é característica de vários dos maciços alcalinos da Província Serra do Mar, incluindo a llha de São Sebastião. Vários autores (BELLIENI et al. 1990; FREITAS, 1947; HENNIES \& HASUI 1977) afirmam que junto 
aos stocks de Ilhabela se associam gabros, diques de diabásio, de rochas lamprófiras ultramáficas e alcalinas e rochas alcalinas félsicas.

Lima (2001) estudou as intrusões gábricas estratiformes que afloram na parte Norte da ilha, em mar de blocos. Estas intrusões cortam o granito-gnáissico e migmatítico pré-cambriano do Complexo Costeiro em duas gerações: uma inicial do magmatismo mesozóico, de diques básicos-ultrabásicos (diabásios seguidos de lamprófiros) e uma secundária, de diques básicos a intermediários (basaltos a dacitos). Os litotipos principais dos corpos gábricos estratiformes são leuco e mesogabros, seguidos de piroxenitos, anortositos e peridotitos. Vêem-se neles estruturas de sedimentação magmática (bandamento/acamamento plano-paralelo, bandamento rítmico, estratificação gradacional), estruturas de deformação gravitacional e brechas de borda e reintrusão da câmara magmática.

Os estudos de Lima apontam para mecanismos de intrusões múltiplas gerando corpos gábricos de duas linhagens principais: uma de gabros subalcalinos e toleíticos e outra de gabros alcalinos nefelínicos (ambas com respectivos diferenciados de câmara magmática - peridotitos, piroxenitos e anortositos). Reintrusões ocasionaram brechas de câmara magmática com fragmentos de gabros e seus diferenciados em matrizes gábricas (AUGUSTO, 2003).

Augusto (2003) descreveu amostras de gabro do sul da ilha, retiradas de afloramentos nos cortes de estrada muito próximos a este local (Fig 4.8.7): rochas de granulação média e cores escuras, em que se destacam cristais ripiformes de plagioclásio e piroxênio com estruturas em geral homogêneas, maciças, ou levemente bandadas (neste caso, intercalam-se bandas milimétricas mais ricas em plagioclásio com bandas mais ricas em silicatos máficos ou ainda mais ricas em minerais opacos); texturas equigranulares a seriadas. O aspecto bandado é dado pela concentração preferencial de plagioclásio, silicatos máficos, e/ou minerais opacos e anfibólio e mica intersticial.

Lima \& Schorscher (1999) afirmam que na Ponta da Pacuíba, na região mais a Norte da ilha, há indícios de diferenciação in situ (corroborados por elementos traço), fazendo inferir a relação entre grupos ígneos mesozóicos e possíveis fontes mantélicas. As rochas intrusivas cogenéticas (cálcio-alcalinas ou toleíticas subalcalinas), os sienitos e diques básicos, e os gabros estratiformes da llhabela (e análogos de outras ilhas e imediações do litoral continental), parecem estar 
relacionadas a uma associação geotectônica mais abrangente, com especificidades asteno-litosféricas termais, composicionais e tectônicas, inerentes à abertura do Atlântico Sul (SCHORSCHER \& LIMA, 2001).

Outros tipos de interesse: Didático (nível universitário).

Uso potencial: Científico e didático. O acesso não é fácil e não é uma localidade de beleza estética para turistas. Por isso, seu valor é prioritariamente científico e didático a nível universitário, especialmente para as disciplinas de Petrologia Ígnea.

Vulnerabilidade: Natural baixa. Antrópica baixa.

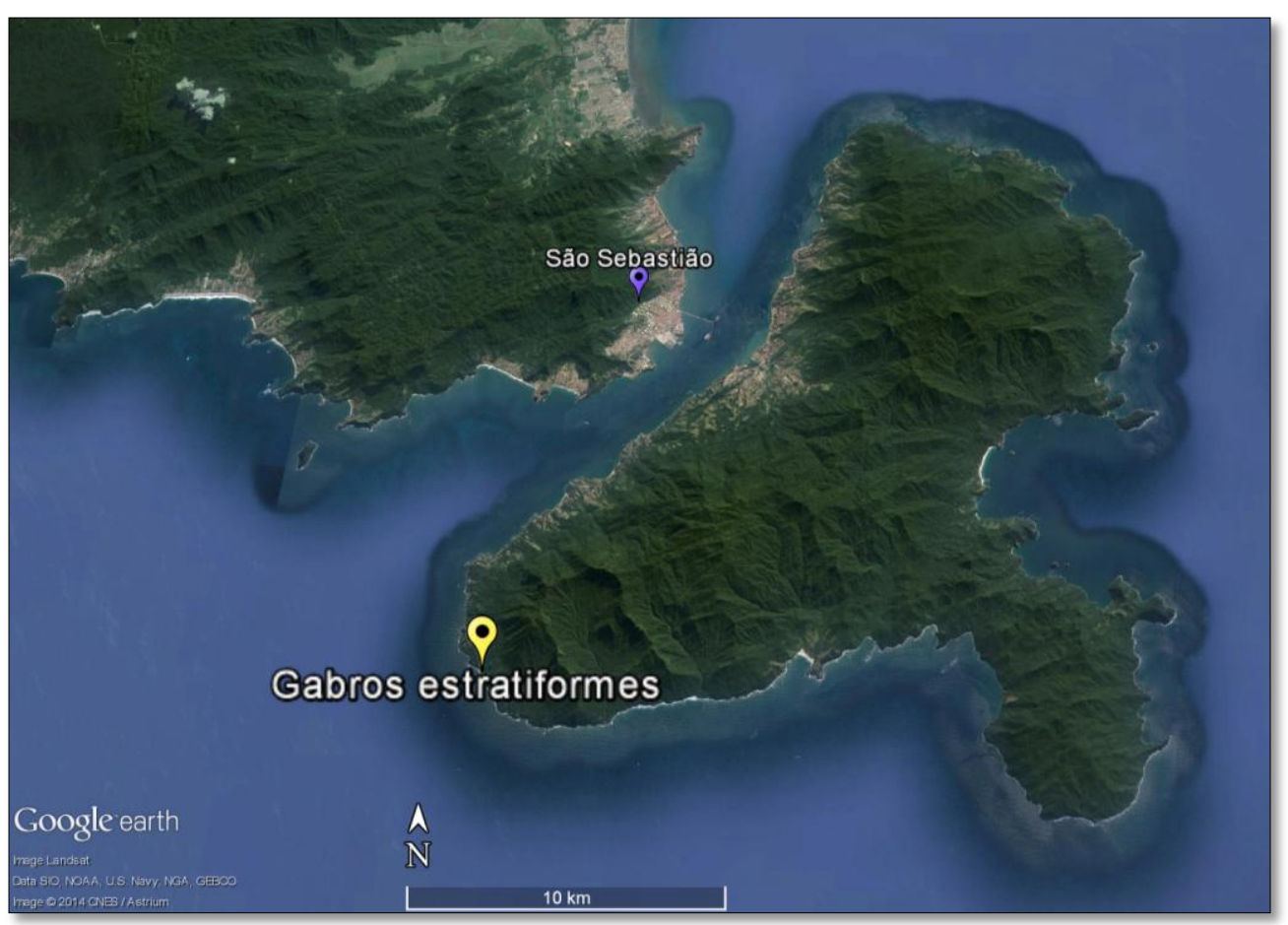

Figura 4.8.1 - Localização do geossítio Gabros Estratiformes na ilha de São Sebastião. 


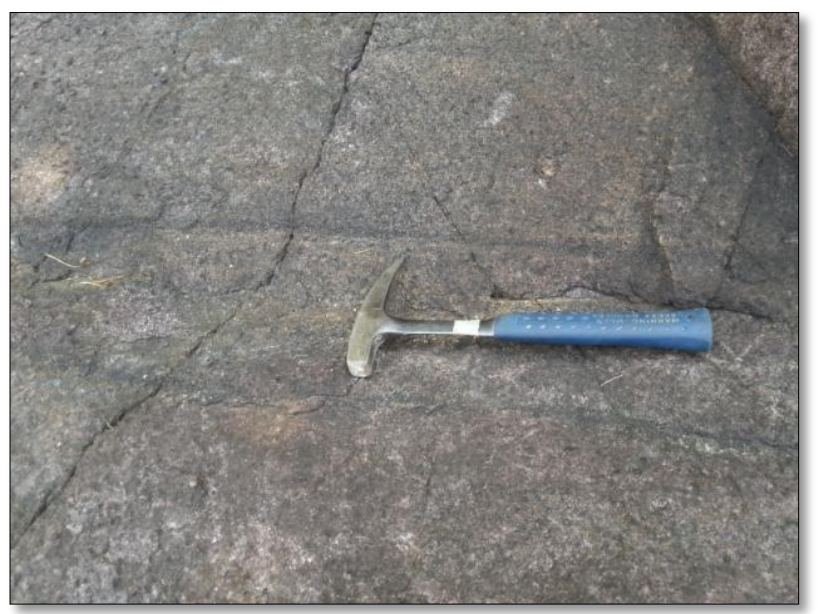

Figura 4.8.2 - O gabro estratiforme, com bandamentos félsicos e máficos, que podem indicar filter pressing na câmara magmática.

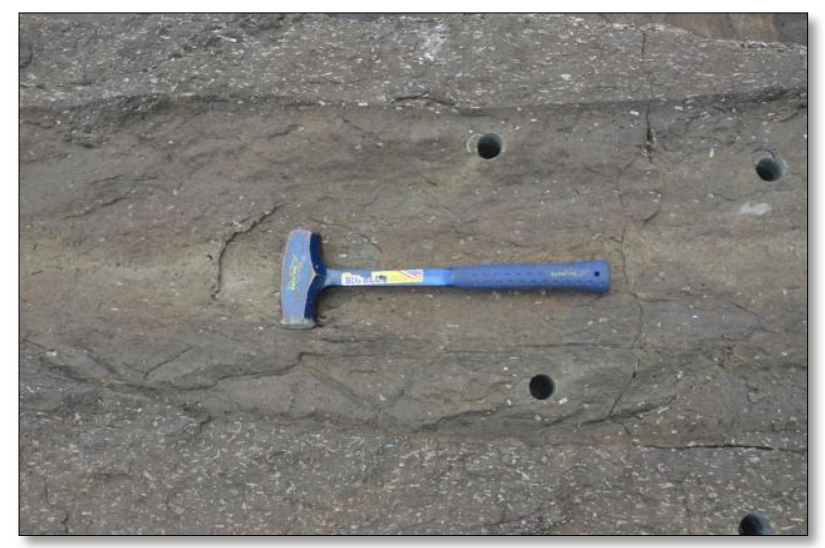

Figura 4.8.3 - Dique intrudindo dique, com contatos definidos e com texturas diferentes (o interno e mais novo, afanítico, e o externo e mais antigo, porfirítico) (Foto: Maria da Glória Motta Garcia)

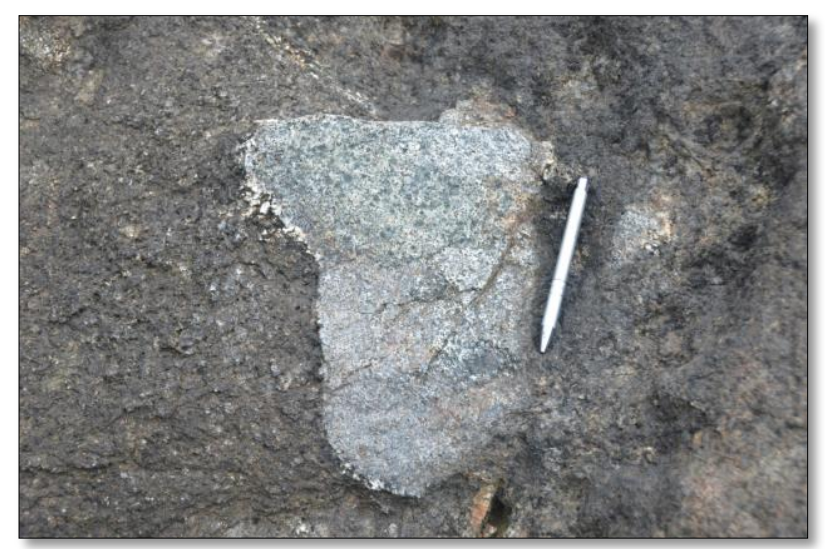

Figura 4.8.4 - Enclave gabróico autolítico de aparente predominância félsica na rocha encaixante, também gabro: o estudo destas relações pode revelar mais sobre a dinâmica magmática que se estabeleceu ao redor dos maciços alcalinos. 

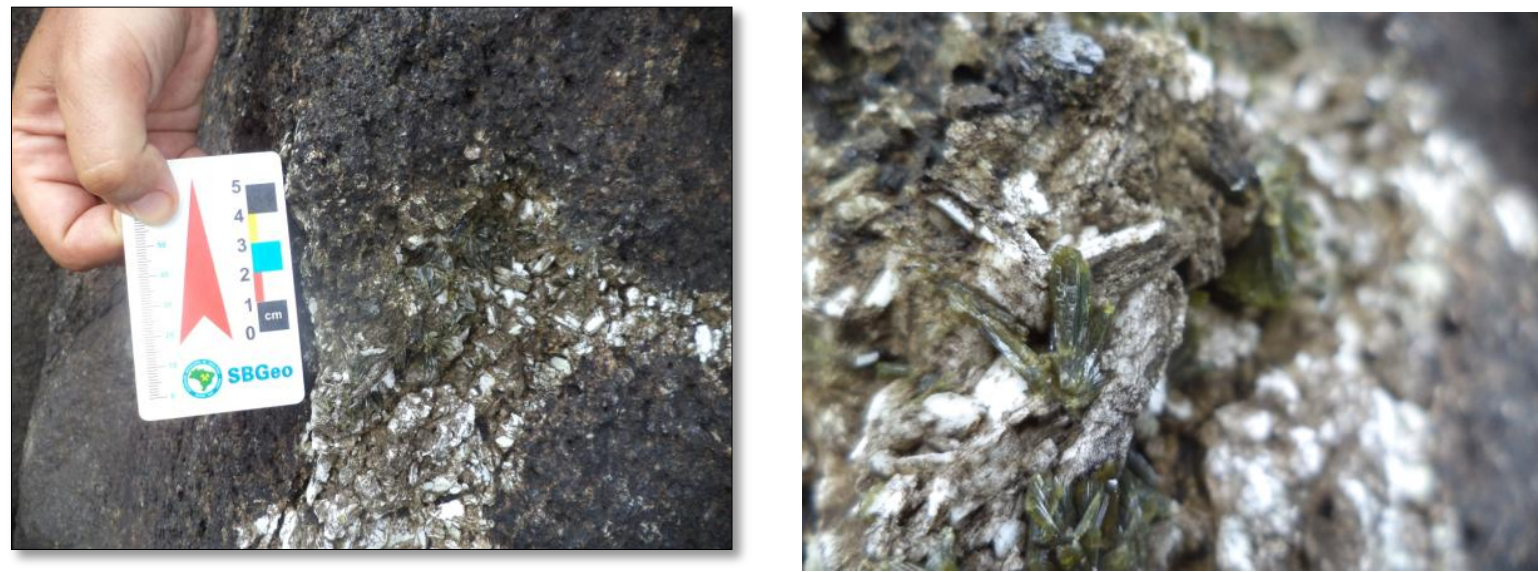

Figura 4.8.5 - O crescimento de anfibólio acicular preenchendo textura vuggy no gabro (detalhe à direita)

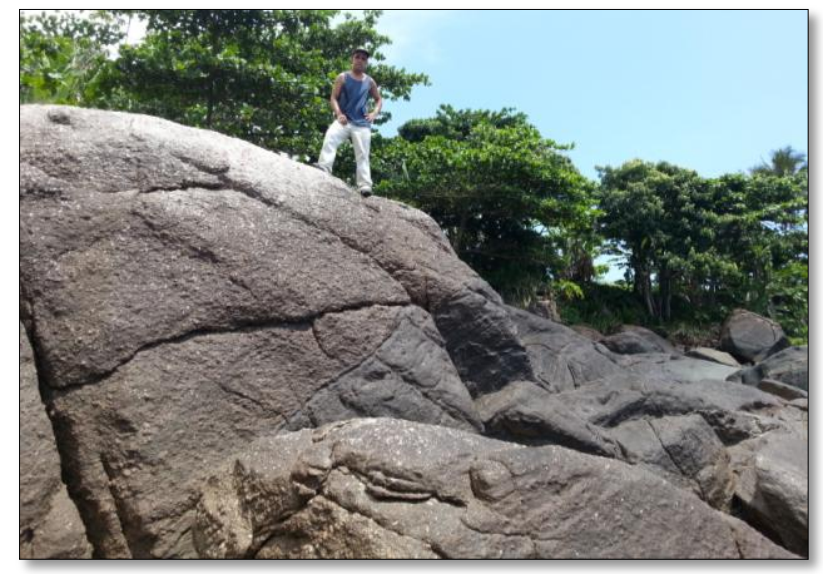

Figura 4.8.6 - Na ponta sul do geossítio, o contato entre granito porfirítico, presente em várias partes da ilha, e o gabro.

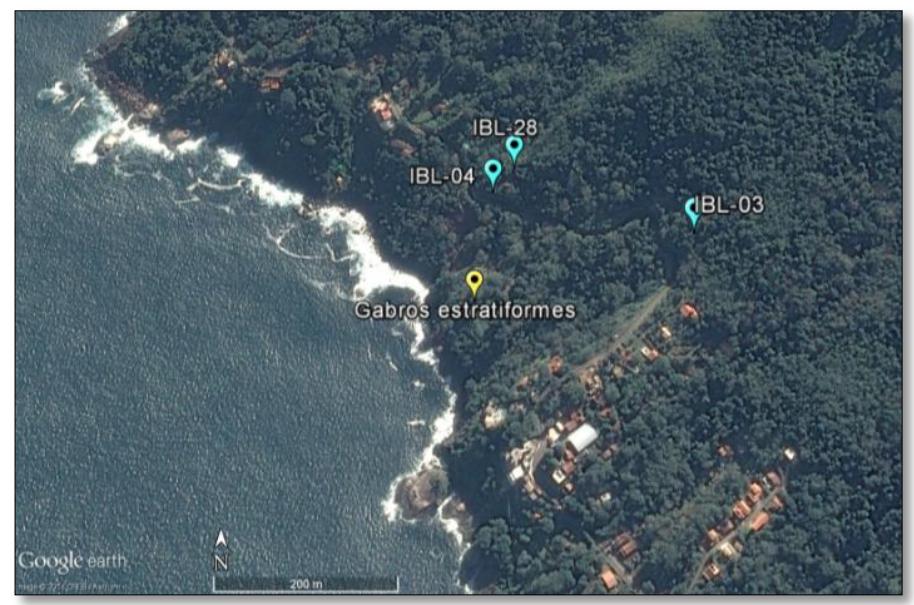

Figura 4.8.7 - Localização de pontos de coleta das amostras IBL-03, IBL-04 e IBL-28 de gabro investigadas por Augusto (2003) e próximas ao local proposto para este geossítio. 


\subsection{GEOSSÍTIO PRAIA DO PORTINHO}

Localização (UTM): inicial 0458531 / 7363002 (Fig. 4.9.1)

Tipo: Pontual

Acesso: Através de servidão pública que se inicia na rodovia SP-131, ou, conforme denominada localmente, Av. Riachuelo (antiga Av. Brasil). $\mathrm{O}$ acesso à praia é livre. $\mathrm{O}$ acesso direto ao ponto onde as rochas afloram passa por propriedade privada.

Dimensão: trata-se de um costão rochoso de aproximadamente $100 \mathrm{~m}$ de extensão na Praia do Portinho.

Unidade dentro do mapa da CPRM (2006): NPccog - unidade ortognáissica neoproterozóica do Complexo Costeiro: ortognaisse migmatítico cálcio-alcalino, (hornblenda)-biotita granitóideprofiróide e augen gnaisse.

Justificativa do valor científico: Os tipos litológicos deste local e o modo como estão relacionados entre si exemplificam momentos distintos da história geológica regional - mais expressivamente o choque de placas que resultou na amalgamação do Gondwana (ca. $600 \mathrm{Ma}$ ) e, posteriormente, na abertura do Oceano Atlântico Sul (ca. $140 \mathrm{Ma})$.

Elementos principais de interesse: $O$ local se caracteriza por um afloramento de costão de cerca de $100 \mathrm{~m}$ de comprimento. Nos primeiros $40 \mathrm{~m}$, observa-se de gnaisse bandado com veios félsicos de espessura variando de subcentimétrica até cerca de $40 \mathrm{~cm}$ (Fig. 4.9.2a/b). Uma camada principal de leucogranito grosso, de cerca de $20 \mathrm{~cm}$ de espessura e concordante com o gnaisse, apresenta feldspatos subeuédricos e bem desenvolvidos e quartzo e muscovita em quantidade subordinada (Fig. 4.9.3).

Após estes 40 metros iniciais, o costão passa a apresentar outros tipos litológicos, na forma de camadas contínuas e também de blocos rolados, resultado do intemperismo que quebrou e rolou os pedaços de rochas diferentes entre si. Estes tipos litológicos são encontrados igualmente em uma porção que não foi tão erodida e que, por isso, forma uma parede de cerca de $10 \mathrm{~m}$ de largura. 
Nesta parede podem ser observadas camadas sub-horizontais de gnaisse bandado com veios quartzo-feldspáticos, intercaladas por leucogranito grosso e por lentes de rochas calciossilicáticas com veios leucocráticos, paralelizadas (Fig 4.9.4). Há também a presença de diques máficos em direção preferencial concordante com as das camadas das litologias adjacentes (Fig 4.9.5).

O gnaisse apresenta bandas nematogranoblásticas e granonematoblásticas. Intercalam-se à estrutura bandada e estiram-se veios félsicos de granulação média. As rochas calciossilicáticas têm coloração escura, esverdeada e estrutura bandada e podem exibir veios quartzo feldspáticos de 1 a $2 \mathrm{~cm}$ de espessura, dobrados. Ocorrem em forma de boudins de cerca de $1 \mathrm{~m}$ de espessura, apresentando dobras intrafoliais fechadas, cujos eixos são subparalelos à lineação de estiramento do gnaisse (Fig. 4.9.6 - BARRETO, 2012). Isso leva a imaginar que sejam contemporâneas ao evento que produziu os dobramentos e consequente foliação no gnaisse.

Uma imagem da parede com os boudins pode ser vista na figura 4.9.7.

$\mathrm{O}$ afloramento é ilustrativo de grandes eventos geológicos que ocorreram na região em momentos distintos. Sugere-se que a deformação imposta ao protólito que originou o gnaisse tenha ocorrido no Paleoproterozoico; que o basculamento e dobramento do pacote sejam resultado dos eventos neo-proterozoicos associados à colisão de placas, que resultou na amalgamação do supercontinente Gondwana, no segundo dos dois ciclos orogênicos panafricanos-brasilianos, finalizado no Cambriano Médio, há ca 600 Ma (TROMPETTE et al., 1993); e que, finalmente, a colocação do leucogranito tenha sido quase concomitante àquela dos diques máficos e toleíticos em toda a extensão do litoral norte, remontando ao evento de quebra do Gondwana no Neocretáceo ou em reativações posteriores de falhas, no Neo-paleoceno.

Outros tipos de interesse: Didático (nível universitário)

Uso potencial: Científico e didático.

Vulnerabilidade: Natural baixa. Antrópica média: alunos da área de geociências costumam martelar o afloramento e retirar amostras. 


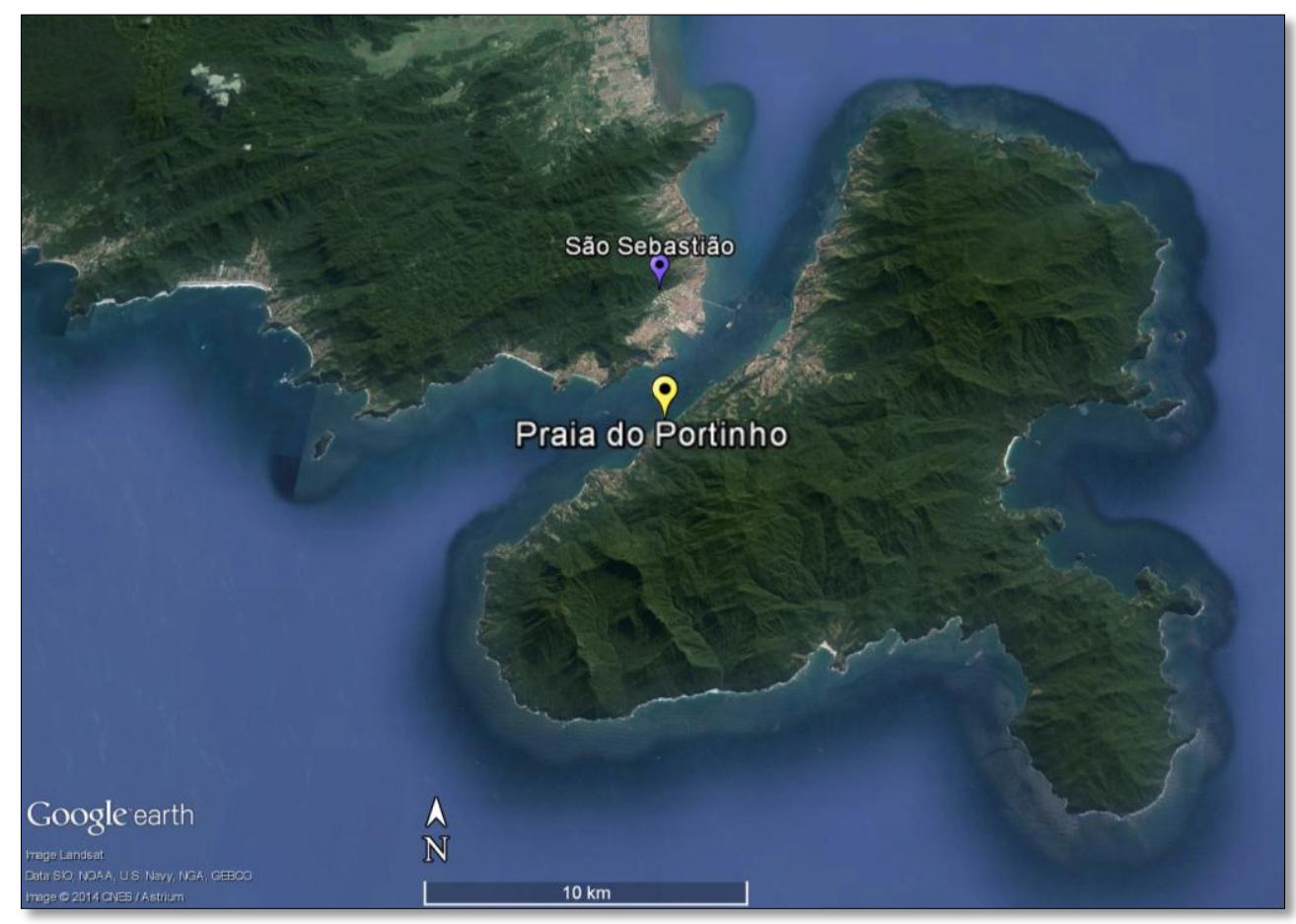

Figura 4.9.1 - Localização do geossítio Portinho, na llha de São Sebastião.

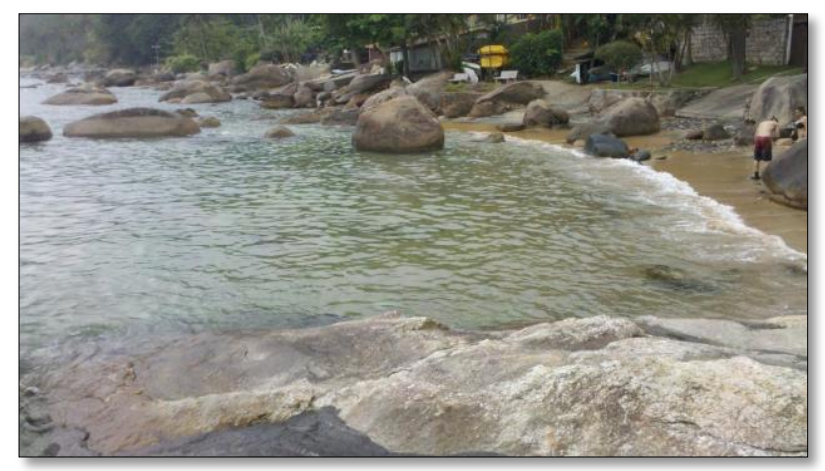

Figura 4.9.2a - O início do costão do Portinho visto de cima do afloramento de gnaisse bandado. A faixa de areia é coberta por blocos de rocha, o que faz com que a praia seja usada principalmente para pesca e mergulho e pouco por banhistas.

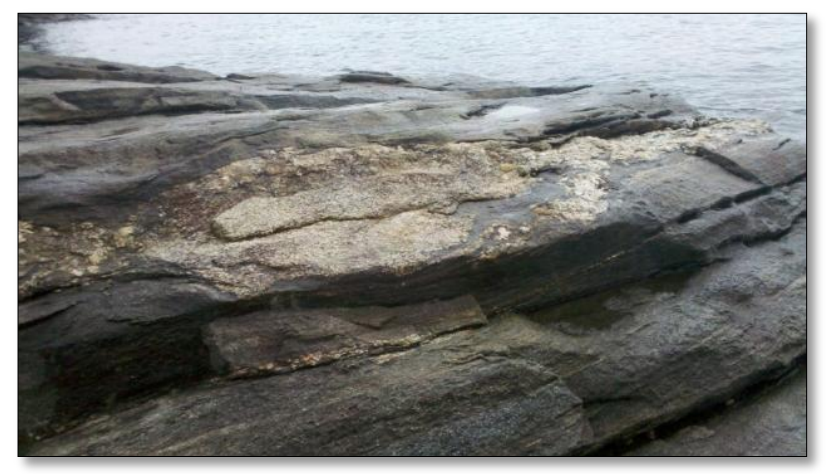

Figura 4.9.2 b - Veios leucocráticos no gnaisse bandado, de espessura subcentimétrica a dezenas de centímetros. 


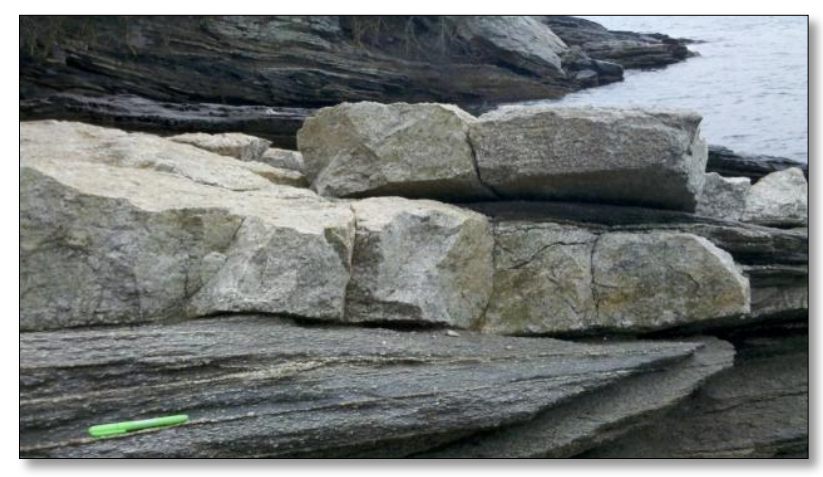

Figura 4.9.3 - Camada leucogranito grosso, de cerca de $20 \mathrm{~cm}$ de espessura e concordante com o gnaisse, apresenta feldspatos subeuédricos e bem desenvolvidos e quartzo e muscovita em quantidade subordinada.

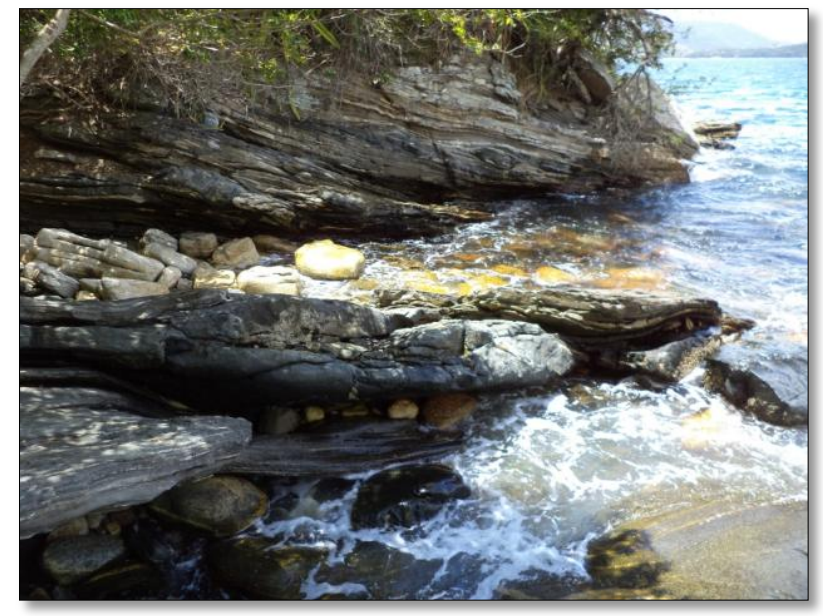

Figura 4.9.4 - Ao fundo, parede de cerca de $10 \mathrm{~m}$ de largura: gnaisse bandado com intercalações de rochas calciossilicáticas

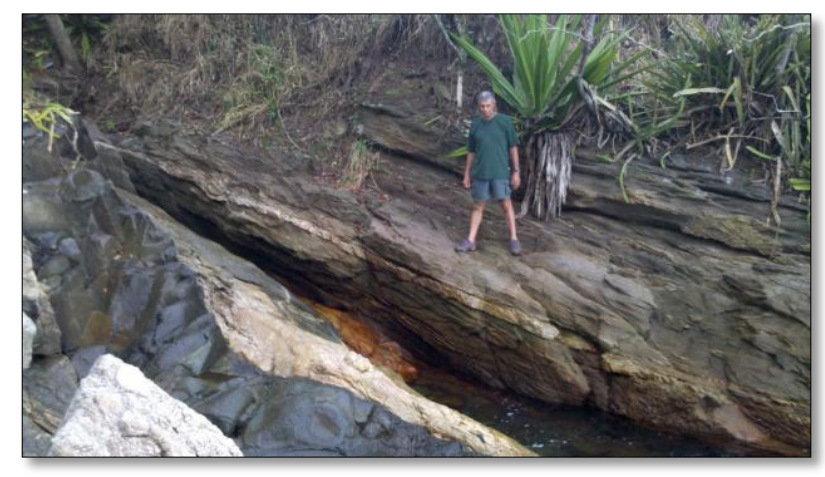

Figura 4.9.5 - Dique máfico do afloramento, concordante com a foliação. 


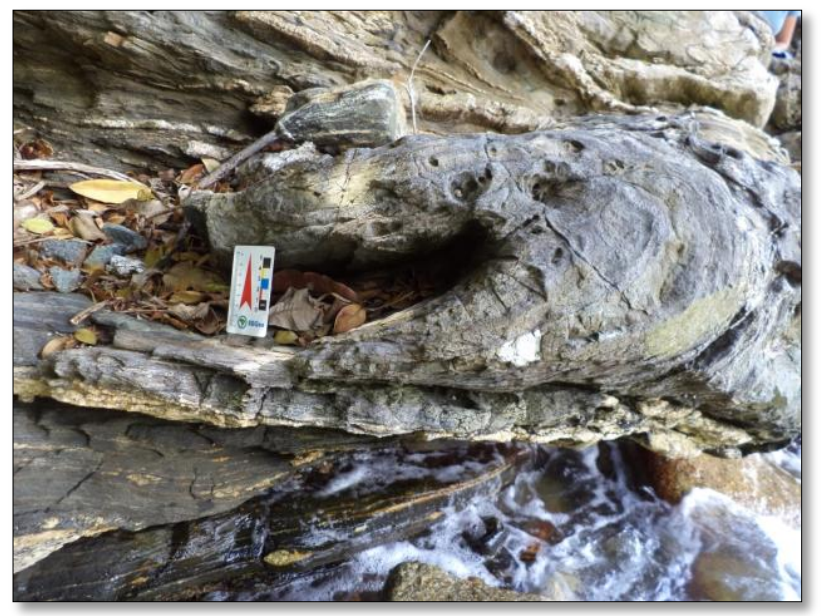

Figura 4.9.6 - Rocha calciossilicatica com foliação de transposição no afloramento do Portinho.

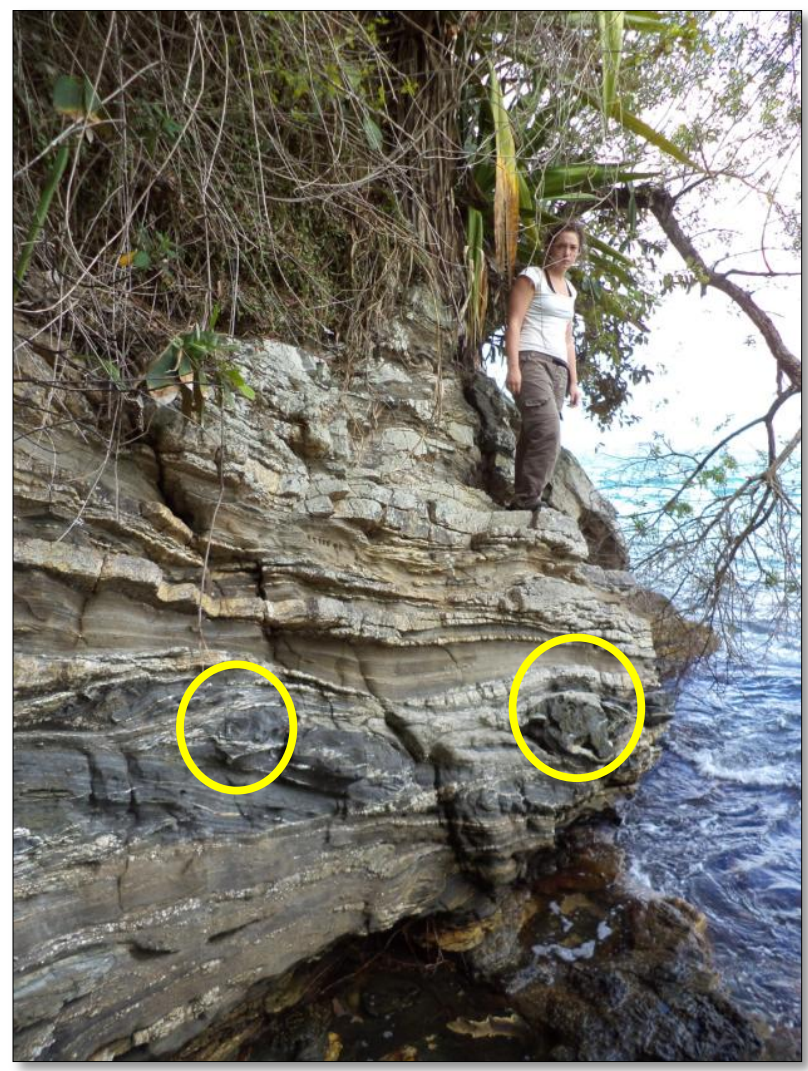

Figura 4.9.7 - A parede de gnaisse e rochas silicáticas, com os boudins indicados pelos círculos amarelos. 


\section{QUANTIFICAÇÃO}

A etapa de quantificação em um inventário de patrimônio geológico é necessária - embora nem sempre feita - especialmente em casos onde a quantidade de geossítios ultrapassa os recursos humanos e financeiros disponíveis para a implementação de ferramentas de gestão e estruturas de interpretação. Estas são parte preponderante na consecução de medidas para preservação dos locais escolhidos por sua relevância geológica.

As quantificações presentes neste trabalho, conforme já explicitado anteriormente, foram motivadas pelo fato de este projeto integrar um inventário de maiores proporções e que abrange o litoral norte do estado de São Paulo. Por si só, o número pequeno de geossítios sugeridos em llhabela e sua vulnerabilidade baixa - principalmente por estarem localizados dentro ou no limite com o Parque Estadual, por suas grandes dimensões e pela resistência das rochas da maioria deles - não demandariam uma quantificação. Entretanto, quando inseridos no contexto maior, a quantificação pode fornecer bases para a seriação e a comparação entre os vários locais levantados.

Além disso, o processo das quantificações apresentadas aqui suscitaram discussões e questões e, por isso, tanto as valorações quanto as aferições decorrentes deste exercício foram integradas a essa dissertação. Espera-se com isso contribuir com terceiros nas iniciativas futuras neste âmbito.

\subsection{A IMPORTÂNCIA DA ESCOLHA DO MÉTODO}

Conforme citado anteriormente, vários autores têm se dedicado a desenvolver métodos de quantificação que minimizem a subjetividade inerente ao processo. Dentre as iniciativas mais conhecidas, Pereira (2010) destaca e analisa os métodos de Rivas et al. (1997), Brilha (2005), Bruschi \& Cendrero (2005), Coratza \& Giusti (2005), Serrano \& Gonzalez Trueba (2005), Pralong (2005), Pereira (2006), Zouros (2007) e García-Cortéz \& Carcavilla Urqui (2009).

Todos estes métodos apresentam grandes vantagens de uso nas situações para as quais foram desenvolvidos. Por exemplo, Rivas et al. priorizaram a avaliação de impactos ambientais em geomorfossítios, Serrano \& González-Trueba pensaram 
no manejo e uso potencial de áreas naturais protegidas em escala local e Pralong tencionou avaliar os valores estéticos, científicos, culturais/históricos e social/econômicos do patrimônio geomorfológico em um contexto turístico e recreativo (PEREIRA, 2010).

Dentre as iniciativas brasileiras de desenvolvimento de um método de quantificação, além daquela mencionada anteriormente, o Geossit, merecem destaque os trabalhos de Lima (2008) e Pereira (2010). Para o inventário, Lima considerou as grandes proporções do território brasileiro e as dificuldades de se realizar um levantamento geológico, sugerindo, por isso, uma estrutura organizacional dos grupos de trabalho e incorporando conceitos cujos usos já estão arraigados na comunidade geológica, como a utilização de províncias estruturais para delimitação das categorias temáticas. Para a quantificação, adaptou a proposta de estratégia de proteção da geodiversidade desenvolvida pela Junta de Andalucía ${ }^{1}$ (2002, apud LIMA, 2008), para o uso no Brasil.

Pereira (2010) realizou um inventário do patrimônio geológico da Chapada Diamantina e desenvolveu uma proposta de método de quantificação. Após realizar um estudo comparativo entre vários métodos, o autor selecionou parâmetros comuns a todos e a adicionou outros, que contemplassem as condições intrínsecas e especificidades dos geossítios de seu trabalho, além do contexto socioeconômico e ambiental onde estavam inseridos. O método de Pereira baseia-se em quatro categorias de valores (intrínseco, científico, turístico e de uso e gestão) a partir dos quais são calculados os usos potenciais para fins científicos, de conservação e a relevância dos locais inventariados.

É importante ressaltar que quando um método é aplicado a uma realidade diversa daquela para a qual foi desenvolvido, os parâmetros de maior valor podem acabar outorgando grande representatividade a determinados locais em detrimento de outros e esta peculiaridade pode gerar alguns resultados não esperados. Por isso a escolha do método é tão importante. Esta escolha se torna razoavelmente difícil, especialmente pelo fato de que há muitas características comuns entre todos estes métodos, especialmente no tocante a alguns dos parâmetros utilizados, como o grau de representatividade de processos geológicos, sua inserção ou não em áreas

1 JUNTA DE ANDALUCÍA. Propuesta de estrategia andaluza para la protección de la Geodiversidad. Consejería de Medio Ambiente. 2002. 105p. 
protegidas, a oferta de infraestrutura para visitação, acessibilidade e grau de deterioração.

No entanto, ela deve ser feita cuidadosamente, já que o processo de inventário de geossítios de um determinado local constitui um dos principais pilares da geoconservação: o conhecimento absoluto e relativo da presença e estado destas manifestações da geodiversidade propicia um ponto de partida para as decisões quanto às estratégias que serão levadas a termo, no intuito de informar, proteger e preservar (GRANDGIRARD², 1999 apud LIMA, 2008).

\subsection{OS MÉTODOS UTILIZADOS PARA A QUANTIFICAÇÃO DO PATRIMÔNIO GEOLÓGICO DE ILHABELA}

Conforme apresentado anteriormente, o valor intrínseco da geodiversidade não é facilmente mensurável, pois não está relacionado a qualquer potencialidade de usos práticos. Quando o senso comum coloca o ser humano acima da natureza e, por conseguinte, decide que esta deve suprir o homem em suas necessidades, o valor intrínseco é mais difícil ainda de ser aferido (BRILHA, 2005). Por isso, é necessário que a valoração da geodiversidade siga parâmetros que determinem o grau de representatividade e importância de um local sem que seu valor intrínseco seja relegado (PEREIRA, 2010).

Callicott (1999) afirma que, já que o ser humano tende a atribuir um valor a si e, por conseguinte, estender a prática a todos os elementos que o circundam, 0 valor intrínseco, que é extremamente subjetivo, acaba por apresentar maior peso nas questões éticas. Também são práticas correntes humanas valorar, descrever e representar a natureza. Humboldt ${ }^{3}$ (2007 apud PEREIRA, 2010) pondera ser impossível posicionar-se frente aos elementos naturais a não ser por duas perspectivas fortemente conjugadas: uma, objetiva, resultado dos sentidos físicos e outra subjetiva, reflexo dos sentimentos desencadeados pela interação dos sentidos com a natureza.

\footnotetext{
${ }^{2}$ GRANDGIRARD, V. L'évaluation des géotopes. Geologica Insubrica, v.4, n.1, 1999, p.59-66.

${ }^{3}$ HUMBOLDT, A. Pinturas da Natureza, uma antologia. Lisboa: Assírio \& Alvim, 2007. 206 p.
} 
Para minimizar os aspectos subjetivos e determinar parâmetros que representem os elementos da geodiversidade aos quais se possa aliar valor qualitativo e quantitativo, vários autores desenvolveram propostas de métodos de quantificação. Ainda assim, quantificar exige emitir um juízo de valor, estimar, ou valorar. Estas ações podem ser muito subjetivas e depender de fatores tão indefiníveis quanto à história pessoal do observador, sua formação acadêmica ou seu senso estético.

Todos os métodos procuram minimizar a interferência pessoal, baseando a valoração em considerações mais objetivas. No entanto, ainda assim não é possível ser totalmente isento de julgamento pessoal neste processo, já que são atribuídos números a cada um dos quesitos de avaliação, e esta escolha passa pelo crivo de experiências/visões pessoais do avaliador.

Para este trabalho foram escolhidos dois métodos: o de Brilha (2005), por sua relevância, e aquele compilado pelo Serviço Geológico do Brasil (CPRM), disponibilizado através do site http:/www.cprm.gov.br/geossit/ e denominado Sistema Geossit, nome com o qual será referido doravante. O Sistema Geossit, ainda em teste e desenvolvimento, alia os métodos de Brilha (2005) e de Ángel Garcia-Cortés \& Luis Carcavilla Urquí (2009).

O método de Brilha foi escolhido porque além de ser um marco de referência para grande parte dos pesquisadores brasileiros e da comunidade científica envolvida com a geoconservação, é aquele no qual a CPRM baseia fortemente seu sistema. O Geossit, por sua vez, foi utilizado para este trabalho justamente por sua relevância nacional. Como o Geossit utiliza em parte o método espanhol, os três métodos serão descritos a seguir.

A comparação de resultados não foi feita no intuito de designar um método "melhor" e sim de descobrir como os parâmetros e quesitos, quando incluídos na quantificação, influem no resultado final.

\subsubsection{O método de Brilha (2005)}

Foi desenvolvido a partir do método de Cendrero Uceda (2000) e como sua elaboração não partiu da necessidade de se trabalhar em um local específico, pode 
ser utilizada em cenários diversos (PEREIRA, 2010). O método pretende facilitar a seriação de um número grande de geossítios e a hierarquia de prioridades de conservação, em escala local a nacional.

Estabelece 22 parâmetros (Tab. 5.2.1a) divididos entre três critérios: valor intrínseco $(A)$, uso potencial $(B)$, e necessidade de proteção do geossítio $(C)$. Cada parâmetro apresenta de 3 a 5 alternativas, que representam cenários possíveis para aquele parâmetro e com valores conjugados. O avaliador seleciona, em cada parâmetro, qual alternativa é a mais próxima da realidade do geossítio a ser quantificado e, com isso, vai atribuindo valores aos parâmetros (Tab.5.2.1b) dos critérios $A, B$ e $C$. Cada critério tem os valores finais obtidos através da soma destes valores.

Ao final da distribuição de valores, verificam-se alguns itens isoladamente, em combinações de condições. Se estas condições não forem satisfeitas, o geossítio é considerado de importância regional ou local e o cálculo de seu valor final é uma média aritmética dos valores finais dos critérios $A, B$ e $C$.

Se, no entanto, os itens $A 1, A 6, A 9, B 1$ forem simultaneamente maiores ou iguais a 3, B2 for maior que 3 e A3 for maior ou igual a 4, o geossítio terá relevância nacional ou internacional. Seu valor final será calculado pela fórmula:

$$
(2 A+B+1,5 C) / 3
$$

O método de Brilha respeita e considera critérios objetivos para definir o valor intrínseco dos geossítios, seu uso potencial e a necessidade de proteção (PEREIRA, 2006), que é exatamente o que se procura em um método de quantificação.

\subsubsection{O método de Ángel Garcia-Cortés \& Luis Carcavilla Urquí (2009)}

Este método teve como finalidade fornecer bases metodológicas para o Inventário Espanhol de Lugares de Interesse Geológico (IELIG) que estava previsto na lei espanhola 42/2007 do Patrimônio Natural e da Biodiversidade. É, segundo Pereira (2010), inovadora, prática, objetiva e apropriada para o uso em escala regional. 
Para a etapa de quantificação, foram levados em consideração os critérios de Cendrero Uceda ${ }^{4}$ (1996, apud GARCIA-CORTÉS \& CARCAVILLA URQUÍ, 2009) que afirmou ser necessário considerar o valor intrínseco, o valor ligado ao potencial de uso e o valor ligado à necessidade de proteção, ao valorarmos um geossítio. Como a quantificação da necessidade de proteção influi nos parâmetros que são comuns aos outros dois valores, porém de modos contrários, trabalhar com os três ao mesmo tempo pode produzir resultados confusos. Assim, o método sugere uma primeira etapa, só com valores intrínsecos e de potencial de uso, divididos em três vertentes de interesse com pesos diferentes: científico, didático e turístico-recreativo. A vulnerabilidade ( $V$ - necessidade de proteção) é quantificada em etapa posterior.

Os parâmetros desta primeira fase estão expostos na tabela 5.2.2a. Cada um deles é desdobrado em 3 alternativas que descrevem a situação do local e que recebem valores de 1, 2 ou 4 pontos ( sendo 0 um valor possível para quando não se alcança sequer a situação mínima). Um exemplo dessas alternativas pode ser visto na tabela 5.2.2b. Os valores finais de cada interesse (lc, ld e It) são dados pela somatória dos valores das alternativas, que foram multiplicadas por seus respectivos pesos. Valores inferiores a 100 determinam geossítios de baixo interesse e que, por isso, são descartados. LIGs de interesse alto alcançam acima de 200 pontos e 0 restante se encaixa na categoria de interesse médio.

Com os valores dos interesses estabelecidos, examina-se a vulnerabilidade do LIG, de acordo com os 10 parâmetros da tabela 5.2.2c, que também receberão alternativas com valores de 0 a 4 cada uma. Alguns parâmetros são similares a alguns da primeira fase, mas os autores justificam esta peculiaridade pelo fato de que influem em sentido contrário e exemplificam: "quanto maior a fragilidade, menor o potencial de uso recreativo ou turístico, porém maior vulnerabilidade e, portanto, maior prioridade de proteção" (GARCIA-CORTÉS \& CARCAVILLA URQUÍ, 2009, p.19).

Os autores também ponderam que os parâmetros utilizados para mensurar a vulnerabilidade de um geossítio podem mudar com o tempo e, portanto, é recomendado que estes cálculos sejam refeitos periodicamente.

\footnotetext{
${ }^{4}$ Cendrero, A. El patrimonio geológico. Ideas para su protección, conservación y utilización. En: El Patrimonio Geológico. Bases para su valoración, protección, conservación yutilización. Madrid: MOPTMA, pp. 17-38, 1996.
} 
Finalmente, para obter a Prioridade de Proteção (PP), soma-se V ao valor de cada sítio e obtém-se uma ordenação de lugares de interesse científico, didático e turístico em função do valor da sua prioridade de proteção. Os cálculos e o significado dos valores obtidos se encontram na tabela 5.2.2d.

\begin{tabular}{|c|c|}
\hline Critério & Parâmetro \\
\hline $\begin{array}{l}\text { A } \\
\text { Valor intrínseco }\end{array}$ & $\begin{array}{l}\text { A1. Abundância/ raridade } \\
\text { A2. Extensão superficial } \\
\text { A3. Grau de conhecimento científico } \\
\text { A4. Utilidade como modelo para ilustração de processos geológicos } \\
\text { A5. Diversidade de elementos de interesse } \\
\text { A6. Local-tipo } \\
\text { A7. Associação com elementos de índole cultural } \\
\text { A8. Associação com outros elementos do meio natural } \\
\text { A9. Estado de conservação }\end{array}$ \\
\hline $\begin{array}{l}\text { B } \\
\text { Uso potencial }\end{array}$ & $\begin{array}{l}\text { B1. Possibilidade de realizar as atividades propostas } \\
\text { B2. Condições de observação } \\
\text { B3. Possibilidade de colheita de objetos geológicos } \\
\text { B4. Acessibilidade } \\
\text { B5. Proximidade a povoações } \\
\text { B6. Número de habitantes } \\
\text { B7. Condições socioeconômicas }\end{array}$ \\
\hline $\begin{array}{l}\text { C } \\
\text { Necessidade de } \\
\text { proteção }\end{array}$ & $\begin{array}{l}\text { C1. Ameaças atuais ou potenciais } \\
\text { C2. Situação atual } \\
\text { C3. Interesse para exploração mineira } \\
\text { C4. Valor dos terrenos } \\
\text { C5. Regime de propriedade } \\
\text { C6. Fragilidade }\end{array}$ \\
\hline
\end{tabular}

Tabela 5.2.1a - Os parâmetros de quantificação no método de Brilha (2005), separados por critérios de valor intrínseco, uso potencial e necessidade de proteção dos geossítios. 


\begin{tabular}{|c|c|c|c|}
\hline Critério & Parâmetro & Alternativas & Valor \\
\hline \multirow{5}{*}{$\begin{array}{l}\text { B } \\
\text { Uso do } \\
\text { geossítio }\end{array}$} & \multirow{5}{*}{$\begin{array}{l}\text { B3 } \\
\text { Possibilidade de } \\
\text { colheita de } \\
\text { objetos } \\
\text { geológicos }\end{array}$} & $\begin{array}{l}\text { É possível colheita de rochas, fósseis e } \\
\text { minerais sem danificar o geossítio. }\end{array}$ & 5 \\
\hline & & $\begin{array}{l}\text { É possível a colheita de rochas ou de } \\
\text { fósseis ou de minerais sem danificar o } \\
\text { geossítio. }\end{array}$ & 4 \\
\hline & & $\begin{array}{l}\text { É possível a colheita de algum tipo de } \\
\text { objeto embora com restrições }\end{array}$ & 3 \\
\hline & & $\begin{array}{l}\text { É possível a colheita de algum tipo de } \\
\text { objeto embora prejudicando o geossítio. }\end{array}$ & 2 \\
\hline & & Não se podem recolher amostras. & 1 \\
\hline
\end{tabular}

Tabela 5.2.1b - Exemplo de como são as alternativas em um parâmetro da quantificação do método de Brilha (2005).

\begin{tabular}{|c|c|c|c|c|}
\hline \multirow[b]{2}{*}{$\begin{array}{l}\text { Caráter do } \\
\text { valor }\end{array}$} & \multirow[b]{2}{*}{ Parâmetro } & \multicolumn{3}{|c|}{ Peso do Interesse } \\
\hline & & $\begin{array}{l}\text { Científico } \\
\text { Ic }\end{array}$ & $\begin{array}{l}\text { Didático } \\
\text { Id }\end{array}$ & $\begin{array}{l}\text { Turístico } \\
\text { It }\end{array}$ \\
\hline \multirow{8}{*}{$\begin{array}{c}\text { Valor } \\
\text { intrínseco }\end{array}$} & 1. Representatividade & 25 & 5 & 0 \\
\hline & $\begin{array}{l}\text { 2.Caráter de localidade tipo ou de } \\
\text { referência }\end{array}$ & 20 & 5 & 0 \\
\hline & $\begin{array}{l}\text { 3. Grau de conhecimento científico } \\
\text { do lugar }\end{array}$ & 15 & 0 & 0 \\
\hline & 4. Estado de conservação & 10 & 5 & 0 \\
\hline & 5. Condições de observação & 5 & 5 & 5 \\
\hline & 6. Raridade & 15 & 5 & 0 \\
\hline & 7. Diversidade geológica & 10 & 10 & 0 \\
\hline & 8. Espetacularidade ou beleza & 0 & 5 & 20 \\
\hline \multirow{3}{*}{$\begin{array}{c}\text { Valor } \\
\text { Intrínseco e } \\
\text { de Uso }\end{array}$} & $\begin{array}{l}\text { 9.Conteúdo de divulgação / Uso } \\
\text { divulgativo }\end{array}$ & 0 & 0 & 15 \\
\hline & 10.Conteúdo didático/ Uso didático & 0 & 20 & 0 \\
\hline & $\begin{array}{l}\text { 11.Possíveis atividades a serem } \\
\text { realizadas }\end{array}$ & 0 & 0 & 5 \\
\hline
\end{tabular}

(continua) 
(continuação)

\begin{tabular}{|c|c|c|c|c|}
\hline \multirow{2}{*}{$\begin{array}{c}\text { Caráter do } \\
\text { valor }\end{array}$} & \multirow[b]{2}{*}{ Parâmetro } & \multicolumn{3}{|c|}{ Peso do Interesse } \\
\hline & & $\begin{array}{c}\text { Científico } \\
\text { Ic }\end{array}$ & $\begin{array}{l}\text { Didático } \\
\text { Id }\end{array}$ & $\begin{array}{c}\text { Turístico } \\
\text { It }\end{array}$ \\
\hline \multirow[t]{3}{*}{ Valor de Uso } & 12.Infraestrutura logística & 0 & 15 & 5 \\
\hline & $\begin{array}{l}\text { 13.Enquadramento } \\
\text { socioeconômico }\end{array}$ & 0 & 0 & 10 \\
\hline & $\begin{array}{l}\text { 14.Associação com outros } \\
\text { elementos do patrimônio natural, } \\
\text { histórico ou etnológico (tradições) }\end{array}$ & 0 & 5 & 5 \\
\hline \multirow{4}{*}{$\begin{array}{l}\text { Valor de Uso } \\
\text { e Proteção }\end{array}$} & 15.Densidade populacional & 0 & 5 & 5 \\
\hline & 16.Acessibilidade & 0 & 15 & 10 \\
\hline & 17.Fragilidade intrínseca & 0 & 0 & 15 \\
\hline & $\begin{array}{l}\text { 18.Proximidade com zonas } \\
\text { recreativas }\end{array}$ & 0 & 0 & 5 \\
\hline
\end{tabular}

Tabela 5.2.2a - Os parâmetros e seus pesos correspondentes no método de Garcia-Cortés \& Carcavilla Urqui (2009).

\begin{tabular}{|c|c|r|c|}
\hline Valor & Parâmetro & Alternativas & Valor \\
\hline Valor & Raridade & Um dos poucos exemplos conhecidos a & 1 \\
& & nível regional & \\
\cline { 3 - 4 } & & Único exemplo conhecido a nível & 2 \\
& & regional & 4 \\
& & Único exemplo conhecido a nível \\
& & nacional (ou internacional) & \\
\cline { 3 - 4 } & & & \\
\end{tabular}

Tabela 5.2.2b - Exemplo de alternativas e valores numéricos possíveis para o parâmetro "Raridade" no critério de valor intrínseco de um LIG no método de Garcia-Cortés \& Carcavilla Urqui (2009). 


\begin{tabular}{|c|c|c|}
\hline $\begin{array}{l}\text { Parâmetros de quantificação } \\
\text { de vulnerabilidade (V) }\end{array}$ & Descrição & Peso \\
\hline Vulnerabilidade antrópica & Informa sobre a existência de ameaças antrópicas & 15 \\
\hline $\begin{array}{l}\text { Interesse para a exploração } \\
\text { mineira }\end{array}$ & $\begin{array}{l}\text { Vulnerabilidade devido ao afloramento de minérios } \\
\text { ou rochas de interesse comercial }\end{array}$ & 15 \\
\hline Vulnerabilidade natural & $\begin{array}{l}\text { Existência de processos ativos da natureza que } \\
\text { ameacem a integridade do local }\end{array}$ & 15 \\
\hline Fragilidade intrínseca & $\begin{array}{l}\text { Vulnerabilidade intrínseca por suas dimensões ou } \\
\text { por sua natureza }\end{array}$ & 10 \\
\hline Regime de proteção & $\begin{array}{l}\text { Localização do geossítio dentro ou fora de áreas } \\
\text { protegidas }\end{array}$ & 10 \\
\hline Proteção física ou indireta & Relativo a dificuldades físicas de acesso ao local & 10 \\
\hline Acessibilidade & $\begin{array}{l}\text { Relacionado à necessidade de proteção devido à } \\
\text { facilidade maior de sofrer vandalismo }\end{array}$ & 10 \\
\hline $\begin{array}{l}\text { Regime de propriedade do } \\
\text { solo }\end{array}$ & $\begin{array}{l}\text { Se privado, público de acesso livre ou público de } \\
\text { acesso restrito }\end{array}$ & 5 \\
\hline Densidade populacional & $\begin{array}{l}\text { Relacionado com a necessidade de proteção por } \\
\text { aumentar a possibilidade de atos de vandalismo }\end{array}$ & 5 \\
\hline $\begin{array}{l}\text { Proximidade de zonas } \\
\text { recreativas }\end{array}$ & $\begin{array}{l}\text { Relacionado com a necessidade de proteção por } \\
\text { aumentar a possibilidade de atos de vandalismo }\end{array}$ & 5 \\
\hline
\end{tabular}

Tabela 5.2.2c - Os parâmetros para a quantificação da vulnerabilidade de um geossítio e seus respectivos pesos, no método de Garcia-Cortés \& Carcavilla Urqui (2009).

\begin{tabular}{|c|c|c|}
\hline Cálculo da Prioridade de Proteção & \multicolumn{2}{|c|}{ Significado do resultado obtido } \\
\hline$P P c=I c+V$ & Acima de 500 & $\begin{array}{c}\text { Necessita de } \\
\text { proteção urgente }\end{array}$ \\
\hline$P P d=I d+V$ & Entre 500 e 201 & $\begin{array}{c}\text { Necessita de } \\
\text { proteção em médio } \\
\text { prazo }\end{array}$ \\
\hline $\mathrm{PP}=[(\mathrm{Ic}+\mathrm{Id}+\mathrm{It}) / 3]+\mathrm{V}$ & Abaixo de 201 & $\begin{array}{l}\text { Não necessita de } \\
\text { figura específica de } \\
\text { proteção }\end{array}$ \\
\hline
\end{tabular}

Tabela 5.2.2d - Cálculo da prioridade de proteção de um geossítio em sua vertente científica (PPc), didática (PPd), turística (PPt) e global (PP) e o significado dos números obtidos, no método de Garcia-Cortés \& Carcavilla Urqui (2009). 


\subsubsection{Geossit - o sistema do Serviço Geológico do Brasil (CPRM)}

A plataforma do Sistema Geossit é uma iniciativa brasileira para registrar e quantificar o patrimônio geológico do país. Consiste em várias fichas online para a descrição do geossítio, com quesitos como a localização (acesso, pontos de referência, coordenadas geográficas), o enquadramento geológico (contexto, terreno, unidade estratigráfica, etc.), a caracterização geológica (tipo de rocha, ambiente, estruturas, etc.), feições de relevo, tipo de interesse (paleontológico, turístico, didático, etc.), se está localizado em uma Unidade de Conservação e qual quantificação e dados do responsável pelo cadastro.

A quantificação é feita através de planilhas eletrônicas que compilam os dados digitados e calculam automaticamente o resultado final dos valores de vulnerabilidade, características intrínsecas, uso potencial e necessidade de proteção. A partir desses valores, as planilhas indicam qual o tipo de relevância (regional, nacional ou internacional), os valores didático, científico e turístico e a recomendação de medidas de proteção em curto, médio ou longo prazo.

A quantificação é iniciada por uma planilha de valoração da vulnerabilidade, cujos parâmetros e pesos relativos foram extraídos do método de Garcia-Cortés \& Carcavilla Urqui (2009) (Tab.5.2.3a). As alternativas fornecidas para a valoração de cada parâmetro são essencialmente as mesmas, exceto onde foi necessária a alguma adaptação, como a modificação de algumas medidas de espaço. Um exemplo é o parâmetro "Proximidade de áreas recreativas", onde se lê "lugar situado a menos de $500 \mathrm{~m}$ de uma área recreativa" no original espanhol e "local situado a menos de $1 \mathrm{~km}$ de uma área recreativa (camping, praia, etc.)" no sistema da CPRM.

A segunda aba da planilha revela a quantificação das características intrínsecas do geossítio. Nesse quesito, foram mantidos os nove parâmetros do método de Brilha (2005) e adicionado um décimo parâmetro (A10) com o nome de "Utilização da imagem na divulgação turística" e que, na verdade, corresponde ao parâmetro "Espetacularidade ou beleza" no método de Garcia-Cortés \& Carcavilla Urqui (2009) (Tab 5.2.3b). Este parâmetro do Geossit, A10, conta com seis alternativas (valores de zero a 5), contra quatro possibilidades no método espanhol (valores 0, 1, 2 e 4). 


\begin{tabular}{|l|r|}
\hline \multicolumn{1}{|c|}{ VULNERABILIDADE } & Peso \\
\hline Ameaças antrópicas & 15 \\
\hline Interesse para exploração mineral & 15 \\
\hline Ameaças naturais & 15 \\
\hline Fragilidade intrínseca & 10 \\
\hline Regime de proteção do local & 10 \\
\hline Proteção física ou indireta & 10 \\
\hline Acessibilidade & 10 \\
\hline Regime de propriedade do local & 5 \\
\hline Densidade de população (agressão potencial) & 5 \\
\hline Proximidades de áreas recreativas (agressão potencial) & 5 \\
\hline
\end{tabular}

Tabela 5.2.3a - Parâmetros para quantificação da vulnerabilidade no Geossit (CPRM)

Infere-se que este parâmetro adicional tenha sido incluído neste momento da quantificação por ser o país um local onde proliferam exemplos de localidades que são verdadeiros "cartões postais", mundialmente considerados por sua beleza. Esta é uma característica intrínseca ao local, ainda que a mensuração da beleza seja um fator subjetivo.

Como já foi dito, as alternativas de cada parâmetro foram adaptadas à realidade brasileira, admitindo unidades de medida de espaço mais coerentes com as dimensões do país (A2-Geossit, por exemplo, utiliza hectares, enquanto A2-Brilha utiliza metros quadrados) e referências nacionais (A3-Geossit reconhece a SIGEP como tendo o mesmo status de tese de doutorado ou artigo de revista com corpo editorial). O valor final das características intrínsecas é fornecido por média aritmética dos valores atribuídos a cada um dos parâmetros, diferentemente da soma simples utilizada no método de Brilha (2005).

Analogamente aos critérios da seção A (Características Intrínsecas), os parâmetros de Uso Potencial (B) e Necessidade de Proteção (C) também foram baseados no método de Brilha, com alternativas para valoração adaptadas à realidade brasileira, quando necessário (B7-Geossit, por exemplo, utiliza o IDH como parâmetro de desenvolvimento e B7-Brilha considera os níveis de renda per capita, educação e desemprego). 
Foram adicionados os parâmetros "B8. Utilização didática" e "B9. Conteúdo divulgativo" em Uso Potencial e "C7. Proximidade de áreas recreativas" em Necessidade de Proteção, todos advindos do método de Garcia-Cortés \& Carcavilla Urqui (2009).

No que concerne às alternativas destes parâmetros, B7-Geossit e B8-Geossit apresentam duas possibilidades de valores a mais que as dos parâmetros espanhóis, porém o conteúdo praticamente não sofreu alteração.

\begin{tabular}{|c|c|}
\hline & Critérios para quantificação dos geossítios \\
\hline $\begin{array}{l}\text { A } \\
\text { Características } \\
\text { Intrínsecas }\end{array}$ & $\begin{array}{l}\text { A1. Abundância/Raridade } \\
\text { A2. Extensão } \\
\text { A3. Grau de conhecimento científico } \\
\text { A4. Utilidade como modelo para ilustração de processos geológicos } \\
\text { A5. Diversidade de elementos de interesse pelo conteúdo } \\
\text { A6. Local-tipo } \\
\text { A7. Associação com elementos culturais } \\
\text { A8. Associação com elementos naturais } \\
\text { A9. Estado de conservação } \\
\text { A10. Utilização da imagem na divulgação turística }\end{array}$ \\
\hline $\begin{array}{l}\text { B } \\
\text { Uso Potencial }\end{array}$ & $\begin{array}{l}\text { B1. Possibilidade de realizar as atividades propostas } \\
\text { B2. Condições de Observação } \\
\text { B3. Possibilidades de coleta de materiais } \\
\text { B4. Acessibilidade } \\
\text { B5. Proximidade de povoação } \\
\text { B6. População a ser beneficiada com a utilização/divulgação do geossítio } \\
\text { B7. Condições socioeconômicas } \\
\text { B8. Utilização didática } \\
\text { B9. Conteúdo divulgativo }\end{array}$ \\
\hline $\begin{array}{l}\text { C } \\
\text { Necessidade de } \\
\text { Proteção }\end{array}$ & $\begin{array}{l}\text { C1. Ameaças atuais ou potenciais } \\
\text { C2. Situação atual } \\
\text { C3. Interesse para exploração mineral } \\
\text { C4. Valor dos terrenos } \\
\text { C5. Regime de propriedade } \\
\text { C6. Fragilidade (perante a ação humana) } \\
\text { C7. Proximidade de áreas recreativas }\end{array}$ \\
\hline
\end{tabular}


(continuação)

Critérios de relevância dos geossítios:

a) Internacional: A1, A3, A9, B1 e B2 simultaneamente maiores ou iguais a 4; A6, igual a 5.

b) Nacional: A1, A6, A9, B1 e B2 simultaneamente maiores ou iguais a 3; A3 maior ou igual a 4.

$$
\text { Quantificação específica }=(2 A+B+1.5 C) / 3
$$

c) Regional: Não obedecem aos critérios referidos acima.

$$
\text { Quantificação geral }=(A+B+C) / 3
$$

Tabela 5.2.3b - Parâmetros para quantificação das características intrínsecas de um geossítio no Geossit (CPRM).

As modificações feitas para resultar nas alternativas de C7-Geossit colocam as áreas recreativas mais próximas, variando de $500 \mathrm{~m}$ a $2500 \mathrm{~m}$, enquanto o modelo espanhol apresenta somente três possibilidades: $500 \mathrm{~m}, 2000 \mathrm{~m}$ e $5000 \mathrm{~m}$.

Para obter os resultados finais das seções $B$ e $C$ são feitas médias aritméticas dos valores dos parâmetros de cada uma delas separadamente. Para saber se um geossítio tem relevância regional, nacional ou internacional, consultam-se as condições que se encontram ao final da tabela 5.2.3b e procede-se ao cálculo indicado em cada um dos casos.

O sistema ainda calcula os interesses científico, didático e turístico de cada geossítio, utilizando-se do mesmo método de valoração de Garcia-Cortés \& Carcavilla Urqui (2009), porém com dois parâmetros sutilmente distintos e com atribuição de pesos às vezes diferentes. Na tabela $5.2 .3 \mathrm{c}$ podem ser vistos os parâmetros utilizados para este cálculo no Sistema Geossit e na tabela 5.2.1a, aqueles empregados no método espanhol. O item A7-Geossit corresponde em parte ao item espanhol "14. Associação com outros elementos do patrimônio natural, histórico ou etnológico (tradições)", pois engloba somente as manifestações arqueológicas e culturais de outros tipos. Também o item B5-Geossit, que destaca a proximidade de oferta hoteleira, corresponde parcialmente ao item "12. Infraestrutura logística" espanhol, que prioriza o número de pessoas beneficiadas por esta oferta a 5 e a $25 \mathrm{~km}$ de proximidade.

A prioridade de proteção é dada somando-se o valor obtido no cálculo da vulnerabilidade a cada um dos interesses, exatamente como no método de Garcia- 
Cortés \& Carcavilla Urqui (2009). Valores entre 900 e 1000 denotam necessidade de proteção urgente; entre 700 e 900, em curto prazo; de 400 a 700, em médio prazo e de 0 a 400 , em longo prazo.

\begin{tabular}{|c|c|c|c|}
\hline Parâmetros & $\begin{array}{c}\text { Peso } \\
\text { Científico }\end{array}$ & $\begin{array}{c}\text { Peso } \\
\text { Didático }\end{array}$ & $\begin{array}{c}\text { Peso } \\
\text { Turístico }\end{array}$ \\
\hline A1. Abundância / raridade & 10 & 5 & 0 \\
\hline A3. Grau de conhecimento científico & 15 & 10 & 0 \\
\hline $\begin{array}{l}\text { A4. Utilidade como modelo para ilustração de } \\
\text { processos geológicos }\end{array}$ & 20 & 5 & 0 \\
\hline $\begin{array}{l}\text { A5. Diversidade de elementos de interesse pelo } \\
\text { conteúdo }\end{array}$ & 10 & 10 & 0 \\
\hline A6. Local - tipo & 20 & 5 & 0 \\
\hline A7. Associação com elementos culturais & 0 & 5 & 5 \\
\hline A9. Estado de conservação & 10 & 5 & 5 \\
\hline A10. Utilização da imagem na divulgação turística & 0 & 5 & 15 \\
\hline $\begin{array}{l}\text { B1. Possibilidades de realizar as atividades } \\
\text { propostas }\end{array}$ & 0 & 5 & 5 \\
\hline B2. Condições de observação & 5 & 5 & 5 \\
\hline B4. Acessibilidade & 5 & 10 & 10 \\
\hline B5. Proximidade de povoação & 0 & 5 & 5 \\
\hline $\begin{array}{l}\text { B6. População a ser beneficiada com a } \\
\text { utilização/divulgação do geossítio }\end{array}$ & 0 & 5 & 5 \\
\hline B7. Condições socioeconômicas & 0 & 0 & 10 \\
\hline B8. Utilização didática & 0 & 20 & 0 \\
\hline B9. Conteúdo divulgativo & 0 & 0 & 15 \\
\hline C6. Fragilidade (perante ação humana) & 5 & 0 & 15 \\
\hline C7. Proximidade de áreas recreativas & 0 & 0 & 5 \\
\hline
\end{tabular}

Tabela 5.2.3c - Os parâmetros e seus pesos relativos para cálculo de Interesses científico, didático e turístico no sistema da plataforma Geossit (CPRM). 


\subsection{RESULTADOS DA QUANTIFICAÇÃO}

Para proceder à quantificação dos geossítios usando os dois métodos foi necessário fazer algumas adaptações e solucionar impasses, especialmente no tocante às alternativas oferecidas para alguns dos parâmetros, que não contemplaram o contexto de llhabela.

Por exemplo, alguns geossítios estão em locais públicos, porém o acesso a eles passa necessariamente por propriedade privada. Outro exemplo é o parâmetro "proximidade a áreas recreativas" considerar, entre estas áreas, as praias. Alguns geossítios estão em praias que não têm o caráter "recreativo" de uma praia que recebe visitação em massa.

Entende-se que isto tenha acontecido porque: 1) o método de Brilha logicamente baseou-se principalmente na realidade europeia; e 2) o Geossit ainda é um sistema novo, que combina dois modelos europeus e que, por ser recente, ainda não foi extensivamente aplicado às várias realidades brasileiras, o que talvez tivesse motivado maiores adaptações. Por hora, serão expostos somente os resultados finais dos métodos utilizados. Os problemas, adaptações, soluções e discussões deste processo serão expostos no cap.7, Discussões e Conclusões.

\subsubsection{Método de Brilha (2005)}

Segundo este método, a prioridade de intervenção deve ser feita nos geossítios constantes deste estudo na seguinte ordem:

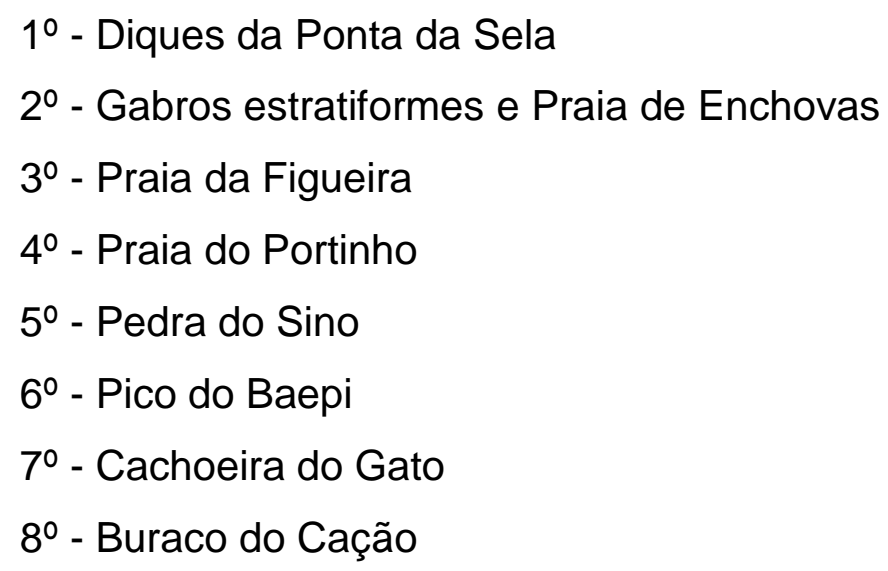


A tabela 5.3.1a apresenta os resultados finais dos critérios $A, B$ e $C$, o valor final de cada geossítio e sua posição na prioridade de intervenção, obtidos através do cálculo de quantificação do método de Brilha. Os valores atribuídos a cada um dos parâmetros foram expostos na tabela 5.3.1b.

\begin{tabular}{|l|c|c|c|c|c|}
\hline \multicolumn{1}{|c|}{ Geossítio } & A & B & C & Valor final & Posição \\
\hline 1. Pedra do Sino & 19 & 31 & 20 & 23,33 & $5^{\circ}$ \\
\hline 2. Pico do Baepi & 21 & 26 & 21 & 22,67 & $6^{\circ}$ \\
\hline 3. Cachoeira do Gato & 21 & 26 & 20 & 22,33 & $7^{\circ}$ \\
\hline 4. Praia da Figueira & 29 & 25 & 19 & 24,33 & $3^{\circ}$ \\
\hline 5. Praia de Enchovas & 28 & 25 & 21 & 24,67 & $2^{\circ}$ \\
\hline 6. Buraco do Cação & 21 & 24 & 20 & 21,67 & $8^{\circ}$ \\
\hline 7. Diques da Ponta da Sela & 24 & 29 & 23 & 25,33 & $1^{\circ}$ \\
\hline 8. Gabros estratiformes & 24 & 29 & 21 & 24,67 & $2^{\circ}$ \\
\hline 9. Praia do Portinho & 24 & 30 & 18 & 24 & $4^{\circ}$ \\
\hline
\end{tabular}

Tabela 5.3.1a - Resultados finais dos critérios A, B e C e posição no ranking final dos geossítios pela quantificação do método de Brilha (2005).

\begin{tabular}{|l|c|c|c|c|c|c|c|c|c|c|}
\hline $\begin{array}{l}\text { CARACTERÍSTICAS } \\
\text { INTRÍNSECAS }\end{array}$ & & $\mathbf{1}$ & $\mathbf{2}$ & $\mathbf{3}$ & $\mathbf{4}$ & $\mathbf{5}$ & $\mathbf{6}$ & $\mathbf{7}$ & $\mathbf{8}$ & $\mathbf{9}$ \\
\hline Abundância/raridade & $\mathrm{A} 1$ & 5 & 4 & 5 & 4 & 5 & 4 & 3 & 4 & 4 \\
\hline Extensão & $\mathrm{A} 2$ & 1 & 1 & 1 & 2 & 2 & 1 & 2 & 2 & 1 \\
\hline Grau de conhecimento científico & $\mathrm{A} 3$ & 1 & 1 & 1 & 2 & 2 & 1 & 2 & 1 & 2 \\
\hline $\begin{array}{l}\text { Utilidade como modelo para } \\
\text { ilustração de processos geológicos }\end{array}$ & $\mathrm{A} 4$ & 1 & 3 & 1 & 3 & 3 & 3 & 5 & 5 & 5 \\
\hline $\begin{array}{l}\text { Diversidade de elementos de } \\
\text { interesse presentes }\end{array}$ & $\mathrm{A} 5$ & 3 & 2 & 3 & 3 & 4 & 2 & 2 & 2 & 3 \\
\hline Local-tipo & $\mathrm{A} 6$ & 1 & 1 & 1 & 1 & 1 & 1 & 1 & 1 & 1 \\
\hline $\begin{array}{l}\text { Associação com elementos de } \\
\text { índole cultural }\end{array}$ & $\mathrm{A} 7$ & 2 & 1 & 1 & 4 & 1 & 1 & 1 & 1 & 1 \\
\hline $\begin{array}{l}\text { Associação com outros elementos } \\
\text { do meio natural }\end{array}$ & $\mathrm{A} 8$ & 1 & 3 & 3 & 5 & 5 & 3 & 3 & 3 & 3 \\
\hline Estado de conservação & $\mathrm{A} 9$ & 4 & 5 & 5 & 5 & 5 & 5 & 5 & 5 & 4 \\
\hline & Soma & $\mathbf{1 9}$ & $\mathbf{2 1}$ & $\mathbf{2 1}$ & $\mathbf{2 9}$ & $\mathbf{2 8}$ & $\mathbf{2 1}$ & $\mathbf{2 5}$ & $\mathbf{2 4}$ & $\mathbf{2 4}$
\end{tabular}

(continua) 
(continuação)

\begin{tabular}{|l|c|c|c|c|c|c|c|c|c|c|}
\hline USO DO GEOSSíTIO & & 1 & 2 & 3 & 4 & 5 & 6 & 7 & 8 & 9 \\
\hline $\begin{array}{l}\text { Possibilidades de realizar } \\
\text { atividades }\end{array}$ & $\mathrm{B} 1$ & 5 & 5 & 5 & 5 & 5 & 3 & 5 & 5 & 5 \\
\hline Condições de observação & $\mathrm{B} 2$ & 5 & 5 & 5 & 5 & 5 & 5 & 5 & 5 & 5 \\
\hline $\begin{array}{l}\text { Possibilidades de coleta de objetos } \\
\text { geológicos }\end{array}$ & $\mathrm{B} 3$ & 4 & 4 & 4 & 4 & 4 & 4 & 4 & 4 & 3 \\
\hline Acessibilidade & & & & & & & & \\
\hline Proximidade a povoações & B5 & 4 & 1 & 1 & 1 & 1 & 1 & 2 & 2 & 4 \\
\hline Número de habitantes & B6 & 3 & 3 & 3 & 3 & 3 & 3 & 3 & 3 & 3 \\
\hline Condições socioeconômicas & B7 & 5 & 5 & 5 & 5 & 5 & 5 & 5 & 5 & 5 \\
\hline
\end{tabular}

Tabela 5.3.1b - Valores atribuídos a cada um dos parâmetros para a quantificação dos geossítios pelo método de Brilha (2005). Nesta tabela, os geossítios são: 1-Pedra do Sino, 2-Pico do Baepi, 3Cachoeira do Gato, 4 - Praia da Figueira, 5 - Praia de Enchovas, 6 - Buraco do Cação, 7 - Diques da Ponta da Sela, 8 - Gabros estratiformes e 9 - Praia do Portinho.

\subsubsection{Geossit}

Segundo a quantificação por este método, mais complexo que o anterior, (pois aplica pesos diferentes aos parâmetros, segundo o tipo de interesse e calcula a vulnerabilidade separadamente, para depois incluí-la ao calculo final), a prioridade de proteção é a que segue:

\section{1ํ Pedra do Sino}

2ำ Praia do Portinho

3 o Diques da Ponta da Sela 


\author{
4ํㅡㅁabros estratiformes \\ 5ำ Praia da Figueira \\ 6ํㅡㄴ Cachoeira do Gato \\ $7^{\circ}$ Praia de Enchovas \\ 8 Pico do Baepi \\ 9ํㅗㄱoco do Cação
}

A tabela 5.3.2a apresenta os valores dos interesses científico, didático, turístico e global, da vulnerabilidade, da prioridade de proteção de cada geossítio e seu lugar na seriação. Nas tabelas posteriores se encontram os valores atribuídos aos parâmetros dos critérios A, B e C (Tab.5.3.2b/c/d), os cálculos de interesses (Tab. 5.3.2e/f/g) e os cálculos do interesse global (Tab 5.3.2h).

\begin{tabular}{|l|c|c|c|c|c|c|c|}
\hline \multicolumn{1}{|c|}{ Geossítio } & Ic & Id & It & Ig & V & PP & Posição \\
\hline 1. Pedra do Sino & 255 & 330 & 350 & 311,7 & 220 & 531,7 & $1^{\circ}$ \\
\hline 2. Pico do Baepi & 255 & 205 & 265 & 241,7 & 60 & 301,7 & $8^{\circ}$ \\
\hline 3. Cachoeira do Gato & 245 & 205 & 230 & 226,7 & 85 & 311,7 & $6^{\circ}$ \\
\hline 4. Praia da Figueira & 280 & 240 & 250 & 256,7 & 60 & 316,7 & $5^{\circ}$ \\
\hline 5. Praia de Enchovas & 290 & 225 & 235 & 250 & 60 & 310 & $7^{\circ}$ \\
\hline 6. Buraco do Cação & 255 & 190 & 230 & 225 & 60 & 285 & $9^{\circ}$ \\
\hline $\begin{array}{l}\text { 7. Diques da Ponta da } \\
\text { Sela }\end{array}$ & 285 & 225 & 245 & 251,7 & 105 & 356,7 & $3^{\circ}$ \\
\hline 8. Gabros estratiformes & 300 & 225 & 245 & 256,7 & 95 & 351,7 & $4^{\circ}$ \\
\hline 9. Praia do Portinho & 300 & 270 & 245 & 271,7 & 160 & 431,7 & $2^{\circ}$ \\
\hline
\end{tabular}

Tabela 5.3.2a - Valores dos interesses científico (Ic), didático (Id), turístico (It) global (Ig), vulnerabilidade $(\mathrm{V})$ e valor final da prioridade de proteção $(\mathrm{PP})$ de cada geossítio, bem como sua posição na lista de prioridade de intervenção, calculados através do Geossit (CPRM). 


\begin{tabular}{|l|c|c|c|c|c|c|c|c|c|c|}
\hline VULNERABILIDADE & Peso & $\mathbf{1}$ & $\mathbf{2}$ & $\mathbf{3}$ & $\mathbf{4}$ & $\mathbf{5}$ & $\mathbf{6}$ & $\mathbf{7}$ & $\mathbf{8}$ & $\mathbf{9}$ \\
\hline Ameaças antrópicas & 15 & 1 & 0 & 0 & 0 & 0 & 0 & 1 & 1 & 1 \\
\hline Interesse para exploração mineral & 15 & 0 & 0 & 0 & 0 & 0 & 0 & 0 & 0 & 0 \\
\hline Ameaças naturais & 15 & 1 & 1 & 1 & 1 & 1 & 1 & 1 & 1 & 1 \\
\hline Fragilidade intrínseca & 10 & 3 & 1 & 1 & 1 & 1 & 1 & 1 & 1 & 3 \\
\hline Regime de proteção do local & 10 & 1 & 1 & 1 & 1 & 1 & 1 & 1 & 1 & 1 \\
\hline Proteção física ou indireta & 10 & 5 & 0 & 0 & 0 & 0 & 0 & 1 & 0 & 1 \\
\hline Acessibilidade & 10 & 5 & 0 & 0 & 0 & 0 & 0 & 1 & 1 & 3 \\
\hline Regime de propriedade do local & 5 & 2 & 2 & 2 & 2 & 2 & 2 & 4 & 4 & 2 \\
\hline $\begin{array}{l}\text { Densidade de população (agressão } \\
\text { potencial) }\end{array}$ & 5 & 3 & 3 & 3 & 3 & 3 & 3 & 3 & 3 & 3 \\
\hline $\begin{array}{l}\text { Proximidades de áreas recreativas } \\
\text { (agressão potencial) }\end{array}$ & 5 & 5 & 0 & 5 & 0 & 0 & 0 & 0 & 0 & 5 \\
\cline { 1 - 9 } & Soma & 220 & 60 & 85 & 60 & 60 & 60 & 105 & 95 & 160 \\
\cline { 2 - 10 }
\end{tabular}

Tabela 5.3.2b - Cálculo da vulnerabilidade (V) dos geossítios de llhabela no Geossit (CPRM). Nesta tabela, os geossítios são: 1-Pedra do Sino, 2-Pico do Baepi, 3-Cachoeira do Gato, 4 - Praia da Figueira, 5 - Praia de Enchovas, 6 - Buraco do Cação, 7 - Diques da Ponta da Sela, 8 - Gabros estratiformes e 9 - Praia do Portinho.

\begin{tabular}{|l|c|c|c|c|c|c|c|c|c|c|}
\hline CARACTERÍSTICAS INTRÍNSECAS & A & $\mathbf{1}$ & $\mathbf{2}$ & $\mathbf{3}$ & $\mathbf{4}$ & $\mathbf{5}$ & $\mathbf{6}$ & $\mathbf{7}$ & $\mathbf{8}$ & $\mathbf{9}$ \\
\hline Abundância/raridade & $\mathrm{A} 1$ & 5 & 5 & 5 & 5 & 5 & 5 & 4 & 5 & 5 \\
\hline Extensão & $\mathrm{A} 2$ & 1 & 1 & 1 & 2 & 2 & 1 & 2 & 2 & 1 \\
\hline Grau de conhecimento científico & $\mathrm{A} 3$ & 0 & 0 & 0 & 1 & 1 & 0 & 1 & 0 & 1 \\
\hline $\begin{array}{l}\text { Utilidade como modelo para ilustração } \\
\text { de processos geológicos }\end{array}$ & $\mathrm{A} 4$ & 2 & 3 & 2 & 3 & 3 & 3 & 4 & 5 & 4 \\
\hline $\begin{array}{l}\text { Diversidade de elementos de interesse } \\
\text { pelo conteúdo }\end{array}$ & A5 & 3 & 2 & 3 & 3 & 4 & 2 & 2 & 2 & 3 \\
\hline Local-tipo & A6 & 1 & 1 & 1 & 1 & 1 & 1 & 1 & 1 & 1 \\
\hline Associação com elementos culturais & A7 & 3 & 0 & 0 & 5 & 0 & 0 & 0 & 0 & 0 \\
\hline Associação com elementos naturais & A8 & 0 & 3 & 3 & 4 & 4 & 3 & 3 & 3 & 3 \\
\hline Estado de conservação & A9 & 4 & 5 & 5 & 5 & 5 & 5 & 5 & 5 & 4 \\
\hline $\begin{array}{l}\text { Utilização da imagem na divulgação } \\
\text { turística }\end{array}$ & A10 & 2 & 2 & 1 & 1 & 1 & 0 & 0 & 0 & 1 \\
\hline
\end{tabular}

Tabela 5.3.2c - Valores atribuídos aos parâmetros e cálculo final de A (características intrínsecas) dos geossítios no Geossit (CPRM). Nesta tabela, os geossítios são: 1-Pedra do Sino, 2-Pico do Baepi, 3-Cachoeira do Gato, 4 - Praia da Figueira, 5 - Praia de Enchovas, 6 - Buraco do Cação, 7 Diques da Ponta da Sela, 8 - Gabros estratiformes e 9 - Praia do Portinho. 


\begin{tabular}{|l|c|c|c|c|c|c|c|c|c|c|}
\hline USO POTENCIAL & B & $\mathbf{1}$ & $\mathbf{2}$ & $\mathbf{3}$ & $\mathbf{4}$ & $\mathbf{5}$ & $\mathbf{6}$ & $\mathbf{7}$ & $\mathbf{8}$ & $\mathbf{9}$ \\
\hline $\begin{array}{l}\text { Possibilidades de realizar as } \\
\text { atividades propostas }\end{array}$ & B1 & 4 & 4 & 4 & 4 & 4 & 3 & 4 & 4 & 4 \\
\hline Condições de observação & B2 & 5 & 5 & 5 & 5 & 5 & 5 & 5 & 5 & 5 \\
\hline Possibilidades de coleta de materiais & B3 & 4 & 4 & 4 & 4 & 4 & 4 & 4 & 4 & 3 \\
\hline Acessibilidade & B4 & 5 & 1 & 1 & 1 & 1 & 1 & 2 & 2 & 5 \\
\hline Proximidade de povoação & B5 & 5 & 3 & 3 & 2 & 2 & 3 & 5 & 5 & 5 \\
\hline $\begin{array}{l}\text { População a ser beneficiada com a } \\
\text { utilização/divulgação do geossítio }\end{array}$ & B6 & 3 & 3 & 3 & 3 & 3 & 3 & 3 & 3 & 3 \\
\hline Condições socioeconômicas & B7 & 1 & 1 & 1 & 1 & 1 & 1 & 1 & 1 & 1 \\
\hline Utilização didática & B8 & 4 & 1 & 1 & 1 & 1 & 1 & 1 & 1 & 1 \\
\hline Conteúdo divulgativo & B9 & 4 & 1 & 1 & 1 & 1 & 1 & 1 & 1 & 1 \\
\hline
\end{tabular}

Tabela 5.3.2d - Valores atribuídos aos parâmetros e cálculo final de B (uso potencial) dos geossítios no Geossit (CPRM). Nesta tabela, os geossítios são: 1-Pedra do Sino, 2-Pico do Baepi, 3-Cachoeira do Gato, 4 - Praia da Figueira, 5 - Praia de Enchovas, 6 - Buraco do Cação, 7 - Diques da Ponta da Sela, 8 - Gabros estratiformes e 9 - Praia do Portinho.

\begin{tabular}{|l|c|c|c|c|c|c|c|c|c|c|}
\hline NECESSIDADE DE PROTEÇÃO & $\mathbf{C}$ & $\mathbf{1}$ & $\mathbf{2}$ & $\mathbf{3}$ & $\mathbf{4}$ & $\mathbf{5}$ & $\mathbf{6}$ & $\mathbf{7}$ & $\mathbf{8}$ & $\mathbf{9}$ \\
\hline Ameaças atuais ou potenciais & $\mathrm{C} 1$ & 3 & 5 & 5 & 5 & 4 & 5 & 4 & 3 & 3 \\
\hline Situação atual & $\mathrm{C} 2$ & 1 & 5 & 5 & 5 & 1 & 5 & 1 & 1 & 1 \\
\hline Interesse para exploração mineral & $\mathrm{C} 3$ & 5 & 5 & 5 & 5 & 5 & 5 & 5 & 5 & 5 \\
\hline Valor dos terrenos & $\mathrm{C} 4$ & 1 & 0 & 0 & 0 & 0 & 0 & 1 & 1 & 1 \\
\hline Regime de propriedade & $\mathrm{C} 5$ & 3 & 5 & 5 & 5 & 5 & 5 & 5 & 5 & 3 \\
\hline Fragilidade (Perante ação humana) & C6 & 5 & 5 & 5 & 5 & 5 & 5 & 5 & 5 & 3 \\
\hline Proximidade de áreas recreativas & C7 & 1 & 5 & 1 & 1 & 3 & 5 & 3 & 3 & 1 \\
\hline
\end{tabular}

Tabela 5.3.2d - Valores atribuídos aos parâmetros e cálculo final de $C$ (necessidade de proteção) dos geossítios no Geossit (CPRM). Nesta tabela, os geossítios são: 1-Pedra do Sino, 2-Pico do Baepi, 3Cachoeira do Gato, 4 - Praia da Figueira, 5 - Praia de Enchovas, 6 - Buraco do Cação, 7 - Diques da Ponta da Sela, 8 - Gabros estratiformes e 9 - Praia do Portinho. 


\begin{tabular}{|c|c|c|c|c|c|c|c|c|c|c|}
\hline $\begin{array}{c}\text { Int. } \\
\text { Científico }\end{array}$ & Peso & $\mathbf{1}$ & $\mathbf{2}$ & $\mathbf{3}$ & $\mathbf{4}$ & $\mathbf{5}$ & $\mathbf{6}$ & $\mathbf{7}$ & $\mathbf{8}$ & $\mathbf{9}$ \\
\hline A1 & 10 & 5 & 5 & 5 & 5 & 5 & 5 & 4 & 5 & 5 \\
\hline A3 & 15 & 0 & 0 & 0 & 1 & 1 & 0 & 1 & 0 & 1 \\
\hline A4 & 20 & 2 & 3 & 2 & 3 & 3 & 3 & 4 & 5 & 4 \\
\hline A5 & 10 & 3 & 2 & 3 & 3 & 4 & 2 & 2 & 2 & 3 \\
\hline A6 & 20 & 1 & 1 & 1 & 1 & 1 & 1 & 1 & 1 & 1 \\
\hline A7 & 0 & 3 & 0 & 0 & 5 & 0 & 0 & 0 & 0 & 0 \\
\hline A9 & 10 & 4 & 5 & 5 & 5 & 5 & 5 & 5 & 5 & 4 \\
\hline A10 & 0 & 2 & 2 & 1 & 1 & 1 & 0 & 0 & 0 & 1 \\
\hline B1 & 0 & 4 & 4 & 4 & 4 & 4 & 3 & 4 & 4 & 4 \\
\hline B2 & 5 & 5 & 5 & 5 & 5 & 5 & 5 & 5 & 5 & 5 \\
\hline B4 & 5 & 5 & 1 & 1 & 1 & 1 & 1 & 2 & 2 & 5 \\
\hline B5 & 0 & 5 & 3 & 3 & 2 & 2 & 3 & 5 & 5 & 5 \\
\hline B6 & 0 & 3 & 3 & 3 & 3 & 3 & 3 & 3 & 3 & 3 \\
\hline B7 & 0 & 1 & 1 & 1 & 1 & 1 & 1 & 1 & 1 & 1 \\
\hline B8 & 0 & 4 & 1 & 1 & 1 & 1 & 1 & 1 & 1 & 1 \\
\hline B9 & 0 & 4 & 1 & 1 & 1 & 1 & 1 & 1 & 1 & 1 \\
\hline C6 & 5 & 5 & 5 & 5 & 5 & 5 & 5 & 5 & 5 & 3 \\
\hline C7 & 0 & 1 & 5 & 1 & 1 & 3 & 5 & 3 & 3 & 1 \\
\hline & Média & $\mathbf{2 5 5}$ & $\mathbf{2 5 5}$ & $\mathbf{2 4 5}$ & $\mathbf{2 8 0}$ & $\mathbf{2 9 0}$ & $\mathbf{2 5 5}$ & $\mathbf{2 8 5}$ & $\mathbf{3 0 0}$ & $\mathbf{3 0 0}$ \\
\hline
\end{tabular}

Tabela 5.3.2e- Cálculo do interesse científico no Geossit. 1-Pedra do Sino, 2-Pico do Baepi, 3Cachoeira do Gato, 4-Pr.da Figueira, 5-Pr.de Enchovas, 6-Buraco do Cação, 7-Diques da Ponta da Sela, 8-Gabros estratiformes e 9-Pr.do Portinho. 


\begin{tabular}{|c|c|c|c|c|c|c|c|c|c|c|}
\hline $\begin{array}{c}\text { Int. } \\
\text { Didático }\end{array}$ & Peso & $\mathbf{1}$ & $\mathbf{2}$ & $\mathbf{3}$ & $\mathbf{4}$ & $\mathbf{5}$ & $\mathbf{6}$ & $\mathbf{7}$ & $\mathbf{8}$ & $\mathbf{9}$ \\
\hline $\mathrm{A} 1$ & 5 & 5 & 5 & 5 & 5 & 5 & 5 & 4 & 5 & 5 \\
\hline A3 & 10 & 0 & 0 & 0 & 1 & 1 & 0 & 1 & 0 & 1 \\
\hline A4 & 5 & 2 & 3 & 2 & 3 & 3 & 3 & 4 & 5 & 4 \\
\hline A5 & 10 & 3 & 2 & 3 & 3 & 4 & 2 & 2 & 2 & 3 \\
\hline A6 & 5 & 1 & 1 & 1 & 1 & 1 & 1 & 1 & 1 & 1 \\
\hline A7 & 5 & 3 & 0 & 0 & 5 & 0 & 0 & 0 & 0 & 0 \\
\hline A9 & 5 & 4 & 5 & 5 & 5 & 5 & 5 & 5 & 5 & 4 \\
\hline A10 & 5 & 2 & 2 & 1 & 1 & 1 & 0 & 0 & 0 & 1 \\
\hline B1 & 5 & 4 & 4 & 4 & 4 & 4 & 3 & 4 & 4 & 4 \\
\hline B2 & 5 & 5 & 5 & 5 & 5 & 5 & 5 & 5 & 5 & 5 \\
\hline B4 & 10 & 5 & 1 & 1 & 1 & 1 & 1 & 2 & 2 & 5 \\
\hline B5 & 5 & 5 & 3 & 3 & 2 & 2 & 3 & 5 & 5 & 5 \\
\hline B6 & 5 & 3 & 3 & 3 & 3 & 3 & 3 & 3 & 3 & 3 \\
\hline B7 & 0 & 1 & 1 & 1 & 1 & 1 & 1 & 1 & 1 & 1 \\
\hline B8 & 20 & 4 & 1 & 1 & 1 & 1 & 1 & 1 & 1 & 1 \\
\hline B9 & 0 & 4 & 1 & 1 & 1 & 1 & 1 & 1 & 1 & 1 \\
\hline C6 & 0 & 5 & 5 & 5 & 5 & 5 & 5 & 5 & 5 & 3 \\
\hline C7 & 0 & 1 & 5 & 1 & 1 & 3 & 5 & 3 & 3 & 1 \\
\hline & Média & $\mathbf{3 3 0}$ & $\mathbf{2 0 5}$ & $\mathbf{2 0 5}$ & $\mathbf{2 4 0}$ & $\mathbf{2 2 5}$ & $\mathbf{1 9 0}$ & $\mathbf{2 2 5}$ & $\mathbf{2 2 5}$ & $\mathbf{2 7 0}$ \\
\hline
\end{tabular}

Tabela 5.3.2f- Cálculo do interesse didático no Geossit. 1-Pedra do Sino, 2-Pico do Baepi, 3Cachoeira do Gato, 4-Pr.da Figueira, 5-Pr.de Enchovas, 6-Buraco do Cação, 7-Diques da Ponta da Sela, 8-Gabros estratiformes e 9-Pr.do Portinho 


\begin{tabular}{|c|c|c|c|c|c|c|c|c|c|c|}
\hline $\begin{array}{c}\text { Int. } \\
\text { Turístico }\end{array}$ & Peso & $\mathbf{1}$ & $\mathbf{2}$ & $\mathbf{3}$ & $\mathbf{4}$ & $\mathbf{5}$ & $\mathbf{6}$ & $\mathbf{7}$ & $\mathbf{8}$ & $\mathbf{9}$ \\
\hline A1 & 0 & 5 & 5 & 5 & 5 & 5 & 5 & 4 & 5 & 5 \\
\hline A3 & 0 & 0 & 0 & 0 & 1 & 1 & 0 & 1 & 0 & 1 \\
\hline A4 & 0 & 2 & 3 & 2 & 3 & 3 & 3 & 4 & 5 & 4 \\
\hline A5 & 0 & 3 & 2 & 3 & 3 & 4 & 2 & 2 & 2 & 3 \\
\hline A6 & 0 & 1 & 1 & 1 & 1 & 1 & 1 & 1 & 1 & 1 \\
\hline A7 & 5 & 3 & 0 & 0 & 5 & 0 & 0 & 0 & 0 & 0 \\
\hline A9 & 5 & 4 & 5 & 5 & 5 & 5 & 5 & 5 & 5 & 4 \\
\hline A10 & 15 & 2 & 2 & 1 & 1 & 1 & 0 & 0 & 0 & 1 \\
\hline B1 & 5 & 4 & 4 & 4 & 4 & 4 & 3 & 4 & 4 & 4 \\
\hline B2 & 5 & 5 & 5 & 5 & 5 & 5 & 5 & 5 & 5 & 5 \\
\hline B4 & 10 & 5 & 1 & 1 & 1 & 1 & 1 & 2 & 2 & 5 \\
\hline B5 & 5 & 5 & 3 & 3 & 2 & 2 & 3 & 5 & 5 & 5 \\
\hline B6 & 5 & 3 & 3 & 3 & 3 & 3 & 3 & 3 & 3 & 3 \\
\hline B7 & 10 & 1 & 1 & 1 & 1 & 1 & 1 & 1 & 1 & 1 \\
\hline B8 & 0 & 4 & 1 & 1 & 1 & 1 & 1 & 1 & 1 & 1 \\
\hline B9 & 15 & 4 & 1 & 1 & 1 & 1 & 1 & 1 & 1 & 1 \\
\hline C6 & 15 & 5 & 5 & 5 & 5 & 5 & 5 & 5 & 5 & 3 \\
\hline C7 & 5 & 1 & 5 & 1 & 1 & 3 & 5 & 3 & 3 & 1 \\
\hline & Média & $\mathbf{3 5 0}$ & $\mathbf{2 6 5}$ & $\mathbf{2 3 0}$ & $\mathbf{2 5 0}$ & $\mathbf{2 3 5}$ & $\mathbf{2 3 0}$ & $\mathbf{2 4 5}$ & $\mathbf{2 4 5}$ & $\mathbf{2 4 5}$ \\
\hline
\end{tabular}

Tabela 5.3.2g - Cálculo do interesse turístico no Geossit. 1-Pedra do Sino, 2-Pico do Baepi, 3Cachoeira do Gato, 4-Praia da Figueira, 5-Praia de Enchovas, 6-Buraco do Cação, 7-Diques da Ponta da Sela, 8-Gabros estratiformes e 9-Praia do Portinho.

\begin{tabular}{|c|c|c|c|c|c|c|c|c|c|}
\hline & $\mathbf{1}$ & $\mathbf{2}$ & $\mathbf{3}$ & $\mathbf{4}$ & $\mathbf{5}$ & $\mathbf{6}$ & $\mathbf{7}$ & $\mathbf{8}$ & $\mathbf{9}$ \\
\hline Média Ic & 255 & 255 & 245 & 280 & 290 & 255 & 285 & 300 & 300 \\
\hline Média Id & 330 & 205 & 205 & 240 & 225 & 190 & 225 & 225 & 270 \\
\hline Média It & 350 & 265 & 230 & 250 & 235 & 230 & 245 & 245 & 245 \\
\hline Ig & 311,7 & 241,7 & 226,7 & 256,7 & 250 & 225 & 251,7 & 256,7 & 271,7 \\
\hline
\end{tabular}

Tabela 5.3.2h - Cálculo do interesse global (Ig), a partir da média aritmética das médias dos interesses didático (Id), científico (Ic) e turístico (It) no Geossit.1-Pedra do Sino, 2-Pico do Baepi, 3Cachoeira do Gato, 4-Praia da Figueira, 5-Praia de Enchovas, 6-Buraco do Cação, 7-Diques da Ponta da Sela, 8-Gabros estratiformes e 9-Praia do Portinho. 


\section{SUGESTÕES DE GESTÃO DO PATRIMÔNIO GEOLÓGICO DE ILHABELA}

Conhecendo todos os passos já bem estabelecidos pela literatura para a geoconservação, não é possível se abster de imaginar quais providências seriam úteis para a manutenção dos geossítios e incentivo à visitação.

Há que se levar em consideração que tanto a gestão quanto a interpretação do patrimônio geológico demandam pesquisa extensa sobre o perfil do visitante e da comunidade que vive no local a sofrer a intervenção, bem como sobre os melhores métodos para atingir educacionalmente e construtivamente o observador.

A gestão reclama o conhecimento da legislação em todos os âmbitos do executivo (municipal, estadual e nacional); o conhecimento de arquitetura, para a melhor utilização do espaço e aproveitamento de luz natural, entre outros aspectos; engenharia, no uso dos materiais e cálculo de estruturas, quando for o caso; biologia, para que a intervenção esteja em harmonia e não interfira com a biodiversidade; profissionais das ciências humanas em vários âmbitos (geografia, psicologia, turismo) para levantar e interpretar os índices sociais e as idiossincrasias da comunidade, de modo a minimizar os impactos negativos e otimizar os pontos positivos desta intervenção.

A interpretação requer pesquisa não somente sobre o conteúdo a ser divulgado, mas também sobre os tipos de materiais que vão suportar bem as condições climáticas da região e, especificamente, os adequados para resistir aos agentes de intemperismo mais intensos e pontuais; sobre a linguagem apropriada e a melhor disposição gráfica, de modo que seja interessante, estimule a leitura e veicule bem o conteúdo (principalmente no caso de material visual); sobre o modo interpretativo mais adequado para atingir o público, etc.

Estas e muitas outras particularidades da interpretação ambiental são objeto de pesquisa extensa de vários autores desde há muito, como Freeman Tilden, Sam Ham, Thomas Hose e, no Brasil, Jane Vasconcelos, Katia Mansur e Jasmine Moreira. 


\subsection{POR QUE PROCEDER À GESTÃO?}

A gestão é etapa integrante e necessária de uma estratégia de geoconservação (BRILHA, 2005) e compreende iniciativas de monitoramento, proteção, interpretação e outras, que, conjugadas, garantam a conservação do patrimônio geológico e seu uso sustentável, sempre que for possível.

Retomando a definição de Burek \& Prosser (2008), a geoconservação é "uma ação tomada com o objetivo de conservar e enaltecer características geomorfológicas, processos, sítios e espécimes".

Brilha (2005) afirma que o sentido restrito da geoconservação é a conservação de certos elementos da geodiversidade que apresentem um valor acima da média. Porém, em sentido mais amplo, promove o uso sustentável dos recursos geológicos.

Worton $^{1}$ (2008, apud Mansur, 2010) inclui na geoconservação as atividades desenvolvidas no intuito de salvaguardar as feições e os processos geológicos para as gerações vindouras. Mansur (2010) adiciona que estas ações visam garantir o acesso à história da Terra desde sua origem até os dias atuais, tanto por pesquisadores como pela população em geral.

Dentre as iniciativas de gestão, Gray (2004) sugere diversas, que variam desde a restrição de acesso até a modificação dos regimes de propriedade do local, passando pela educação e políticas públicas. O tipo de ação a ser tomada deve preconizar a garantia da integridade do patrimônio geológico sem excluir seu uso público (BRILHA, 2005). Alguns autores, como Carcavilla-Urquí, Martinez \& Valsero (2007), defendem a divulgação e interpretação do patrimônio geológico prioritariamente em áreas protegidas (mas não restrita a elas), para evitar a depredação e aproveitar a conexão deste com a biodiversidade circundante, por exemplo.

Entre as iniciativas de gestão que passam pela interpretação, podemos considerar painéis interpretativos, folhetos, guias turísticos ou geológicos, textos em websites, estabelecimento de trilhas, instalação de mirantes e treinamento de monitores (DIAS \& BRILHA, 2004). Não se avaliou profundamente ainda o alcance

${ }^{1}$ WORTON, G.J. A historical perspective on local communities and geological conservation. In: BUREK, C.V.; PROSSER, C.D. History of Geoconservation. London: Geological Society of London. Special Publication 300. 2008, p.137-146. 
destas iniciativas em relação à mudança de hábitos e intensidade de transmissão de conhecimento (HOSE, 2000), porém inúmeros são os exemplos de gestões interpretativas que têm sido bem sucedidas, como a Casa das Pedras Parideiras, no Geoparque Arouca, ou o Centro de Interpretação Geológica em Zumaia, no Geoparque da Costa Basca.

A escolha das providências a serem tomadas devem levar em conta as características do geossítio, dos visitantes (turistas), habitantes e políticas administrativas locais. É, também, prática já consolidada em vários países os projetos de geoparques, verdadeiras ferramentas de gestão territorial que se apoiam em três pilares: geoconservação, desenvolvimento social e educação. Um geoparque pode fornecer oportunidades para potencializar o turismo de um local, tentando garantir a geoconservação do patrimônio geológico através das ferramentas de gestão implementadas em cada geossítio e da educação, que se traduz em treinamento para professores, capacitação de monitores e atividades educacionais para diversos tipos de públicos e faixas etárias.

\subsection{O QUE É INTERPRETAÇÃO?}

Segundo Nunes² (1991, apud MOREIRA, 2012), a interpretação nasceu nos Estados Unidos, através da publicação de um artigo sugerindo a confecção de panfletos para explicar fenômenos naturais aos visitantes dos parques. Porém, é notório que o conceito de interpretação foi introduzido por Freeman Tilden em 1957, com o livro "Interpreting our heritage", que é referência na área.

Em seu texto, Tilden (1977) define a interpretação como "uma atividade educativa cujo objetivo é revelar os significados e as relações através do uso de objetos originais, pela experiência de primeira mão e por meios ilustrativos, ao invés de simplesmente comunicar informação factual" (p.8).

Porém, o próprio Tilden reforça que esta é uma definição para dicionários, e que, na verdade, pensando de forma mais abrangente e mais conectada com a realidade da empreitada, a interpretação é "a revelação de uma verdade maior que

${ }^{2}$ NUNES, M.L. Interpretação da natureza. Paper para o Mestrado em Engenharia Florestal Setor de Ciências Exatas Naturais. Universidade Federal do Paraná, Curitiba, 1991, p.20. 
se esconde atrás de um fato" e que "deve aproveitar a curiosidade simples para enriquecer a mente e o espírito humanos" (TILDEN, 1977).

Herbert (1989) postula que a interpretação tem o objetivo duplo de contemplar tanto os interesses do público que procuram ver e vivenciar um local, quanto os do local propriamente dito. "A boa interpretação valoriza o sítio aos olhos dos visitantes; maior valor levará a uma convicção mais forte da necessidade de preservar e proteger" (HERBERT, 1989; p.451).

Considerando o resultado de pesquisas pregressas, Hose (1997) conclui que a interpretação geológica apropriada atrai, segura e informa o turistas. Ele também cita Light ${ }^{3}$ (1995, apud HOSE, 1997) ao dizer que a interpretação fomenta a indústria do turismo, sendo um produto de valor agregado. Não se pode, portanto, olvidar o papel do turismo no desenvolvimento econômico de uma região, especialmente em uma como Ilhabela, que é estância balneária e cuja economia depende fortemente desta atividade.

Tilden (1977) postulou as seis leis da interpretação ${ }^{4}$ como sendo:

1. A interpretação será estéril se não relacionar o que está sendo descrito com a personalidade ou experiência do visitante. Por isso, deve ser específica para o público.

2. Não basta apresentar os fatos, a interpretação é a revelação baseada na informação.

3. A interpretação é uma arte que combina muitas artes, não importando se o material apresentado é científico, histórico ou arquitetônico.

4. Interpretação não é instrução, é provocação, que incita as pessoas a alguma ação.

5. A interpretação deve mostrar a relação entre as coisas; mostrar o todo e não somente as partes.

${ }^{3}$ LIGHT, D. Visitors' use of interpretive media at heritage sites. In: Leisure Studies, v.14, p. 132-149, 1995.

${ }^{4}$ Durante o Congresso Internacional de Geoturismo, que ocorreu em novembro de 2011, sob as auspícios da UNESCO, foi publicada a Declaração de Arouca, um documento resultante das discussões ocorridas durante o evento. Entre outros pontos importantes, são relembrados os princípios de Tilden e sugerida sua aplicação ao patrimônio geológico. (http://www.geoparquearouca.com/geotourism2011/adm/upload/30.declaracao_de_arouca_pt.pdf) 
6. A interpretação para crianças não deve ser somente uma diluição da apresentação para os adultos. Deve seguir uma abordagem diferente. Idades diferentes apresentam necessidades diferentes.

Para Vasconcelos (2003), a interpretação ambiental traduz a linguagem da natureza para o ecoturista, informando, educando e divertindo. A autora determina quatro características essenciais da abordagem interpretativa: é amena (que entretém), é pertinente (tem significado e é pessoal, ou seja, relaciona-se com a experiência do indivíduo), é organizada (não requer muito trabalho da audiência, ou seja, é mais fácil de ser acompanhada) e é temática (procura comunicar uma mensagem, ou tema, que funciona como um fio condutor).

Um apanhado de exemplos de meios interpretativos existentes e de suas caraterísticas mais importantes pode ser encontrado em Moreira (2012). Entre os meios personalizados, estão:

- Trilhas interpretativas: as trilhas são conduzidas por um condutor devidamente capacitado como intérprete, que realiza um trabalho educativo e pode exercer um maior controle do comportamento do público, minimizando impactos.

- Excursões e roteiros geológicos: a oferta de roteiros impacta no aumento de gastos turísticos, beneficiando economicamente os locais.

- Palestras: ou sua versão mais informal, os "talks", que devem ser disponibilizados aos visitantes e à comunidade.

Entre os meios interpretativos não personalizados, Moreira (2012) destaca:

- Trilhas autoguiadas: sem o acompanhamento de monitor, mas com pontos pré-determinados, onde o visitante recebe informações, através de painéis, panfletos ou mesmo áudio.

- Painéis interpretativos: o meio mais popular. Devem ser elaborados de modo a se tornarem atrativos, não destoarem do entorno e apresentarem uma linguagem voltada para o perfil do visitante, que é geralmente leigo.

- Material impresso: tais como guias de campo e folders, que podem ser genéricos ou mais específicos nos assuntos abordados e cuja venda é economicamente interessante para a organização, além de servir como lembrança.

- Material audiovisual: é um meio interessante para veicular a informação pois admite um volume maior em menor espaço de tempo. Além disso, recursos gráficos auxiliam na compreensão de temas e processos mais complexos. 
- Website: pode ser utilizado como ferramenta interpretativa e meio de divulgação científica e há a possibilidade de consulta em qualquer lugar e a qualquer hora. Se estiver em várias línguas, fica acessível a visitantes estrangeiros também.

- Jogos e atividades lúdicas: estimulam a criatividade, veiculam a informação de maneira divertida e podem ser jogados em escolas e em casa, além do parque.

- Museu e exposições: informações mais simples são passadas com maior rapidez; se a exposição for bem estruturada, pode conseguir manter a atenção do visitante pelo tempo necessário para que a mensagem seja captada.

Finalmente, Mansur et al. (2005) mencionam a importância ecológica da interpretação geológica, que desperta no indivíduo o sentimento de respeito pelas gigantescas forças da natureza, as mesmas que construíram estruturas e paisagens nas quais o observador habita, transita, sobrevive e das quais depende.

Acrescente-se a isso a noção do tempo geológico, imprescindível e tão difícil de ser absorvida para algumas pessoas: todo esse processo evolutivo da paisagem se estende por um tempo muito maior do que o turista leigo poderia supor, a princípio, fazendo com que a preservação assuma uma dimensão muito maior do que somente "não poluir rios" e "não matar os animais ameaçados de extinção".

\subsection{O QUE ESPERAR DAS INICIATIVAS DE GESTÃO?}

As ideias aqui apresentadas não pretendem ser a solução final para um processo que, na verdade, deve ser desenvolvido por uma equipe, de preferência integrada por profissionais da área de arte, turismo, propaganda, línguas e ciências biológicas, entre outras, além daqueles das ciências da terra.

A valorização destes profissionais ainda é tímida, mas sua contribuição é extremamente valiosa, pois coopera com os aspectos multidisciplinares que fazem de certos geossítios possíveis vórtex de conhecimento mais amplo, (entre áreas inter-relacionadas), e de conscientização ambiental, especialmente se utilizam a linguagem correta e apresentação visual didática e interessante.

A interpretação geológica não deve ser feita em todos os geossítios de um inventário, ainda que seja financeiramente possível, mas sim em casos onde a visitação é razoavelmente constante e onde as características do local suscitam perguntas. Adicionalmente, pontos que não são geossítios, mas que se configuram 
em interessantes locais para interpretação, podem e devem receber iniciativas neste sentido.

Outro caso particular onde a interpretação pode surtir efeito na preservação é em locais onde a possibilidade de vandalismo é grande. Os meios de interpretação não devem ser restritos a painéis e folhetos, mas devem englobar iniciativas de educação ambiental que podem ser estendidas desde as escolas e seus alunos e professores, até a comunidade em geral e aos turistas.

O resultado esperado de iniciativas como estas é que o indivíduo propenso ao vandalismo entenda o valor daqueles elementos presentes no geossítio, relacionese com esta identidade e aproprie-se dela, sentindo-se, dessa forma, responsável pelo seu local e a preservação dele. Conforme explica uma citação escrita por um guarda florestal anônimo para um manual americano antigo (HAM, 2009): "através da interpretação, o entendimento; pelo entendimento, o apreço; por causa do apreço, a proteção".

Entre os objetivos do trabalho de interpretação geológica, estão: facilitar ao visitante enxergar as características pelas quais um determinado elemento da geodiversidade foi valorizado pelo grupo que o estuda e as razões pelas quais ele deve ser preservado, que informações ele traz em si auxiliar o observador a responder as perguntas mais comuns que ele mesmo se faz quando admira aquele elemento (Como foi formado? Como chegou até aqui? Por que tem essa cor/forma? Por que brilha? Tem ouro/diamante?)

Ideal seria que a comunidade local fosse incluída no processo de desenvolvimento das iniciativas de interpretação desde o começo, ajudando, por exemplo, a decidir se o formato será uma placa, uma instalação, folhetos, etc. Durante a confecção, jovens artistas locais, conhecidos por sua arte em grafitismo podem contribuir na arte visual; professores de português e inglês da comunidade, na redação dos textos; arquitetos e engenheiros, na escolha do material da eventual placa e na escolha do melhor local para sua instalação; marceneiros, vidraceiros e ferreiros locais podem ser contratados para fazer o material, a ser instalado por profissionais da construção civil que também residem na comunidade.

Não se pretende com isso minimizar a importância do conhecimento organizado e esquematizado acadêmico, mas sim de estabelecer a comunicação 
entre este mundo e o não acadêmico e incluir os moradores do local na iniciativa que vai modificar o espaço onde eles mesmos vivem.

Analogamente, o patrimônio cultural imaterial associado aos locais dos geossítios também deve ser valorizado, já que há uma profunda dependência entre ele e o patrimônio material cultural e natural (UNESCO, 2003). A iniciativa de relatos de história oral real ou fictícia, (especialmente do folclore relacionado à geodiversidade e biodiversidade presentes no local) e do ensino do artesanato pelos indivíduos mais idosos da comunidade pode contribuir com a manutenção deste conhecimento. Durante décadas ou às vezes, séculos, este tipo de informação foi transmitido oralmente. Porém, com o advento das telecomunicações e meios digitais, vai perdendo força a passos largos (FREITAS \& COSTA, 2011).

Além disso, esta iniciativa valoriza e recoloca o idoso na comunidade sem associá-lo às concepções depreciativas vigentes, resultados de uma construção sócio-histórica e midiática (OLIVEIRA \& SANTOS, 2009; SIQUEIRA et al, 2002), contribuindo para o resgate de valores como o respeito por sua visão de mundo e experiência de vida, que foram substituídos pela importância da juventude, da beleza física e da sensualidade, na sociedade brasileira atual.

Segundo Schimidt \& Cainelli, (2004), a história oral também pode introduzir o indivíduo na comunidade à qual ele pertence e promover a criação de identidade, fortalecendo "o respeito pelo patrimônio que testemunho o passado local e os termos das questões relativas à administração e gestão do território em que vivem", entre outras coisas (PARANÁ, 2008, p.71).

Todas estas iniciativas, convém lembrar, também são pilares importantes para o eventual desenvolvimento de um geoparque. Brilha (2009) afirma que os geoparques podem ilustrar a dependência dos aspectos físicos, biológicos e culturais de uma região e este é um pilar do paradigma da sustentabilidade. Ademais, corroboram o conceito de educação ambiental veiculado pela $\mathrm{CDMA}^{5}$ (2000, apud MANSUR et al., 2005):

"são os processos através dos quais o indivíduo e a coletividade constroem valores sociais, conhecimentos, atitudes, habilidades, interesse ativo e competência voltados

${ }^{5}$ CDMA - Comissão de Defesa do Meio Ambiente da ALERJ e Defensores da Terra. Educação ambiental: como elaborar um projeto de educação ambiental: tudo sobre a Lei Estadual 3325/99: texto comentado. Rio de Janeiro: ALERJ, 2000. 20 p. 
para a conservação do meio ambiente, bem de uso comum do povo, essencial à sadia qualidade de vida e sua sustentabilidade".

\subsection{QUEM SERÁ O RESPONSÁVEL?}

A primeira providência a ser tomada é definir que órgãos serão responsáveis pela gestão dos geossítios e qual seu escopo de abrangência.

Os geossítios Pico do Baepi, Cachoeira do Gato, Praia da Figueira e Buraco do Cação são parte integrante do PElb e portanto, cabe ao parque a gestão destes locais.

Os geossítios localizados nas praias e costões, como o são a Pedra do Sino (Praia de Garapocaia), Praia de Enchovas, Diques da Ponta da Sela, Gabros estratiformes e Praia do Portinho são bens da União, segundo a constituição. Por isso, não há figura de proteção ou manutenção específica aliada a eles, exceto a das atribuições municipais. Ainda, o acesso aos geossítios Diques da Ponta da Sela, Gabros Estratiformes e Praia do Portinho cortam propriedades privadas (o geossítio Praia do Portinho, porém, pode às vezes ser acessado pela praia - é necessário entrar na água - em dia de boas condições de tempo).

É importante que haja uma estrutura de gestão organizada, que pode ser constituída por indivíduos "emprestados" de vários órgãos representativos da comunidade, e que estabeleça parcerias com as universidades (para o aporte e manuseio de informações de caráter científico ${ }^{6}$ ), aos moldes do que acontece em um geoparque. Assim, a designação de um grupo de trabalho, preferencialmente multidisciplinar, trabalhando sob a égide da prefeitura ou do PElb, pode favorecer a geoconservação do patrimônio geológico de llhabela.

Para expor as sugestões de gestão, esta "organização gestora" que sugerimos ser criada e que, por hora, é fictícia, será doravante referida como OG. Entende-se por "organização gestora" qualquer grupo de trabalho, criado especificamente para este fim ou não, ou órgão responsável pela gestão dos geossítios.

${ }^{6}$ Como é, por exemplo, o papel do NAP GeoHereditas, ao fazer o inventário da região e que pode participar da parte científica desta gestão. 


\subsection{SUGESTÕES GERAIS}

\subsubsection{Sites}

A fim de incentivar o geoturismo em Ilhabela, consideramos importante que as informações sejam veiculadas na Internet. $O$ investimento pode ser moderado e este pode ser um passo anterior a qualquer outra iniciativa de interpretação. Para isso, sugere-se o desenvolvimento de uma página que contenha os seguintes tópicos:

- A história geológica da ilha e dos arredores;

- Informações operacionais sobre os geossítios: acesso, vestimenta adequada, atividades que possam ser desempenhadas no local (caminhadas, mergulho, natação, observação de aves e insetos - coleópteros, por exemplo -, etc);

- Infraestrutura disponível: se há banheiros, torneiras com água tratada, comércio de bebidas e lanches;

- Informações geológicas: a interpretação propriamente dita, com a história de formação daquele local, os tipos de rochas, os pontos que o visitante gostará de prestar mais atenção, a biodiversidade relacionada a eles, bem como fatos históricos e folclóricos, com ilustrações. Vídeos e animações gráficas são um adicional interessante e que auxiliam no entendimento dos processos geológicos e fenômenos naturais ${ }^{7}$;

- Os cuidados especiais que devam ser tomados quando o visitante estiver no local: exposição ao sol, picadas de insetos, rochas escorregadias, etc.

O interessante de uma página de internet é que a informação pode ser estruturada em níveis, cujo acesso pode ser dado por hyperlinks, ou seja, o leitor mais leigo pode se contentar com a informação mais superficial, sem se alarmar ao ver uma quantidade grande de textos. Analogamente, ao leitor mais acadêmico é facultado navegar em direção às seções mais específicas, que podem, inclusive, conter links para publicações científicas importantes sobre as rochas, os fenômenos e processos, e a geologia regional, por exemplo.

7 Atualmente, o NAP GeoHereditas está desenvolvendo um website com as informações pertinentes aos geossítios, que serão incluídos conforme forem certificados através das publicações científicas nas quais constarem. 


\subsubsection{Guia geológico e roteiros geoturísticos}

A exemplo do que ocorre no Geoparque da Costa Basca, o desenvolvimento de um guia geológico em lugar da colocação de painéis interpretativos pode ser uma alternativa viável financeiramente.

O Geoparque da Costa Basca apresenta dois estratotipos reconhecidos com o "golden spike" da ICS (Comissão Internacional de Estratigrafia), quilômetros de extensão de afloramento de flysch, com limites importantes como o K-T (cretáceoterciário, que marca a extinção dos dinossauros) e dezenas de outras atrações de alto valor científico e estético (como os poljes, por exemplo). Instalar painéis em todos os pontos seria praticamente inviável, além de comprometer a estética dos locais.

Atentando para este fato, a entidade gestora, na figura principalmente de seu diretor científico, Asier Hilario, decidiu não instalar placas interpretativas, a não ser onde fosse absolutamente necessário (como, por exemplo, na recém-inaugurada "Rota dos Mirantes", uma trilha autoguiada de dois dias que passa pelos mirantes do parque - Hilario, 2013; informação verbal ${ }^{8}$ ). Ao invés disso, optou por pequenas plaquetas sinalizando os pontos com letra e número (Fig. 6.5.2), que remetem a textos em um guia vendido nos centros de recepção turística das cidades que compõem o geoparque .

Do mesmo modo, acreditamos que a confecção de um guia geológico pode ser uma solução eficiente e de baixo custo (já que o investimento inicial é recuperado com a venda), especialmente se for desenvolvido de modo a agradar leigos e expertos. Para os leigos, as ilustrações, explicações sem exagero de jargão científico, imagens e fotografias de alta qualidade, podem fazer com que o guia se torne, a exemplo que cita Moreira (2012), um souvenir. Para aqueles que já estão familiarizados com a geologia, uma seção mais elaborada do assunto e a sugestão de publicações, pode ser bastante interessante.

O guia pode remeter a um site nos moldes que foi sugerido na seção anterior através do link ou de QRcodes, complementando a oferta de informações a pesquisadores e alunos da área de ciências da terra.

\footnotetext{
${ }^{8}$ Informação fornecida por Asier Hilario, em Zumaia, País Basco, em julho de 2013.
} 
Além disso, o guia pode oferecer sugestões de "trajetos geológicos" que não necessariamente passem pelos geossítios, ou não os contemplem em sua totalidade, mas que sejam ligados por um tema, um "fio condutor". Um exemplo seria um roteiro geoturístico que privilegiasse "as diferentes rochas alcalinas de Ilhabela", saindo da Praia do Jabaquara, no norte da ilha, onde se veem blocos de enormes dimensões, com caneluras muito pronunciadas, passando pelos fonolitos da Pedra do Sino, onde as rochas têm som e terminando no Buraco do Cação.

Para finalizar, o guia poderia colecionar um "selo geológico" para cada local visitado, com um brinde quando completasse todos os roteiros e visitações sugeridas no guia, nos mesmos moldes do Passaporte de Trilhas de SP da Secretaria do Meio Ambiente.
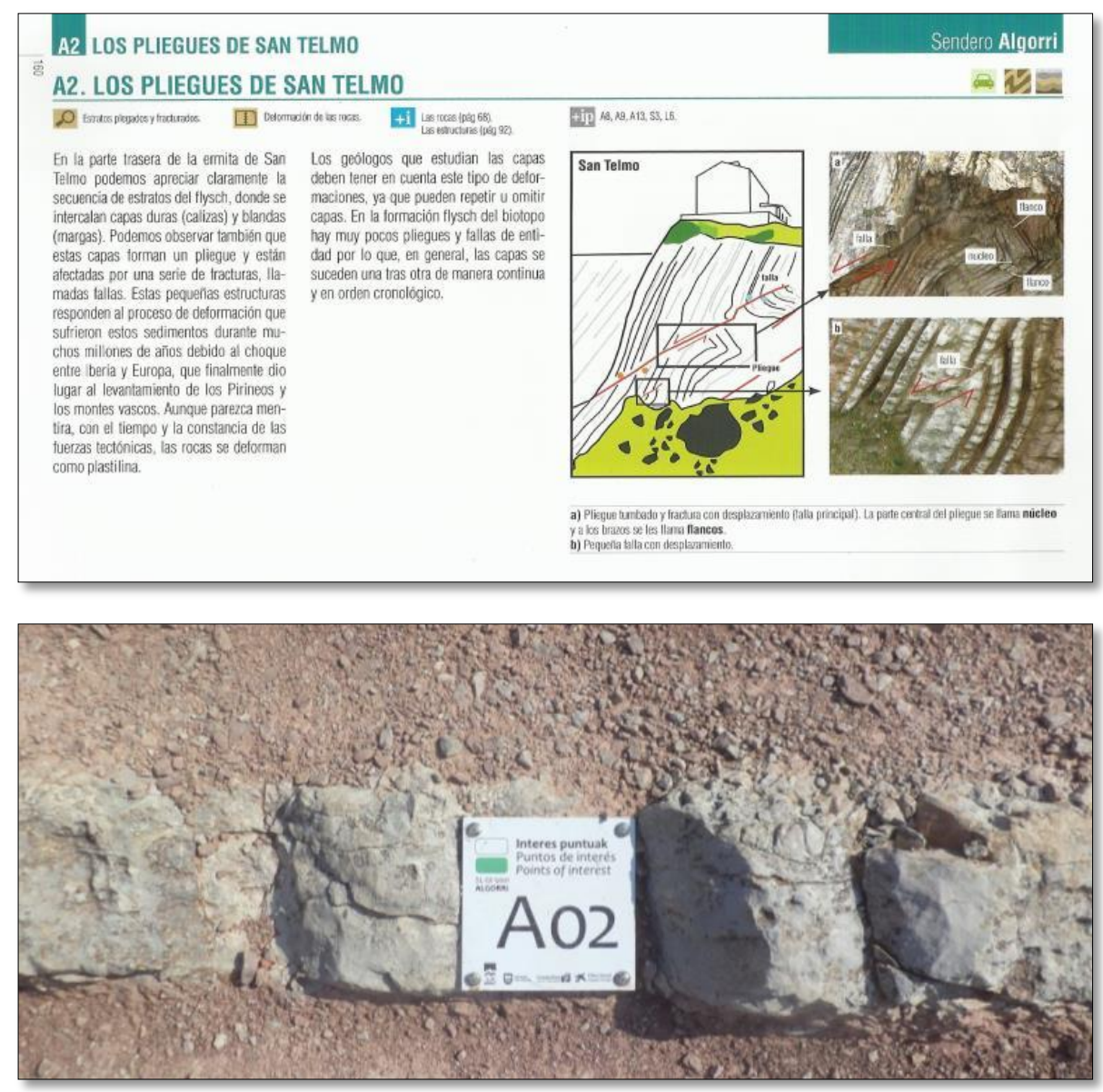

Figura 6.5.2 - A sinalização utilizada para interpretação geológica no Geoparque da Costa Basca, que alia plaquetas nos locais (abaixo) com um código que remete às explicações em um guia (acima). As plaquetas têm cerca de $10 \mathrm{~cm}$ de lado e estão afixadas no solo. 


\subsubsection{Capacitação de guias turísticos}

Segundo dados do site da Secretaria de Turismo de Ilhabela, há 15 empresas de receptivo turístico, com oferta de passeios de jipe, de barco, prática de mergulho, canoagem e SUP (stand-up paddle), além de passeios a trilhas e cachoeiras. Além disso, o Parque Estadual de Ilhabela conta com monitores e outros funcionários que também desempenham este papel, especialmente na alta temporada.

A prefeitura de Ilhabela vem tentando capacitar o receptivo turístico com cursos de formação que versam sobre variados temas, incluindo a arqueologia e a geologia da ilha. Concomitantemente, o NAP GeoHereditas vem capacitando os monitores dos parques estaduais que cobrem o litoral do estado, com cursos que oferecem uma parte teórica de Introdução às Geociências e uma parte prática, geralmente feita em uma trilha de alta taxa de visitação do local, como a Trilha da Água Branca, de Ilhabela.

Depreende-se do contato com estes monitores, que estão bastante acostumados a falar sobre a biodiversidade. Porém, é necessária uma formação mais direcionada para capacitar os guias a falar das rochas, desmistificando o que os moradores convencionaram como verdadeiro. Em Ilhabela, alguns exemplos deste folclore são:

- A crença de que muitos naufrágios se deram porque a magnetita presente nas rochas e areia das praias interferiu nas bússolas dos navios. Há vários registros de naufrágios ao redor da ilha e que se estabeleceram como pontos interessantes de mergulho. Porém, há duas causas prováveis para a ilha ser uma espécie de "cemitério marinho", com cerca de 30 naufrágios ao seu redor: 1) o formato do maciço Mirante, a SE, com a Ponta do Boi, que, mesmo com o farol, era difícil de ser enxergado à noite; e 2) a maior incidência de ventos de sul e leste (Aramaqui, 2013).

- A ilha é um vulcão extinto. O folclore inclui relatos de locais por onde a lava haveria passado, deixando como rastro as "larvas", como a população caiçara mais antiga chama os diques máficos. Esta crendice deriva provavelmente do fato de que as rochas da ilha, em sua maioria, sienitos 
alcalinos e granitos, são intrusivas vulcânicas, o que teria levado o habitante leigo a entender, escutando um pesquisador, que derivavam de um vulcão e logo imaginar todo o espetáculo pirotécnico que pode haver em erupções.

- Há ouro e minerais preciosos nas proximidades do Lago Dourado, que foram escondidos pela Feiticeira. Segundo Simões (2005), a Feiticeira é uma personagem folclórica que habitava próximo à praia que leva seu nome. Dizem que era uma senhora muito rica que mantinha uma taverna para piratas e marinheiros. Tendo enlouquecido com a velhice, a senhora teria escondido todo o seu tesouro, com a ajuda de seus escravos, que matou logo em seguida. Depois disso, ela desapareceu. O Lago Dourado se localiza no sul da ilha, próximo à Cachoeira da Lage, e suas águas reluzem com a luz do sol, devido à presença de vermiculita em suspensão (Fig.6.5.3a). O efeito é bastante estético e realmente instiga a imaginação.

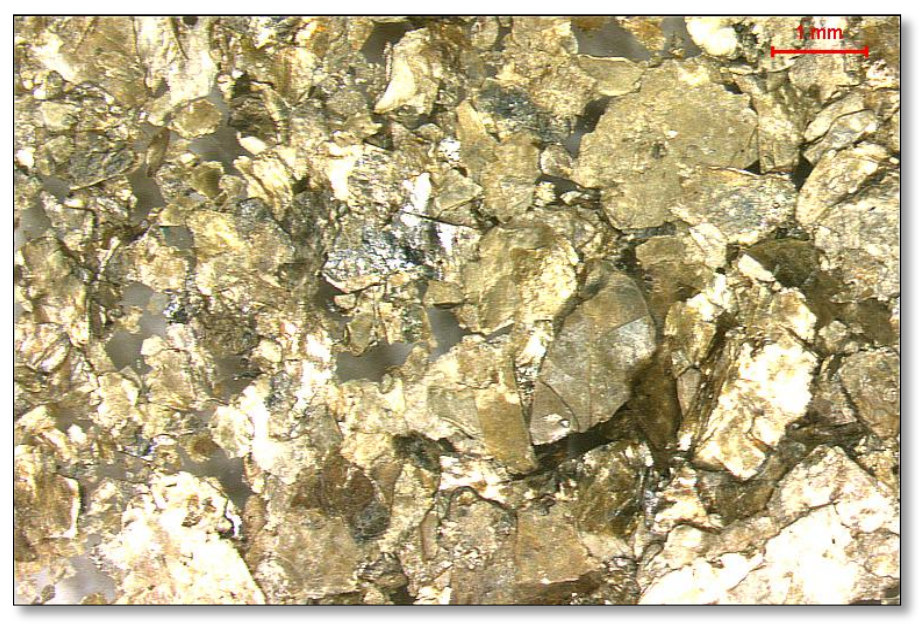

Figura 6.5.3a - Vermiculita proveniente dos sedimentos do Lago Dourado. A presença do mineral em suspensão faz a água reluzir sob a luz do sol, incentivando o folclore de que haveria um tesouro enterrado nas redondezas. Escala: $1 \mathrm{~mm}$.

\subsubsection{Capacitação de educadores}

Escolas podem ser verdadeiros multiplicadores de novos paradigmas da sociedade. Capacitar os educadores em todos os níveis de ensino (do infantil ao médio) para falar, entender e pesquisar sobre a geodiversidade da ilha é, sem dúvida, uma ótima iniciativa. 
O estabelecimento de projetos multidisciplinares, com produtos que podem ser expostos para a comunidade ao seu término, como colagens, esculturas, histórias em quadrinhos, cartazes, peças teatrais e músicas, pode engajar não somente as crianças que dele participam, mas os pais e cuidadores. Dessa forma, uma iniciativa que ficaria restrita ao ambiente escolar ultrapassa as barreiras físicas e pode permear as vidas de todos na sociedade.

É importante que a capacitação de educadores trabalhe as noções básicas de geologia, fornecendo bases teóricas, mas que também ensine aos participantes como e onde buscar as respostas para as perguntas que escutam de seus alunos e que eles mesmos se indagam.

Alia-se a esta empreitada a possibilidade de desenvolvimento de coleções didáticas nas escolas, com amostras de rochas representativas da geologia local e do litoral norte como um todo. O momento é bastante propício, já que há obras de extensão do Porto de São Sebastião e de duplicação da Rodovia dos Tamoios, com perfurações e explosões diárias que retiram toneladas de rochas.

Não é demais lembrar que a educação é um dos pilares da geoconservação, já que não é possível preservar o que não se valoriza, e não se valoriza o que não se conhece.

\subsubsection{Envolvimento dos setores comerciais: alimentação, hotelaria, artesanato.}

Visando ao geoturismo, o envolvimento dos setores comerciais é imprescindível. Faz-se necessário a promoção de pequenas palestras ou eventos onde se mostre aos grandes, médios e pequenos empresários como a exploração do tema da geodiversidade de llhabela pode alavancar a visitação, mesmo em baixa temporada - já que esta não fica restrita às praias, que são o atrativo máximo regional. Isto já ocorre com sucesso em localidades onde há geoparques, especialmente na Europa, com adesão expressiva da iniciativa privada, que abraça a causa.

Neste sentido, a OG pode promover a capacitação do pequeno empresário para a produção de artesanato com o tema da geodiversidade local, de produtores do setor alimentício para a confecção de pães e doces seguindo este mesmo tema, 
de empresários do ramo de esportes radicais e de empresas relacionadas ao receptivo de turismo. Um exemplo de empreitada como essa são os "chocolates de pirita" produzidos no Centro de Ciência Viva da Mina do Lousal, em Portugal, uma antiga mina de pirita que suspendeu suas atividades em 1988 e atualmente se dedica à conservação deste patrimônio geomineiro (Fig. 6.5.6).

Dentro deste escopo de criatividade, ideias não faltam. Por exemplo, pode-se fazer uma linha de bijuterias da Feiticeira, para ser comercializada junto com a explicação geológica do brilho do Lago Dourado. Ou echarpes tingidas na padronagem das rochas alcalinas do sul da ilha, do Buraco do Cação, que foram confundidas com charnockito por seu tom esverdeado. Podem ser produzidos bolos e pudins com ranhuras que imitem as caneluras das rochas alcalinas ao norte da ilha, pavês simulando as rochas do Portinho, ou miniaturas em papel machê da Cachoeira do Gato e do Buraco do Cação.

É notório que o engajamento do setor comercial no geoturismo pode reverter em expansão econômica para a região e, consequentemente, em desenvolvimento social.
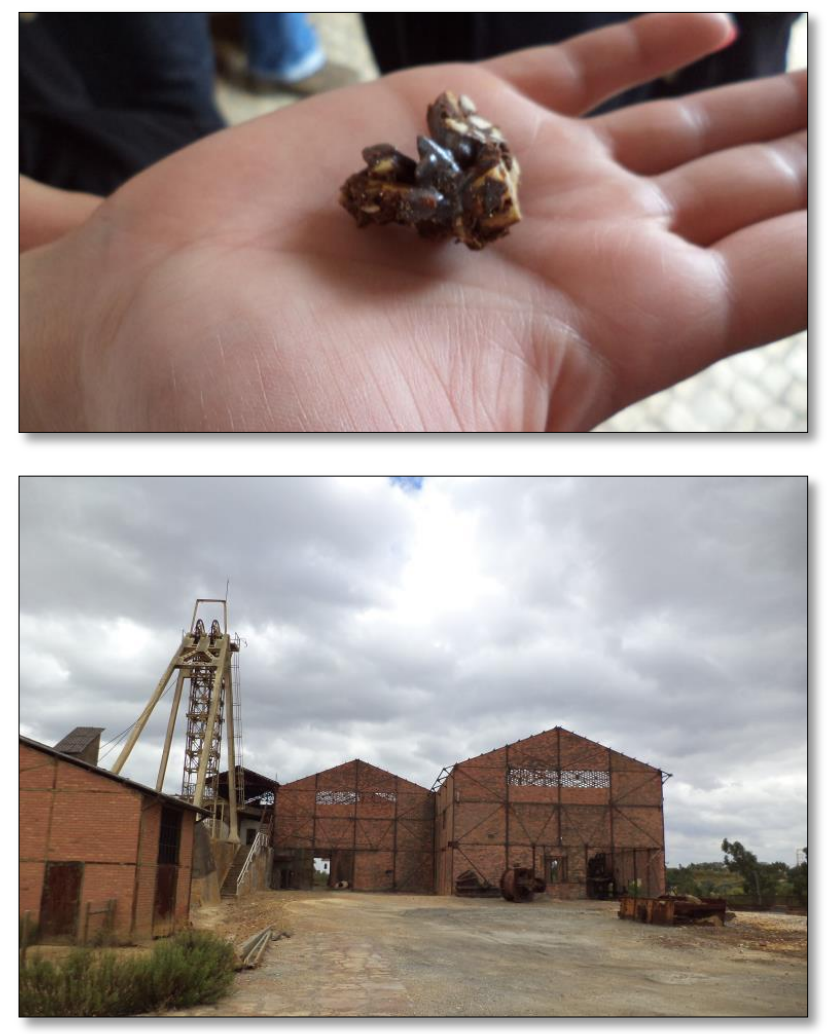

Figura 6.5.6 - Um pedaço de "chocolate de pirita" (dimensões: $3 \mathrm{~cm} \times 3 \mathrm{~cm}$ aproximadamente), feito com chocolate e amêndoas (acima), imitando o mineral que até 1988 era extraído na Mina do Lousal, Portugal (abaixo). 


\subsection{INTERVENÇÕES PONTUAIS NOS GEOSSÍTIOS}

\subsubsection{Pedra do Sino ${ }^{9}$}

A Pedra do Sino está localizada defronte a um restaurante e o acesso é possível através de uma passarela bifurcada, construída pela prefeitura (mas que sofre eventuais pequenos reparos pelo pessoal do estabelecimento), que atravessa o mar de blocos e cujas pontas culminam nos dois blocos de rocha com maior sonoridade.

O restaurante fornece aos turistas uma marreta para que possam aferir o som da rocha. Durante uma observação prolongada do comportamento dos turistas no local, em um feriado prolongado, foi possível escutar a formulação de várias teorias para explicar o som da rocha: "deve ter ferro dentro", "é oca por dentro", "é por causa do martelo, que é de ferro". Foi igualmente possível perceber que o fenômeno causa excitação nos mais curiosos que, talvez na tentativa de entender as causas do som, martelavam os blocos com mais insistência.

Sem dúvida, este geossítio é um dos locais que mais motiva a visitação turística em Ilhabela. Muitas pessoas querem ver a "pedra que faz barulho de metal". Adiciona-se a esta atração a praia localizada bem ao lado deste afloramento (Praia de Garapocaia), o mar e o clima, que convidam a ficar até aqueles que não se sentem confortáveis com as tarifas praticadas pelo restaurante.

Também são visíveis entre os blocos latinhas de cerveja vazias e lixo. Como o mar banha este afloramento, este lixo é constantemente varrido pela água, especialmente os restos de sacos plásticos, que são conhecidos por seus danos ao meio ambiente e à fauna marinha.

As sugestões de gestão deste local incluem:

- A troca do martelo de metal por um de borracha de alta densidade, que pode ser mantido pelo restaurante, ainda que fornecido pela OG, ou que esteja afixado ao lado dos blocos. A quantidade de martelos e o modo de fixação, se

9 As ideias desenvolvidas para este geossítio são resultado de discussões com os professores José B. R. Brilha e Paulo Pereira (ambos da Universidade do Minho) e John Macadam, geólogo, consultor em interpretação geológica e proprietário da empresa de interpretação Earthwords, no Reino Unido. 
escolhido, deve ser estudado de modo a convidar o visitante a experimentar o som a rocha.

- A confecção de um painel interpretativo que pode ser instalado próximo ao início da passarela, em um bloco de rocha sem sonoridade e que está fixado ao chão por suas dimensões e peso (Fig 6.6.1a). Uma porção pequena deste bloco pode ser polida, para que o observador veja a cor, a textura e os minerais da rocha fresca. ${ }^{10}$

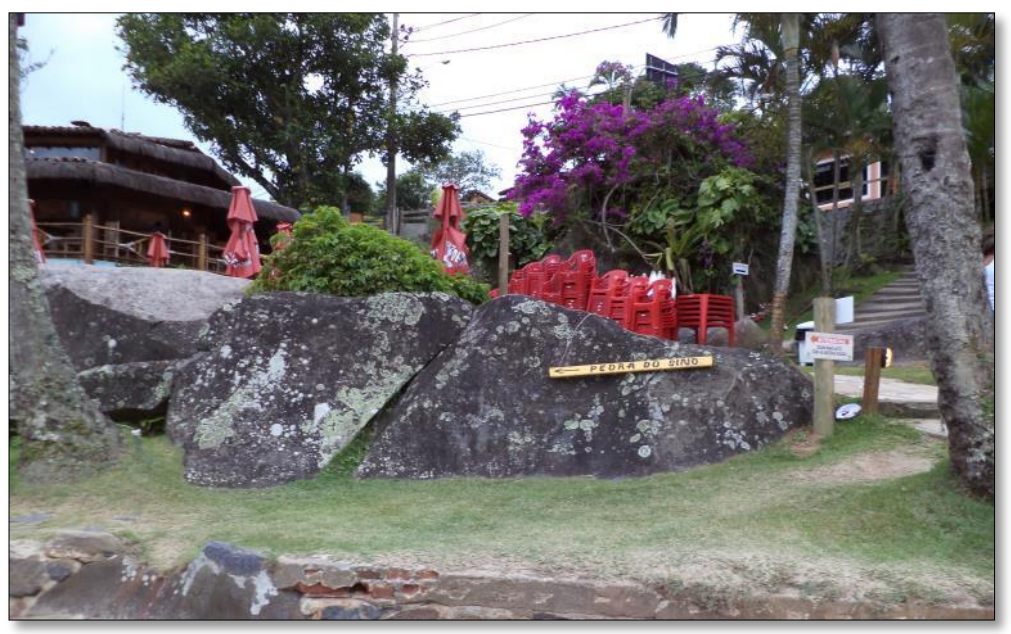

Figura 6.6.1a - Bloco de rocha localizado próximo ao início da passarela que leva aos blocos sonoros da Pedra do Sino, na Praia de Garapocaia e o restaurante Pedra do Sino, no fundo à esquerda.

- As mesmas informações desenvolvidas para um painel podem ser colocadas em descansos de prato ou nos tampos das mesas do restaurante, caso seja decidido pela não colocação do painel. Esta iniciativa deve ser pensada conjuntamente com a administração do restaurante e pode reverter em possível propaganda, já que o nome do estabelecimento é "Restaurante Pedra do Sino".

10 Está em andamento pelo GeoHereditas um projeto Fapesp que prevê a instalação de 10 painéis no litoral norte do estado de São Paulo. No momento, 4 painéis estão em fase final de confecção (Pedra do Sino, Morro do Santo Antonio, Camburizinho e Praia do Prumirim) para o início das negociações com as prefeituras dos municípios e outros seis estão em fase de decisão quanto aos melhores locais (decisão que incluirá os pesquisadores envolvidos diretamente no inventário do patrimônio geológico do litoral). 


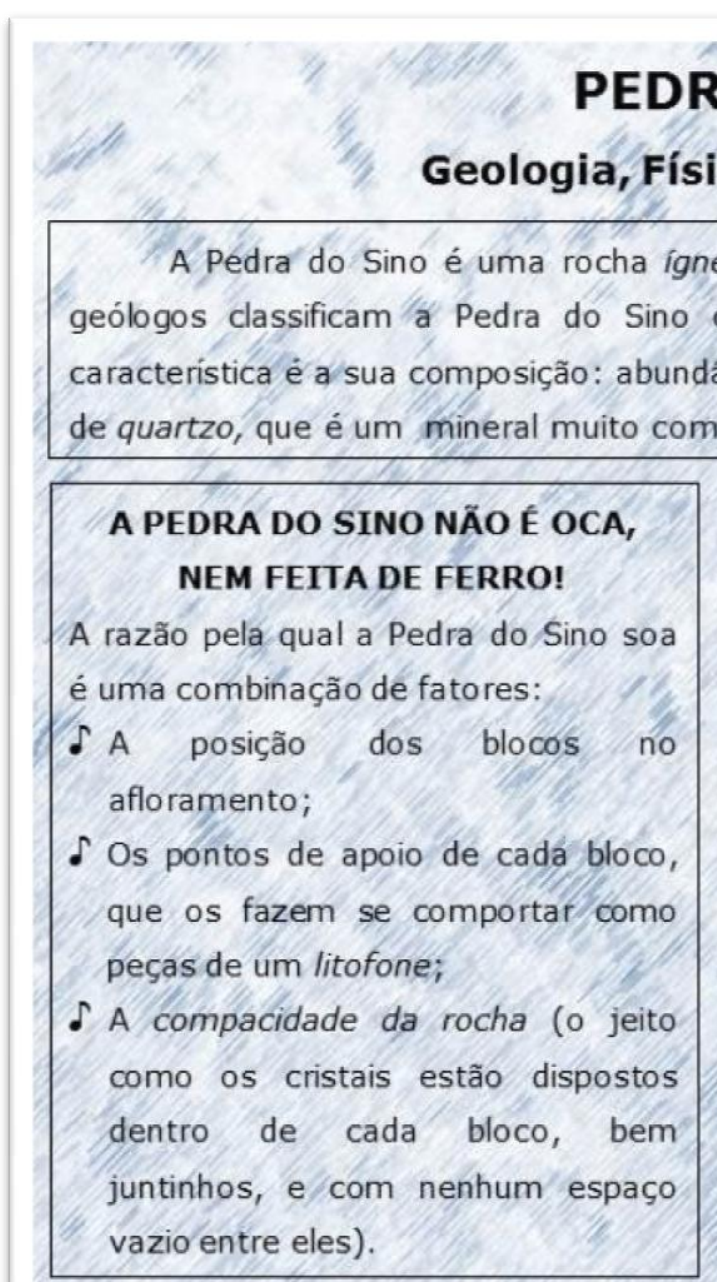

\section{A ROCHA PODE QUEBRAR?}

Com tanta gente batendo o tempo todo, ela pode rachar um dia. Por isso, cuide dela! Bata somente para escutar o som e se encantar, não para quebrar.
LONGA VIAGEM ATÉ AQUI...

Este é um mapa geológico simplificado de Ilhabela (CPRM, 2006). Observe as formas de cor verde:

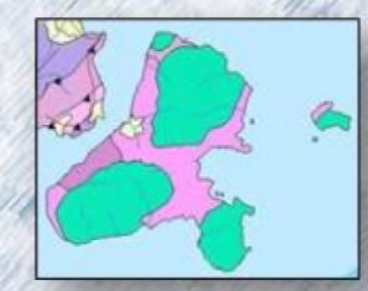

São maciços alcalinos enormes, de cerca de 80 milhơes de anos! São, na verdade, restos de câmaras magmáticas de vulcões muito antigos. Eles se solidificaram debaixo da crosta, mas foram soerguidos por movimentos tectônicos. Conforme o terreno acima deles foi erodido, ficaram mais expostos, em um processo chamado isostasia. os pontos mais altos de Ihabela estão bem em cima deles.

Para chegar até aqui, a Pedra do Sino viajou muito! Nasceu debaixo da crosta, foi soerguida, exposta, quebrada, soltou-se da montanha de rocha e rolou até a praia. Isso tudo em cerca de 80 milhões de anos!

Todos os blocos foram desenhados desta forma pelo transporte e por agentes de intemperismo (água da chuva e do mar, vento, calor e frio, plantas que crescem nas fraturas). As rochas alcalinas são esculpidas nestes desenhos especiais chamados caneluras. Você pode ver as caneluras bem marcadas nas rochas da Sirúba ou de Jabaquara, por exemplo.

Observe os blocos! Você consegue adivinhar quais pedaços provavelmente já estiveram grudados?

Figura 6.6.1b - Sugestão de painel para o geossítio Pedra do Sino. 
A confecção de um painel foi requerida pela Secretaria de Turismo em novembro de 2012 e o conteúdo, sem arte, foi entregue em março de 2013. Até a data da entrega desta dissertação, a placa ainda não havia sido instalada. No texto são usados alguns poucos termos geológicos que estão apresentados em negrito. A ideia é que haja um QRcode que remeta para um glossário online ou para um glossário em um Guia do Patrimônio Geológico de llhabela (Fig.6.6.1b).

Acredita-se que, com a valorização geológica do local e a conscientização da comunidade e visitantes de que este é um dos poucos exemplos regionais de fonolitos acessíveis, possa haver uma mudança no comportamento das pessoas, que talvez se sintam menos à vontade para jogar lixo entre os blocos. De qualquer forma, a instalação de mais lixeiras no local é imprescindível.

\subsubsection{Pico do Baepi}

A utilização deste geossítio está restrita a pessoas com bom condicionamento físico, pois a trilha que leva às lajes do cume é classificada como difícil. Ainda assim, é o único geossítio do tipo mirante deste inventário, com uma vista privilegiada de todo o canal de São Sebastião e as geoformas associadas a ele.

O local não favorece a instalação de painel - quem sobe ao cume, aprecia a vista e os custos de manutenção seriam relativamente altos, por estar em local descoberto e sujeito ao intemperismo. No entanto, assim como o visitante que sobe leva mantimentos e água, pode sentir-se confortável em adicionar à sua mochila 0 guia geológico ou um mapa dobrável, explicativo e ilustrativo do canal e suas feições. Deste modo, estando no cume, o turista pode se colocar de frente para o canal (olhando para oeste), abrir o mapa e observar e entender as informações veiculadas por este meio.

Analogamente, sabemos que na entrada da trilha há sempre um monitor do parque, responsável por fazer o monitoramento de entrada e saída de pessoas da trilha, de modo que não haja visitantes perdidos, além de fazer o controle de impacto ambiental. Este também é um ótimo ponto para a instalação de um painel com as mesmas informações do mapa e um QRcode que remeta a um site. Desta forma, o 
visitante que não conseguiu adquirir o mapa pode se munir das informações em seu tablet ou smartphone.

Quanto ao conteúdo da interpretação, deve contemplar sua característica que o torna único entre os demais: a privilegiada visão da geomorfologia do canal de São Sebastião.

Desta forma, a imagem/mapa deve conter a indicação das cidades, das praias mais conhecidas e pontos como rodoviária e balsa e estabelecimentos comerciais (hipermercados, por exemplo) que podem ou não ser visíveis do alto do Pico do Baepi, para auxiliar o observador a se referenciar. Tendo feito isso, ele pode começar a observar a informação que está sendo veiculada no mapa e que foi decidida pela equipe responsável pela interpretação.

Algumas sugestões de tópicos são: as geoformas e a breve explicação do que são; indicação das massas d'água com suas predominâncias sazonais no canal, que regulam a biota; um perfil geofísico do canal, mostrando sua profundidade e que litotipos há debaixo da água, de uma forma geral (o que ajudaria a desmistificar a ideia bastante disseminada de que a ilha flutua), etc.

No verso, podem ser incluídos esquemas simplificados do processo de formação do canal no Cenozóico, com a quebra do Gondwana e a abertura do Atlântico Sul, há cerca de 140 milhões de anos.

\subsubsection{Cachoeira do Gato}

A Cachoeira do Gato se estabelece como um corpo sienítico de grandes proporções que foi cortado por um dique máfico de caráter ainda não estudado. local já recebeu infraestrutura para evitar acidentes: há uma passarela para auxiliar o acesso até próximo da piscina de águas naturais ao pé da cachoeira e um corrimão para evitar o desequilíbrio e uma eventual queda.

Apesar de as proporções da rocha emersa serem grandes, não seria produtivo a instalação de um painel neste local, pois o eventual agrupamento de pessoas na rocha úmida dos respingos da queda d'água poderia criar alguma situação propensa a acidentes. 
No entanto, após o banho de cachoeira, os visitantes geralmente percorrem a trilha de volta à Praia de Castelhanos, onde fazem refeições, se refrescam com bebidas e tomam banho de mar. Por isso, este é um local interessante para intervenções interpretativas, pois as pessoas têm tempo para se engajar em alguma observação mais detalhada de uma explicação que objetive a valorização da Cachoeira do Gato.

A Praia de Castelhanos está localizada do lado oceânico da ilha e por isso, qualquer painel interpretativo deverá sofrer deterioração rápida. No entanto, a mesma iniciativa sugerida para a pedra do Sino pode ser feita aqui: descansos de prato com informações simples sobre a formação da Cachoeira e da geologia local, como os distribuídos em alguns restaurantes de fast food quando veiculam curiosidades sobre os jogos olímpicos, a copa, ou fatos nutricionais.

Além disso, a venda de souvenirs, artesanato e do guia sugerido na seção 6.5.2 é propícia aqui, revertendo em receita para a OG.

\subsubsection{Praia da Figueira}

A Praia da Figueira é a única praia pertencente ao PElb. Apesar de bela e utilizada para mergulho, o acesso a ela não é fácil e se dá exclusivamente por barco, ou através de trilha local com duração de aproximadamente duas horas que sai da Praia de Castelhanos e passa pelas praias Mansa e Vermelha.

As informações mais importantes a serem veiculadas a respeito deste geossítio são a proveniência da alta quantidade de granada que causa a cor vermelha da areia e, mais importante, que a granada dessa areia não tem valor comercial, para evitar uma súbita disparada à praia em busca desse mineral.

Entretanto, devido às características de acesso e localização da praia, acreditamos que o melhor lugar para divulgar este geossítio seja através de um site ou do guia geológico já citado.

Outra possibilidade é haver um display, em algum outro lugar mais visitado de Ilhabela, como por exemplo, a Praia do Perequê, (onde se concentram as saídas de excursões, há prática de SUP e vários quiosques ao longo da orla). Neste display, de material transparente, pode haver uma amostra da rocha-fonte e amostra da 
areia da Praia da Figueira. A ele estariam conjugadas as informações já descritas acima e uma explicação sobre os processos de intemperismo, detalhando como foi possível, em um tempo prolongado, retirar os minerais da rocha e trabalhá-los de forma que ficassem redondos e brilhantes (pela ação da água) ou foscos (pela ação eólica).

\subsubsection{Praia de Enchovas}

Assim como a Praia da Figueira, o acesso à Praia de Enchovas não é fácil. Depende de barco, essencialmente, ou de trilha por terra que sai da Praia do Bonete, mas para a qual o acesso também é bastante demorado (4 a 6 hs de trilha por terra, ou acesso por barco).

A praia de Enchovas não é particularmente procurada por seu apelo estético; o geossítio foi designado por seu valor científico. Assim, não se vê motivo para alguma iniciativa interpretativa no local, como a instalação de um painel, por exemplo.

Entretanto, a exemplo dos outros geossítios, se houver a confecção de um guia geológico ou de um site, a interpretação de Enchovas necessariamente deve constar dele, pelo motivo principal o qual a inseriu neste inventário: o fato de que os seixos da zona de tormenta da praia representam a grande variedade de tipos litológicos da ilha.

\subsubsection{Buraco do Cação}

O acesso ao Buraco do Cação requer percorrer a parte inicial da Trilha do Bonete, na qual há uma subida razoavelmente íngreme e que pode ser penosa para quem não está habituado. Ao término desta subida (Morro do Cação), há a entrada para a trilha secundária que leva ao topo do Buraco do Cação e que é de dificuldade média.

As iniciativas de gestão neste geossítio requerem, em primeiro lugar, a sinalização apropriada da trilha, para evitar que 0 visitante se perca. 
Concomitantemente, é necessária a manutenção da trilha, cortando galhos e instalando degraus onde se fizer necessário - nos mesmos moldes do que é feito nas outras trilhas do PElb, para minimizar as chances de acidente - o local não é acessível por veículos automotivos, o que dificulta um eventual resgate.

Em um dos pontos da laje do Buraco do Cação aconselha-se a instalação de grades de proteção e de sinalização de aviso. Estima-se que, com a melhoria do acesso e a divulgação do local, o número de visitantes sofra um incremento, aumentando as chances de acidentes - uma queda, neste local, seria fatal. Não se pode esperar que a totalidade dos visitantes haja sempre com inefável bom senso, assim como não se pode excluir a possibilidade de algum visitante sofrer vertigem, estando mais próximo da borda do promontório.

Assim como no Pico do Baepi, o local não é propício para a instalação de painéis. Porém, muito próximo dali está a Fazenda da Laje e o Lago Dourado. Quem inicia a Trilha do Bonete, mas não pretende percorrê-la completamente, costuma visitar estes dois locais contíguos ao Buraco do Cação. A Fazenda da Laje apresenta-se como um excelente local para estabelecer um polo de interpretação, com venda de artesanato, manuais e mapas, bebidas, lanches e frutas, de modo a oferecer uma possibilidade de refazimento ao turista cansado, antes que ele percorra o caminho de volta. Além disso, este comércio pode reverter em benefício para a família que lá reside e para o PElb.

Outro local possível é o início da trilha, onde os visitantes que estão dirigindo deixam seus carros, antes da porteira, no estacionamento do "Seu Zé", que, além de proprietário deste local, é também um artista escultor de animais em cimento.

As iniciativas de interpretação devem contemplar a erosão diferencial que consumiu o dique e deixou a rocha alcalina. Outro ponto interessante é o fato de esta rocha não apresentar as caneluras, talvez devido aos processos já mencionados na descrição do geossítio.

\subsubsection{Diques da Ponta da Sela, Gabros Estratiformes e Praia do Portinho}

Estes geossítios foram selecionados pelo seu valor científico e não têm forte apelo turístico. O que têm em comum é o acesso a eles, que se dá cruzando propriedades privadas. 
É mandatório que haja consenso entre a $O G$ e os proprietários destes terrenos, no sentido de viabilizar a visita de pesquisadores e estudantes ao local. A OG pode estimular os proprietários a melhorarem as condições de acesso, abrindo trilhas/caminhos e fazendo a manutenção periódica delas, com remuneração ou incentivos fiscais.

No caso específico dos Diques da Ponta da Sela, o proprietário, Sr. André Venco, é totalmente favorável à visitação, tendo aberto a trilha que dá acesso ao costão por meios próprios. É um local belíssimo e tem grande potencial turístico, especialmente para atrair visitantes que procuram se distanciar com segurança da algazarra das praias, que é constante na alta temporada.

Estes três geossítios devem figurar nos manuais e nas descrições de um eventual site, pois são exemplos valiosos da geodiversidade de llhabela e ilustram eventos importantes da evolução geológica do local.

Quando o foco é um público mais leigo, ou estudantes dos primeiros semestres de cursos universitários da área, as explicações de como estes locais foram formados e de como os tipos litológicos se relacionam entre si necessitam de esquemas gráficos muito didáticos para serem claros. Uma empreitada bastante complexa, sem dúvida. No entanto, se houver recursos disponíveis, as animações gráficas são as ferramentas perfeitas para elucidar ao interessado como as forças tectônicas conseguem modificar tão profundamente a paisagem, fazendo as rochas colidirem, deformarem e intrudirem outras rochas.

Todavia, o uso pensado para estes geossítios é essencialmente científico e, em segundo lugar, didático a nível universitário. Adiciona-se o fato de ainda são necessários estudos mais profundos e pontuais sobre os três locais, e, em especial sobre o geossítio dos Gabros Estratiformes, sobre o qual não foi possível pesquisar pontualmente, somente fazer inferências seguindo evidências e constatações advindas de modelos de Petrologia Ígnea e outros estudos em áreas com assembleias litológicas semelhantes.

Vale ressaltar que o monitoramento de visitação e constantes vistorias são indicados, já que ainda é prática comum entre os profissionais das ciências da terra retirar amostras e martelar as rochas, mesmo sem um motivo definido. A cultura do "souvenir geológico" ainda é muito arraigada entre alunos dos cursos de ciências da Terra e se nada for feito para coibir esta prática, em algumas décadas os elementos 
geológicos que nos chamaram a atenção nestes geossítios podem ter desaparecido ou se descaracterizado.

Não se pretende aqui tolher a retirada de amostras para fins de estudo, o que iria contra o motivo principal pelo qual estes locais foram considerados geossítios de valor científico. Além do mais, a prática de campo e atividades relacionadas com a pesquisa deve ser aprovada pela Comissão Técnico-Científica do Instituto Florestal (COTEC), já que a ilha está praticamente toda coberta pela jurisprudência do Parque Estadual.

O que se pretende minimizar são os efeitos das "marteladas exaltadas de estudantes motivados", para evitar, por exemplo, a sina da Pedreira de Perus, um afloramento hectométrico pegmatítico com quartzo, biotita, turmalina, lepidolita, feldspato e eventuais minerais acessórios, em São Paulo, que era destino de saída de campo do curso de Sistema Terra, no curso de Geologia da USP, e, martelada à exaustão anualmente, hoje não existe mais como instrumento didático. 


\section{DISCUSSÃO E CONCLUSÕES}

\subsection{METODOLOGIA DO INVENTÁRIO}

A metodologia de conservação do patrimônio geológico compreende as etapas de inventário, quantificação (com subsequente classificação), conservação (com avaliação da vulnerabilidade, que pode ser feita, segundo alguns métodos, ainda na etapa de quantificação e, por isso, influir no resultado da classificação), valorização (que inclui a divulgação e a interpretação geológica) e monitoramento (com posteriores avaliações do seu estado de vulnerabilidade e do perfil de visitantes) (BRILHA, 2005).

No caso específico do litoral norte do estado de São Paulo, no que concerne à parte do inventário propriamente dito, o levantamento bibliográfico, que normalmente precede os trabalhos de campo e os direciona, é tolhido pelo número escasso de publicações, devido à dificuldade em acessar os afloramentos, (muitos estão cobertos pela mata atlântica ou são acessíveis somente por mar) e seu caráter descontínuo (GARCIA et al., 2014). Assim, é preciso inquirir outras fontes, como os pesquisadores que trabalham ou já trabalharam com a área, em primeiro lugar, e guias turísticos, monitores ambientais e moradores locais, em seguida. Essa configuração de fatores leva o pesquisador a fazer um trabalho de mapeamento, (implicando em maior uso de tempo e verbas), já que as informações são incompletas ou limitam-se a indicações um tanto vagas.

Neste trabalho, o inventário seguiu esta característica. Muitos pontos foram sugeridos por professores e alunos de pós-graduação da Universidade de São Paulo e por monitores e guardas do Parque Estadual de Ilhabela e outros foram conhecidos durante o trabalho de percorrer os costões em busca de locais de interesse geológico ou na tentativa de acessar outros pontos.

As indicações recebidas, quando não precedidas de referências bibliográficas, apresentam duas características peculiares: quando advém de pesquisadores, refletem acentuado interesse científico e quando de monitores, guardas florestais e moradores, destacado apelo estético.

Adicione-se a isso o fato de que muitos pesquisadores geólogos ainda não estão familiarizados com o conceito de patrimônio geológico e frequentemente o 
relacionam ao turismo e ao geoturismo. Assim, quando consultados, respondem que não conhecem nenhum ponto ou que os locais que conhecem "não são bons para visitação de turistas", "não são bonitos" ou "não são de fácil acesso". Por isso, tornase mais frutífero indagar os pesquisadores sobre "afloramentos importantes em sua pesquisa" ou "afloramentos os quais seus alunos visitam", além da consulta mandatória a roteiros de campo de disciplinas oferecidas nos cursos, que podem revelar muito.

No tocante à consulta feita a moradores, guias turísticos, monitores e guardas do parque, percebeu-se que o uso de adjetivos aliados às expressões "pedra" e "local com pedras" (pedra estranha/ grande/ legal/ bonita/ curiosa) nas perguntas pode render boas indicações, como foi o caso da Cachoeira do Gato ("uma parede grande de pedra com outra pedra preta colada nela"), Praia do Portinho ("várias pedras coloridas, uma em cima da outra") e do Buraco do Cação ("uma fenda enorme na pedra, por onde entra o mar").

Em llhabela, ainda foi grande o apelo das histórias folclóricas, que acabaram revelando locais de interesse para o geoturismo, a serem explorados em projetos futuros, que não constam neste inventário, por não possuírem interesse científico. Um exemplo (citado no cap.6 desta dissertação) é o Lago Dourado, cujas águas brilham com a incidência da luz solar devido às partículas de vermiculita em suspensão e que é correlacionado à lenda da Feiticeira.

\subsection{OS GEOSSÍTIOS}

A escolha de oito dos nove geossítios que compõem este inventário seguiu o framework de história geológica da região costeira do estado de São Paulo, no contexto da evolução geotectônica do Supercontinente Gondwana (essencialmente - Terreno Costeiro, além de rochas magmáticas do Orógeno Araçuaí e o magmatismo alcalino meso-cenozóico) e foi conduzida sob o crivo do valor científico. Somente um geossítio, a Pedra do Sino, não obedeceu exatamente a estes parâmetros: é um afloramento de blocos rolados, sendo alguns deles, fonolitos. Seu conhecido apelo turístico e suas características sonoras, que incitam a curiosidade de muitos visitantes e que estão intrinsicamente ligadas à geologia, não puderam ser olvidados. 


\begin{tabular}{|c|c|c|c|c|}
\hline Geossítio & Valor & Ilustra & Usos & Adicional \\
\hline Pedra do Sino & $\begin{array}{l}\text { Ígneo } \\
\text { Geomorfológico }\end{array}$ & $\begin{array}{l}\text { Magmatismo alcalino } \\
\text { Processos de intemperismo }\end{array}$ & $\begin{array}{l}\text { Turístico } \\
\text { Didático }\end{array}$ & $\begin{array}{l}\text { Presença } \\
\text { de } \\
\text { fonolitos }\end{array}$ \\
\hline Pico do Baepi & $\begin{array}{l}\text { Geomorfológico } \\
\text { Tectônico }\end{array}$ & $\begin{array}{l}\text { Magmatismo alcalino } \\
\text { Evolução da Serra do Mar } \\
\text { Dinâmicas sedimentares das } \\
\text { encostas da Serra do Mar }\end{array}$ & $\begin{array}{l}\text { Turístico } \\
\text { Didático }\end{array}$ & \\
\hline $\begin{array}{l}\text { Cachoeira do } \\
\text { Gato }\end{array}$ & $\begin{array}{l}\text { Ígneo } \\
\text { Tectônico/estrutural } \\
\text { Geomorfológico }\end{array}$ & $\begin{array}{l}\text { Magmatismo alcalino } \\
\text { Magmatismo básico (diques) } \\
\text { Intemperismo (erosão } \\
\text { diferencial) }\end{array}$ & $\begin{array}{l}\text { Turístico } \\
\text { Científico } \\
\text { Didático }\end{array}$ & \\
\hline $\begin{array}{l}\text { Praia da } \\
\text { Figueira }\end{array}$ & Sedimentar & $\begin{array}{l}\text { Processos de intemperismo } \\
\text { Dinâmica sedimentar }\end{array}$ & $\begin{array}{l}\text { Turístico } \\
\text { Científico } \\
\text { Didático }\end{array}$ & $\begin{array}{l}\text { Areias } \\
\text { vermelhas } \\
\text { (presença } \\
\text { de } \\
\text { granada) }\end{array}$ \\
\hline $\begin{array}{l}\text { Praia de } \\
\text { Enchovas }\end{array}$ & $\begin{array}{l}\text { Ígneo } \\
\text { Tectônico/estrutural } \\
\text { Sedimentar } \\
\text { Geomorfológico }\end{array}$ & $\begin{array}{l}\text { Abertura do Atlântico Sul } \\
\text { Dinâmica sedimentar } \\
\text { Estruturação da Faixa Ribeira } \\
\text { durante a formação do } \\
\text { Gondwana }\end{array}$ & $\begin{array}{l}\text { Científico } \\
\text { Didático }\end{array}$ & \\
\hline $\begin{array}{l}\text { Buraco do } \\
\text { Cação }\end{array}$ & $\begin{array}{l}\text { Ígneo } \\
\text { Tectônico/estrutural } \\
\text { Geomorfológico }\end{array}$ & $\begin{array}{l}\text { Magmatismo alcalino } \\
\text { Magmatismo básico (diques) } \\
\text { Intemperismo (erosão } \\
\text { diferencial) }\end{array}$ & $\begin{array}{l}\text { Turístico } \\
\text { Científico } \\
\text { Didático }\end{array}$ & \\
\hline $\begin{array}{l}\text { Diques da } \\
\text { Ponta da Sela }\end{array}$ & $\begin{array}{l}\text { Ígneo } \\
\text { Tectônico/estrutural }\end{array}$ & $\begin{array}{l}\text { Abertura do Atlântico Sul } \\
\text { (intrusão de diques básicos e } \\
\text { lamprófiros) }\end{array}$ & $\begin{array}{l}\text { Turístico } \\
\text { Científico } \\
\text { Didático }\end{array}$ & \\
\hline $\begin{array}{l}\text { Gabros } \\
\text { estratiformes }\end{array}$ & $\begin{array}{l}\text { Ígneo } \\
\text { Tectônico/estrutural }\end{array}$ & $\begin{array}{l}\text { Processos ígneos (câmara } \\
\text { magmática) } \\
\text { Magmatismo alcalino } \\
\text { (possivelmente) } \\
\text { Magmatismo básico (diques) }\end{array}$ & $\begin{array}{l}\text { Científico } \\
\text { Didático }\end{array}$ & $\begin{array}{l}\text { Relações } \\
\text { de } \\
\text { contato } \\
\text { entre os } \\
\text { litotipos }\end{array}$ \\
\hline $\begin{array}{l}\text { Praia do } \\
\text { Portinho }\end{array}$ & $\begin{array}{l}\text { Ígneo } \\
\text { Metamórfico } \\
\text { Tectônico/estrutural }\end{array}$ & $\begin{array}{l}\text { Tectônica (amalgamação do } \\
\text { Gondwana) }\end{array}$ & $\begin{array}{l}\text { Científico } \\
\text { Didático }\end{array}$ & $\begin{array}{l}\text { Relações } \\
\text { de } \\
\text { contato } \\
\text { entre os } \\
\text { litotipos }\end{array}$ \\
\hline
\end{tabular}

Tabela 7.2 - Os geossítios de llhabela, os valores de cada um, quais processos ou eventos geológicos importantes ilustram e as eventuais características adicionais que agregam valor e interesse a eles. 
Neste contexto, foram levantados locais que ilustram processos anteriores ou concomitantes à amalgamação e ao desenvolvimento do supercontinente Gondwana, às fases da abertura do Atlântico Sul e a processos posteriores, mais recentes, que resultaram na geomorfologia que a área apresenta. Os geossítios e os valores e usos a eles atribuídos são apresentados na tabela 7.2.

\subsection{O PROCESSO DE QUANTIFICAÇÃO}

A quantificação dos geossítios é necessária para estabelecer a classificação e a prioridade de proteção, de modo a proceder à implementação de medidas de conservação. Embora o número de geossítios seja pequeno (nove), a quantificação foi feita para auxiliar na comparação entre eles e na seriação de outros geossítios constantes dos trabalhos de inventário concomitantes a este (em fase de elaboração ${ }^{1}$ ) e que englobam outros municípios da região.

Para tal, foram utilizados o método de Brilha (2005) e a plataforma Geossit, do Serviço Geológico do Brasil (CPRM) e que se baseia nos métodos de Brilha (2005) e de Garcia-Cortés \& Carcavilla Urqui (2009).

A seguir, serão apresentadas as dificuldades e características da aplicação de ambos os métodos para o contexto deste trabalho.

\subsubsection{Método de Brilha (2005)}

Este método apresenta os critérios A (intrínsecos ao geossítio), B (uso do geossítio) e C (necessidade de proteção). Cada critério tem parâmetros, os quais apresentam alternativas para descrever a situação do geossítio. Alguns parâmetros exibem três alternativas, outros, cinco. Cada alternativa tem a ela um valor atribuído.

1SANTOS, P.L.A. Patrimônio Geológico em áreas de proteção ambiental: Ubatuba-SP. Mestrado (início: 2012).

REVERTE, F. C. Avaliação da geodiversidade em São Sebastião-SP como patrimônio geológico. Mestrado (início: 2012).

ARRUDA, K.E.C. A Geodiversidade do Litoral Norte de São Paulo. Doutorado (início: 2013),

O patrimônio geológico do litoral norte do estado de SP: proposta de geoconservação. Projeto FAPESP, pesquisador responsável: $\operatorname{Prof}^{\mathrm{a}} \operatorname{Dr}^{\mathrm{a}}$ Maria da Glória Motta Garcia. 
Os valores dos parâmetros variam de 1 a 5 . O critério A tem nove parâmetros; $B$ apresenta sete e $\mathrm{C}$, seis parâmetros.

$\mathrm{Na}$ seção A, (critérios intrínsecos ao geossítio), o parâmetro A3 (grau de conhecimento científico) não contempla os trabalhos finais de graduação de cursos de Geologia, comumente chamados de TF ou TG. É prática corrente no Brasil a confecção destes trabalhos e, ao menos na Universidade de São Paulo, o nível de exigência acadêmica tem se mostrado cada vez maior e produzido resultados sérios e confiáveis. Muitas vezes, são seguidos de publicação de artigo em revista nacional. Para o inventário de llhabela foram consultados alguns trabalhos desta categoria, que trouxeram informações relevantes e bem embasadas.

No parâmetro A8 (associação com outros elementos do meio natural) a dificuldade foi decorrente do fato de que o território brasileiro e, especialmente a área coberta por este inventário, exibem grande diversidade de espécies de fauna e flora que não estão restritas unicamente ao geossítio quantificado. Como os geossítios estão localizados próximos uns dos outros, na mesma ilha, um geossítio sozinho não é o habitat único da espécie endêmica da região, o cururuá. Além disso, há sua riqueza de espécies marítimas, característica que faz a ilha ser um local apreciado por mergulhadores.

Por isso, foi necessário fazer a escolha de prioridades entre duas alternativas, pois há uma única espécie de grande interesse (endêmica), mas a fauna e flora também são notáveis por sua abundância, embora, no geral, apresentem interesse moderado. Assim, entende-se que este é um ponto bastante subjetivo, onde o avaliador que seja conhecedor da biodiversidade amazônica, por exemplo, avalia a biodiversidade em llhabela como de interesse moderado. A pergunta que sobressai é: seria possível determinar uma escala de valores de biodiversidade em um inventário de geodiversidade? Seria necessário? Como aquilatar "interesse" e "abundância" em relação à biodiversidade nas alternativas do parâmetro "associação a outros elementos do meio natural"?

Quanto aos critérios relacionados ao uso do geossítio, a primeira dificuldade encontrada foi o parâmetro $\mathrm{B} 4$, relacionado com a acessibilidade. A situação de acesso aos geossítios de Ilhabela é variada, mas apresenta pelo menos dois fatores não contemplados nas alternativas: acesso exclusivo por trilha em mata (não transitável por automóvel) e acesso exclusivo por barco. É claro que a acessibilidade 
difícil reduz a possibilidade de uso do geossítio. Desse modo, estas duas alternativas poderiam ser contempladas em uma única alternativa geral, que ainda assim, diferiria muito da alternativa de menor valor nesta quantificação, que diz: "o geossítio localiza-se a mais de $1 \mathrm{~km}$ de algum caminho utilizável por veículos automóveis".

Neste ponto cabe o raciocínio de que o inventário foi feito no sentido de levantar geossítios de interesse científico, pelos quais os maiores interessados são geralmente alunos e pesquisadores das áreas ambientais e de ciências biológicas e da Terra, acostumados a percorrer caminhos longos, trilhas dentro da mata, terrenos acidentados, etc. Não somente esse perfil, mas também os praticantes de esportes radicais, que proliferam no país, estão acostumados a se locomover em ambientes como os acima descritos. As alternativas que descrevem o acesso não contemplam um usuário alternativo de perfil em crescimento no Brasil.

A maior discussão sobre os parâmetros deste critério, no entanto, residem no item "B7. Condições socioeconômicas". Das três alternativas, a de maior valor é aquela que retrata uma situação onde "os níveis de rendimento per capita e de educação são superiores à média nacional e a taxa de desemprego é menor". Traduzindo estes índices em IDH, entende-se que um geossítio terá maior potencial de uso quanto maior for o índice da população do local onde ele está. No entanto, é sabido que geralmente os locais onde a população apresenta um índice de IDH maior, o comércio e o setor de produtos oferta valores acima da média do mercado também. Por isso, o potencial de uso do geossítio pode ser prejudicado. Algumas pessoas costumam fazer passeios e levar seus próprios lanches. Ainda assim, a oferta de infraestrutura com venda de alimentos é um grande chamariz de visitação, a não ser que os preços sejam muito altos. Neste caso, a taxa de visitação pode cair.

Finalmente, os critérios relacionados com a necessidade de proteção do geossítio $(C)$ trazem alternativas para seus seis parâmetros que, se por um lado não contemplam diretamente a realidade brasileira, por outro trazem definições que possibilitam ao avaliador encontrar rapidamente os equivalentes no Brasil (por exemplo, C4, que traz o valor do metro quadrado do terreno em euros).

É importante mencionar que, apesar de a constituição brasileira, no artigo 20, inciso IV (BRASIL, 1988) declarar que praias marítimas são bens pertencentes à 
União, foi decidido considerar os geossítios que se encontram no costão ou na praia como parcialmente públicos e parcialmente privados quando o acesso a eles se dá unicamente através de propriedade privada.

\subsubsection{Geossit}

O sistema é mais complexo do que o método de Brilha, pois além dos critérios A (ao qual adicionou o parâmetro A10), B (com mais dois parâmetros, B8 e B9) e C (com a adição de um parâmetro, C7), exibem um critério extra, a vulnerabilidade $\mathrm{V}$. Os parâmetros extras em A, B e C e os de V foram inspirados em parâmetros do método de Garcia-Cortés \& Carcavilla Urqui (2009). Cada parâmetro de V recebe um peso diferente.

Alguns parâmetros de A, B e C são utilizados para calcular os interesses científico (Ic), didático (Id) e turístico (It) dos geossítios. Para tal, os mesmos parâmetros recebem pesos diferentes em cada interesse. No final, a média aritmética dos três tipos de interesse resulta no interesse global (lg) que, somado à vulnerabilidade $\mathrm{V}$, fornece a prioridade de proteção (PP).

A primeira observação sobre a vulnerabilidade é no parâmetro "interesse mineiro", que é uma herança de forte característica espanhola e que faz sentido no Brasil especialmente em locais onde há este tipo de atividade econômica. No entanto, este parâmetro é computado duas vezes: em C (necessidade de proteção) e novamente em V, onde tem o peso mais alto, 15. Em Ilhabela, este parâmetro não faz sentido e, por isso, recebe o valor zero em ambas as ocorrências.

Ainda em V, as alternativas para "regime de proteção local" não contemplam a situação deste projeto. O mais próximo é "local com figura de proteção, porém não sujeito a plano de ordenamento e sem vigilância", de valor 1 . Sem dúvida, não é o que ocorre dentro dos limites do PElb. No entanto, a outra alternativa é "não se aplica", com valor zero. Optou-se por aquela de valor 1 .

Quanto à "proteção física ou indireta", as alternativas não contemplam os locais para os quais o acesso é mais complicado, como no caso de trilhas de nível médio ou difícil. Para estes casos, selecionou-se "não se aplica", porque se entende 
que sejam equivalentes, ou seja, o acesso complicado é um modo de proteção física.

As alternativas referentes ao parâmetro "regime de propriedade local" parecem se contradizer quanto ao seu objetivo. Entende-se que quanto mais alto 0 valor de V, mais vulnerável é o geossítio e, por isso, precisa de maior proteção. Dessa forma, o valor mais alto deveria ser "propriedade pública com acesso livre" (valor 2 na realidade), ao passo que "propriedade privada com acesso restrito" recebe valor 4 .

Nas seções A, B e C também foi necessário fazer adaptações de interpretação. As aferições mais relevantes são:

- A3 (grau de conhecimento científico) - trabalhos de graduação foram considerados equivalentes a resumos de congressos, por terem sido sujeitos a crivo científico e terem menor abrangência que artigos de revistas;

- B7 (condições socioeconômicas) - enquanto o método de Brilha compara a renda do local à do país, o Geossit compara à média estadual. No caso de São Paulo, especificamente, os resultados mudam, pois o IDH médio do estado é mais alto que o do país. Na realidade brasileira, faz mais sentido a comparação à média do estado, devido às dimensões territoriais;

- C1 (ameaças atuais ou potenciais) - nenhuma das alternativas correspondeu à situação de um geossítio como a Pedra do Sino, por exemplo. Neste caso, optou-se por aquela que fosse menos distante do real. Porém, é preciso desenvolver alternativas para abranger locais que apresentam infraestrutura, estão relativamente próximos a um local que está recebendo forte implementação urbanística (o porto de São Sebastião) e que, não são protegidos por nenhuma lei específica, apesar de pertencer à União;

- C5 (regime de propriedade) repete o problema ocorrido no método anterior. A solução utilizada foi a mesma: considerou-se o local público cujo acesso se dá por propriedade privada como parcialmente público e parcialmente e privado.

- C7 (proximidade de áreas recreativas) - a localização de alguns geossítios está exatamente na praia. Contudo, praias como as de Enchova não são realmente locais de recreação no melhor sentido da palavra, pois o acesso a elas é difícil. Por isso, neste parâmetro, quantificou-se a Praia de Enchovas 
em relação à Praia do Bonete. Quanto à Praia da Figueira, apesar de seu acesso difícil, é destino turístico para a prática de mergulho e, por isso, foi considerada como local recreativo.

\subsubsection{Resultados das quantificações}

Os resultados obtidos com cada um dos métodos diferiram bastante. $O$ método de Brilha indica o geossítio dos Diques da Ponta da Sela, seguido pelos geossítios dos Gabros Estratiformes e da Praia de Enchovas, empatados em segundo lugar, e a Praia da Figueira em terceiro. Os cálculos de quantificação feitos pelo Geossit apresentam em primeiro, segundo e terceiro lugares a Pedra do Sino, a Praia do Portinho e os Diques da Ponta da Sela, respectivamente. A Pedra do Sino é um local que foi incluído ao inventário por seu alto valor turístico, (pois é um afloramento de blocos rolados e não in situ), e, por isso, incluir-se-á nesta análise o quarto lugar, o geossítio dos Gabros Estratiformes.

Em nenhum dos dois métodos os geossítios alcançaram relevância nacional ou internacional. No método de Brilha, isso se deu porque, de todos os parâmetros responsáveis por indicar esta relevância, os geossítios não contemplaram as condições pressupostas para A3 (constar em pelo menos um artigo publicado em revista internacional ou quatro artigos publicados em revistas nacionais) e A6 (ser um local-tipo na área de análise).

No Geossit, os geossítios também não contemplaram os mesmos parâmetros A3 e A6. Vale notar, no entanto, que as condições para relevância nacional e internacional sofreram alterações: em A3, o mínimo necessário para ter relevância nacional é o geossítio constar de uma dissertação de mestrado ou de um artigo em revista nacional com corpo editorial (tanto para relevância nacional quanto internacional). Em A6, o geossítio deve ser reconhecido como local-tipo para ter relevância internacional, ou ao menos como local-tipo secundário, para relevância nacional. Nenhuma das condições foi satisfeita.

Analisando os resultados parciais, percebe-se que os valores de vulnerabilidade calculados separadamente no Geossit e depois adicionados aos valores parciais de interesses científico, didático e turístico, influíram 
consideravelmente na classificação final. Os geossítios mais vulneráveis são, em ordem decrescente, a Pedra do Sino, os Diques da Ponta da Sela e a Praia do Portinho. Esse cálculo não ocorre no método de Brilha.

Comparando-se os resultados parciais de A, B e C, (gráficos 7.3.3a/b/c), . observa-se pouca variação de valores de $A$ (características intrínsecas) entre os dois métodos. Em B (uso potencial), há diferenças que chegam a quatro pontos, sendo os valores obtidos no Geossit maiores do que em Brilha, exceto para o geossítio da Pedra do Sino. Isso ocorre devido à adição dos dois parâmetros no Geossit, B8 e $B 9$, no critério $B$, além daqueles advindos do método de Brilha: utilização didática (B8) e conteúdo divulgativo (B9), os quais pontuaram a Pedra do Sino muito acima de todos os outros.
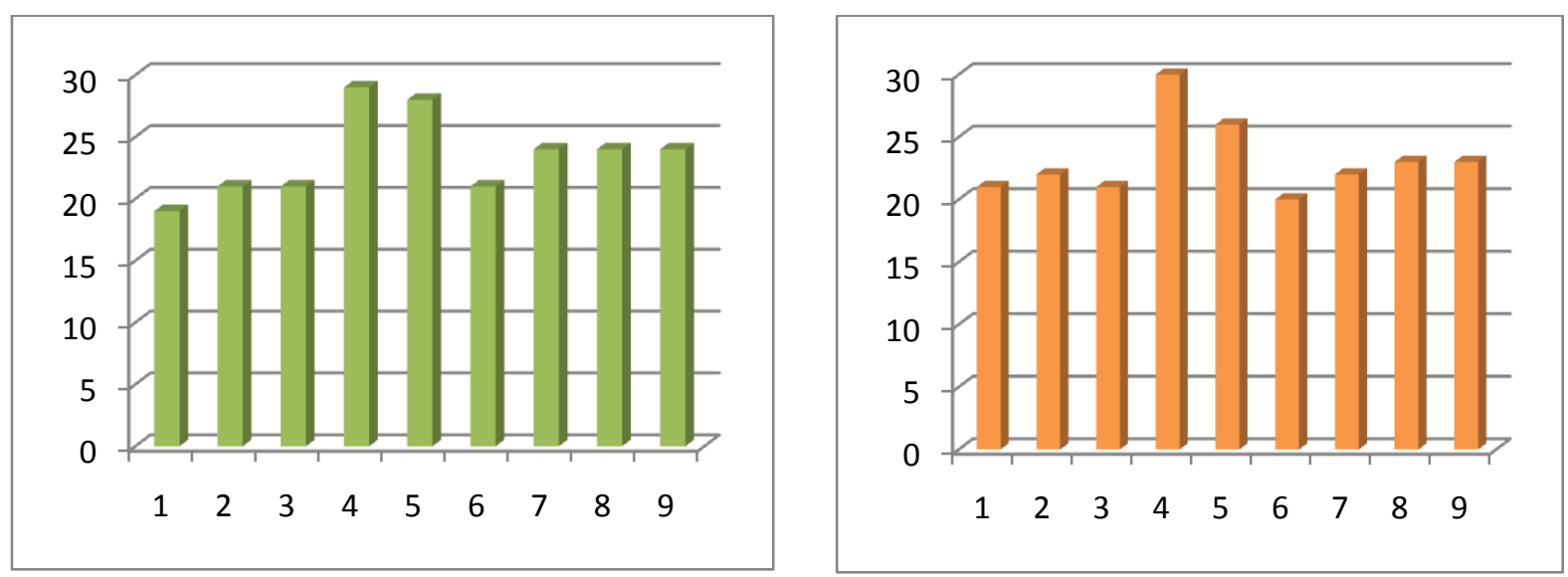

Gráfico 7.3.3a - Resultados da quantificação dos critérios A, características intrínsecas dos geossítios, no método de Brilha (2005), à esquerda e no Geossit, à direita.
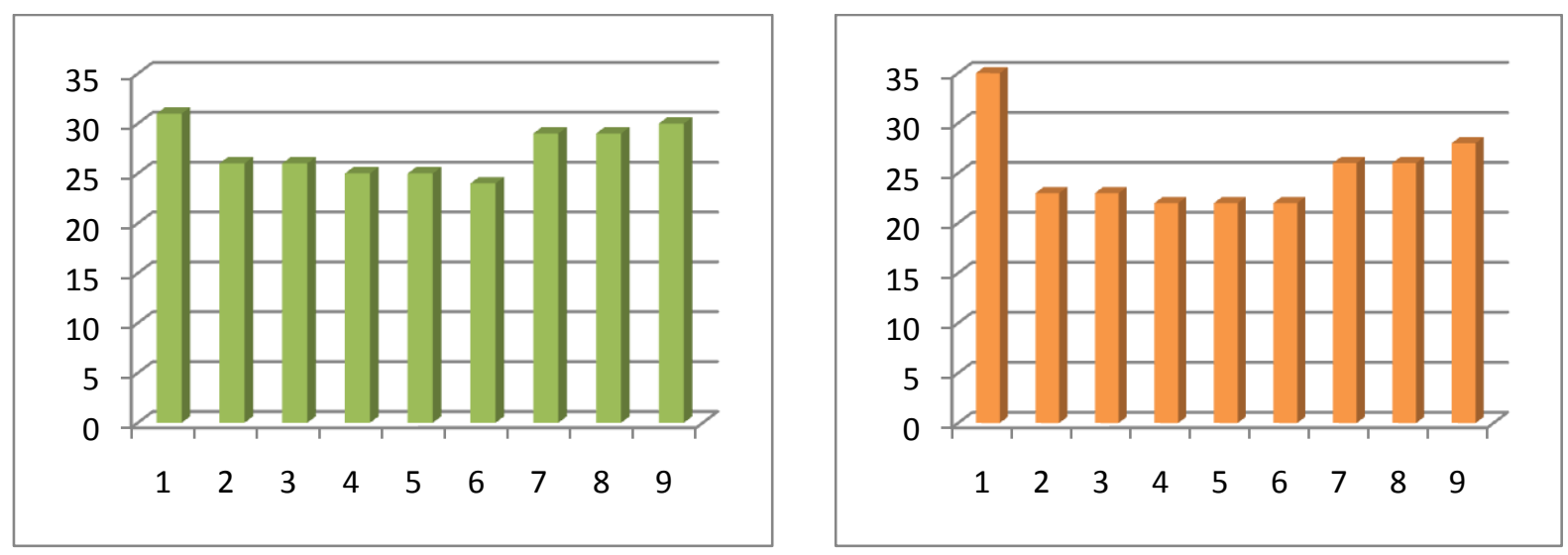

Gráfico 7.3.3b - Resultados da quantificação dos critérios B, uso potencial dos geossítios, no método de Brilha (2005), à esquerda e no Geossit, à direita. 

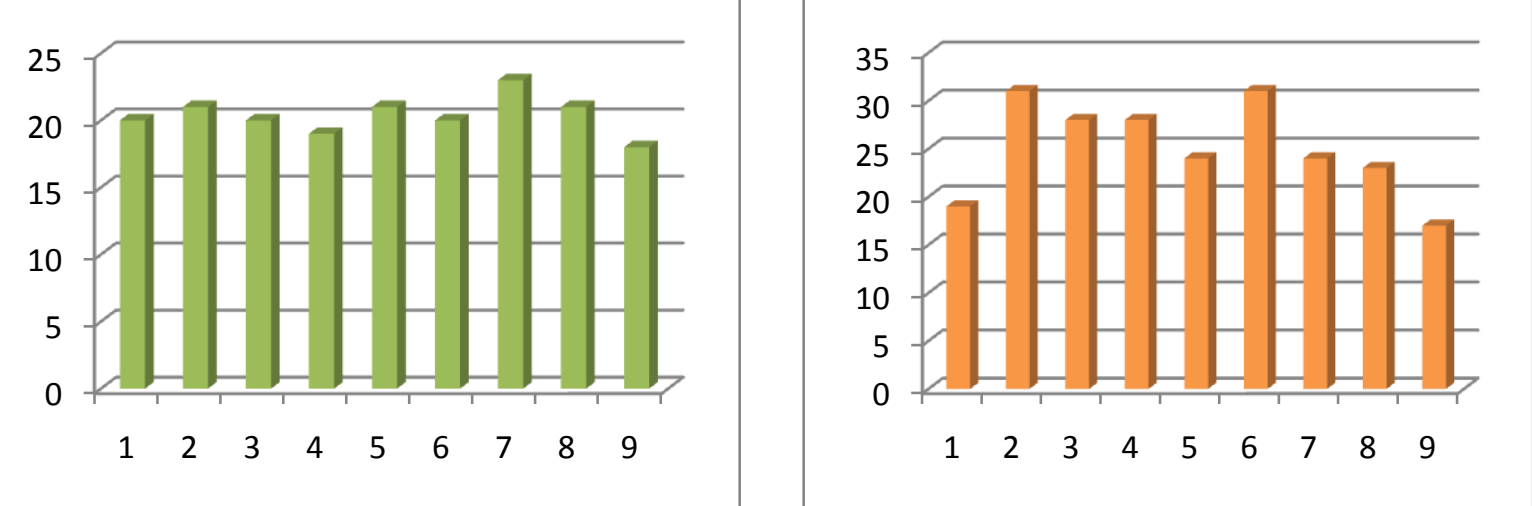

Gráfico 7.3.3c - Resultados da quantificação dos critérios C, necessidade de proteção dos geossítios, no método de Brilha (2005), à esquerda e no Geossit, à direita.

Em C, a adição do parâmetro $\mathrm{C7}$ no Geossit ("proximidade a áreas recreativas"), faz saltar os valores do Pico do Baepi e dos Diques da Ponta da Sela, justamente porque, estando as mais de $2 \mathrm{~km}$ de distância de praias, recebem pontuação maior do que os outros geossítios, que estão localizados em praias. Estas diferenças nos valores podem ser mais bem visualizadas nos gráficos 7.3.3a/b/c.

A vulnerabilidade, calculada separadamente, também fez os valores finais de prioridade de proteção do geossítio da Pedra do Sino alcançarem resultados maiores que os outros, especialmente devido ao parâmetro intitulado "proteção física ou indireta", (local de fácil acesso e sem proteção) colocando-o no topo da lista de prioridade, conforme se pode ver no gráfico 7.3.3d.

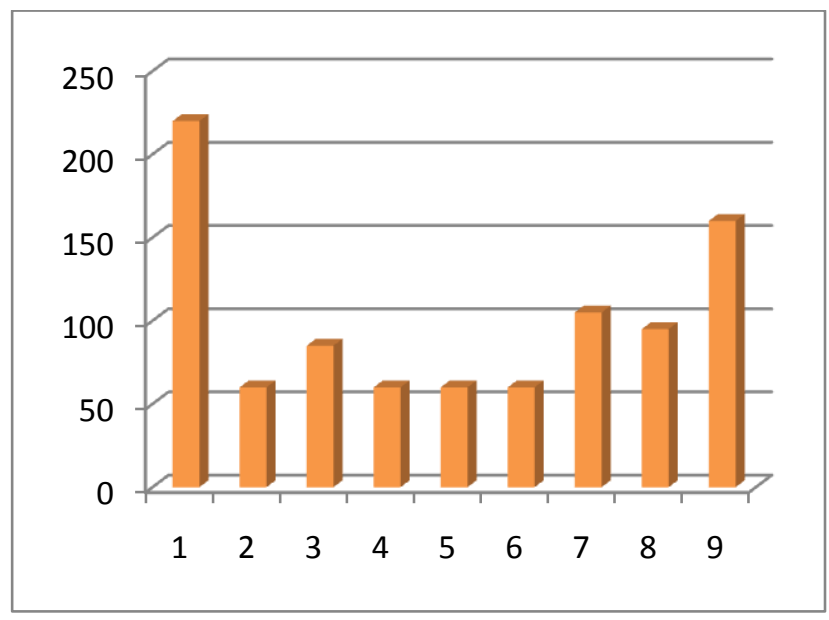

Gráfico 7.3.3d - Resultados da quantificação de vulnerabilidade dos geossítios no Geossit. 
No método de Brilha (2005), a vulnerabilidade é calculada uma vez, no critério C (necessidade de proteção). No Geossit ela é, de certa forma, duplicada, com alguns parâmetros repetidos, que figuram ao mesmo tempo em $\mathrm{C}$ e V (vulnerabilidade): "regime de propriedade", "interesse para a exploração mineral" e "proximidade de áreas recreativas.

Finalmente, o cálculo parcial de Ic, Id e It, com pesos diferentes para cada um dos parâmetros considerados, interferiu no resultado final de PP. Os mesmos B8 e B9, que privilegiaram a Pedra do Sino no cálculo de B, tiveram seus valores incrementados: $\mathrm{B} 8$, em interesse didático, com peso 20 e B9, com interesse turístico, com peso 15, conforme está projetado nos gráficos 7.3.3e/f/g.

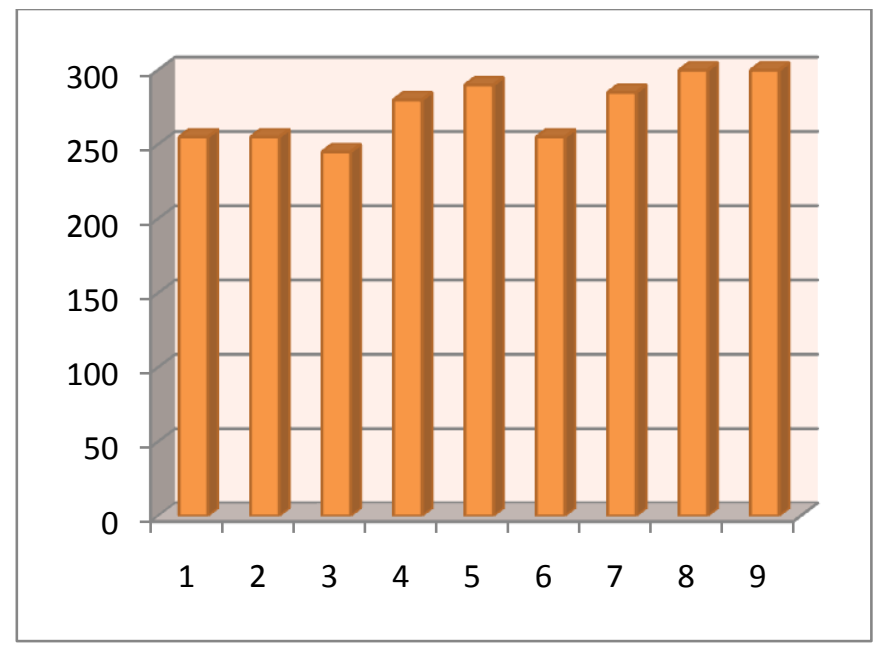

Gráfico 7.3.3e - Resultados da quantificação do interesse científico dos geossítios no Geossit.

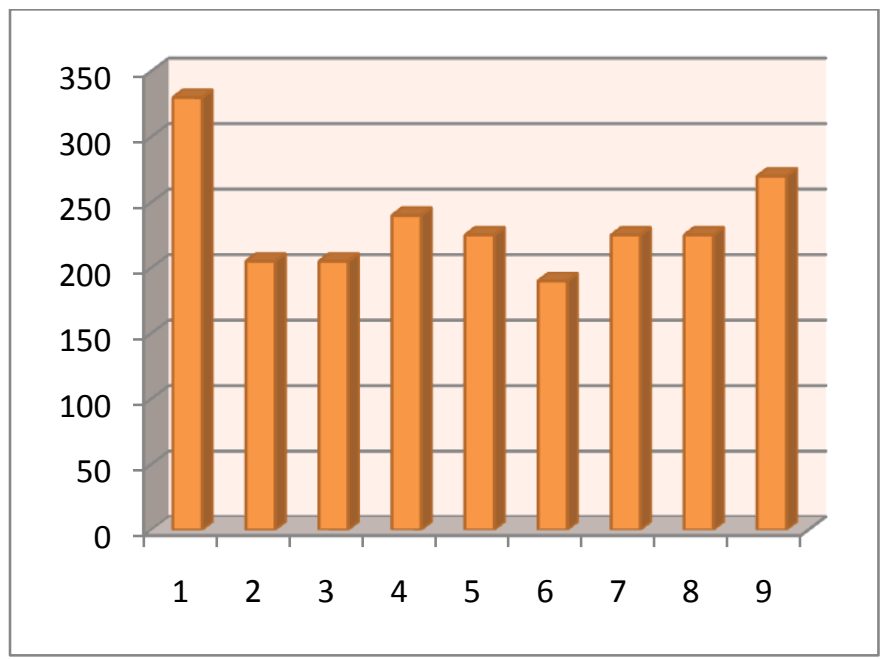

Gráfico 7.3.3f - Resultados da quantificação do interesse didático dos geossítios no Geossit. 


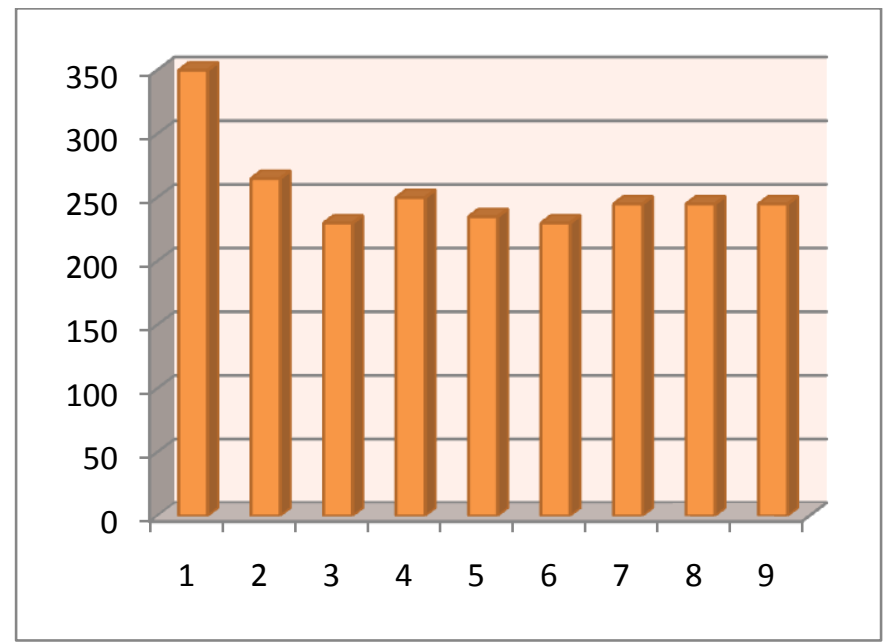

Gráfico 7.3.3g - Resultados da quantificação do interesse turístico dos geossítios no Geossit.

\subsubsection{Conclusões sobre a quantificação}

As alternativas oferecidas pelo Geossit, embora mais condizentes com a realidade brasileira do que os métodos desenvolvidos para os ambientes europeus nos quais foi embasado, ainda não contemplam o espaço estudado neste projeto, de praias, costões rochosos e locais remotos cujo acesso só é possível por trilhas ou por meios de locomoção alternativos, como barcos.

Ao se considerar os valores parciais didáticos e turísticos no cálculo de prioridade de proteção, (no Geossit) os geossítios que apresentam somente valor científico podem perder colocação na seriação, se não alcançarem vulnerabilidade $\mathrm{V}$ mais alta. Isto aconteceu com a Praia do Portinho, que alçou o segundo lugar justamente por apresentar vulnerabilidade de valor mais alto que os geossítios restantes.

Por outro lado, o método de Brilha (2005), cujos resultados priorizam os geossítios de maior valor científico nesta quantificação, necessita de várias adaptações na interpretação das alternativas dos parâmetros, de modo a serem aplicáveis neste contexto (conforme se pretendeu mostrar na seção 7.3.1).

Desse modo, conclui-se que os métodos de quantificação de patrimônio geológico requerem sua aplicação à exaustão, em vários ambientes contrastantes entre si, até que se encontrem as alternativas (para os parâmetros) que consigam 
englobar ao menos a maior parte das possibilidades de um território tão extenso e de ambientes variados quanto o brasileiro.

\subsection{GESTÃO E INTERPRETAÇÃO}

No cap.6 são apresentadas ideias para a gestão dos geossítios. A gestão do patrimônio geológico é etapa essencial da geoconservação, pois são as ações tomadas no sentido de monitorá-lo, protegê-lo e interpretá-lo que vão garantir a existência e, quando for o caso, o uso sustentável deste patrimônio por muito tempo.

Entre as sugestões de gestão, há as que englobam todos os geossítios ao mesmo tempo: páginas de sites na Internet com informações sobre a geologia, o acesso, a infraestrutura, as atividades que podem ser feitas no local e uma sessão especialmente pensada para os pesquisadores, onde podem encontrar sugestão de bibliografia e referências sobre o que já foi produzido cientificamente sobre a área; a confecção de um guia geológico com as mesmas informações do site e sugestões de roteiros geoturísticos autoguiados; a capacitação de guias turísticos, educadores e de representantes do setor terciário, nomeadamente o de prestação de serviços, (especialmente nos ramos da gastronomia, turismo e hotelaria) e artesanato.

Quanto às intervenções pontuais, para cada geossítio foram sugeridas iniciativas que abrangem desde a instalação de corrimãos e grades de segurança, em alguns locais, às ideias sobre a interpretação geológica, na forma de painéis, panfletos e mapas.

O fluxo turístico na região, de cerca de 100 mil visitantes na alta temporada (verão) ainda se concentra nas praias do litoral voltadas para o continente, que são servidas pela única rodovia asfaltada da ilha, a SP-131. As praias do sul, como Bonete e Enchovas, as praias ao norte como a da Fome e as do lado oceânico da ilha, como Figueira, têm acesso restrito, somente por barco, ou, no caso de Castelhanos e Jabaquara, por estradas de terra, (necessitando de veículos off-road para cruzá-las).

Há também uma enorme quantidade de cachoeiras e trilhas que podem ser visitadas, além dos geossítios aqui sugeridos. Algumas destas trilhas apresentam o percurso sinalizado pelo PElb e são de fácil trânsito. Porém, quando exibem algum 
tipo de interpretação, ela ainda se baseia fortemente na biodiversidade. Em alguns locais, o aspecto arqueológico tem sido valorizado, em grande parte por causa do trabalho da arqueóloga Cíntia Bendazzoli, que desenvolveu sua tese de doutorado sobre os sambaquis e as comunidades indígenas primitivas do local e que encabeça o Projeto de Gestão e Diagnóstico do Patrimônio Arqueológico de Ilhabela. Porém, o aspecto geológico ainda não foi citado em nenhum local.

As iniciativas de gestão da geodiversidade de Ilhabela se apresentam como uma possibilidade interessante de valorizar o geoturismo, na forma de percursos, destinos e atividades que não sejam totalmente dependentes das praias, cachoeiras e do mar, como acontece atualmente. Espera-se assim, que atraiam a visitação também fora de temporada, aliviando o ônus econômico que a população sofre com a grande disparidade de renda entre uma época e outra do ano.

\subsection{CONCLUSÕES GERAIS E PANORAMA FUTURO}

Os resultados obtidos por esta pesquisa, bem como as atividades que dela resultarem (especialmente na implementação das ideias de gestão, se ocorrer) são ainda expressões tímidas do que a região pode oferecer frente ao grande potencial geológico (e, consequentemente, geoturístico) que apresenta.

Acredita-se que maiores e mais prolongados estudos possam revelar outros locais de interesse geológico, além de resultados importantes no que concerne à petrogênese dos tipos litológicos dos afloramentos selecionados, às relações entre eles e ao esclarecimento dos processos relacionados ao magmatismo alcalino que ocorreu na região. Por isso, é importante que os locais selecionados sejam investigados cientificamente.

A contribuição de um trabalho de inventário como esse, (onde mapeamentos geológicos prévios não são detalhados e sobre o qual as publicações científicas são escassas), é considerável: revela locais de interesse geológico para investigação e pesquisa, sugere destinos didáticos universitários e incita ao desenvolvimento de novas metodologias ou à adaptação daquelas já existentes.

Além disso, os resultados deste trabalho fornecem dados acerca da relevância científica, da vulnerabilidade e das ameaças do patrimônio geológico de 
Ilhabela, bem como oferecem subsídios, tanto para os órgãos governamentais como para a sociedade civil, para que possam a implementar e executar iniciativas de gestão, no intuito de proteger a geodiversidade e, ao mesmo tempo, alavancar o desenvolvimento social da região.

Ademais, esta área é parte de um projeto maior de inventário do litoral do estado, o qual, quando finalizado, talvez ofereça as condições necessárias para o estabelecimento de um geoparque. Um geoparque, uma figura de gestão territorial, é embasado em três princípios: 1) geoconservação, 2) educação e pesquisa e 3) desenvolvimento social, especialmente através do geoturismo. Todavia, não é estritamente necessária a existência de um geoparque para que estes princípios sejam contemplados em ações administrativas, com as quais a região muito se beneficiaria desde já.

Com um planejamento geoturístico e implementos na gestão da geodiversidade, a região do litoral do estado de São Paulo pode, no futuro, ultrapassar o caráter de destino turístico sazonal e se tornar um local que ofereça atividades em todas as épocas do ano e que incluam a preservação e a educação ambientais.

Enquanto isto não ocorre, pode-se pensar em llhabela como um local possível para iniciar as primeiras providências em relação ao uso sustentável da geodiversidade (e, por conseguinte, da biodiversidade, já que são interdependentes). Com a finalização das outras partes do inventário, estas iniciativas, tendo sido postas em prática em Ilhabela, poderão ser estendidas às localidades adjacentes que, sendo tão esteticamente atraentes quanto a ilha, recebem todos os anos centenas de milhares de turistas e arcam com os impactos ambientais produzidos por esta atividade. 


\section{REFERÊNCIAS}

AB'SABER, A. N. Fundamentos da geomorfologia costeira do Brasil atlântico inter e subtropical. Revista Brasileira de Geomorfologia, UGB/UFU Uberlândia, v.1, p. 2743, 2000.

ABRANTES, P.C.C. Imagens de natureza, imagens de ciência. Campinas: Papirus, 1998, 248pp.

ALMEIDA F.F.M. Origem e evolução da plataforma brasileira. Rio de Janeiro, DNPMDGM, Boletim, v.241, p. 5 - 36, 1967.

ALMEIDA, F.F.M. Diferenciação tectônica da plataforma brasileira. In: Anais do Congresso Brasileiro de Geologia. Salvador, v.23, p. 29-46, 1969.

ALMEIDA, F.F.M.; AMARAL, G.; CORDANI, U.G.; KAWASHITA, K., The Precambrian evolution of the South American Catronic Margin South of Amazon River. In: NAIRN \& STELLI, (Eds.) The Ocean Basin and Margins, Nova York: Plenum, v.1, p.411-446, 1973.

ALMEIDA, F. F. M. The system of continental rifts bordering the Santos Basin. An. Acad. Bras. Ci., Rio de Janeiro, v.48 (suplemento), p.15-26, 1976.

ALMEIDA, F.F.M. Províncias estruturais brasileiras. In: Atas do VIII Simpósio de Geologia do Nordeste. Campina Grande, v.8, p. 363 - 391, 1977.

ALMEIDA, F.F.M. Relações tectônicas das rochas alcalinas mesozoicas na região meridional da Plataforma Sul-Americana. Rev. Bras. Geoc., v. 13, p. 139-158, 1983.

ALMEIDA, F.F.M. Distribuição regional e relações tectônicas do magmatismo pós-paleozóico no Brasil. Revista Brasileira de Geociências, v.16, n.4, p. 325-349, 1986.

ALMEIDA, F.F.M.; CARNEIRO, C.R. Origem e evolução da Serra do Mar. Revista Brasileira de Geociências, v.28, n.2, p.135-150, 1998.

ALVES, F.R. Contribuição ao conhecimento geológico e petrográfico das rochas alcalinas da llha dos Búzios, SP. 1997. 274f. Tese de doutorado. Instituto de Geociências, USP, São Paulo, 1997.

AMARAL, G; CORDANI, U.G.; KAWASHITA K.; REYNOLDS, J.H. Potassium-Argon dates of basaltic rocks from southern Brazil. Geochemical et Cosmochemical Acta, v.30, n.2, p. 159-189, 1966.

AMARAL, G.; BUSHEE, J.; CORDANI, U.G.; KAWASHITA, K.; REYNOLDS, J.H. Potassium-argon ages of alkaline rocks from southern Brazil. Geochimica et Cosmochimica Acta, v. 31, p.117-142, 1967. 
ARAMAQUI, G.T. Estudo da composição e da granulometria nos sedimentos praiais de Ilhabela, litoral norte de São Paulo. 2013. 61f. Trabalho Conclusão de Curso. Escola de Artes, Ciências e Humanidades, Universidade de São Paulo, São Paulo, 2013.

AUGUSTO, T. Petrografia e quimismo mineral de rochas gábricas e sieníticas do Maciço de São Sebastião, llha de São Sebastião, SP. 2003. 50f. Trabalho de Conclusão de Curso, Instituto de Geociências USP, São Paulo, 2003.

BARRETO, G.S. Geologia e tectônica da porção oeste da llha de São Sebastião, SP e a comparação com as áreas continentais adjacentes. 2012. $65 \mathrm{f}$. Trabalho de Conclusão de Curso. Instituto de Geociências, Universidade de São Paulo, São Paulo, 2012.

BELLIENI, G.; MONTES-LAUAR, C.R.; DE MIN, A.; PICCIRILLO, E.M.; CAVAZZINI, G.; MELFI, A.J.; PACCA, I.G. Early and late cretaceous magmatism from São Sebastião Island (SE - Brazil): geochemistry and petrology. Geochimica Brasiliensis, v. 4 , n. 1 , p. $59-83,1990$.

BERNÁLDEZ, F.G. Invitación a la ecología humana. La adaptación afectiva al entorno. Madrid, Tecnos. 1985. 159 p.

BOCZKO, R. Conceitos de Astronomia. São Paulo: Edgard Blucher. 1984. 448p.

BRASIL. Constituição (1988). Constituição da República Federativa do Brasil. Brasília, DF: Senado, 1988.

BRILHA, J. Patrimônio Geológico e Geoconservação: a conservação da natureza na sua vertente geológica. Viseu: Palimage Editores, 2005. 190 p.

BRILHA, J. A importância dos Geoparques no ensino e divulgação das geociências. Geol. USP, Publ. espec., v.5, out. 2009.

BRUSCHI, V. M.; CENDRERO, A. Geosite Evaluation: Can We Measure Intangible Values? II Quaternario: Italian Journal of Quaternary Sciences, v.18, p. 293-306, 2005.

BUREK, C.V.; PROSSER, C.D. (Ed.) The history of geoconservation. London: Geological Society, Special publications, v. 300, p. 1-5, 2008.

CALLICOTT, J. B. Beyond the land ethic: more essays in environmental philosophy. NY: State University of New York Press, 1999. 427p.

CARCAVILLA URQUÍ, L.; MARTÍNEZ, J.L.; VALSERO, J.J.D. Patrimonio geológico y geodiversidad: investigación, conservación, gestión y relación com los espacios naturales protegidos. Instituto Geologico y Minero de España. Cuadernos Del Museo Geominero, v.7, 2007. 
CORATZA, P.; GIUSTI, C. Methodological proposal for the assessment of the Scientific Quality of Geomorphosites. I/ Quaternario: Italian Journal of Quaternary Sciences. Volume Speciale, v.18, n.1, p. 307-313, 2005.

COUTINHO, J.M.V. Dyke swarms of the Paraná Triple Junction, southern Brazil. Revista do Instituto de Geociências- USP Serie Científica, São Paulo, v. 8, n. 2, p. 29-52, 2008.

CPRM. Mapa geodiversidade do Brasil. Escala 1:2.500.000. Legenda expandida. Brasília: CPRM/Serviço Geológico do Brasil, 2006. 68 p. CD-ROM.

CRAWFORD, K.R.; BLACK, R. Visitor Understanding of the Geodiversity and the Geoconservation Value of the Giant's Causeway World Heritage Site, Northern Ireland. Geoheritage, v. 4, p.115-126, 2012.

DANTAS, J.R.A. Mapa geológico do Estado de Pernambuco. Recife: DNPM, 1980. 112p. 2 mapas.

DELGADO, I. M.; SOUZA, J. D.; SILVA, L. C.; SILVEIRA FILHO, N. C.; SANTOS, R. A.; PEDREIRA, A. J.; GUIMARÃES, J. T.; ANGELIM, L. A. A.; VASCONCELOS, A. M; GOMES, I. P.; LACERDA FILHO, J. V.; VALENTE; C. R.; PERROTTA, M. M.; HEINECK, C. A. Geotectônica do Escudo Atlântico. In: BIZZI, L. A.; SCHOBBENHAUS, C.; VIDOTTI, R. M.; GONÇALVES, J. H. (Eds.): Geologia, Tectônica e Recursos Minerais do Brasil. CPRM, Brasília. 2003. 692p.

DIAS, G.; BRILHA, J. Raising public awareness of geological heritage: a set of initiatives. In: PARKES, M.A. (Ed.). Natural and Cultural Landscapes. The Geological Foundation. Dublin: Royal Irish Academy, p. 235-238, 2004.

DIAS NETO, C.M. Evolução tecno-termal do Complexo Costeiro (Faixa de dobramentos Ribeira) em São Paulo. 2001. 160 f. Tese de Doutoramento. IGc-USP. 2001.

DIAS NETO, C. M.; FONSECA, P. E.; MUNHÁ, J.; EGYDIO SILVA, M.; RIBEIRO, A. A estrutura em flor (flower structure) do Complexo Costeiro (Faixa Ribeira) em São Sebastião (São Paulo, Brasil). Cadernos Laboratório Xeolóxico de Laxe, La Curuña, v. 31, p. 105-125, 2006.

EBERHARD, R. (Ed.) Pattern \& process: towards a regional approach to national estate assessment of geodiversity. Canberra: Australian Heritage Comission, 1997. $102 p$.

EBERT, H.D.; HASUI, Y. Transpresional tectonics and strain partitioning during oblique collision between three plates in the Precambrian of southeast Brazil. In: HOLDSWORTH, R.E.; STRACHAN, R.A.; DEWEY, J.F. (Eds.) Continental transpressional and transtensional tectonics. London: Geological Society of London, v.135, p. 231-252, 1998. 
ENRICH, G.E.R. Petrogênese da suíte alcalina da llha Monte de Trigo, SP. 2005. $229 f$ e anexo. Tese de doutorado, Instituto de Geociências, USP, São Paulo, 2005. EOL - Encyclopedia of Life. Disponível em: http://eol.org/ . Acesso em 18 nov. 2012

FREITAS, R.O. Geologia e petrologia da Ilha de São Sebastião. São Paulo: F.F.C.L. (Fac. Fil., Ci. E Letras), USP. Bol. v. 85, 1947. 244 p., 1 mapa (Geologia 3).

FREITAS, S. A.; COSTA, M. J. A identidade social do idoso: memória e cultura popular. Conexão UEPG, vol.7, n. 2, 2011.

FRIAÇA, A.; GOUVEIA DAL PINO, E.M.; SODRÉ JR., L.; JATENCO-PEREIRA, V. (Eds.). Astronomia: uma visão geral do universo. São Paulo: EDUSP, 2000. 288pp.

FUNDAÇÃO FLORESTAL. Disponível em:

http://www.ambiente.sp.gov.br/fundacaoflorestal Acesso em 23 nov. 2012.

GARCÍA-CORTÉS, A.; CARCAVILLA URQUÍ, L. C. Documento metodológico para la elaboración del inventario Español de lugares de interés geológico (IELIG). Version 12, 18-05-2009. Instituto Geológico y Minero de España. 2009. Disponível em: http://w.igme.es/ internet/patrimonio/ . Acesso em 20 Mar. 2014

GARDA, G.M. Os Diques Básicos e Ultrabásicos entre as cidades de São Sebastião e Ubatuba, Estado de São Paulo. 1995. $156 \mathrm{f}$ e anexos. Tese de Doutorado, Instituto de Geociências, Universidade de São Paulo, 1995.

GARDA, G.M.; SCHORSCHER, J.H.D. Os diques costeiros básicos e ultrabásicos adjacentes ao Canal de São Sebastião (Litoral Norte do Estado de São Paulo). Revista do IG, v. 17, n.1/2, p.7-31, 1996.

GEOSSIT. Disponível em: http://www.cprm.gov.br/geossit/ . Acesso em 16 set. 2013.

GIL, L.S. Aspectos biológicos do caranguejo Cardisoma guanhumi - (Laitrelle, 1825) (Decapoda, Brachyura, Gecarcinidae) no Núcleo de Picinguaba do Parque Estadual da Serra do Mar, litoral do Estado de São Paulo, Brasil. 2009. 55pp. Tese de mestrado, Instituto de Pesca, Santos, 2009.

GLOBAL GEOPARKS NETWORK. 2013. Member list. Disponível em: http://www.globalgeopark.org/aboutGGN/list/index.htm . Acesso em 16 set. 2013

GRAY, M. Geodiversity: Valuing and Conserving Abiotic Nature. Chichester: John Wiley and Sons, 2004. 434p.

GRAY, M. Geodiversity: the origin and evolution of a paradigm. In: BUREK, C.V. \& PROSSER, C.D. (Ed). The History of Geoconservation. Geological Society Special Publication 300. London: The Geological Society, 2008. 312pp.

GUIA GEOGRÁFICO. Disponível em: http://www.sp-turismo.com/mapas.htm. Acesso em 14 nov. 2010. 
HARTOG, F. Tempo e Patrimonio. Varia História, Belo Horizonte, vol. 22, n.36: 261273, 2006.

HASUI, Y. A grande colisão pré-cambriana do sudeste brasileiro e a estruturação regional Geociências, UNESP, São Paulo, v.29, n.2, p.141-169, 2010.

HASUI, Y.; OLIVEIRA, M.A.D. Província Mantiqueira - Setor Central. In: ALMEIDA, F.F.M.; HASUI, Y. (Eds.) O Precambriano do Brasil, 308-344, 1984.

HASUI, Y.; SADOWSKI, G.R. Evolução geológica do Pré-Cambriano na região sudeste do Estado de São Paulo. Revista Brasileira de Geociências, v.6, n.3, p.182200,1976 .

HEILBRON, M.; PEDROSA SOARES, A. C.; CAMPOS NETO, M. C.; SILVA, L. C.; TROW, R. A. J.; JANASI, V. A. Província Mantiqueira. In: MANTESSO-NETO, V. (Coord.). Geologia do Continente Sul-Americano, São Paulo: Beca, 2004. Cap. XIII, p. 233-242.

HEILBRON, M.; VALERIANO, C.M.; TASSINARI, C.C.G.; ALMEIDA, J.C.H.; TUPINAMBA, M.; SIGA, O.; TROUW, R.A.J. Correlation of Neoproterozoic terranes between the Ribeira Belt, SE Brazil and its African counterpart: comparative tectonic evolution and open questions. In: PANKHURST, R.J.; TROUW, R.A.J.; BRITO NEVES, B.B.; DE WIT, M.J. (Eds) West Gondwana: Pre-Cenozoic Correlations Across the South Atlantic Region. London: Geological Society, Special Publications, v.294, p.211-238, 2008.

HENNIES, W.T.; HASUI, Y. Geocronologia das rochas eruptivas da llha de São Sebastião, SP. In: CONGRESSO BRASILEIRO DE GEOLOGIA, 22, Belo Horizonte, MG. Resumo das Comunicações. Belo Horizonte: SBG, p. 145-148, 1968.

HENNIES, W.T. E HASUI, Y. Contribuição ao reconhecimento da llha de São Sebastião. Simp. Geol. Reg., SBG (São Paulo), v.1, p. 199- 209, 1977.

HERBERT, D.T. Does interpretation help? In: HERBERT, D.T.; PRENTICE, R.C \& THOMAS, C.J. (Ed.). Heritage sites: strategies for marketing and development, Avebury: Aldershot, p.191-230, 1989.

HIGA, K. K. Diques da Ilhabela-SP: Padrão tectônico e divulgação geocientífica. 2011. 59 f. Trabalho de Conclusão de Curso (Geologia). Instituto de Geociências. Universidade de São Paulo, São Paulo, 2011.

HIRUMA, S.T.; RICCOMINI, C.; MODENESI-GAUTTIERI, M.C.; HACKSPACHER, P.C.; NETO, J.C.H.; FRANCO-MAGALHÂES, A.O.B. Denudation history of the Bocaina Plateau, Serra do Mar, southeastern Brazil: Relationships to Gondwana breakup and passive margin development. Gondwana Research, v.18, p.674-687, 2010.

HOSE T.A. Geotourism - Selling the Earth to Europe. In: MARINOS, P.G.;

KOUKIS, G.C.; TSIAMBAOS, G.C.; STOURNARAS, G.C. (Eds.) Engineering Geology and the Environment. Rotterdam: A.A. Balkema. pp.2955-2960, 1997. 
HOSE, T.A. Geological interpretation and geoconservation promotion for tourists. In: BARRETINO, D.; WIMBLEDON, W.A.P.; GALLEGO, E. (Ed.). Geological heritage: its conservation and management. Madrid: Sociedad Geologica de España, Instituto Tecnologico GeoMinero de España/ ProGEO, p.127-146, 2000.

ICMBIO - Instituto Chico Mendes de Conservação da Biodiversidade. Disponível em: http://www.icmbio.gov.br/portal/ . Acesso em 18/11/2012.

ILHABELA. Disponível em: http://www.ilhabela.com.br/ilhabela/ . Acesso em 02 out. 2012.

IPT - INSTITUTO DE PESQUISAS TECNOLÓGICAS DO ESTADO DE SÃO PAULO. Mapa geológico do Estado de São Paulo; escala 1:500.000. v.1 (texto) e v.2 (mapa). Governo do estado de São Paulo. Secretaria da Indústria, Comércio, Ciência e Tecnologia, 1981.

LEEMING, D.A. The Oxford companion to world mythology. Oxford: Oxford University Press. 2005. 512p.

LIMA, F.L. Proposta metodológica para a inventariação do patrimônio geológico brasileiro. 2008. 91 p. Dissertação de Mestrado. Escola de Ciências da Universidade do Minho, Portugal. 2008.

LIMA, F.L.; BRILHA, J.B.; SALAMUNI, E. Inventorying Geological Heritage in Large Territories: A Methodological Proposal Applied to Brazil. Geoheritage. v.2, p. 91-99, 2010.

LIMA, G.A. Gabros estratiformes da região norte da llha de São Sebastião, SP. 2001. 170 pp. Dissertação de Mestrado, Instituto de Geociências, Universidade de São Paulo, 2001.

LIMA, G.A. \& SCHORSCHER, H.D. Complexo gábrico estratiforme da Ponta da Pacuíba - Ilha de São Sebastião- SP. VI Simpósio de Geologia do Sudeste, São Pedro. Boletim de Resumos, p.65, 1999.

LIMA, S.F. Introdução ao Conceito de Sustentabilidade: aplicabilidade e limites. Cadernos da Escola de Negócios da UniBrasil, v.4, p. 20-24, 2009.

LOURENÇO, T. S. Variabilidade interanual do clima de ondas e sua influência no litoral sudeste e sul do Brasil. 2012. 103 p. Dissertação de Mestrado - Instituto Oceanográfico, Universidade de São Paulo, São Paulo, 2012.

LUPO, F.; BORTOLUSSO, M. Viagens ecológicas e culturais, vol. 2 - Ilhabela: Photoverde, 2012.194pp.

MACKENZIE, D. Boom and doom: revisiting prophecies of collapse. New Scientist Magazine, v. 2846, p. 38-41, 2012. 
MAFFRA, C.Q.T. Geologia estrutural do embasamento cristalino na região de São Sebastião, SP: evidências de um domínio transpressivo. 2000. 113p. Dissertação de Mestrado, Instituto de Geociências, USP, 2000.

MANSUR, K. L.; FREITAS, P. L.; TALARICO, T. E.; CAPECHE, C. L.; GUEDES, E.; GUIMARÃES, P. V.; MEDEIROS, F. Projeto Caminhos Geológicos nas escolas: o caso de São José de Ubá - RJ. In: SIMPÓSIO DE GEOLOGIA DO SUDESTE, 9., Niterói, 2005. Anais... Niterói: Sociedade Brasileira de Geologia, 2005, p. 207.

MANSUR, K.L. Diretrizes para Geoconservação do Patrimônio Geológico do Estado do Rio de Janeiro. O caso do Domínio Tectônico Cabo Frio. 2010. v.1: 214 p., v.2: anexos. Tese de Doutorado. Universidade Federal do Rio de Janeiro. 2010.

MARQUES, L.S.; ERNESTO, M. O magmatismo toleítico da Bacia do Paraná. In: MANTESSO-NETO, V.; BARTORELLI, A.; CARNEIRO, C.D.R.; BRITO NEVES, B.B. (Eds.). Geologia do continente sul-americano: evolução da obra de Fernando Flávio Marques de Almeida. São Paulo: Beca, 2004, pp. 245-263.

MERLO, M. Entre o mar e a mata: a memória afro-brasileira, São Sebastião, llhabela e Ubatuba. São Paulo: PUCSP, EDUC., 2005. 301pp.

MILTON, K. Loving Nature: towards an ecology of emotion. London: Routledge, 2002. 182pp.

MITHEN, S. A Pré-História da mente: uma busca das origens da arte, da religião e da ciência. São Paulo: Editora UNESP, 2002.

MOREIRA, J.C. Interpretação ambiental, aspectos geológicos e geomorfológicos. Bol. geogr., Maringá, v. 30, n. 2, p. 87-98, 2012.

MOTOKI, A.; SOARES, R.; SICHEL, S.E.; AIRES, J.R.; LOBATO, M. Feições intempéricas em rochas alcalinas félsicas de Nova Iguaçu, RJ. Revista Escola de Minas, v. 60, n. 3, p. 451-458, 2007.

MOTOKI, A.; PETRAKIS, G.H.; SICHEL, S.E.; CARDOSO, C.E.; MELO, R.C.; SOARES, R.; MOTOKI, K.F. Origem dos relevos do maciço sienítico do Mendanha, RJ, com base nas análises geomorfológicas e sua relação com a hipótese do vulcão de Nova Iguaçu. Geociênc. (São Paulo), São Paulo, v. 27, n. 1, Jan. 2008.

NASA. Earth Fact Sheet. Disponível em:

http://nssdc.gsfc.nasa.gov/planetary/factsheet/earthfact.html. Acesso em 20 set 2012.

NIKITINA, N. Geodiversity, and the geoethical principles for its preservation. Annals of Geophysics. v.55, n. 3, p.497 - 500, 2012.

OLIVEIRA, S.C.F.; SANTOS, G.L.G. Construção sócio-histórica e midiática da velhice. Revista Brasileira de Ciências do Envelhecimento Humano, v. 6, n. 3, 2009. 
PARANÁ. Diretrizes Curriculares de Educação Básica (DCEs) - Geografia. Paraná, 2008.

PElb - Parque Estadual de llhabela - Hotsite. Disponível em:

http://www.fflorestal.sp.gov.br/hotsites/hotsite/sobre.php . Acesso em 24 nov. 2012.

PEMBERTON, M. Conserving geodiversity: the importance of valuing our geological heritage. Paper presented to the Geological Society of Australia National Conference, 2001.

PEREIRA, R. F., BRILHA, J. ; MARTINEZ, J. E. Proposta de enquadramento da geoconservação na legislação ambiental brasileira. Memórias e Notícias: Revista Cient. do Dept. de Ciências da Terra e do Museu Mineralógico e Geológico da Universidade de Coimbra. Coimbra, v.3, p. 491- 499, 2008.

PEREIRA, R.G.F.A. Geoconservação e desenvolvimento sustentável na Chapada Diamantina (Bahia - Brasil). 2010. 295p. Tese de doutorado. Escola de Ciências da Universidade do Minho (Portugal). 2010.

PEREIRA, P. J. S. Patrimônio Geomorfológico: conceptualização, avaliação e divulgação. Aplicação ao Parque Natural de Montesinho. 2006. 370 pp. Tese de Doutoramento em Ciências. Escola de Ciências da Universidade do Minho. 2006.

PERROTTA, M. M. et al. Mapa Geológico do Estado de São Paulo, escala 1:750.000. São Paulo: CPRM, 2005. (Programa Levantamentos Geológicos Básicos do Brasil).

PETRAKIS, G.H.; MOTOKI, A.; SICHEL, S.E.; ZUCCO, L.L.; AIRES, J.R.; MELLO, S.L.M. Geologia de jazidas de brita e areia artificial de qualidade especial: exemplos do álcali sienito de Nova Iguaçu, RJ, e riolito de Nova Prata, RS. Geociênc. (São Paulo), São Paulo, v. 29, n. 1, 2010.

PIANCA, C.; MAZZINI, P. L. F.; SIEGLE, E. Brazilian offshore wave climate based on NWW3 reanalysis. Brazilian Journal of Oceanography, v. 58, n.1, p.53-70, 2010.

PRALONG, J.P. A method for assessing tourist potential and use of geomorphological sites. Géomorphologie: relief, processus, environment. v. 3, p.189196, 2005.

PREFEITURA DE ILHABELA. Disponível em: http://www.ilhabela.sp.gov.br/ Acesso em 12 nov. 2012

RAPOSO, M.I.B.; D'AGRELLA-FILHO, M.S.; PINESE, J.P.P. Magnetic fabrics and rock magnetism of Archaean and Proterozoic dike swarms in the Southern São Francisco craton, Brazil. Tectonophysics, v. 443, p. 53-71, 2007.

RICCOMINI, C. O Rift Continental do Sudeste do Brasil. São Paulo, 1990. 256p. Tese de Doutorado. Instituto de Geociências, Universidade de São Paulo, 1990. 
RICCOMINI, C. Tectonismo gerador e deformador dos depósitos sedimentares pósgondvânicos da porção centro-oriental do estado de São Paulo e áreas vizinhas. Tese de Livre-docência. 1995. Instituto de Geociências Universidade de São Paulo, IG-USP.

RICCOMINI, C.; SANT'ANNA, L.G. \& FERRARI, A.L. Evolução geológica do Rift Continental do Sudeste do Brasil. In: MANTESSO-NETO, V.; BARTORELLI, A.; DAL RÉ CARNEIRO, C. \& BRITO NEVES, B.B. (Org.). Geologia do Continente SulAmericano - Evolução da Obra de Fernando Flávio Marques de Almeida. Beca, 2004. p. 383-405.

RICCOMINI, C.; VELÁZQUEZ, V.F.; GOMES, C.B. Tectonic controls of the Mesozoic and Cenozoic alkaline magmatism in central-southeastern Brazilian platform. In: CHIARAMONTI, P.C.; GOMES, C.B (Eds.) Mesozoic to Cenozoic alkaline magmatism in the Brazilian platform. São Paulo: EDUSP, 2005.

RIVAS, V.; RIX, K.; FRANÉS, E.; CENDERO, A.; BRUNSDEN, D. Geomorphological indicators for environmental impact assessment: consumable and non-consumable geomorphological resources. Geomorphology, v. 18, p.169-182, 1997.

SADOWSKI, G.R. A megafalha de Cubatão no sudeste brasileiro. Bol. IG-USP. Serie Científica, v. 22, p.15-28, 1991.

SARNA, N.M. The Mists of Time: Genesis I-II. In: FEYERICK, A. Genesis: World of Myths and Patriarchs. NYU Press. 1997. 560pp.

SATO, E.N. Petrografia e geocronologia U/Pb (TIMS) de rochas alcalinas da llha de São Sebastião (SP). 2006. 61pp. Trabalho de Conclusão de Curso. Instituto de Geociências, Universidade de São Paulo, 2006.

SCHMIDT, M.A.; CAINELLI, M. Ensinar história. São Paulo: Scipione, 2004. (Pensamento e ação no magistério)

SCHOBBENHAUS, C.; BRITO NEVES, B. B. A geologia do Brasil no contexto da plataforma sulamericana. In: BIZZI, L. A.; SCHOBBENHAUS, C.; VIDOTTI, R. M.; GONÇALVES, J. H. (Ed.) Geologia, Tectônica e Recursos Minerais do Brasil CPRM, Brasília. 2003. 692p.

SCHOBBENHAUS, C.; SILVA, C.R. (Org.). Geoparques do Brasil: propostas. Brasilia: CPRM, 2012. 745pp.

SCHORSCHER, J. H. D.; LIMA, G A. Gabros estratiformes da região norte da llha de São Sebastião, SP, Brasil. In: $7^{\circ}$ Simpósio de Geologia do Nordeste, 2001, Rio de Janeiro. Boletins de Resumos - $7^{0}$ Simpósio de Geologia do Nordeste. Rio de Janeiro: SBG, 2001. p. 75-75.

SERRANO, E. \& GONZALEZ TRUEBA, J. J. Assessment of geomorphosites in natural protected areas: the Picos de Europa National Park (Spain). Géomorphologie: relief, processus, environment, v.3, p.197-208, 2005. 
SHARPLES, C. 2002. Concepts and Principles of Geoconservation. Tasmanian Parks \& Wildlife Service. Disponível em:

http://www.dpiw.tas.gov.au/inter.nsf/Attachments/SJON-

57W3YM/\$FILE/geoconservation.pdf. Acesso em 15 set. 2012

SIGEP - Comissão Brasileira de Sítios Geológicos e Paleobiológicos. Disponível em: http://sigep.cprm.gov.br/ . Acesso em 17 set. 2013

SILVA, R.C. (Ed.). Geodiversidade do Brasil: conhecer o passado, para entender o presente e prever o futuro. Rio de Janeiro: CPRM - Serviço Geológico do Brasil, 2008. 264pp.

SILVA, T.T.; RICCOMINI, C. O uso de corpos intrusivos como indicadores tectônicos: o enxame de diques Santos - Rio de Janeiro. In: 13ํㅗ Simpósio Internacional de Iniciação Científica da USP. São Carlos, SP. 2005.

SIMÕES, N. Uma viagem pela história do arquipélago de Ilhabela. São Paulo: Noovha America, 2005. 86pp.

SIQUEIRA, R.L.; BOTELHO, M.I.V.; COELHO, F.M.G. A velhice: algumas considerações teóricas e conceituais. Ciência \& Saúde Coletiva, Rio de Janeiro, v.7, n.4, p.899 - 906, 2002.

SONOKI, LK. ; GARDA, G.M. Idades K-Ar de rochas alcalinas do Brasil meridional e Paraguai oriental: compilação e adaptação às novas constantes de decaimento. Boletim IG-USP, Série Científica, v.19, p.63-85, 1988.

SOUZA, C.R. de G. Mapeamento de compartimentos fisiográficos de planície costeira e baixa encosta e da vegetação associada, no litoral norte de São Paulo. In: UGB, SIMPÓSIO NACIONAL DE GEOMORFOLOGIA, 6, 2006, Goiânia, Anais, CDROM.

STANLEY, M. Welcome to the 21st century. Geodiversity Update, v. 1, p.1-8, 2001.

STANLEY, M. Geodiversity - linking people, landscapes and their culture. In:

PARKES, M. (Ed). Natural and Cultural Landscapes - the Geological Foundation. Dublin: Royal Irish Academy, p.45-52, 2002.

SUGUIO, K. Tópicos de geociências para o desenvolvimento sustentável: as regiões litorâneas. Geol. USP, Sér. didát., v.2, São Paulo, fev. 2003.

TASSINARI, C.C.G. As idades das rochas e dos eventos metamórficos da porção sudeste do Estado de São Paulo e sua evolução crustal. 1988. 263p. Tese de doutorado. Instituto de Geociências, USP, São Paulo, 1988.

THOMAS, K. O Homem e o Mundo Natural: Mudanças de Atitude em Relação às Plantas e aos Animais (1500-1800). Trad. de João Roberto Martins Filho; São Paulo: Companhia das Letras, 1989. 544pp. 
TILDEN, E. Interpreting our heritage. Chapel Hill, NC: University of North Carolina. 3rd ed. 1977

TROMPETTE, R.; EGYDIO-SILVA, M.; TOMMASI, A.; VAUCHEZ, A.; UHLEIN, A. Amalgamação do gondwana ocidental no panafricano-brasiliano e o papel da geometria do cráton do São Francisco na arquitetura da Faixa Ribeira. Revista Brasileira de Geociências, v.23, n.3, p. 187-193, 1993.

TROUW, R.A.J.; HEILBRON, M.; RIBEIRO, A.; PACIULLO, F.V.P.; VALERIANO, C.M.; ALMEIDA, J.C.H.; TUPINAMBÁ, M.; ANDREIS, R.R. The central segment of the Ribeira Belt. In: CORDANI, U.G.; MILANI, E.J.; THOMAZ FILHO, A. (Ed.) Tectonic Evolution of South America, p. 287-310. 2000.

UCEDA, A.C. Patrimonio geológico; diagnóstico, clasificación y valoración. In: Suárez-Valgrande, J.P (Ed.) Jornadas sobre Património Geológico y Desarrollo Sostenible, Serie Monografías, Ministério de Medio Ambiente de España, p. 23-37, 2000.

ULBRICH, H.H.G.J. \& GOMES, C.B. Alkaline rocks from continental Brazil. Earth Science Reviews, v.17, p.135-154, 1981.

UN - United Nations. Report of the World Commission on Environment and Development: Our Common Future. 1987. Disponível em: http://www.undocuments.net/wced-ocf.htm. Acesso em 03 out. 2012

UNEP - United Nations Environmental Programme.1972. Declaration of the United Nations Conference on the Human Environment. Disponível em:

http://www.unep.org/Documents.Multilingual/Default.asp?DocumentID=97\&ArticlelD= $\underline{1502 \& \mathrm{l}=\mathrm{en}}$. Acesso em 03 out. 2012

UNESCO - Text of the Convention for the Safeguarding of Intangible Cultural Heritage. 2003. Disponível em: http://www.unesco.org/culture/ich/en/convention

Acesso em 20 abr. 2014

USGS - The US Geological Service Water Science School. How much water is there on, in and above the Earth? Disponível em:

http://ga.water.usgs.gov/edu/earthhowmuch.html. Acesso em 20 set. 2012

VASCONCELOS, J.M.O. Interpretação e manejo de trilhas. In: MITRAUD, S. (org). Manual de Ecoturismo de Base Comunitária: ferramentas para um planejamento responsável. WWF Brasil, 2003. 470p.

ZALÁN, P.V. Evolução fanerozóica das bacias sedimentares brasileiras. In: MANTESSO-NETO, V. (Coord.): Geologia do Continente Sul-Americano, São Paulo: Beca, 2004. Cap. XXXIII.

ZALÁN, P.V. \& OLIVEIRA, J. A. B. Origem e evolução estrutural do sistema de riftes cenozóicos do sudeste do Brasil. Boletim de Geociências da Petrobras, v.13, n. 2, p.269-300, 2005. 
ZOUROS, N. C. Geomorphosite assessment and management in protected areas of Greece. Case study of the Lesvos island-coastal geomorphosites. Geographica Helvetica: Swiss Journal of Geography. v.3, p.169-180, 2007. 